\title{
Geographic distribution of tree species diversity of the United States reveals positive association between biodiversity and site productivity
}

James V. Watson

West Virginia University

Follow this and additional works at: https://researchrepository.wvu.edu/etd

\section{Recommended Citation}

Watson, James V., "Geographic distribution of tree species diversity of the United States reveals positive association between biodiversity and site productivity" (2014). Graduate Theses, Dissertations, and Problem Reports. 558.

https://researchrepository.wvu.edu/etd/558

This Thesis is protected by copyright and/or related rights. It has been brought to you by the The Research Repository @ WVU with permission from the rights-holder(s). You are free to use this Thesis in any way that is permitted by the copyright and related rights legislation that applies to your use. For other uses you must obtain permission from the rights-holder(s) directly, unless additional rights are indicated by a Creative Commons license in the record and/ or on the work itself. This Thesis has been accepted for inclusion in WVU Graduate Theses, Dissertations, and Problem Reports collection by an authorized administrator of The Research Repository @ WVU. For more information, please contact researchrepository@mail.wvu.edu. 


\title{
GEOGRAPHIC DISTRIBUTION OF TREE SPECIES DIVERSITY OF THE UNITED STATES REVEALS POSITIVE ASSOCIATION BETWEEN BIODIVERSITY AND SITE PRODUCTIVITY
}

\author{
James V. Watson
}

Thesis submitted to the Davis College of Agriculture, Natural Resources and Design at West Virginia University
In partial fulfillment of the requirements for the degree of
Master of Science in Forestry

Dr. Jingjing Liang, Ph.D., Chair

Dr. Patrick C. Tobin, Ph.D.

Dr. James S. Rentch, Ph.D.

Division of Forestry and Natural Resources

Morgantown, West Virginia 2013

Keywords: tree species diversity, forest management, biological conservation, large-scale mapping, timber 


\title{
Abstract \\ GEOGRAPHIC DISTRIBUTION OF TREE SPECIES DIVERSITY OF THE UNITED STATES REVEALS POSITIVE ASSOCIATION BETWEEN BIODIVERSITY AND SITE PRODUCTIVITY
}

\begin{abstract}
James V. Watson
With the loss of species worldwide due to anthropogenic factors, especially in forested ecosystems, it has become more urgent than ever to understand the biodiversity-ecosystem functioning relationship (BEFR). BEFR research in forested ecosystems is very limited and thus studies that incorporate greater geographic coverage and structural complexity are much needed. Here, I compiled ground-measured data from 436,177 Forest Inventory and Analysis (FIA) plots of every U.S. state except Hawaii to map current basal area, site productivity, and tree species diversity across the United States. Based on these point-data maps, I investigated the relationship between forest productivity and tree species diversity. Out of 15 forest types, 13 show a positive association between diversity and productivity, and only two show insignificant or negative relationships. The large number of ground-measured plots, as well as the magnitude of geographic scale, rendered overwhelming evidence in support of a positive tree species diversity-timber productivity relationship. This empirical evidence provides insights to forest management and biological conservation that are of a much broader applicability than controlled experiments in terms of both forest type and geographic scale. The findings imply that timber productivity across the United States may be impaired by the loss of species in forested ecosystems, and that biological conservation, due to its potential benefits on maintaining productivity, can have profound impacts on the availability of selected services from forested ecosystems.
\end{abstract}




\section{Table of Contents}

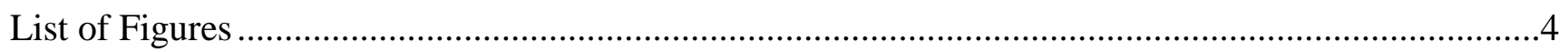

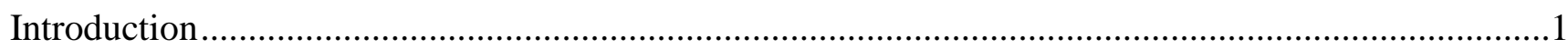

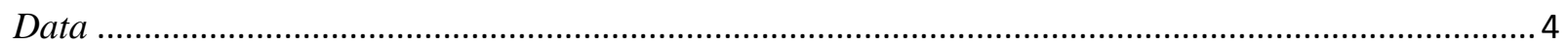

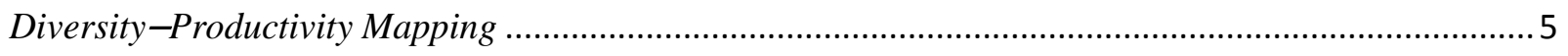

Diversity-Productivity Relationship ........................................................................................ 9

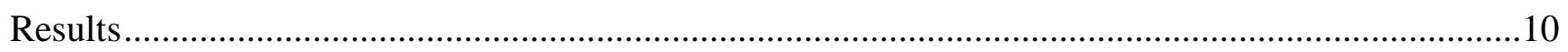

Geographic Distribution of Tree Species Richness, Forest Productivity and Stocking........................ 10

Diversity-Productivity Relationship............................................................................................ 11

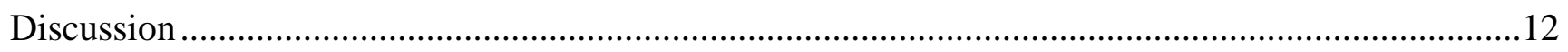

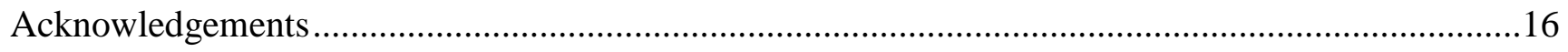

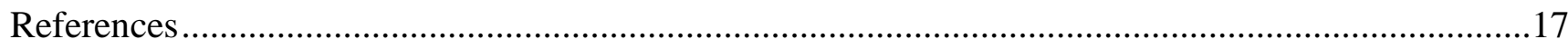

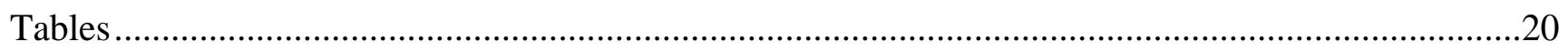

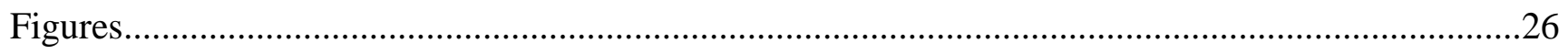

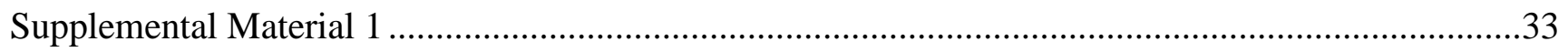

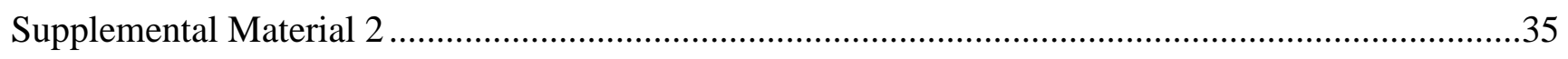




\section{List of Figures}

Figure 1. Richness of woody plant species across the 48 contiguous U.S. states and Alaska, derived from FIA ground measurements completed between 1968 and 2011. GCS_WGS_1984 projection for the main map and Alaska Albers Equal Area Conic projection for the inset.

Figure 2. Total forest stand basal area $\left(\mathrm{m}^{2} \mathrm{ha}^{-1}\right)$ across the 48 contiguous U.S. states and Alaska, derived from FIA ground measurements completed between 1968 and 2011. GCS_WGS_1984 projection for the main map and Alaska Albers Equal Area Conic projection for the inset.

Figure 3. Forest types across the 48 contiguous U.S. states and Alaska, derived from both a forest type group map of the contiguous United States and a forest type group map of Alaska. Both of these maps were remakes from Ruefenacht et al. (2008) using FIA point data. GCS_WGS_1984 projection for the main map and Alaska Albers Equal Area Conic projection for the inset.

Figure 4. Site productivity class codes (1 through 7) and continuous values of site productivity estimated by the site productivity model (Eq. 2).

Figure 5. Forest productivity $\left(\mathrm{m}^{3} \mathrm{ha}^{-1} \mathrm{year}^{-1}\right)$ across the 48 contiguous U.S. states and Alaska, derived from FIA ground measurements completed between 1968 and 2011. GCS_WGS_1984 projection for the main map and Alaska Albers Equal Area Conic projection for the inset.

Figure 6. Time of inventory for all the FIA plots across the 48 contiguous U.S. states and Alaska. GCS_WGS_1984 projection for the main map and Alaska Albers Equal Area Conic projection for the inset.

Figure 7. Sensitivity of stand productivity $\left(\mathrm{m}^{3} \mathrm{ha}^{-1} \mathrm{year}^{-1}\right)$ to species richness for 15 forest types across the 48 contiguous U.S. states and Alaska, with stand basal area being kept constant at its sample mean. 


\section{Introduction}

Over the past two decades, there has been an extensive discussion over the biodiversity-ecosystem functioning relationship (BEFR). The loss of biodiversity can greatly alter the characteristics and functioning of an ecosystem, including its productivity and services to human-beings (Hooper et al. 2005). With the loss of species worldwide due to anthropogenic factors, climatic disturbance, and biological invasions, etc. (Fleming et al. 2011), it has become more urgent than ever to understand the BEFR (Symstad et al. 2003).

There is increasing evidence that supports a positive BEFR, which indicates that the loss of biodiversity affects the functioning of an ecosystem (Cardinale et al. 2012; Hooper et al. 2005; Loreau et al. 2001; Naeem et al. 2012). There are several mechanisms which are thought to be the reason for a positive BEFR. It is thought that complementarity is one reason for a positive BEFR. Complementarity includes ecosystem processes such as niche differentiation (process by which different species utilize different resources and thus don't compete for the same resources) and species facilitation (process where one species has some characteristic that benefits another species, but there is no negative result to either species) (Loreau, 2001 \#79). Another reason for a positive BEFRR is that biodiversity acts as insurance against disturbance or change in the ecosystem since having a diverse species composition will ensure that not all species react similarly to the change the ecosystem is faced with (Loreau, 2001 \#79). Stochastic processes are also a reason for a positive BEFR. Applying stochastic processes to ecosystem functioning, the chance that a forest contains a more productive species increases with increasing species diversity (Loreau, 2001 \#80). 
Most existing evidence of a positive BEFR comes from grassland experiments at limited spatial scales (Cardinale et al. 2012; Loreau et al. 2001; Symstad et al. 2003). Since these experiments fail to include some key processes inherent to natural ecosystems, such as the introduction of new species, decomposition of woody plant material, and the utilization of water by woody tree species, it is difficult to extrapolate the results to greater temporal and spatial scales (Symstad et al. 2003).

BEFR studies in forested ecosystems are especially limited (Liang et al. 2007; Paquette and Messier 2011; Zhang et al. 2012), primarily due to the complexity of forested ecosystems and the length of time it takes to derive estimates of growth and productivity. While the majority of studies confirm a positive relationship between tree diversity and ecosystem productivity and services (Caspersen and Pacala 2001; Gamfeldt et al. 2013; Kelty 1989; Lei et al. 2009; Liang et al. 2005; Liang et al. 2007; Paquette and Messier 2011; Young et al. 2011; Zhang et al. 2012), some argue otherwise (Chen et al. 2003; Vilà et al. 2003). BEFR also plays an important role in the management of forest resources. A traditional view in silviculture is that clearcutting with artificial regeneration (even-aged monoculture) optimizes forest productivity (e.g. Assmann 1970), but it has been found that this maxim does not generalize (Haight and Monserud 1990; Hasse and Ek 1981) and that the mixed-species stands could have higher long-term productivity (e.g. Buongiorno et al. 1995; Haight and Monserud 1990; Liang et al. 2005; Liang et al. 2006). Most biodiversity studies in forested ecosystems have primarily used even-aged designs that lack structure complexity of natural uneven-aged forests (Leuschner et al. 2009). Thus, studies that incorporate greater geographic coverage and structural complexity are much needed for analyzing the BEFR in forested ecosystems. 
Biodiversity studies of forested ecosystems, especially at larger geographic scales, are not only of great value to BEFR research, but also of strategic importance to the world's energy security and economic development. Tree species provide an essential source of energy and financial income worldwide, especially for rural areas where livelihoods depend heavily on forest resources (FAO 2012).

The limited maps of biodiversity across the world's forested ecosystems were developed using either raster data or point data. Biodiversity maps of raster data (Hernández-Stefanoni and Dupuy 2007; Hernandez-Stefanoni and Ponce-Hernandez 2006; Kreft and Jetz 2007; Liang 2012; Ricketts 1999) are mostly based on a combination of ground measurements, remote sensing data, and spatial estimation. As variance is ignored within a raster, such maps have limited value to BEFR studies. Maps showing distribution of biodiversity, consisting of point data are the most valuable, because spatially explicit biodiversity records can be matched with the forest productivity data at the same locations for the study of BEFR. Unfortunately, due to the cost of ground measurements, biodiversity maps of point data are extremely limited across the world (Köble and Seufert 2001) and there are none at a national scale for the United States.

The primary objective of this study is to investigate the relationship between diversity of tree species and productivity-the potential timber growth a stand is capable of sustaining-throughout various types of temperate forests across the United States. An interesting component of this project is that the BEFR is analyzed individually for 15 forest types found across the United States. The study area consisted of the 48 contiguous states and the State of Alaska, and the data I used in this study come from field-measured tree and site attributes from 
436,177 USDA Forest Service Forest Inventory Analysis (FIA) permanent sample plots distributed across the United States.

The secondary objective was to synthesize ground-measured data in mapping tree species richness over all types of temperate forests across the United States. In addition, I also created maps of forest stocking and productivity based on FIA data for the same 436,177 FIA plots across the country to derive the relationship between biodiversity and forest productivity.

\section{Materials and Methods}

\section{Data}

Data for this study came from two sources-FIA (Woudenberg et al. 2011) and the Digital Elevation Model (DEM) of the contiguous United States and Alaska (Gesch et al. 2002)

The FIA databases are a product of the United States Department of Agriculture (USDA), Forest Service FIA Program, which has established a network of permanent sample plots across the United States to determine the extent and status of the nation's forests in regard to the condition, volume, growth, and depletions (Woudenberg et al. 2011). The FIA ground-based inventories have been conducted at different time periods by states, ranging from the 1960 s to 2012. Following the passage of the 1998 Farm Bill (Gillespie 1999), the FIA program in the new millennium switched from a periodic inventory system to an annual system in which a portion of the FIA plots in each state would be remeasured each year (Gillespie 1999).

The FIA program uses a 3-phase sampling scheme (Woudenberg et al. 2011). Phase 1 uses stratification to aggregate ground samples into groups to minimize variance using stratified estimation. Every FIA ground plot is assigned to a stratum of which a weight is based on its proportion within the estimation unit. Each stratum within an estimation unit has an expansion 
factor that is calculated as the product of stratum weight and total area divided by the amount of phase 2 plots within the stratum. Phase 2 consists of actual FIA ground plots, which follow a national standard and are fixed-radius plots $0.40 \mathrm{ha}$ in size. To protect the privacy of landowners, geographic coordinates of FIA ground plots are "fuzzed" (Lister et al. 2002). The true plot locations are known to be within $1.61 \mathrm{~km}$ of the fuzzed values under the periodic system, and $0.80 \mathrm{~km}$ under the current plot design that was first used in the 1990s for the last of the periodic inventories and all of the current annual inventories (Woudenberg et al. 2011). The ramifications of using the fuzzed coordinates instead of real ones are provided in the discussion.

In the current FIA plot design, each permanent sample plot consists of four 0.02-ha subplots $7.32 \mathrm{~m}$ in radius (see Fig. 1 in the Supplemental Material). Subplots 2, 3, and 4 are situated around subplot 1 in a triangular pattern, with a $36.58 \mathrm{~m}$ distance between the plot centers of subplots 2, 3, and 4 and the center of subplot 1 (Bechtold and Scott 2005). On a subplot, all trees greater than or equal to $12.70 \mathrm{~cm}$ in diameter at breast height (dbh) are measured. A $2.07-\mathrm{m}$ radius microplot is located inside of each of the 4 subplots, in which all trees with a dbh smaller than $12.70 \mathrm{~cm}$ are tagged and measured.

FIA inventories are designed in a way such that state level sampling errors are met at the $67 \%$ confidence limit (Woudenberg et al. 2011). Sampling error is kept $\leq 3 \%$ for every 404,686 ha of timberland. It should be noted that despite the mandated sampling error to the area, the sampling errors applied to removals, volume, and total annual growth are targeted by the FIA program, which is $5 \%$ for every $3 \times 10^{7} \mathrm{~m}^{3}$ of growing stock on timberland for the eastern United States and $10 \%$ for every $3 \times 10^{7} \mathrm{~m}^{3}$ for the western United States.

\section{Diversity-Productivity Mapping}


To study the forest productivity, stocking, and species diversity across the United States, I first compiled state and regional FIA databases that I obtained from different FIA regional offices into one nationwide master database (hereafter, master database). Using SQL queries of the Microsoft Access program, I first extracted values of 12 key attributes from individual state and regional FIA databases-plot number, tree species, dbh, tree status, trees per unit area that a sample tree represents, elevation, slope, forest type, site productivity class, latitude, longitude, and inventory year. The key attributes, which were used to develop the seven final variables used in this study (Table 1), were all directly measured in the field, with an exception of forest type, which was assigned based on the plot location and the forest type map across the contiguous United States and Alaska at a 250-m spatial resolution (Ruefenacht et al. 2008). I only selected these 12 key attributes for the master database because 1) these attributes are essential for deriving forest productivity, basal area, and tree species diversity that were used in our study; 2) all individual state and regional databases have these attributes; and 3) all the redundant or unused attributes from individual databases were deleted to keep the master database within our computation and storage capacity. After removing inconsistent, missing, and apparently erroneous entries, the final master database consisted of 436,177 permanent sample plots distributed across the contiguous United States and Alaska.

Tree species diversity $(N)$, in terms of species richness, was derived from the predesignated numeric codes named "SPCD" that identifies species of every single tree in the FIA databases (Woudenberg et al. 2011). $N$ represents the number of species among all the live trees on a permanent sample plot and across the United States, and $N$ ranges from 1 to 24 (Table 2, Fig. 1). 
Basal area $(B)$, the total cross sectional area of all the live trees on a permanent sample plot, was derived from the FIA attributes dbh, tree status (ST), and trees per unit area (TPA) that a sample tree represents according to:

$$
B=\frac{\sum 3.14 \cdot d b h_{S T=1}^{2} \cdot T P A}{4}
$$

where tree status is a field recorded code defining the status of a tree: 0 indicates no status, 1 live, 2 dead, and 3 indicates a tree that has been removed (Woudenberg et al. 2011). Over the contiguous United States and Alaska, $B$ ranges from 0 to $188.99 \mathrm{~m}^{2} \mathrm{ha}^{-1}$, with the highest forest stocking values concentrated in the western United States and Central Appalachia (Table 2, Fig. 2)

The data for elevation $(E)$ and slope $(S)$, which were only used to develop a continuous measure of site productivity based on site class (see Eq. 2 below), were mostly obtained from the ground-measured FIA databases. However, $70 \%$ of FIA plots in the master database are missing elevation records and 5.6\% are missing slope records. To retain these plots for the estimation of site productivity, especially for those forest types with a relatively small sample size (e.g. tropical and exotic hardwoods have only 408 plots and western hardwoods 1,924 plots), I derived the missing data from the plot coordinates and the DEM of the United States. For the elevation, $70 \%$ of data were derived from the DEM of the United States, and $30 \%$ from the FIA databases. For the slope, $5.6 \%$ of data came from the United States DEM and $94.4 \%$ from the FIA databases. The DEM of the contiguous United States (30-m resolution) and Alaska (60-m resolution) was downloaded from the Geospatial Data Gateway site (http://datagateway.nrcs.usda.gov/, last accessed February 20, 2014). 
The forest type map across the contiguous United States and Alaska was developed by Ruefenacht et al. (2008) based on the FIA data. The map has a 250-m spatial resolution, with an accuracy of $\approx 69 \%$ for the 48 contiguous U.S. states, and $\approx 78 \%$ for Alaska. For simplicity, in this study, I grouped some of the original forest types together based on similar geographic location and species composition to reduce the total number of forest types from 30 to 15 (Fig 3).

Site productivity $(C)$, a measure of the potential timber growth that a plot is capable of sustaining, was derived from a categorical attribute from the FIA databases named "SITECLCD" which ranks site productivity in a hierarchical order from one to seven. Each code of SITECLCD denotes a range of productivity: 1 stands for the most productive sites with a mean annual increment (MAI, see Hanson et al. 2003) greater than or equal to $15.74 \mathrm{~m}^{3} \mathrm{ha}^{-1} \mathrm{yr}^{-1} ; 2$ for $11.55-15.74 ; 3$ for $8.40-11.55 ; 4$ for $5.95-8.40,5$ for $3.50-5.95,6$ for $1.40-3.50$, and 7 for the least productivity sites with a MAI less than $1.40 \mathrm{~m}^{3} \mathrm{ha}^{-1} \mathrm{yr}^{-1}$ (Woudenberg et al. 2011). I converted the categorical attribute of SITECLCD to a continuous attribute of site productivity $(C)$ by accounting for the effects of elevation and slope with a linear model:

$C=\alpha_{0}+\alpha_{1} \cdot S I T E C L C D+\alpha_{2} \cdot E+\alpha_{3} \cdot S$

where $\alpha_{0}$ through $\alpha_{3}$ were coefficients to be estimated by ordinary least squares (OLS). This model was based on previous findings that elevation and slope both have a profound impact on the productivity of forest sites (Stage and Salas 2007 and references therein). The model was calibrated with FIA data from the entire country by fitting observed values of SITECLCD, E, and $S$ of each permanent sample plot against the mid-point values of MAI that corresponds to the SITECLCD value of that plot. The model was examined for the level of significance of the coefficients, the biological interpretation, and the normality of residual pattern (Table 3). Then, I 
estimated the actual site productivity of each of the 436,177 FIA plots using the values of SITECLCD, E, and $S$ of that plot in Eq. 2, thereby making the site productivity of FIA plots a continuous variable with higher accuracy across the country (Fig. 4).

I created the master database to produce nationwide maps of forest stocking (basal area, Fig. 2), treespecies richness (Fig. 1), site productivity (Fig. 5), and year of plot inventory (Fig. 6). For the creation of each of these maps, two separate data layers were developed; one for Alaska and one for the contiguous United States. Each plot represents a raster with size 0.05 for the contiguous United States and size 0.2 for Alaska. The GCS-WGS-1984 projection was used for the contiguous United States and the Alaska Albers Equal Area Conic projection (NAD_1983 datum) was used for Alaska.

\section{| Diversity-Productivity Relationship;}

For each of the 15 forest types across the contiguous United States and Alaska, a multiple regression analysis was conducted to test the general effect of tree species richness $(N)$ on site productivity, with forest stocking $(B)$ being accounted for:

$$
C_{i j}=\beta_{0, i}+\beta_{1, i} \cdot N_{i j}+\beta_{2, i} \cdot B_{i j} \text {, }
$$

where $C$ represents site productivity $\left(\mathrm{m}^{3} \mathrm{ha}^{-1} \mathrm{yr}^{-1}\right), i$ forest type $(i=1,2,3, \ldots, 15)$, and $j$ permanent sample plot number within the $i$ th forest type.

Coefficients $(\beta$ 's) were estimated with ordinary least squares, based on three assumptions: 1) Eq. 3 is linear in parameters; 2) the sample are random; and 3) the error term is of zero conditional mean and homoskedasticity. Although the first assumption was inconsistent with a nonlinear and asymptotic BEFR found in some early studies (e.g. Loreau et al. 2001; 
Tilman et al. 1997), in this exploratory study, I developed a linear model (Eq. 3) to test our hypothesis that species diversity was positively associated with productivity. As finding the exact BEFR functions was not an objective of this study, testing different nonlinear model forms for each of the 15 forest types across our vast study region would not be necessary. The second assumption was met through the FIA Phase 2 sample plot design (see Supplemental Material 1). Potential spatial autocorrelation within the FIA data may violate the third assumption, but current computational capacity makes it difficult to directly account for the spatial autocorrelation of a great number of observations across our study region. For simplicity, I assumed that the residuals from Eq. 3 were spatially independent.

I used the first order of $N$ in Eq. 3 without quadratic or cubic terms because our goal was to simply test if $N$ increases $C$ or not. After the model was calibrated for all the forest types, I illustrated how site productivity $(C)$ changes in response to changes in species richness $(N)$ while keeping basal area $(B)$ constant at its sample mean for that forest type. Confidence intervals (95\%) of the predicted responses of $C$ to the increase of $N$ were also estimated for all 15 forest types.

\section{Results Geographic Distribution of Tree Species Richness, Forest Productivity and Stocking}

The southeastern region, excluding the Gulf and Atlantic Coastal plains, and the Appalachian Mountains showed the highest tree species richness, whereas the majority of the mountainous regions of the western United States, the black hills region of South Dakota, western Texas, northwestern Minnesota, and the state of Florida had the lowest tree species 
richness (Fig.1). In general, forests in the eastern United States consisted of more tree species than those in the central and western parts of the country including the State of Alaska.

Forests with high site productivity were generally distributed in the western slopes of the mountain ranges in northern and central California, western Oregon and Washington, northern Idaho, the southeastern United States (except for Florida), southern Michigan, and the states of Illinois and Indiana. The areas with the most notable overall low vales of site productivity were the southern Rocky Mountains and western Texas (Fig.5).

The years in which FIA sample plots were inventoried vary from before the 1970s to after 2009, but the number of plots measured after 1990 far exceeds those that were measured prior to 1990 (Fig. 6). Of the 15 forest types, the most common ones were the oak/hickory, southern pine, maple/beech/birch, and aspen/birch. The least common were the tropical and exotic hardwoods, western hardwoods, and western oak (Table 2). Geographically, the most widely distributed forest types were the western conifer and oak/hickory (Fig. 3). It is further noteworthy that within a forest type, areas of higher species richness largely corresponded to those of higher basal area and productivity (Figs. 1- 3).

The oak/hickory and oak/pine had the overall highest levels of species richness, and the western hardwoods and pinyon/juniper had the lowest (Table 2). The mean productivity over all of the forest types studied here was $4.87 \mathrm{~m}^{3} \mathrm{ha}^{-1} \mathrm{yr}^{-1}$. The most productive forest type was the Douglas-fir type whereas the least productive the pinyon/juniper. Average species richness for all forest types combined is 6.02 (Table 2).

\section{| Diversity-Productivity Relationship}


Throughout all the 15 forest types, 13 show a positive relationship between species richness and site productivity, and only the Douglas-fir and northern pines show a negative or insignificant relationship (Table 4, Fig. 7). Of the two independent variables, basal area was the least significant predictor of site productivity, while species richness was the most significant. Both independent variables together accounted for $8.30 \%$ of variance in site productivity over the entire country. For individual forest types, the western hardwoods (47.3\%) and pinyon/juniper $(24.9 \%)$ had the best goodness-of-fit, whereas the maple/beech/birch $(0.5 \%)$ aspen/birch $(2.3 \%)$ had the least. It should be noted, however, that the goodness-of-fit does not affect the test of the species diversity-site productivity relationship.

Based on the estimated coefficients of Eq. 3 (Table 4), when $B$ was kept constant at its sample mean, site productivity was expected to increase from 0 to $7.73 \mathrm{~m}^{3} \mathrm{ha}^{-1} \mathrm{yr}^{-1}$ in the pinyon/juniper forest type as species richness increased from 1 to 19 . The oak/gum/cypress had an increase in site productivity from 4.70 to $9.80 \mathrm{~m}^{3} \mathrm{ha}^{-1} \mathrm{yr}^{-1}$ as species richness increased from 1 to 22 . The western oak saw a noticeable change in site productivity from 0.73 to $6.59 \mathrm{~m}^{3} \mathrm{ha}^{-1} \mathrm{yr}^{-1}$ in response to a change in species richness from 1 to 10 . As species richness increased from 1 to 13 , site productivity increased from 3.00 to $8.50 \mathrm{~m}^{3} \mathrm{ha}^{-1} \mathrm{yr}^{-1}$ in the tropical and exotic hardwoods (Fig. 7).

\section{Discussion}

The findings largely support, from the perspectives of forested ecosystems over a large geographic scale, a positive biodiversity-ecosystem functioning relationship (BEFR). This is consistent with other experiments based generally on controlled field experiments with herbaceous species (see Cardinale et al. 2012 and references therein). Evidence from this study in support of the positive BEFR is quite unique from previous studies because it was based upon 
436,177 ground-measured FIA plots from a large geographic scale (over 9 million $\mathrm{km}^{2}$ across the United States). Recognizing that different forest types vary in regards to how species diversity affects productivity, I categorized all the ground-measured plots into 15 forest types, and analyzed the diversity-productivity relationship specific to each forest type. The number of ground-measured plots, as well as the magnitude of geographic scale, rendered overwhelming evidence in support of a positive tree species diversity-timber productivity relationship.

The negative diversity-productivity relationship for the Douglas-fir forest type that I found (Fig. 7B) contradicts with the positive net basal area change in association with tree species diversity reported by Liang et at. (2007) for the same forest type. The main reason for this discrepancy may be in the measure of site productivity. While Liang et at. (2007) measured site productivity by net annual basal area change, which represents actual forest growth, this study quantified site productivity with MAI, which represents potential timber growth that a site could sustain. Results from these two studies indicate that although species diversity is associated with higher actual forest growth for the Douglas-fir forests in the Pacific Northwest, intensively managed commercial forests that feature low species diversity may have higher potential for timber growth. It should be noted, however, that this implication was only applicable to Douglas-fir forests, which are in general low in tree species diversity. Southern pine forests, in spite of high management intensity, still show a positive tree species diversity-timber productivity relationship (Fig. 7J). A possible explanation is that southern pine forests by nature consist of more tree species than Douglas-fir forests. Also, the niche complementarity effect (see Loreau and Hector 2001 and references therein) that contributes to the positive BEFR could therefore be more prominent in the southern pine forests. 
None of these explanations for the negative diversity-productivity relationship found in the Douglas-fir forest type are really satisfactory however. Using the fact that the previous study by Liang et at. (2007) utilizes actual basal area growth while this study utilizes potential volume growth to explain the negative diversity-productivity relationship found in the Douglas-fir forest type is in conflict with the results of the other forest types for which utilizing potential volume growth yielded a positive diversity-productivity relationship. In addition, other forest types having a low tree species diversity such as the western oak and western hardwoods showed a strong positive diversity-productivity relationship.

After analyzing the sensitivity of productivity to changes in tree species diversity within the 15 forest types in this study, a question arises. The question that arises is why does the sensitivity of productivity to changes in tree species diversity vary among these 15 forest types? Two forest types show a negative relationship between tree species diversity and productivity (Fig. 7) while others show a steep positive relationship between tree species diversity and productivity (Fig. 7). Further study is needed to analyze variables such as climatic conditions, soil conditions, and other factors which may cause the relationship to vary between different forest types. Understanding the processes which drive the relationship at the individual forest type would assist land managers in the ability to increase the productivity of desired services from specific forest types.

Due to the use of observational data, the observed trends are subject to the usual caveats of multicollinearity. However, multicollinearity does not lead to a biased diversity-productivity relationship (Dixon 2002), even though it may lead to difficulties in quantifying the variance of predicted means. The partial effects of diversity (Fig. 7) may be more uncertain due to multicollinearity. Nevertheless, multicollinearity was not excessive in the present case as the 
Variance Inflation Factor was estimated to be 1.08 using the "car" package of R (Fox and Weisberg 2011), and all the forest types show very low standard errors in predicted site productivity (Fig. 7). Another statistical caveat of this study, due to the use of observational data, is in the causal relationship between diversity and productivity. Without a controlled experiment, it is difficult to determine the cause and effect in the diversity-productivity relationship. On the other hand, this empirical evidence provides insights to forest management and biological conservation that are of a much broader applicability, both in terms of forest type and geographic scale, than what could be provided for spatially limited controlled experiments.

The fuzzed FIA plot coordinates could affect the accuracy of the estimated site productivity $(C)$, as $70 \%$ of plot elevation records and $6 \%$ of plot slope records were obtained from a DEM using the fuzzed coordinates. Nevertheless, the impact should be small, as the differences between fuzzed coordinates and true locations of FIA plots can be treated as a normally distributed random process. Furthermore, as most forests across the United States are distributed on relatively flat surfaces, bias in elevation that is caused by fuzzed coordinates was limited. For the slope data that is the most sensitive to plot locations, the accuracy of the site productivity model was maintained as $94 \%$ of the data were measured in the field and only $6 \%$ were estimated using the fuzzed coordinates.

The results of this study suggest that maintaining species diversity is an important means to maintain forest productivity, which is supported by an array of forestry studies (Caspersen and Pacala 2001; Gamfeldt et al. 2013; Kelty 1989; Lei et al. 2009; Liang et al. 2005; Liang et al. 2007; Young et al. 2011; Zhang et al. 2012). Since I analyzed the BEFR at specific forest types across the United States, I provide results relevant to the 15 primary forest types in the U.S. . These results should assist landowners in making management decisions that are relevant to the 
specific forest types that they respectively manage. These findings also imply that productivity of forests across the United States may be impaired by the loss of both woody and nonwoody plant species in forested ecosystems (Fleming et al. 2011), and that biological conservation, due to its potential benefits in maintaining forest productivity, can have profound impacts on the productivity of selected services that can be obtained from forests across the United States

\section{Acknowledgements}

I am obligated to Karren Waddell and Charles J. Barnett for assistance with FIA data. I want to thank Mo Zhou, Jacquelyn Strager, George Merovich, Catherine Artis, and Eric King for statistical and mapping assistance. This research is supported in parts by the United States Department of Agriculture McIntire-Stennis Act Fund WVA00104, and by the Division of Forestry and Natural Resources, West Virginia University. 


\section{References}

Assmann, E. 1970. The Principles of Forest Yield Study. Pergamon Press, Oxford, UK.

Bechtold, W.A., and Scott, C.T. 2005. The forest inventory and analysis plot design. USDA Forest Service. Buongiorno, J., Peyron, J.L., Houllier, F., and Bruciamacchie, M. 1995. Growth and management of mixed-species, uneven-aged forests in the French Jura: implications for economic returns and tree diversity. For. Sci. 41(3): 397-429.

Cardinale, B.J., Duffy, J.E., Gonzalez, A., Hooper, D.U., Perrings, C., Venail, P., Narwani, A., Mace, G.M., Tilman, D., Wardle, D.A., Kinzig, A.P., Daily, G.C., Loreau, M., Grace, J.B., Larigauderie, A., Srivastava, D.S., and Naeem, S. 2012. Biodiversity loss and its impact on humanity. Nature 486(7401): 59-67.

Caspersen, J.P., and Pacala, S.W. 2001. Successional diversity and forest ecosystem function. Ecol. Res. 16(5): 895-903.

Chen, H.Y.H., Klinka, K., Mathey, A.H., Wang, X., Varga, P., and Chourmouzis, C. 2003. Are mixed-species stands more productive than single-species stands: an empirical test of three forest types in British Columbia and Alberta. Can. J. For. Res. 33(7): 1227-1237.

Dixon, G.E. 2002. Essential FVS: A user's guide to the Forest Vegetation Simulator. USDA-Forest Service, Forest Management Service Center.

FAO. 2012. State of the World's Forests 2012. Food and Agriculture Organization of the United Nations. Fleming, R., Brown, N., Jenik, J., Kahumbu, P., and Plesnik, J. 2011. Emerging Perspectives on Forest Biodiversity. In UNEP Year Book 2011. Edited by United Nations Environment Program. UNEP, Nairobi, Kenya. pp. 46-59.

Fox, J., and Weisberg, S. 2011. An R companion to applied regression. Sage, Thousand Oaks, CA. Gamfeldt, L., Snall, T., Bagchi, R., Jonsson, M., Gustafsson, L., Kjellander, P., Ruiz-Jaen, M.C., Froberg, M., Stendahl, J., Philipson, C.D., Mikusinski, G., Andersson, E., Westerlund, B., Andren, H., Moberg, F., Moen, J., and Bengtsson, J. 2013. Higher levels of multiple ecosystem services are found in forests with more tree species. Nat Commun 4: 1340.

Gesch, D., Oimoen, M., Greenlee, S., Nelson, C., Steuck, M., and Tyler, D. 2002. The national elevation dataset. Photogramm. Eng. Remote Sensing 68(1): 5-32.

Gillespie, A.J. 1999. Rationale for a national annual forest inventory program. Journal of Forestry $\mathbf{9 7 ( 1 2 ) : ~}$ 16-20.

Haight, R.G., and Monserud, R.A. 1990. Optimizing Any-Aged Management of Mixed-Species Stands: II. Effects of Decision Criteria. For. Sci. 36(1): 125-144.

Hanson, E.J., Azuma, D.L., and Hiserote, B.A. 2003. Site index equations and mean annual increment equations for Pacific Northwest Research Station forest inventory and analysis inventories, 1985-2001.

Hasse, W.D., and Ek, A.R. 1981. A simulated comparison of yields for even-versus uneven-aged management of northern hardwood stands. J. Environ. Manage. 12: 235-246.

Hernández-Stefanoni, J.L., and Dupuy, J.M. 2007. Mapping species density of trees, shrubs and vines in a tropical forest, using field measurements, satellite multiespectral imagery and spatial interpolation. Biodiversity and conservation 16(13): 3817-3833.

Hernandez-Stefanoni, J.L., and Ponce-Hernandez, R. 2006. Mapping the spatial variability of plant diversity in a tropical forest: comparison of spatial interpolation methods. Environ. Monit. Assess. 117(13): 307-334.

Hooper, D.U., Chapin, F.S., Ewel, J.J., Hector, A., Inchausti, P., Lavorel, S., Lawton, J.H., Lodge, D.M., Loreau, M., Naeem, S., Schmid, B., Setala, H., Symstad, A.J., Vandermeer, J., and Wardle, D.A. 2005. Effects of biodiversity on ecosystem functioning: A consensus of current knowledge. Ecol. Monogr. 75(1): 3-35.

Kelty, M.J. 1989. Productivity of New England hemlock/hardwood stands as affected by species composition and canopy structure. For. Ecol. Manage. 28(3-4): 237-257. doi: 10.1016/0378-

1127(89)90006-6. 
Köble, R., and Seufert, G. 2001. Novel maps for forest tree species in Europe. In Proceedings of the 8th European symposium on the physico-chemical behaviour of air pollutants: a changing atmosphere.

Edited by J. Hjorth and F. Raes and G. Angeletti, Torino, Italy. pp. 17-20.

Kreft, H., and Jetz, W. 2007. Global patterns and determinants of vascular plant diversity. PNAS 104(14): 5925-5930.

Lei, X., Wang, W., and Peng, C. 2009. Relationships between stand growth and structural diversity in spruce-dominated forests in New Brunswick, Canada. Can. J. For. Res. 39: 1835-1847.

Leuschner, C., Jungkunst, H.F., and Fleck, S. 2009. Functional role of forest diversity: pros and cons of synthetic stands and across-site comparisons in established forests. Basic and Applied Ecology 10(1): 1-9. Liang, J. 2012. Mapping large-scale forest dynamics: a geospatial approach. Landscape ecology 27(8): 1091-1108.

Liang, J., Buongiorno, J., and Monserud, R.A. 2005. Growth and yield of all-aged Douglas-fir/western hemlock stands: a Matrix model with stand diversity effects. Can. J. For. Res. 35(10): 2369-2382.

Liang, J., Buongiorno, J., and Monserud, R.A. 2006. Bootstrap simulation and response surface optimization of management regimes for Douglas-fir/western hemlock stands. For. Sci. 52(5): 579-594.

Liang, J., Buongiorno, J., Monserud, R.A., Kruger, E.L., and Zhou, M. 2007. Effects of diversity of tree species and size on forest basal area growth, recruitment, and mortality. For. Ecol. Manage. 243: 116127.

Lister, A., Scott, C., King, S., Hoppus, M., Butler, B., and Griffith, D. 2002. Strategies for preserving owner privacy in the national information management system of the USDA Forest Service's forest inventory and analysis unit. In The Fourth Annual Forest Inventory and Analysis Symposium. Edited by R.E.

McRoberts. USDA Forest Service, New Orleans, LA. pp. 163-166.

Loreau, M., and Hector, A. 2001. Partitioning selection and complementarity in biodiversity experiments. Nature 412(6842): 72-76.

Loreau, M., Naeem, S., Inchausti, P., Bengtsson, J., Grime, J.P., Hector, A., Hooper, D.U., Huston, M.A., Raffaelli, D., Schmid, B., Tilman, D., and Wardle, D.A. 2001. Biodiversity and ecosystem functioning: current knowledge and future challenges. Science 294(804): 804-808.

Naeem, S., Duffy, J.E., and Zavaleta, E. 2012. The Functions of Biological Diversity in an Age of Extinction. Science 336(6087): 1401-1406. doi: 10.1126/science.1215855.

Paquette, A., and Messier, C. 2011. The effect of biodiversity on tree productivity: from temperate to boreal forests. Global Ecol. Biogeogr. 20(1): 170-180. doi: 10.1111/j.1466-8238.2010.00592.x.

Ricketts, T.H. 1999. Terrestrial ecoregions of North America: a conservation assessment. Island Press, Washington, DC.

Ruefenacht, B., Finco, M.V., Nelson, M.D., Czaplewski, R., Helmer, E.H., Blackard, J.A., Holden, G.R., Lister, A.J., Salajanu, D., Weyermann, D., and Winterberger, K. 2008. Conterminous US and Alaska forest type mapping using forest inventory and analysis data. Photogramm. Eng. Remote Sensing 74(11): 13791388.

Stage, A.R., and Salas, C. 2007. Interaction of elevation, aspect, and slope in models of forest species composition and productivity. For. Sci. 53(4): 486-492.

Symstad, A.J., Chapin, F.S., Wall, D.H., Gross, K.L., Huenneke, L.F., Mittelbach, G.G., Peters, D.P., and Tilman, D. 2003. Long-term and large-scale perspectives on the relationship between biodiversity and ecosystem functioning. Bioscience 53(1): 89-98.

Tilman, D., Lehman, C.L., and Thomson, K.T. 1997. Plant diversity and ecosystem productivity: Theoretical considerations. PNAS 94(5): 1857-1861.

Vilà, M., Vayreda, J., Gracia, C., and Ibáñez, J.J. 2003. Does tree diversity increase wood production in pine forests? Oecologia 135: 299-303. 
Woodall, C.W., Amacher, M.C., Bechtold, W.A., Coulston, J.W., Jovan, S., Perry, C.H., Randolph, K.C., Schulz, B.K., Smith, G.C., and Tkacz, B. 2011. Status and future of the forest health indicators program of the USA. Environmental monitoring and assessment 177(1-4): 419-436.

Woudenberg, S., Conkling, B., O'Connell, B., LaPoint, E., Turner, J., Waddell, K., Boyer, D., Christensen, G., and Ridley, T. 2011. The Forest Inventory and Analysis Database: description and users manual version 5.1 for Phase 2. US Department of Ahgriculture, Forest Service.

Young, B., Liang, J., and Stuart Chapin III, F. 2011. Effects of species and tree size diversity on recruitment in the Alaskan boreal forest: A geospatial approach. For. Ecol. Manage. 262(8): 1608-1617. doi: 10.1016/j.foreco.2011.07.011.

Zhang, Y., Chen, H.Y.H., and Reich, P.B. 2012. Forest productivity increases with evenness, species richness and trait variation: a global meta-analysis. J. Ecol. 100(3): 742-749. doi: 10.1111/j.1365-

2745.2011.01944.x. 


\section{Tables}

\section{Table 1. Definition and units for variables used in this study.}

\begin{tabular}{|c|c|c|c|}
\hline Variable & Units & Short Definition & Long Definition \\
\hline$C$ & $\mathrm{~m}^{3} \mathrm{ha}^{-1} \mathrm{yr}^{-1}$ & Site productivity & $\begin{array}{l}\text { A measure of the potential timber growth } \\
\text { that the site is capable of producing. It is } \\
\text { based on the average annual increment of } \\
\text { naturally occurring, fully stocked stands }\end{array}$ \\
\hline$B$ & $\mathrm{~m}^{2} \mathrm{ha}^{-1}$ & Stand basal area & $\begin{array}{l}\text { Total stand basal area of all the living trees } \\
\text { from the most current measurement in FIA } \\
\text { data }\end{array}$ \\
\hline E & $\mathrm{m}$ & Plot elevation & $\begin{array}{l}\text { The vertical distance that a plot is located } \\
\text { from sea level. Positive values indicate that } \\
\text { the plot is located above sea level while } \\
\text { negative values indicate that the plot was } \\
\text { located below sea level. } 70 \% \text { of the values } \\
\text { were obtained from the DEM of the United } \\
\text { States and 30\% from ground measurement }\end{array}$ \\
\hline$S$ & degrees & Slope & $\begin{array}{l}\text { The angle of slope in degrees } 5.6 \% \text { of the } \\
\text { values were obtained from the DEM of the } \\
\text { United States and } 94.4 \% \text { from ground } \\
\text { measurement }\end{array}$ \\
\hline$N$ & & Species richness & $\begin{array}{l}\text { The total number of different species of } \\
\text { woody trees present on the plot }\end{array}$ \\
\hline$\Phi$ & degrees & Latitude & Latitude of the plot in NAD 83 \\
\hline$\Lambda$ & degrees & Longitude & Longitude of the plot in NAD 83 \\
\hline
\end{tabular}


Table 2. Summary statistics by forest type.

\begin{tabular}{|c|c|c|c|c|c|c|c|}
\hline & $\begin{array}{l}\text { Productivity } \\
\left(\mathrm{m}^{3} \mathrm{ha}^{-1} \mathrm{year}^{-1}\right)\end{array}$ & $\begin{array}{l}\text { Number of } \\
\text { Species }\end{array}$ & $\begin{array}{c}\text { Basal area } \\
\left(\mathrm{m}^{2} \mathrm{ha}^{-1}\right)\end{array}$ & $\begin{array}{c}\text { Elevation } \\
(\mathrm{km})\end{array}$ & $\begin{array}{c}\text { Slope } \\
\text { (degrees) }\end{array}$ & $\begin{array}{l}\text { Latitude } \\
\text { (degrees) }\end{array}$ & $\begin{array}{l}\begin{array}{c}\text { Longitude } \\
\text { (degrees) }\end{array}\end{array}$ \\
\hline \multicolumn{8}{|c|}{ National (all forest types combined) } \\
\hline Mean & 4.87 & 6.02 & 19.27 & 0.62 & 6.54 & 38.67 & -89.05 \\
\hline Std. & 2.65 & 3.43 & 11.98 & 0.75 & 8.21 & 5.68 & 11.26 \\
\hline Max. & 14.89 & 24.00 & 188.99 & 3.92 & 60.23 & 61.45 & -66.99 \\
\hline Min. & 0.00 & 1.00 & 0.00 & -0.08 & 0.00 & 24.63 & -153.85 \\
\hline $\mathrm{n}$ & 436,177 & 436,177 & 436,177 & 436,177 & 436,177 & 436,177 & 436,177 \\
\hline \multicolumn{8}{|c|}{ Pinyon/juniper } \\
\hline Mean & 0.45 & 2.21 & 17.67 & 1.84 & 11.32 & 37.06 & -109.99 \\
\hline Std. & 1.20 & 1.41 & 13.27 & 0.51 & 9.72 & 2.84 & 5.56 \\
\hline Max. & 12.30 & 19.00 & 130.34 & 3.35 & 57.17 & 48.14 & -71.90 \\
\hline Min. & 0.00 & 1.00 & 0.00 & -0.07 & 0.00 & 29.26 & -122.77 \\
\hline $\mathrm{n}$ & 16,709 & 16,709 & 16,709 & 16,709 & 16,709 & 16,709 & 16,709 \\
\hline \multicolumn{8}{|c|}{ Douglas-fir } \\
\hline Mean & 7.20 & 4.40 & 23.95 & 0.15 & 3.69 & 45.36 & -121.62 \\
\hline Std. & 3.40 & 2.10 & 26.70 & 0.20 & 8.59 & 2.07 & 1.99 \\
\hline Max. & 14.67 & 13.00 & 188.99 & 1.77 & 44.71 & 48.99 & -116.56 \\
\hline Min. & 0.00 & 1.00 & 0.00 & 0.00 & 0.00 & 42.00 & -124.46 \\
\hline $\mathrm{n}$ & 5,924 & 5,924 & 5,924 & 5,924 & 5,924 & 5,924 & 5,924 \\
\hline \multicolumn{8}{|c|}{ Oak/pine } \\
\hline Mean & 5.62 & 6.85 & 17.71 & 0.55 & 4.91 & 33.79 & -86.46 \\
\hline Std. & 2.59 & 3.59 & 10.71 & 0.70 & 6.52 & 3.04 & 6.68 \\
\hline Max. & 14.77 & 22.00 & 80.45 & 3.64 & 60.23 & 47.97 & -68.82 \\
\hline Min. & 0.00 & 1.00 & 0.00 & -0.03 & 0.00 & 26.25 & -103.00 \\
\hline $\mathrm{n}$ & 14,886 & 14,886 & 14,886 & 14,886 & 14,886 & 14,886 & 14,886 \\
\hline \multicolumn{8}{|c|}{ Oak/gum/cypress } \\
\hline Mean & 6.00 & 6.38 & 20.99 & 0.56 & 1.60 & 32.39 & -85.39 \\
\hline Std. & 2.55 & 3.43 & 13.69 & 0.73 & 3.49 & 2.42 & 5.93 \\
\hline Max. & 14.83 & 22.00 & 136.45 & 3.80 & 57.17 & 42.60 & -71.39 \\
\hline Min. & 0.00 & 1.00 & 0.00 & 0.00 & 0.00 & 24.63 & -101.36 \\
\hline $\mathrm{n}$ & 23,350 & 23,350 & 23,350 & 23,350 & 23,350 & 23,350 & 23,350 \\
\hline \multicolumn{8}{|c|}{ Elm/ash/cottonwood } \\
\hline Mean & 4.84 & 5.48 & 16.78 & 0.44 & 3.62 & 38.40 & -91.46 \\
\hline Std. & 3.01 & 3.25 & 10.98 & 0.57 & 6.20 & 5.37 & 6.51 \\
\hline Max. & 14.83 & 22.00 & 130.61 & 3.60 & 43.53 & 61.43 & -67.16 \\
\hline Min. & 0.00 & 1.00 & 0.00 & 0.00 & 0.00 & 26.12 & -153.45 \\
\hline $\mathrm{n}$ & 11,509 & 11,509 & 11,509 & 11,509 & 11,509 & 11,509 & 11,509 \\
\hline
\end{tabular}


Table 2 continued

\begin{tabular}{|c|c|c|c|c|c|c|c|}
\hline & $\begin{array}{l}\text { Productivity } \\
\left(\mathrm{m}^{3} \mathrm{ha}^{-1} \mathrm{year}^{-1}\right)\end{array}$ & $\begin{array}{l}\text { Number of } \\
\text { Species }\end{array}$ & $\begin{array}{c}\text { Basal area } \\
\left(\mathrm{m}^{2} \mathrm{ha}^{-1}\right)\end{array}$ & $\begin{array}{l}\begin{array}{c}\text { Elevation } \\
(\mathrm{km})\end{array}\end{array}$ & $\begin{array}{c}\text { Slope } \\
\text { (degrees) }\end{array}$ & $\begin{array}{l}\text { Latitude } \\
\text { (degrees) }\end{array}$ & $\begin{array}{l}\begin{array}{l}\text { Longitude } \\
\text { (degrees) }\end{array}\end{array}$ \\
\hline \multicolumn{8}{|c|}{ Aspen/birch } \\
\hline Mean & 4.64 & 4.77 & 18.42 & 0.60 & 4.19 & 45.76 & -90.76 \\
\hline Std. & 2.10 & 2.32 & 10.53 & 0.72 & 5.33 & 2.30 & 6.43 \\
\hline Max. & 14.61 & 16.00 & 95.88 & 3.68 & 56.48 & 61.41 & -67.22 \\
\hline Min. & 0.00 & 1.00 & 0.00 & 0.00 & 0.00 & 33.61 & -151.73 \\
\hline $\mathrm{n}$ & 46,411 & 46,411 & 46,411 & 46,411 & 46,411 & 46,411 & 46,411 \\
\hline \multicolumn{8}{|c|}{ Southern pine } \\
\hline Mean & 6.07 & 6.02 & 17.73 & 0.55 & 3.03 & 32.74 & -85.54 \\
\hline Std. & 2.44 & 3.51 & 11.46 & 0.71 & 4.59 & 2.25 & 5.97 \\
\hline Max. & 14.81 & 23.00 & 140.89 & 3.86 & 57.17 & 44.00 & -69.99 \\
\hline Min. & 0.00 & 1.00 & 0.00 & -0.08 & 0.00 & 25.75 & -101.22 \\
\hline $\mathrm{n}$ & 82,573 & 82,573 & 82,573 & 82,573 & 82,573 & 82,573 & 82,573 \\
\hline \multicolumn{8}{|c|}{ Oak/hickory } \\
\hline Mean & 5.04 & 7.78 & 18.81 & 0.45 & 9.58 & 37.37 & -85.48 \\
\hline Std. & 2.37 & 3.45 & 9.80 & 0.58 & 9.12 & 3.15 & 5.97 \\
\hline Max. & 14.89 & 24.00 & 87.61 & 3.92 & 57.17 & 48.99 & -68.74 \\
\hline Min. & 0.00 & 1.00 & 0.00 & -0.02 & 0.00 & 25.61 & -104.37 \\
\hline $\mathrm{n}$ & 132,242 & 132,242 & 132,242 & 132,242 & 132,242 & 132,242 & 132,242 \\
\hline \multicolumn{8}{|c|}{ Maple/beech/birch } \\
\hline Mean & 4.19 & 6.22 & 21.84 & 0.44 & 5.88 & 44.15 & -82.11 \\
\hline Std. & 2.05 & 2.57 & 10.89 & 0.47 & 6.68 & 2.28 & 8.45 \\
\hline Max. & 14.64 & 20.00 & 80.57 & 3.71 & 57.00 & 49.00 & -67.11 \\
\hline Min. & 0.00 & 1.00 & 0.00 & 0.00 & 0.00 & 34.81 & -102.81 \\
\hline $\mathrm{n}$ & 47,350 & 47,350 & 47,350 & 47,350 & 47,350 & 47,350 & 47,350 \\
\hline \multicolumn{8}{|c|}{ Tropical and exotic hardwoods } \\
\hline Mean & 3.98 & 3.14 & 14.71 & 0.54 & 0.95 & 28.44 & -86.44 \\
\hline Std. & 2.66 & 2.52 & 13.72 & 0.64 & 3.09 & 1.74 & 7.14 \\
\hline Max. & 12.33 & 13.00 & 60.24 & 3.55 & 34.32 & 35.32 & -80.11 \\
\hline Min. & 0.00 & 1.00 & 0.00 & 0.00 & 0.00 & 25.79 & -120.48 \\
\hline $\mathrm{n}$ & 408 & 408 & 408 & 408 & 408 & 408 & 408 \\
\hline \multicolumn{8}{|c|}{ Spruce/fir and exotic softwoods } \\
\hline Mean & 3.76 & 4.79 & 20.32 & 0.47 & 2.72 & 46.54 & -85.49 \\
\hline Std. & 1.96 & 2.34 & 11.99 & 0.56 & 4.09 & 1.49 & 10.12 \\
\hline Max. & 14.57 & 15.00 & 80.86 & 3.68 & 56.48 & 61.45 & -66.99 \\
\hline Min. & 0.00 & 1.00 & 0.00 & 0.00 & 0.00 & 38.27 & -151.72 \\
\hline $\mathrm{n}$ & 18,761 & 18,761 & 18,761 & 18,761 & 18,761 & 18,761 & 18,761 \\
\hline
\end{tabular}


Table 2 continued

\begin{tabular}{|c|c|c|c|c|c|c|c|}
\hline & $\begin{array}{c}\text { Productivity } \\
\left(\mathrm{m}^{3} \mathrm{ha}^{-1} \text { year }^{-1}\right)\end{array}$ & $\begin{array}{c}\text { Number of } \\
\text { Species }\end{array}$ & $\begin{array}{c}\text { Basal area } \\
\left(\mathrm{m}^{2} \mathrm{ha}^{-1}\right)\end{array}$ & $\begin{array}{c}\text { Elevation } \\
(\mathrm{km})\end{array}$ & $\begin{array}{c}\text { Slope } \\
\text { (degrees) }\end{array}$ & $\begin{array}{r}\text { Latitude } \\
\text { (degrees) }\end{array}$ & $\begin{array}{c}\begin{array}{c}\text { Longitude } \\
\text { (degrees) }\end{array} \\
\end{array}$ \\
\hline \multicolumn{8}{|c|}{ Northern pines } \\
\hline Mean & 4.51 & 4.68 & 19.75 & 0.43 & 3.85 & 44.84 & -85.23 \\
\hline Std. & 2.19 & 2.48 & 11.46 & 0.53 & 5.33 & 2.01 & 6.76 \\
\hline Max. & 14.61 & 15.00 & 82.53 & 3.56 & 41.98 & 49.30 & -67.58 \\
\hline Min. & 0.00 & 1.00 & 0.00 & 0.00 & 0.00 & 26.32 & -96.12 \\
\hline $\mathrm{n}$ & 9,132 & 9,132 & 9,132 & 9,132 & 9,132 & 9,132 & 9,132 \\
\hline \multicolumn{8}{|c|}{ Western conifers } \\
\hline Mean & 4.08 & 2.75 & 24.53 & 1.86 & 15.53 & 43.00 & -113.92 \\
\hline Std. & 2.77 & 1.43 & 17.57 & 0.78 & 10.57 & 4.58 & 6.88 \\
\hline Max. & 14.79 & 10.00 & 165.70 & 3.70 & 57.17 & 61.11 & -95.06 \\
\hline Min. & 0.00 & 1.00 & 0.00 & 0.00 & 0.00 & 31.79 & -153.85 \\
\hline $\mathrm{n}$ & 21,791 & 21,791 & 21,791 & 21,791 & 21,791 & 21,791 & 21,791 \\
\hline \multicolumn{8}{|c|}{ Western hardwoods } \\
\hline Mean & 2.88 & 2.08 & 15.69 & 0.94 & 10.56 & 36.87 & -112.68 \\
\hline Std. & 4.43 & 1.46 & 19.66 & 0.76 & 12.25 & 5.57 & 8.39 \\
\hline Max. & 14.86 & 8.00 & 184.50 & 3.16 & 47.72 & 48.99 & -99.21 \\
\hline Min. & 0.00 & 1.00 & 0.00 & -0.02 & 0.00 & 29.04 & -124.60 \\
\hline $\mathrm{n}$ & 1,924 & 1,924 & 1,924 & 1,924 & 1,924 & 1,924 & 1,924 \\
\hline \multicolumn{8}{|c|}{ Western oak } \\
\hline Mean & 1.61 & 2.35 & 14.38 & 1.34 & 16.87 & 36.78 & -113.99 \\
\hline Std. & 2.98 & 1.37 & 13.21 & 0.80 & 11.71 & 3.29 & 7.14 \\
\hline Max. & 14.68 & 10.00 & 138.16 & 3.11 & 57.17 & 47.47 & -98.45 \\
\hline Min. & 0.00 & 1.00 & 0.00 & 0.00 & 0.00 & 29.57 & -124.20 \\
\hline $\mathrm{n}$ & 3,207 & 3,207 & 3,207 & 3,207 & 3,207 & 3,207 & 3,207 \\
\hline
\end{tabular}

Note:

Std: Standard Deviation;

n: total number of FIA plots. 
Table 3. Parameters of the site productivity model.

\begin{tabular}{lrrrr}
\hline & \multicolumn{3}{c}{ Independent Variables } & \\
\cline { 2 - 4 } & SITECLCD & $E$ & $S$ & Constant \\
\hline Coef. & -2.438 & 0.081 & 0.001 & 16.980 \\
$S E$ & 0.001 & 0.001 & 0.000 & 0.002 \\
$P$ & $<.0001$ & $<.0001$ & $<.0001$ & $<.0001$ \\
$R^{2}$ & 0.98 & & & \\
$d F$ & 436,174 & & & \\
\hline
\end{tabular}


Table 4. Parameters of site productivity models by forest type with predictor variables of species richness, basal area, elevation, and slope. Level of significance: $<0.001$ : $* * * ; 0.001$ : ${ }^{* *} ; 0.01$ : ${ }^{*} ; 0.05: \bullet$

\begin{tabular}{|c|c|c|c|c|c|c|}
\hline \multirow[b]{2}{*}{ Forest Type } & \multirow[b]{2}{*}{ Number of Plots } & \multirow[b]{2}{*}{ Adjusted $\mathrm{R}^{2}$} & \multicolumn{4}{|c|}{$\begin{array}{l}\text { Coefficients and Level of } \\
\text { Significance }\end{array}$} \\
\hline & & & $N$ & & $B$ & \\
\hline Pinyon/juniper & 16,709 & 0.249 & 0.433 & $* * *$ & -0.007 & $* * *$ \\
\hline Douglas-fir & 5,924 & 0.04 & -0.044 & $*$ & 0.026 & $* * *$ \\
\hline Oak/pine & 14,886 & 0.103 & 0.174 & $* * *$ & 0.033 & $* * *$ \\
\hline Oak/gum/cypress & 23,350 & 0.107 & 0.243 & $* * *$ & 0.0002 & \\
\hline Elm/ash/cottonwood & 11,509 & 0.137 & 0.25 & $* * *$ & 0.044 & $* * *$ \\
\hline Aspen/birch & 46,411 & 0.023 & 0.095 & $* * *$ & 0.015 & $* * *$ \\
\hline Southern pine & 82,573 & 0.087 & 0.165 & $* * *$ & 0.024 & $* * *$ \\
\hline Oak/hickory & 132,242 & 0.033 & 0.09 & $* * *$ & 0.021 & $* * *$ \\
\hline Maple/beech/birch & 47,350 & 0.005 & 0.055 & $* * *$ & 0.0001 & \\
\hline $\begin{array}{c}\text { Tropical and exotic } \\
\text { hardwoods }\end{array}$ & 408 & 0.247 & 0.459 & $* * *$ & 0.022 & $*$ \\
\hline Northern pines & 9,132 & 0.037 & 0.001 & & 0.037 & $* * *$ \\
\hline $\begin{array}{l}\text { Spruce/fir and } \\
\text { exotic softwoods }\end{array}$ & 18,761 & 0.044 & 0.171 & $* * *$ & 0.003 & • \\
\hline Western conifers & 21,791 & 0.155 & 0.384 & $* * *$ & 0.044 & $* * *$ \\
\hline Western hardwoods & 1,924 & 0.473 & 1.392 & $* * *$ & 0.066 & $* * *$ \\
\hline Western oak & 3,207 & 0.205 & 0.651 & $* * *$ & 0.051 & $* * *$ \\
\hline National & 436,177 & 0.083 & 0.202 & $* * *$ & 0.015 & $* * *$ \\
\hline
\end{tabular}




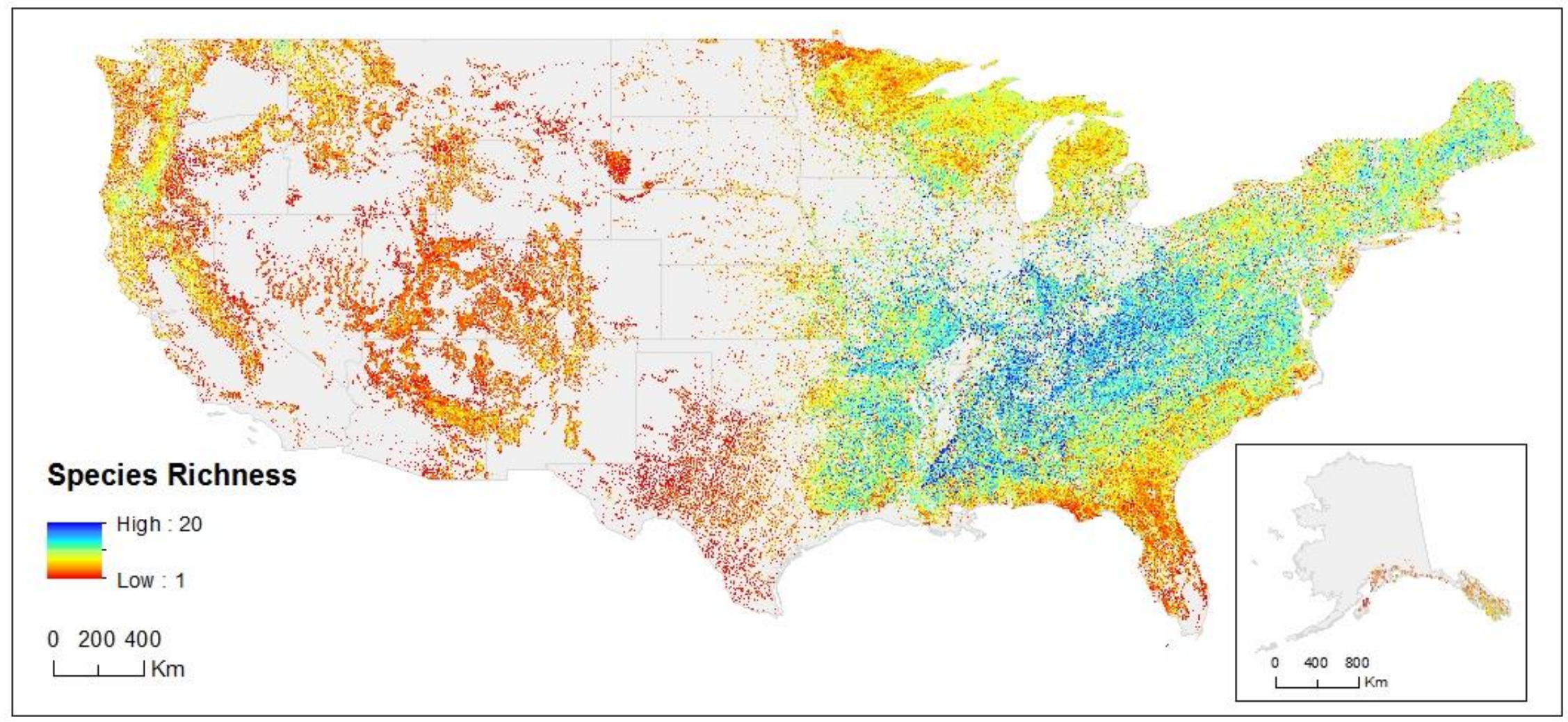

Figure 1. Richness of woody plant species across the 48 contiguous U.S. states and Alaska, derived from FIA ground measurements completed between 1968 and 2011. GCS_WGS_1984 projection for the main map and Alaska Albers Equal Area Conic projection for the inset. 


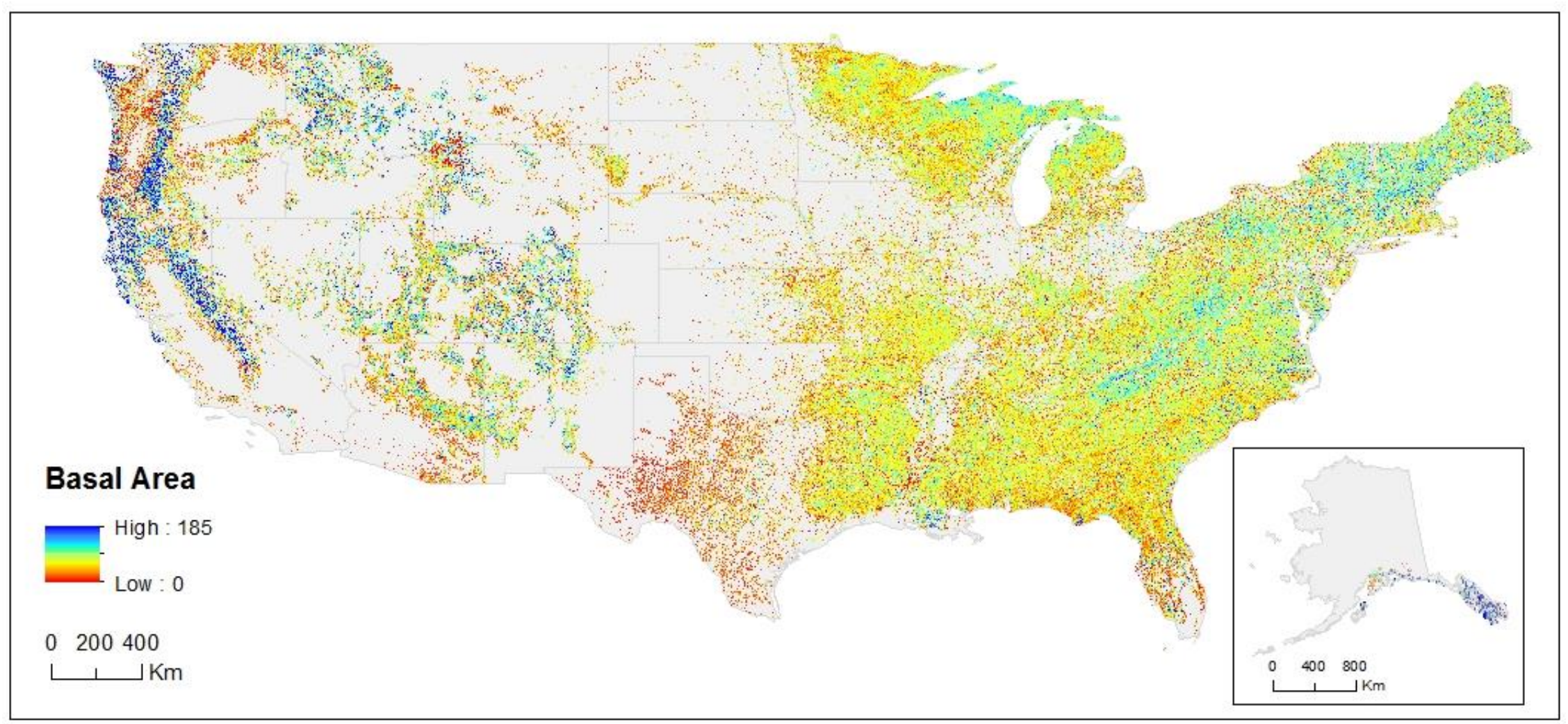

Figure 2. Total forest stand basal area $\left(\mathrm{m}^{2} \mathrm{ha}^{-1}\right)$ across the 48 contiguous U.S. states and Alaska, derived from FIA ground measurements completed between 1968 and 2011. GCS_WGS_1984 projection for the main map and Alaska Albers Equal Area Conic projection for the inset. 


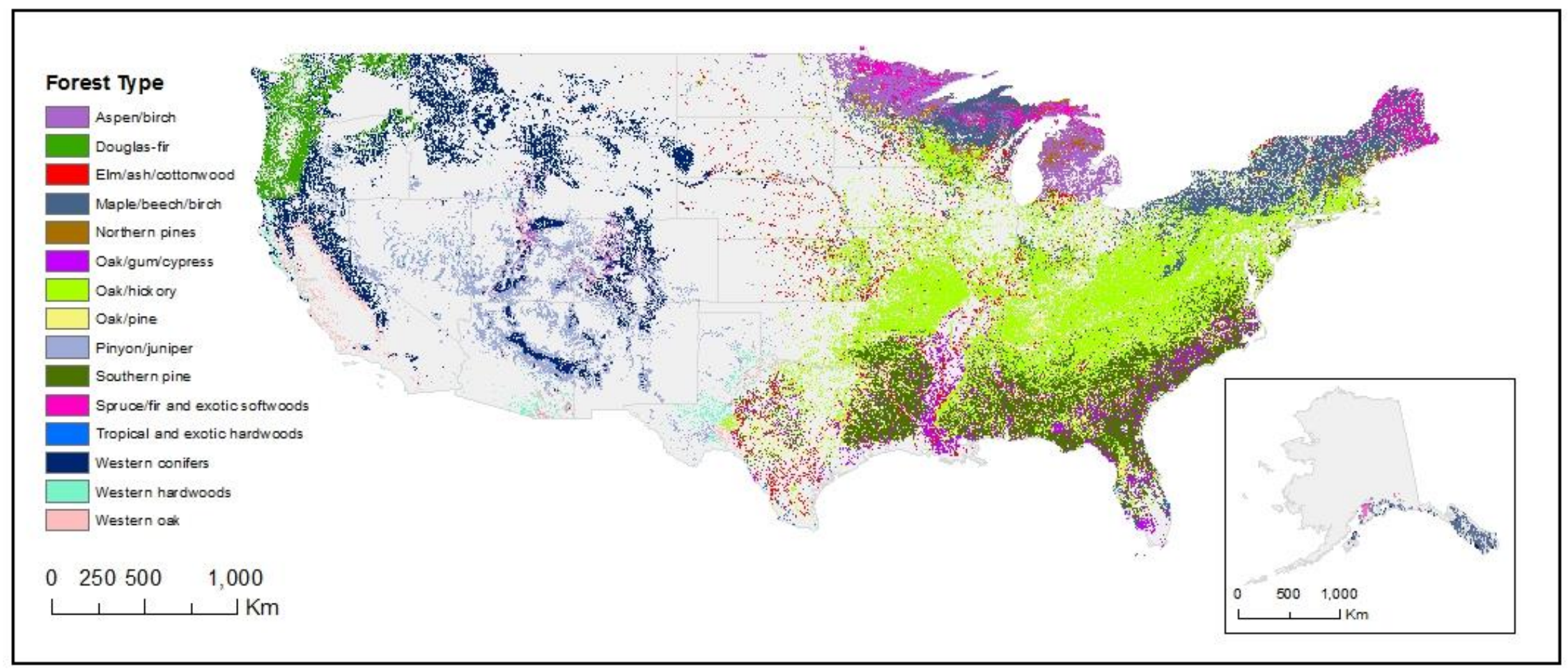

Figure 3. Forest types across the 48 contiguous U.S. states and Alaska, derived from both a forest type group map of the contiguous United States and a forest type group map of Alaska. Both of these maps were remakes from Ruefenacht et al. (2008) using FIA point data. GCS_WGS_1984 projection for the main map and Alaska Albers Equal Area Conic projection for the inset. 


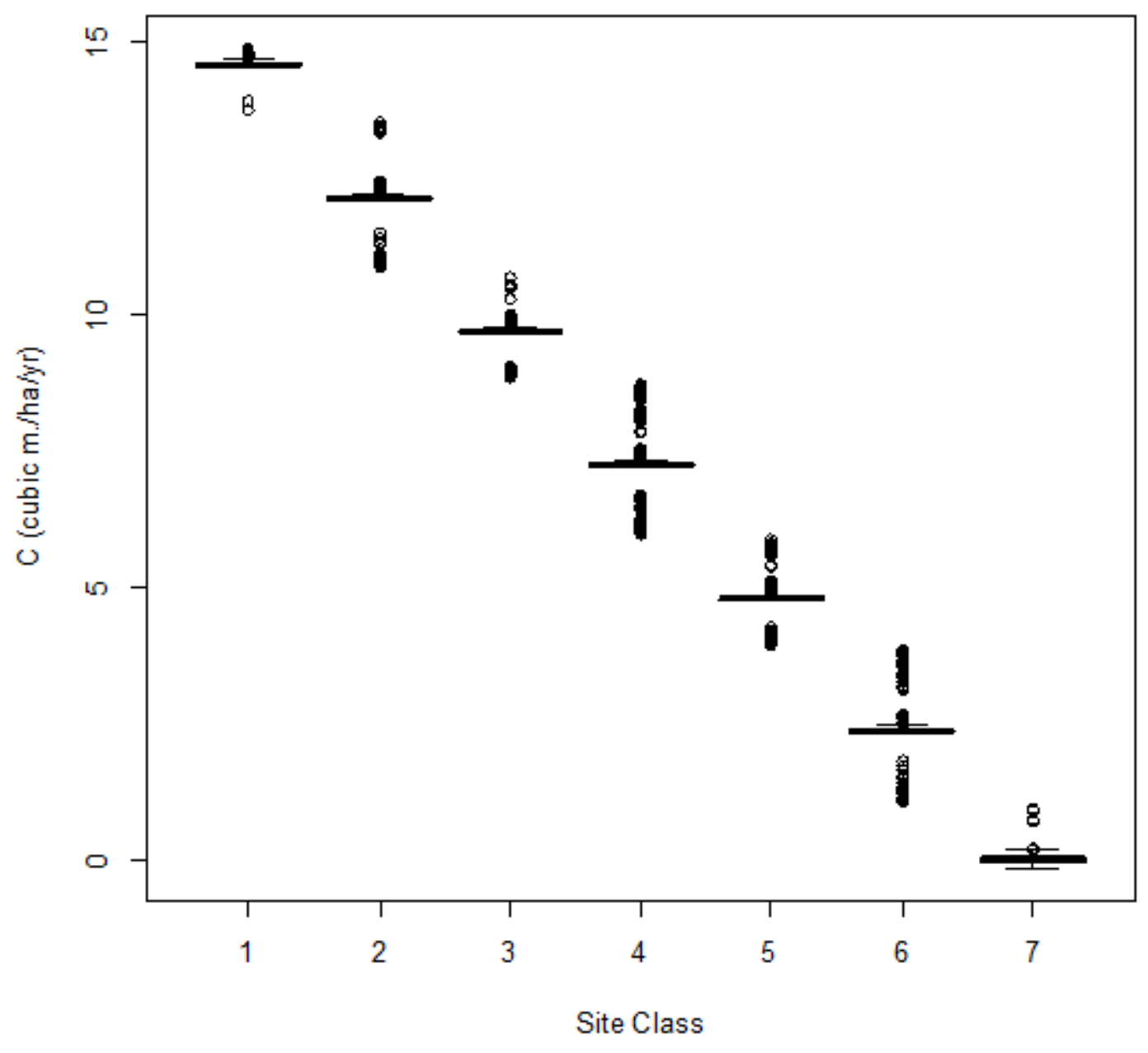

Figure 4. Site productivity class codes ( 1 through 7$)$ and continuous values of site productivity estimated by the site productivity model (Eq. 2). 


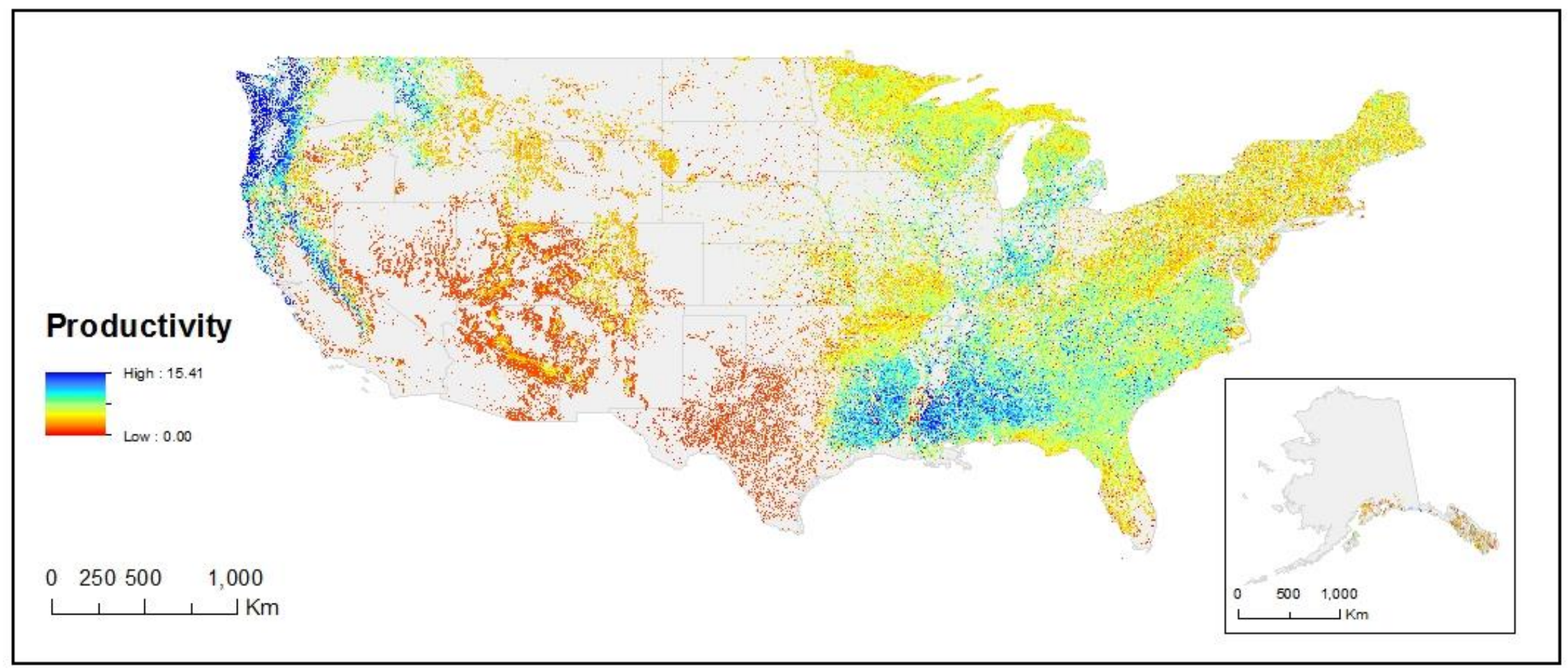

Figure 5. Forest productivity $\left(\mathrm{m}^{3} \mathrm{ha}^{-1} \mathrm{yr}^{-1}\right)$ across the 48 contiguous U.S. states and Alaska, derived from FIA ground measurements completed between 1968 and 2011. GCS_WGS_1984 projection for the main map and Alaska Albers Equal Area Conic projection for the inset. 


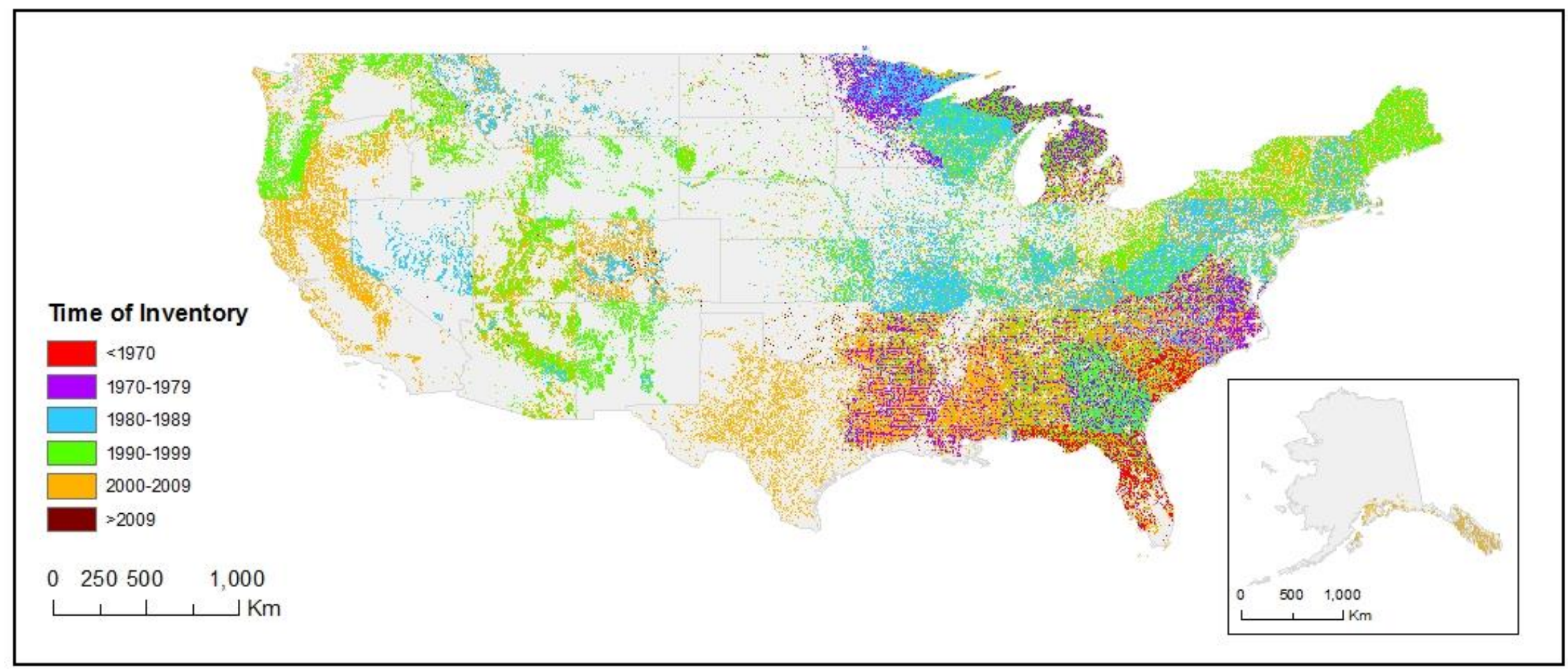

Figure 6. Time of inventory for all the FIA plots across the 48 contiguous U.S. states and Alaska. GCS_WGS_1984 projection for the main map and Alaska Albers Equal Area Conic projection for the inset. 


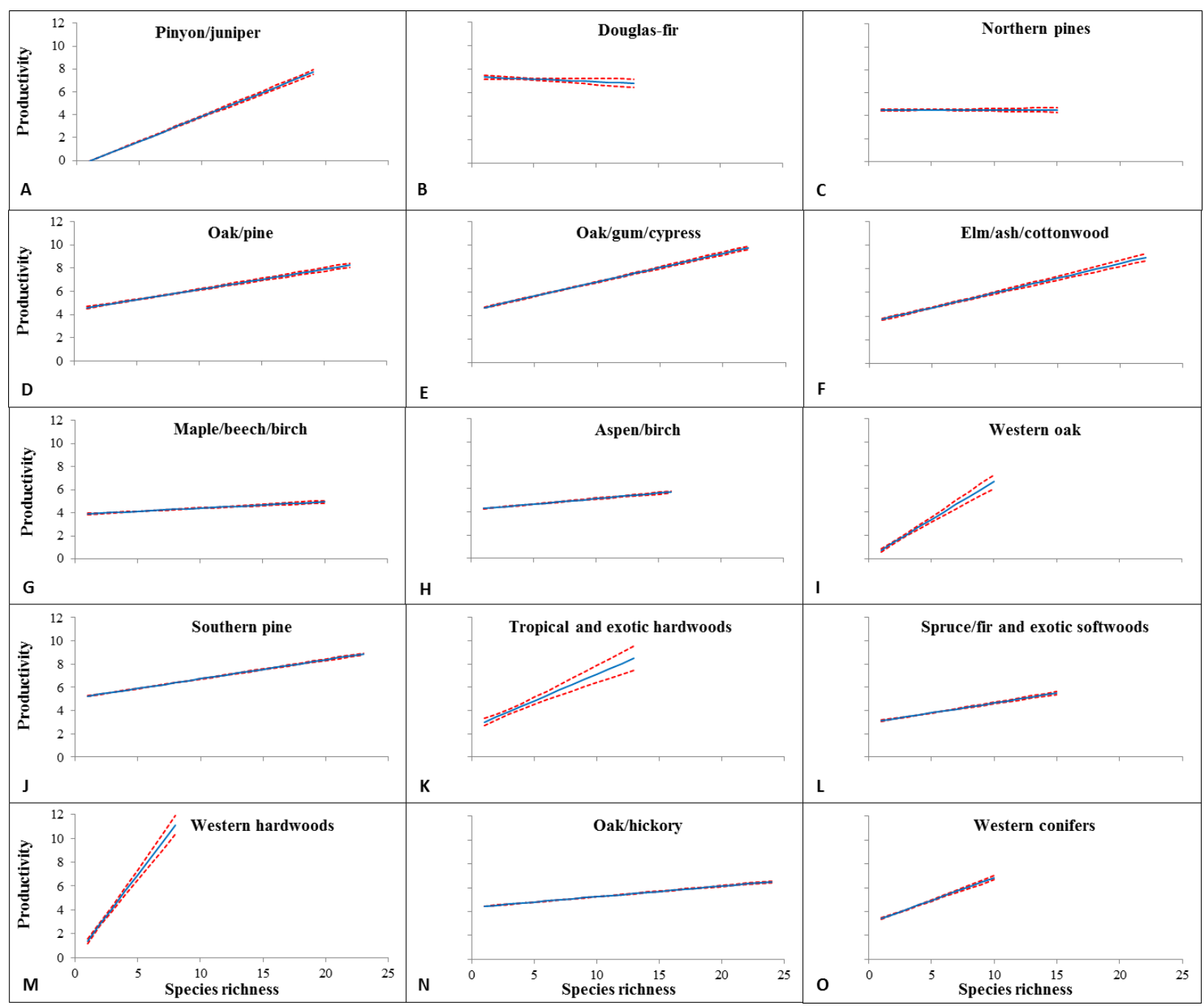

Figure 7. Sensitivity of stand productivity $\left(\mathrm{m}^{3} \mathrm{ha}^{-1} \mathrm{yr}^{-1}\right)$ to species richness for 15 forest types across the 48 contiguous U.S. states and Alaska. Solid lines represents predicted means of different forest types and broken lines $95 \%$ confidence interval of the predicted means, with stand basal area being kept constant at its sample mean. 


\section{Supplemental Material 1}

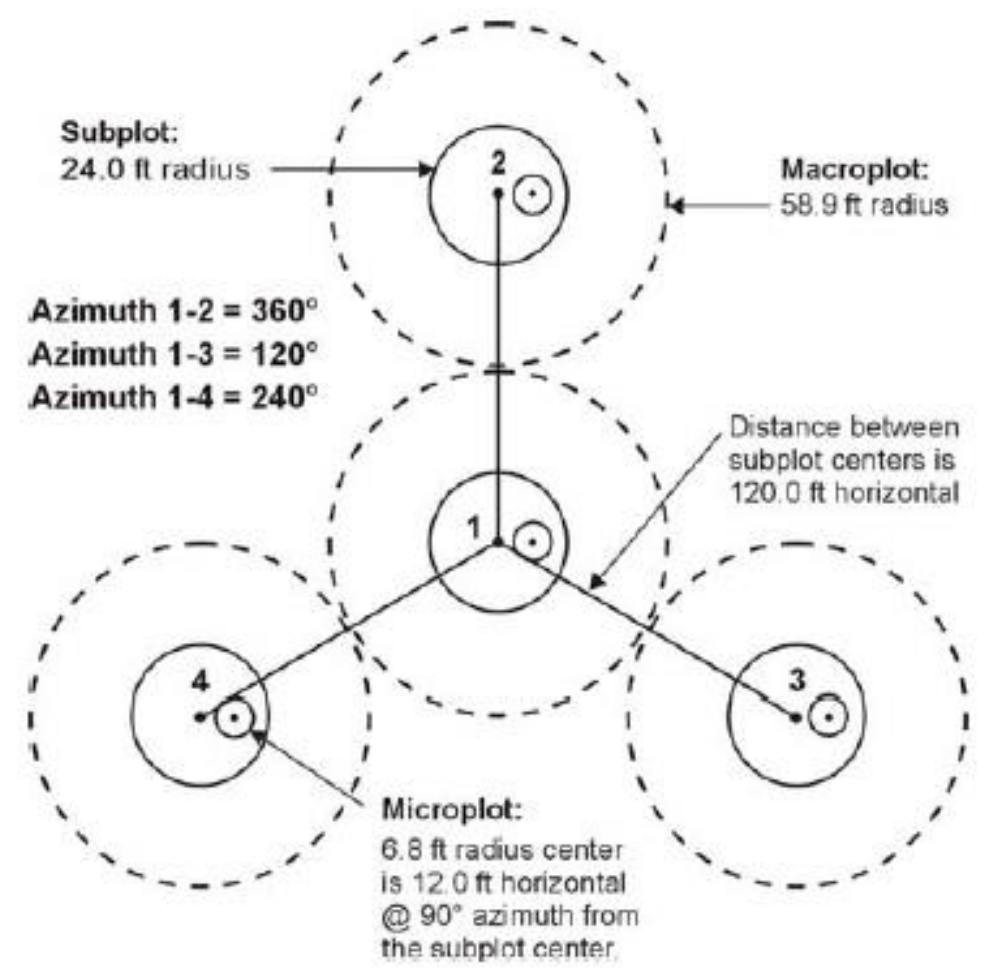

Figure1. Design and layout of an FIA plot (Woudenberg et al. 2011). At the center of the plot cluster is subplot 1 with subplots 2, 3, and 4 surrounding it (Woudenberg et al. 2011).

The FIA program uses a 3-phase sampling scheme (Woudenberg et al. 2011). Phase 1 is used for the purpose of stratification. The FIA program uses stratification to aggregate ground samples into groups so that variance is decreased when stratified estimation methods are used. Every FIA ground plot is assigned to a stratum and the stratum's weight is based on its proportion within the estimation unit. Population totals are estimated based on the sum of the product of the total area, the average of the plot attribute of interest for each stratum, and stratum weight. Each stratum of the estimation unit has an expansion factor that is calculated as the product of stratum weight and total area divided by the amount of phase 2 plots existing in the stratum. 
Phase 2 consists of actual FIA ground plots. These plots may be visited or photo-interpreted. Phase 2 plots cover 0.404686 hectare, although not all trees within the boundaries of the plot are actually measured. These ground plots may be new plots that have never been measured before, or may be re-measurement plots that have been measured previously. While the recent FIA inventories have followed a nationally standard, fixed-radius plot format for sampling trees, there are a variety of variable-radius and fixed-radius subplots that were used to sample trees in older FIA inventories.

Phase 3 is completed for the purpose of measuring forest health indicators. These indicators consist of crown condition, forest soils, ozone injury, vegetation diversity, down woody material, and lichen communities. A $1 / 16^{\text {th }}$ subset of the FIA plot area is used to measure the indicators. Forest health indicators are measured during the leaf-on period which varies by region (Woodall et al. 2011). 
Supplemental Material 2

\section{SUMMARY OF TREE SPECIES DESCRIPTION OF THE CONTIGUOUS UNITED STATES AND ALASKA}




\section{Eastern white pine}

\section{Pinus strobus}

\section{Pinaceae}

\section{Needles:}

5 needles per fascicle, $3-5$ " $(7.6-12.7 \mathrm{~cm})$ long, ever green; blue-green, slender, and flexible, persisting 2-3 years. ${ }^{1}$

\section{Cones:}

4-8" (10.2-20.3cm) long, narrowly cylindrical and often curved, scales are often tipped with white resin.

\section{Twigs:}

Orange-brown, glabrous, and slender.

\section{Buds:}

Terminal and lateral buds in clusters of mostly five, conical with red-brown scales.

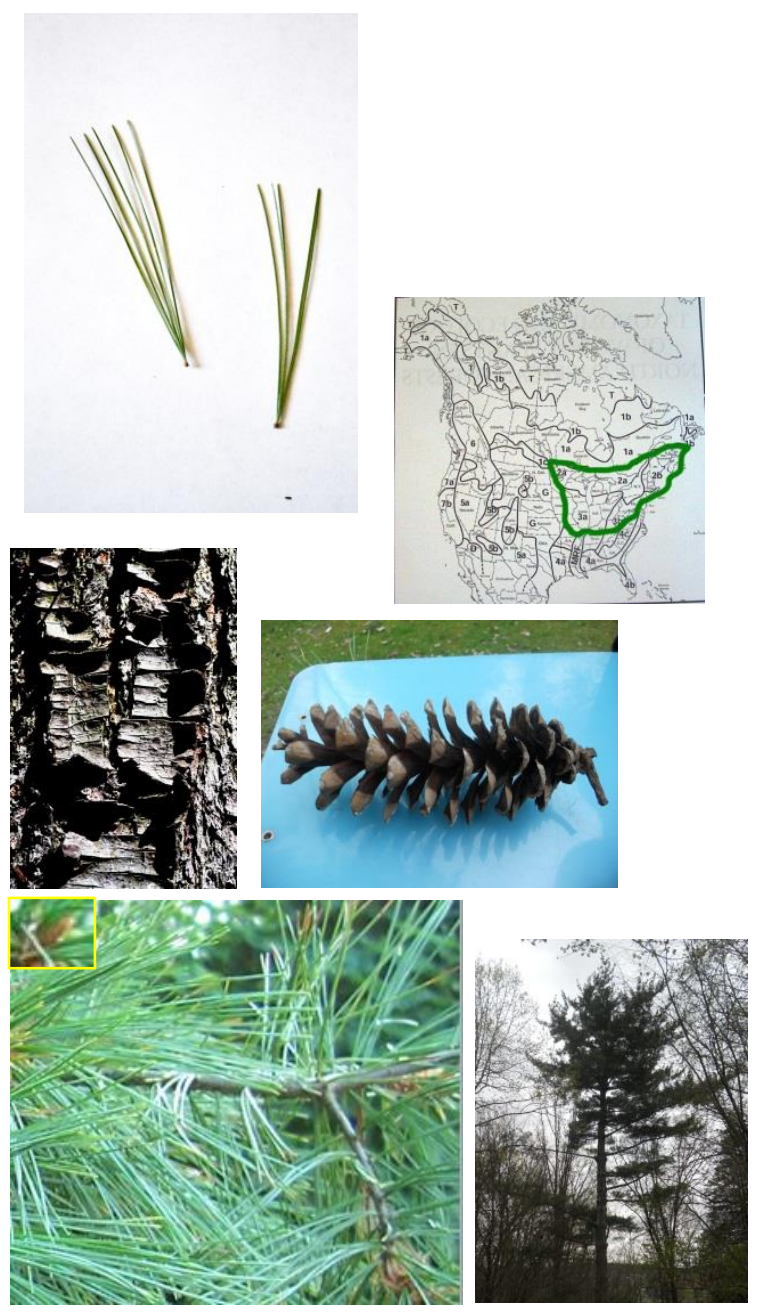

Eastern white pine is a large-size tree growing to 120 feet or more. The branches occur in whorls and extend horizontally, with one tier added annually. The species is the largest conifer of the Northeast and was once prized for ship masts in the Colonial period because of its tall, straight trunks. It is intermediate shade-tolerance, has a rapid growth rate, and is a soft pine. 
Western white pine

\section{Pinus monticola}

Pinaceae

\section{Needles:}

5 needles per fascicle, 2 " to 4 " long. ${ }^{1}$

\section{Cones:}

$5 "$ to 15 ", narrowly cylindrical, yellowish to reddish brown. Cones are stalked with spineless scales. ${ }^{2}$
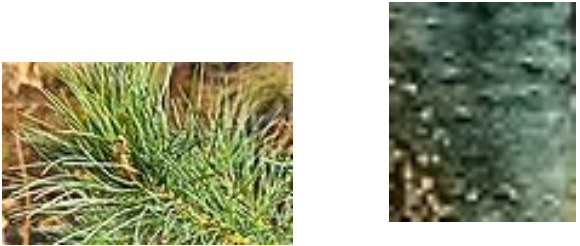

\section{Twigs:}

Moderately slender, greyish brown, glabrous ${ }^{3}$

\section{Buds:}

$1 / 2$ "long, conical, brownish scales. ${ }^{4}$

\section{Bark:}

Similar to Eastern White Pine, dark and blocky. ${ }^{5}$
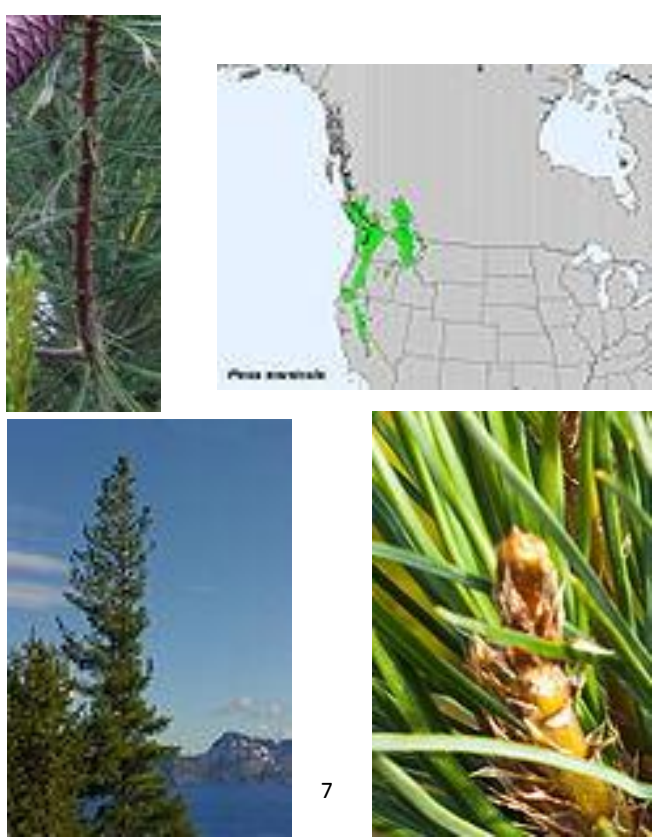

Western white pine has intermediate shade-tolerance, an intermediate growth rate, and is a soft pine. Needles persist for 3 to 4 years give the tree a denser crown than Eastern white pine. Western white pine grows 100 to 175 feet in height and 2 to 5 feet in diameter. The crown consists of pyramidal whorls of horizontal branches.

1: Photo courtesy of http://commons.wikimedia.org/wiki/Pinus_monticola

2: Photo courtesy of http://commons.wikimedia.org/wiki/Pinus_monticola

3: Photo courtesy of http://commons.wikimedia.org/wiki/File:Pinus_monticola_foliage_youngcones.jpg

4: Photo courtesy of http://commons.wikimedia.org/wiki/File:Pinus_monticola_shoot.jpg

5: Photo courtesy of http://commons.wikimedia.org/wiki/Pinus_monticola

6: Image courtesy of http://commons.wikimedia.org/wiki/Pinus_monticola 
Sugar pine

Pinus lambertiana

Pinaceae

\section{Needles:}

5/ fascicle, 2" to 4" long; spirally twisted, bluish green in color, sharp-pointed. Needles persist for 2 to 3 years. $^{1}$

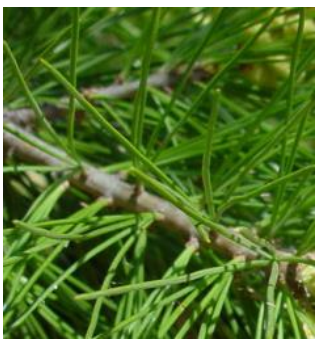

\section{Cones:}

10 " to 26 " long; 4 " to 5 " in diameter when open. Cones are stalked with spineless scales. ${ }^{2}$

\section{Twigs:}

Stout, greyish brown ${ }^{3}$

\section{Buds:}

5/16", oval, brownish, resinous.
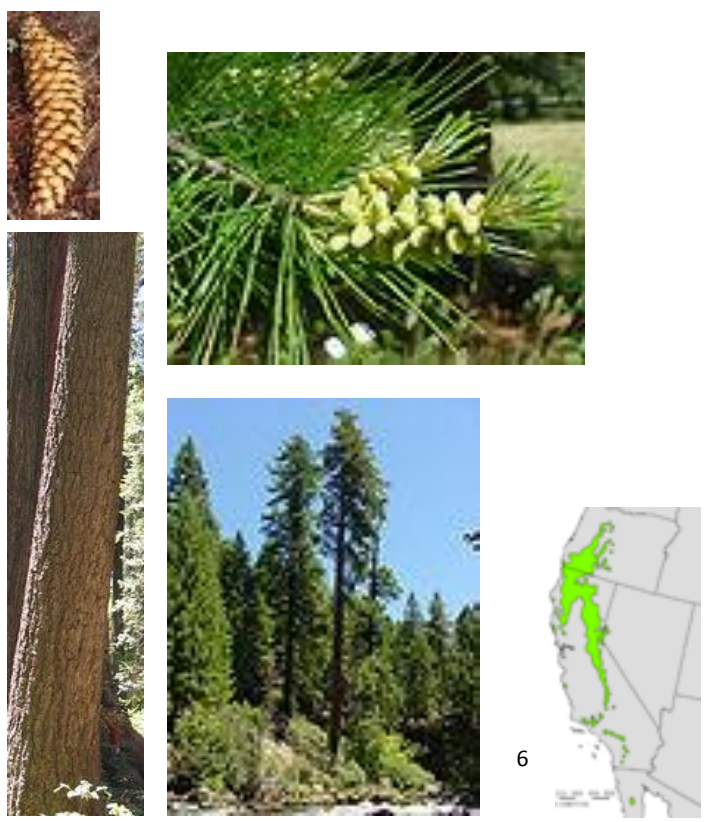

Sugar pine is intermediate in shade-tolerance, has a rapid growth rate, and is a soft pine. Sap contains a sugary substance. Sugar pine is the tallest American pine, reaching 175 to 200 feet in height. Sugar pine attains a diameter of 3 to 5 feet. The pyramidal crown consists of whorls of horizontal branches, some of which are noticeably longer than others.

1: Photo courtesy of http://commons.wikimedia.org/wiki/Pinus_lambertiana

2: Photo courtesy of http://commons.wikimedia.org/wiki/Pinus_lambertiana

3: Photo courtesy of http://commons.wikimedia.org/wiki/File:Pinus_lambertiana_pollencones.jpg

4: Photo courtesy of http://commons.wikimedia.org/wiki/File:CalaverasBigTrees2.jpg

5: Image courtesy of http://commons.wikimedia.org/wiki/Pinus_lambertiana 
Limber pine

Pinus flexilis

Pinaceae

\section{Needles:}

5/ fascicle; 2" long, dark green in color, and crowded at the ends of the branchlets. Needles persist for 5 to 6 years. $^{1}$

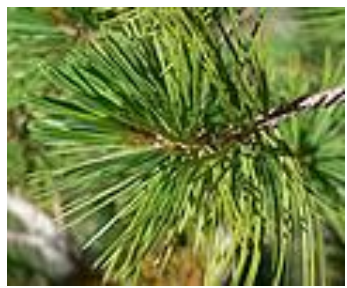

\section{Cones:}

3 " to $10^{\prime \prime}$ cylindrical, resinous. ${ }^{2}$

\section{Twigs:}

Very flexible, green in color, and mostly glabrous. ${ }^{3}$

\section{Buds:}

$3 / 8^{\prime \prime}$ long, sharp pointed. ${ }^{4}$
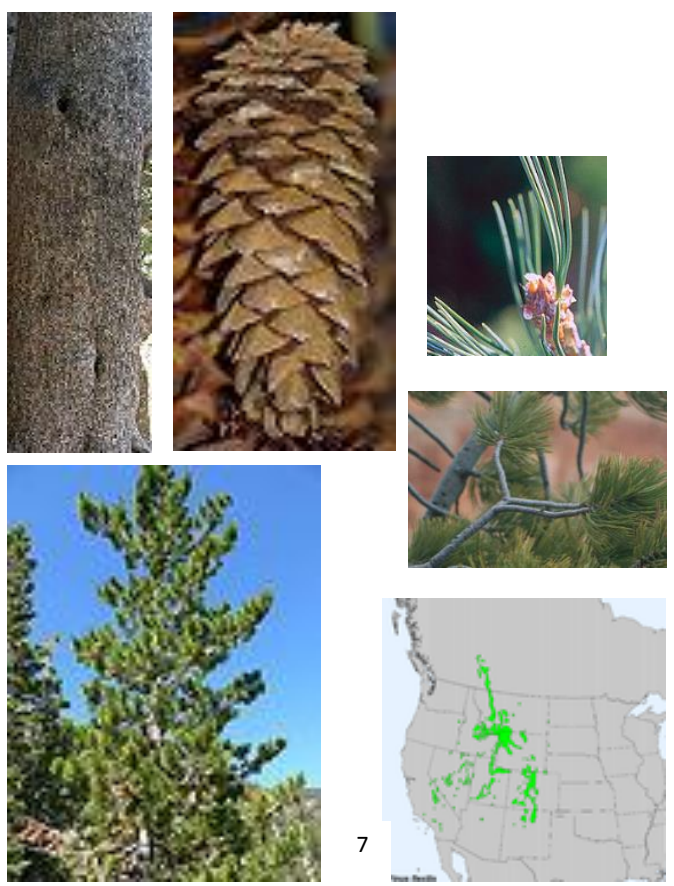

Limber pine is intolerant of shade, has a slow growth rate, and is a soft pine. St_.... become twisted and dwarfed in exposed location. Limber pine grows 25 to 50 feet in height, and 1 to 2 feet in diameter. Growth habit is pyramidal in youth, but becomes rather flat-topped at maturity.

1: Photo courtesy of http://commons.wikimedia.org/wiki/Pinus_flexilis

2: Photo courtesy of http://commons.wikimedia.org/wiki/Pinus flexilis

3: Photo courtesy of http://commons.wikimedia.org/wiki/File:Pinus_flexilis_foliage_Bryce_Canyon.jpg

4: Photo courtesy of http://commons.wikimedia.org/wiki/File:Pinus_flexilis_needles.jpg

5: Photo courtesy of http://commons.wikimedia.org/wiki/File:Pinus_flexilis_Oldtreebark.jpg

6: Image courtesy of http://commons.wikimedia.org/wiki/Pinus_flexilis 
White bark pine

Pinus albicaulis

Pinaceae

Needles:

5 / fascicle, 1 " to $2^{\prime \prime}$ in long, stout and stiff. ${ }^{1}$

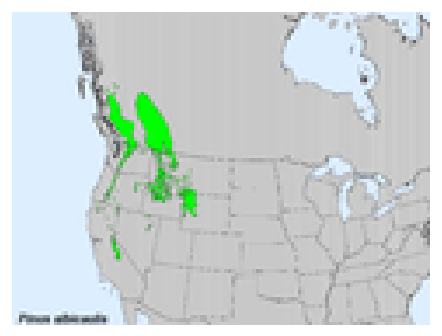

Cones:

$2 \frac{1}{2}$ " long, scales have triangular tips, unlike the cones of other pine species, they disintegrate when mature. ${ }^{2}$

\section{Twigs:}

Greyish brown, stout, persistent scars where needles have dropped. ${ }^{3}$
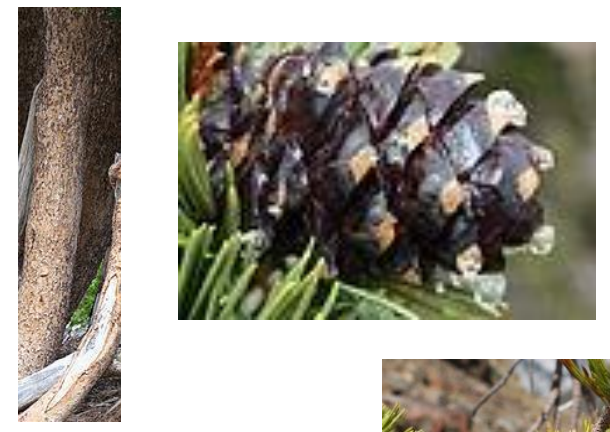

\section{Buds:}

To $2 / 5^{\prime \prime}$, reddish brown, oval.
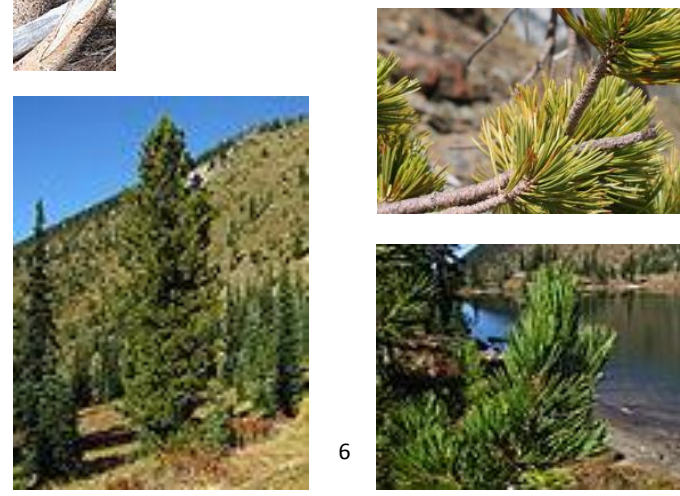

6

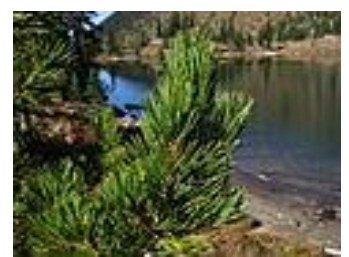

White bark pine is Shade tolerant, has a slow growth rate, and is a soft pine. $\mathrm{U}$....e bark pine reaches 50 to 60 feet in height and 1 to 2 feet in diameter. On poor sites, the species may grow as a sprawling shrub.

\footnotetext{
1: Photo courtesy of http://commons.wikimedia.org/wiki/Pinus_albicaulis

2: Photo courtesy of http://commons.wikimedia.org/wiki/Pinus_albicaulis

3: Photo courtesy of http://commons.wikimedia.org/wiki/File:Pinus_albicaulis_7874.JPG

4: Photo courtesy of http://commons.wikimedia.org/wiki/File:Pinus_albicaulis_Iron_MountainCA1.jpg

5: Image courtesy of http://commons.wikimedia.org/wiki/Pinus_albicaulis 
Red pine

Pinus resinosa

Pinaceae

\section{Needles:}

2/ fascicle; 5-7" long, brittle, dark green in color, sharp pointed.

\section{Cones:}

$1 \frac{1}{2}$ " to $2 \frac{1}{4} 4^{\prime \prime}$ long, light brown in color. Scales are unarmed.

Twigs:

Orange-brown in color, stout and glabrous.

\section{Buds:}

$3 / 4$ " to $1 / 2$ " long, resinous, and sharp pointed. Scales are fringed on margin.
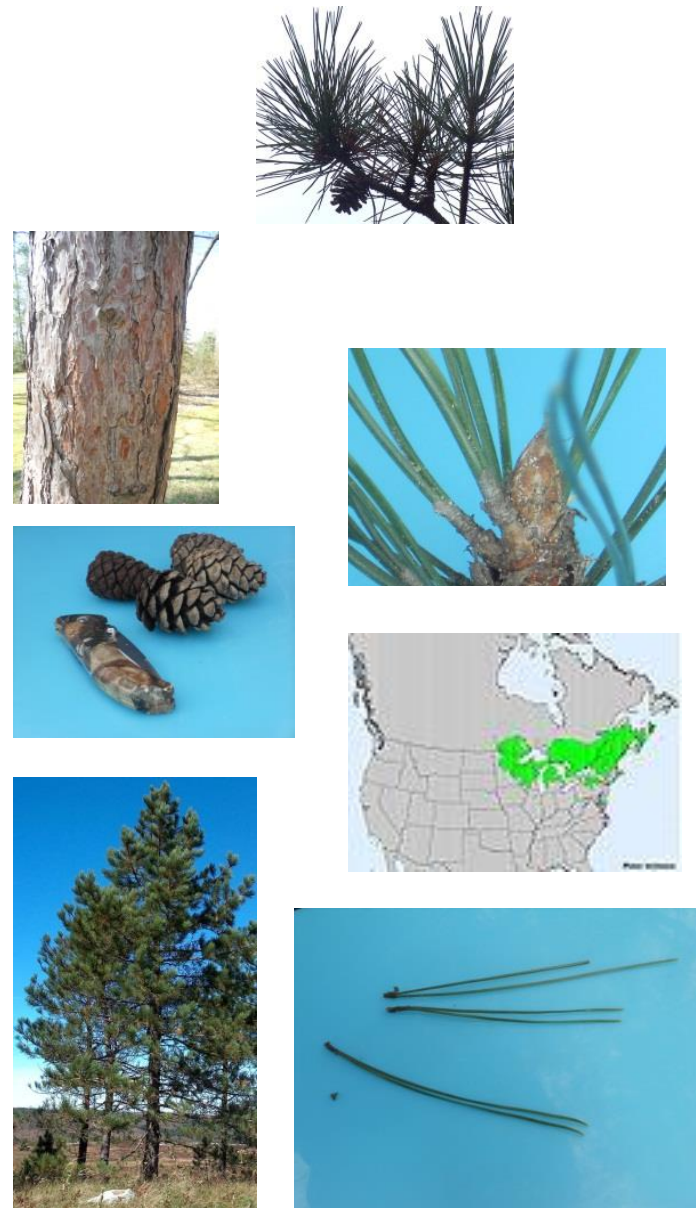

Red pine is intermediate in shade-tolerance and growth rate. Red pine is a hard pine. This species is sometimes called Norway pine. Red pine often invades cutover land. Grows 50 to 100 feet tall, and 2 to 3 feet in diameter. The species is an important timber tree. Red pine grows best in areas having a colder climate. The tree produces one whorl of branches each year. 
Longleaf pine

Pinus palustris

Pinaceae

\section{Needles:}

3 / fascicle; 8" to $18^{\prime \prime}$ long and bright green in color. ${ }^{1}$

\section{Cones:}

$6 "$ to $10^{\prime \prime}$ long, reddish-brown, prickle present on ends of scales.

\section{Twigs:}

Stout; orange-brown. ${ }^{2}$

\section{Buds:}

Large, very conspicuous, silvery fringed scales.

\section{Bark:}

Dark reddish brown in color, with scaly plates. ${ }^{3}$
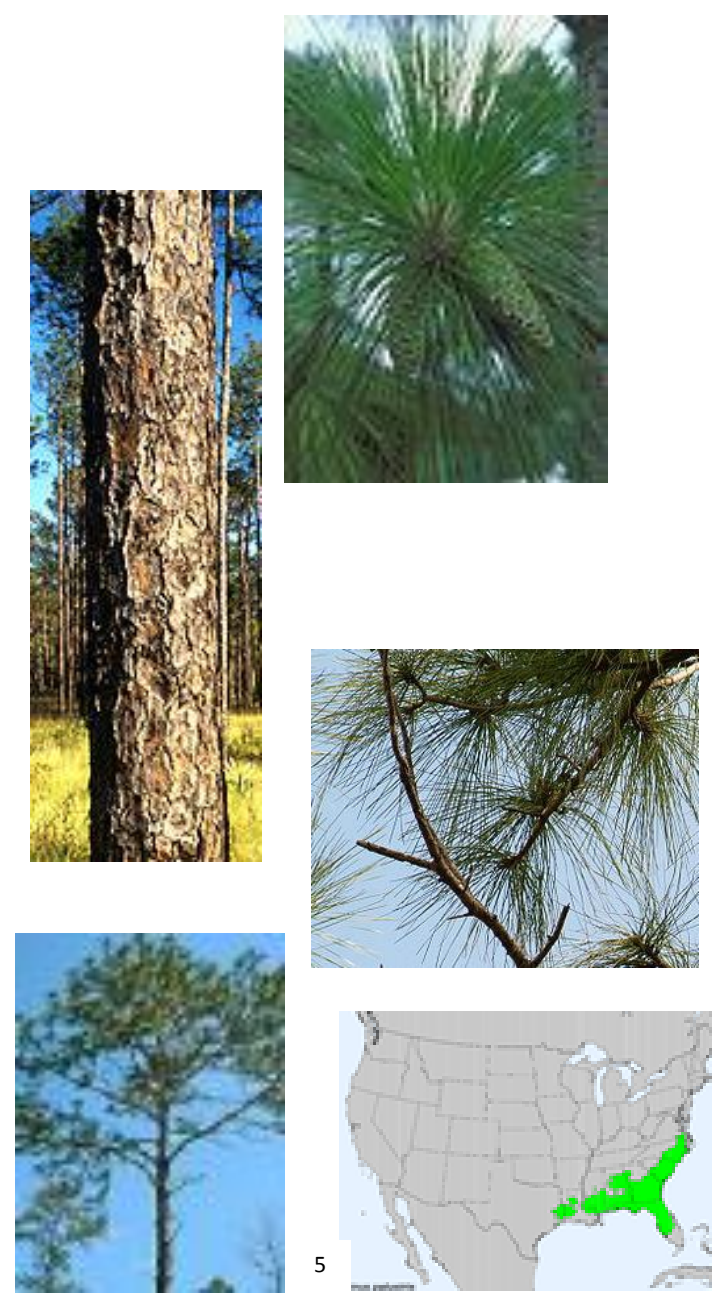

Longleaf pine is intolerant of shade, has a rapid growth rate, and is a hard $\mathrm{F}$ The species is considered a southern pine. Longleaf pine grows to a height of 75 to $120 \mathrm{feet}$, and reaches a diameter of 2 to 2.5 feet. Young longleaf pines grow slowly, form deep roots, and have only a tuft of foliage present near the ground. This stage of development is referred to as the grass stage.

1: Photo courtesy of http://commons.wikimedia.org/wiki/Pinus_palustris

2: Photo courtesy of http://commons.wikimedia.org/wiki/File:Cedar_waxwings_02.JPG

3: Photo courtesy of http://commons.wikimedia.org/wiki/File:Pinus_palustris_USDAFS.jpg

4: Image courtesy of http://commons.wikimedia.org/wiki/Pinus_palustris 
Slash pine

Pinus elliottii

Pinaceae

\section{Needles:}

2 or 3 / fascicle, 7" to $10^{\prime \prime}$ long, and dark bluish green in color. ${ }^{1}$

\section{Cones:}

3" to 6" long, stalked, and chestnut brown in color. Prickles are present at the ends of scales. ${ }^{2}$

\section{Twigs:}

Orange-brown in color. ${ }^{3}$

\section{Buds:}

$4 / 5^{\prime \prime}$, silvery grey brown in color, cylinder shaped. ${ }^{4}$
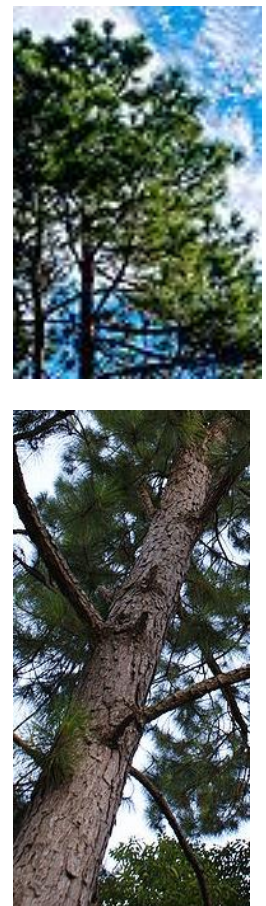
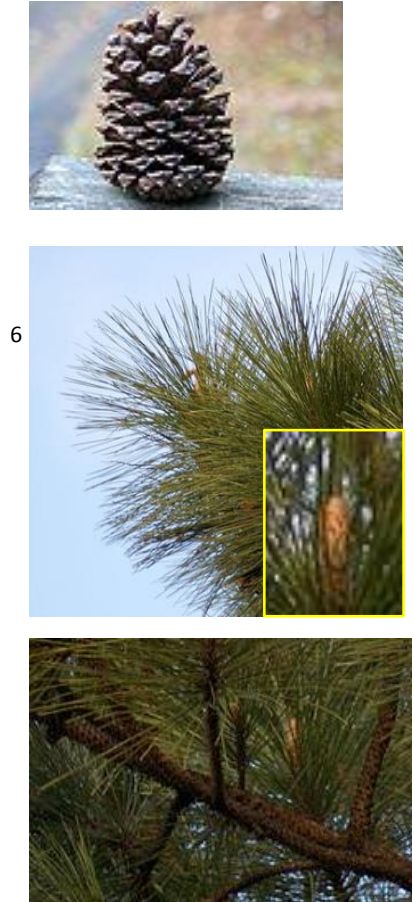

Slash pine is intolerant of shade, has a rapid growth rate, and is a hard pine. The species is considered a southern pine, and is the fastest growing of all the southern pines. Slash pine grows 80 to 100 feet tall, and reaches 2 to 3 feet in diameter. Slash pine has a dense rounded crown. It is an important timber tree.

\footnotetext{
1: Photo courtesy of http://commons.wikimedia.org/wiki/File:Pinus_elliottii_foliage_Georgia.jpg

2: Photo courtesy of http://commons.wikimedia.org/wiki/Pinus_elliottii

3: Photo courtesy of http://commons.wikimedia.org/wiki/File:Pinus_elliottii_foliage_Georgia.jpg

4: Photo courtesy of http://commons.wikimedia.org/wiki/File:Pinus_elliottii_foliage_Georgia.jpg 
Shortleaf pine

Pinus echinata

Pinaceae

\section{Needles:}

Usually 2, sometimes 3 / fascicle; 3" to 5" long, yellowgreen in color. ${ }^{1}$

\section{Cones:}

$1 \frac{1 / 2}{\prime \prime}$ to $2 \frac{1}{2 \prime}$, ovoid to conical; reddish-brown. Prickles at the ends of scales curve towards the base of the cone; deciduous.

\section{Twigs:}

First green and fringed w/purple; eventually reddish brown. $^{2}$

\section{Buds:}

$1 / 4 "$ long, scales closely appressed, and brown in color.
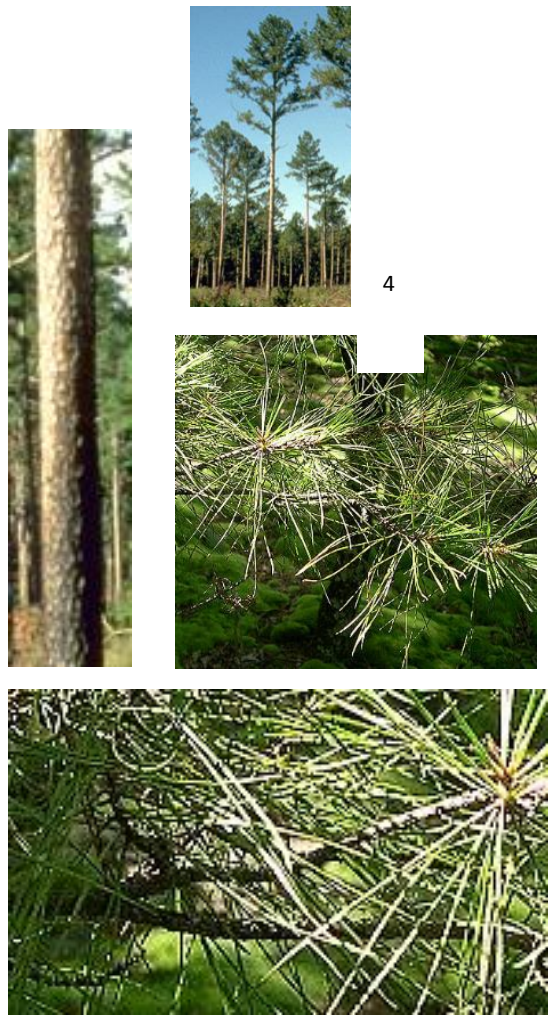

Shortleaf pine is intolerant of shade, has a moderate to rapid growth rate, and is a hard pine. The species is considered a southern pine. Shortleaf pine reaches a height of 80 to 100 feet and a diameter of 2 to 3 feet. The species forms a deep taproot. Shortleaf pine is an important timber tree and typically grows in light dry soils.

1: Photo courtesy of http://commons.wikimedia.org/wiki/File:Pinus_echinata_sapling_Shawnee_National_Forest.jpg 
Loblolly pine

Pinus taeda

Pinaceae

\section{Needles:}

3 / fascicle; 6" to 9" long, yellowish green in color, resinous, and stiff. ${ }^{1}$

\section{Cones:}

3" to 6" long, conical (armed with stout sharp spine). Yellowish brown when young, becoming grey with age. $^{2}$

\section{Twigs:}

Yellow-brown or reddish brown, slender, glabrous.

\section{Buds:}

$1 / 4$ " to $1 / 2$ " long, reddish brown in color, scales fringed and often reflexed.
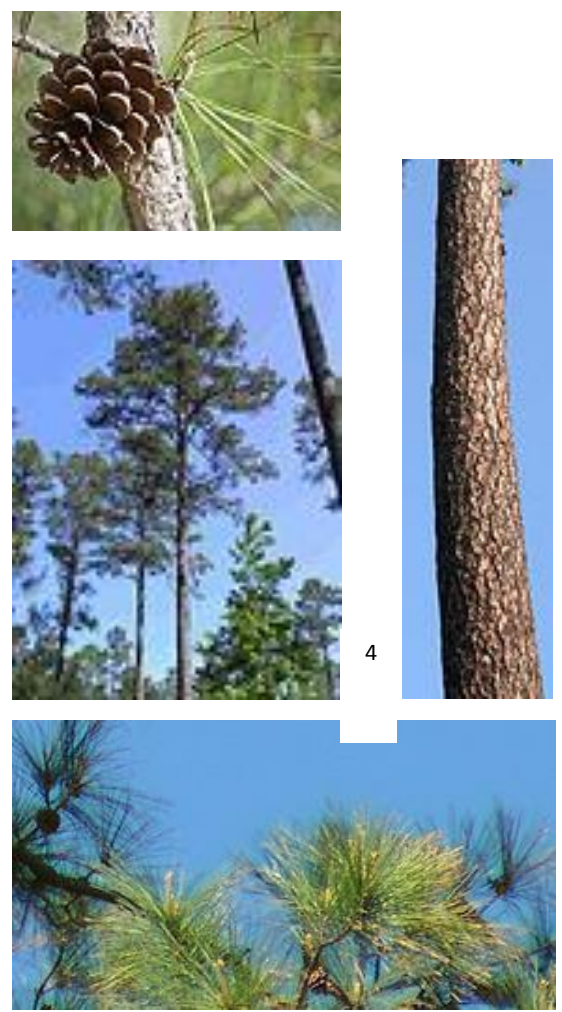

Loblolly pine is moderately tolerant of shade, has a rapid growth rate, and is a hard pine. The species is considered a southern pine. It grows 90 to 100 feet in height and reaches 2 to 3 feet in diameter. Crown is relatively dense. Loblolly pine is the leading commercial timber tree in the southeastern U.S. The species is tolerant of a large range of site conditions. Develops a clear bole with age. 
Pitch pine

Pinus rigida

Pinaceae

\section{Needles:}

3/fascicle; 3" to 5" long, stiff, twisted, and yellowgreen in color. Needles are often present in clusters on the trunk and large limbs.

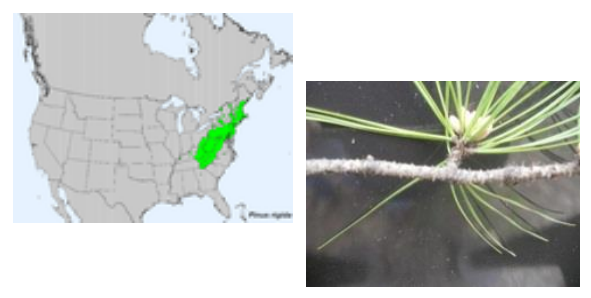

\section{Cones:}

2 " to $3 \frac{1}{2 \prime}$, nearly sessile, ovoid. Scales are thick and have prickles at the ends. Bases of cones are flat.

\section{Twigs:}

Brown to orange in color, stout.

\section{Buds:}

$3 / 4 "$ long, resinous, and reddish brown in color.
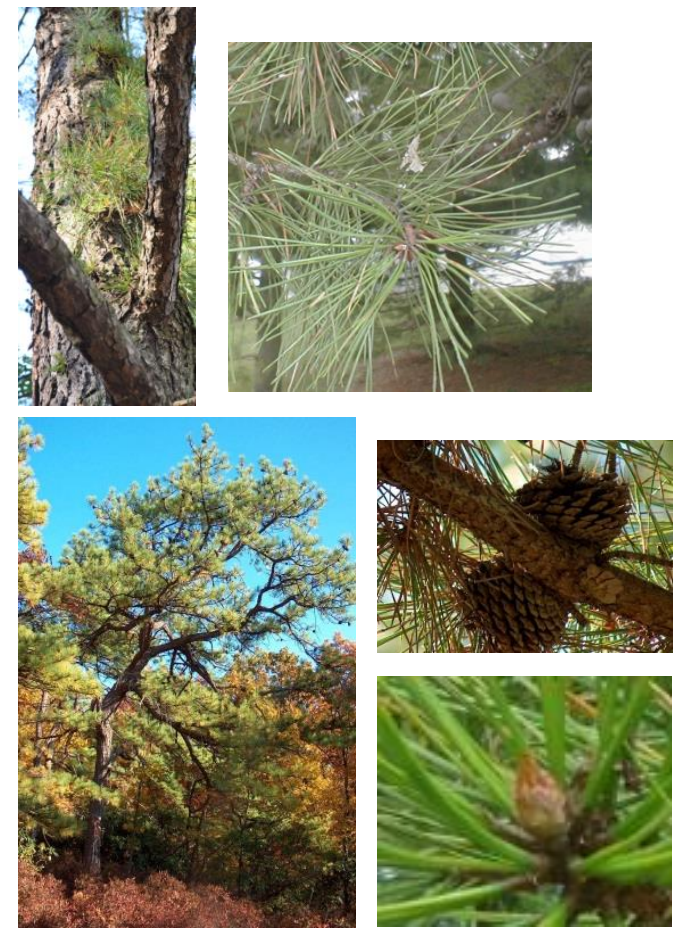

Pitch pine is intolerant of shade, has a moderate growth rate, and is a hard pine. It grows to a height of 50 to 60 feet, and reaches a diameter of 1 to 2 feet. It generally grows on poor sites and often has a rather coarse growth form. Pitch pine typically has many epicormic shoots along the trunk and limbs, hence, the clusters of needles present along the tree's main bole and limbs. 
Virginia pine

Pinus virginiana

Pinaceae

\section{Needles:}

$1 \frac{1}{2}$ " to $2 \frac{1}{2}$ " long, $2 /$ fascicle, twisted, and yellowgreen in color.

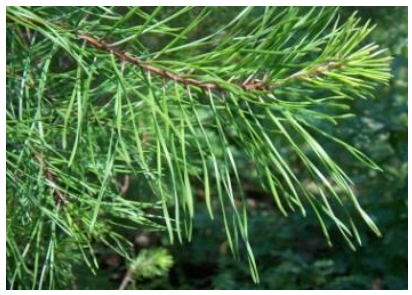

\section{Cones:}

$1 \frac{1}{2}$ " to $2 \frac{1}{2}$ " usually sessile, very sharp prickles at ends of scales. Many, many cones typically present on any given tree.

\section{Twigs:}

Green turning purplish, glaucous.

\section{Buds:}

$1 / 3^{\prime \prime}$ to $1 / 2^{\prime \prime}$ long, resinous, sharply pointed.
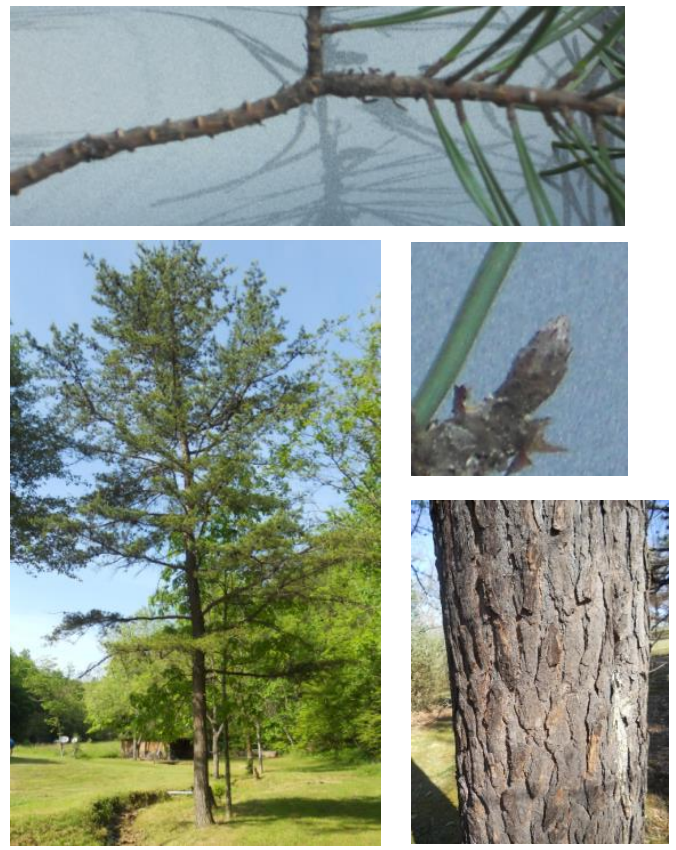

Virginia pine is intolerant of shade, has a moderate growth rate, and is a hard pine. It grows to a height of 40 to 60 feet, and attains a diameter of 1 to 1.5 feet. Virginia pine is often grown for Christmas trees in the southern states. A good identification feature of this species is the abundance of cones present, even persisting on dead branches. The crown may become flat topped if grown in the open. Virginia pine is susceptible to wind throw in exposed locations. 
Lodgepole pine

\section{Pinus contorta}

Pinaceae

\section{Needles:}

2 / fascicle; 1" to 3" long, twisted, dark green in color. Needles remain on the tree for three years or more. ${ }^{1}$

\section{Cones:}

$3 / 4$ " to 2 ", variably serotinous. A stiff prickle is present at the ends of scales. ${ }^{2}$

\section{Twigs:}

Moderately stout, orangish brown. ${ }^{3}$

\section{Buds:}

$2 / 5^{\prime \prime}$, oval, somewhat resinous, brownish in color. ${ }^{4}$

\section{Bark:}

Black to light brown, and scaly. ${ }^{5}$
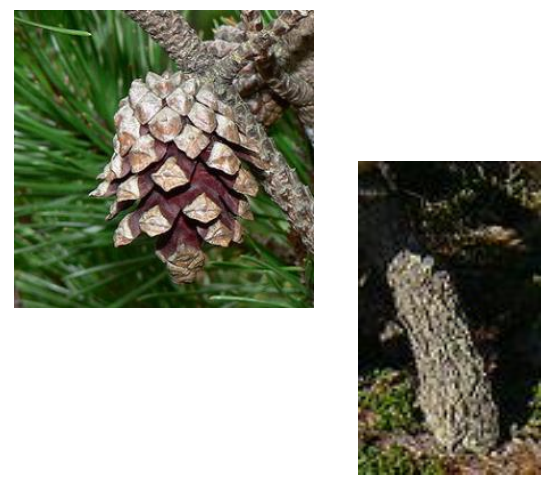

\section{Distribution in North America:}

Native to western North America. ${ }^{6}$
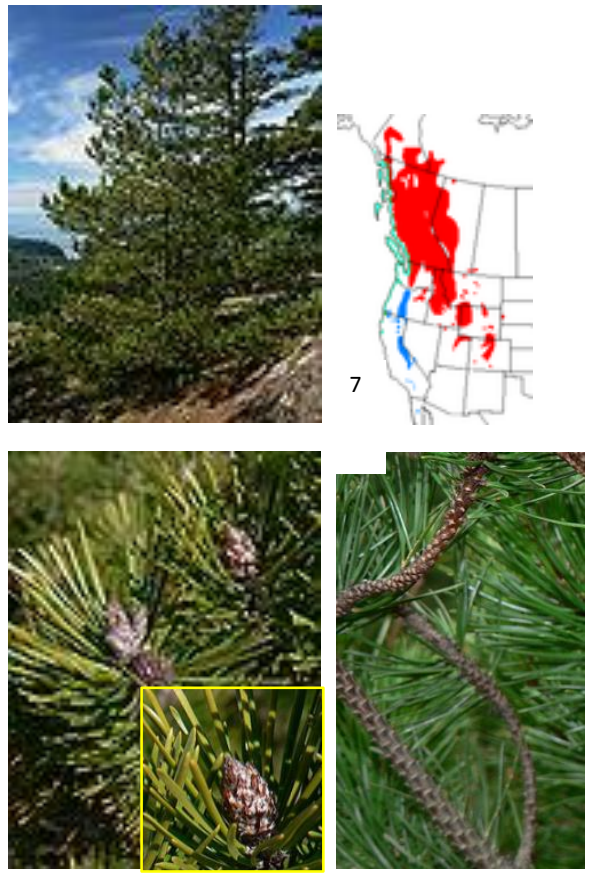

Lodgepole pine is intolerant of shade, has a slow growth rate, and is a hard pine. Regeneration of this species is very dependent on fire. Composed of three to four subspecies. The subspecies Latifolia reaches a height of 75 to 80 feet, and a diameter of 1 to 3 feet. Once used by Native Americans for dwelling poles. 
Jack pine

Pinus banksiana

Pinaceae

\section{Needles:}

$3 / 4^{\prime \prime}$ to $1 \frac{1}{2 \prime}, 2$ / fascicle, frequently twisted, olive green in color. Needles persist for 2 to 3 years. ${ }^{1}$

\section{Cones:}

$1 \frac{1}{2}$ " to $2^{\prime \prime}$ long, sessile, light brown, serotinous and strongly asymmetrical. ${ }^{2}$

\section{Twigs:}

Slender, flexible, and dark purple in color. ${ }^{3}$

\section{Buds:}

$1 / 8^{\prime \prime}$ to $1 / 4^{\prime \prime}$ long, resinous, and dark brown in color. ${ }^{4}$
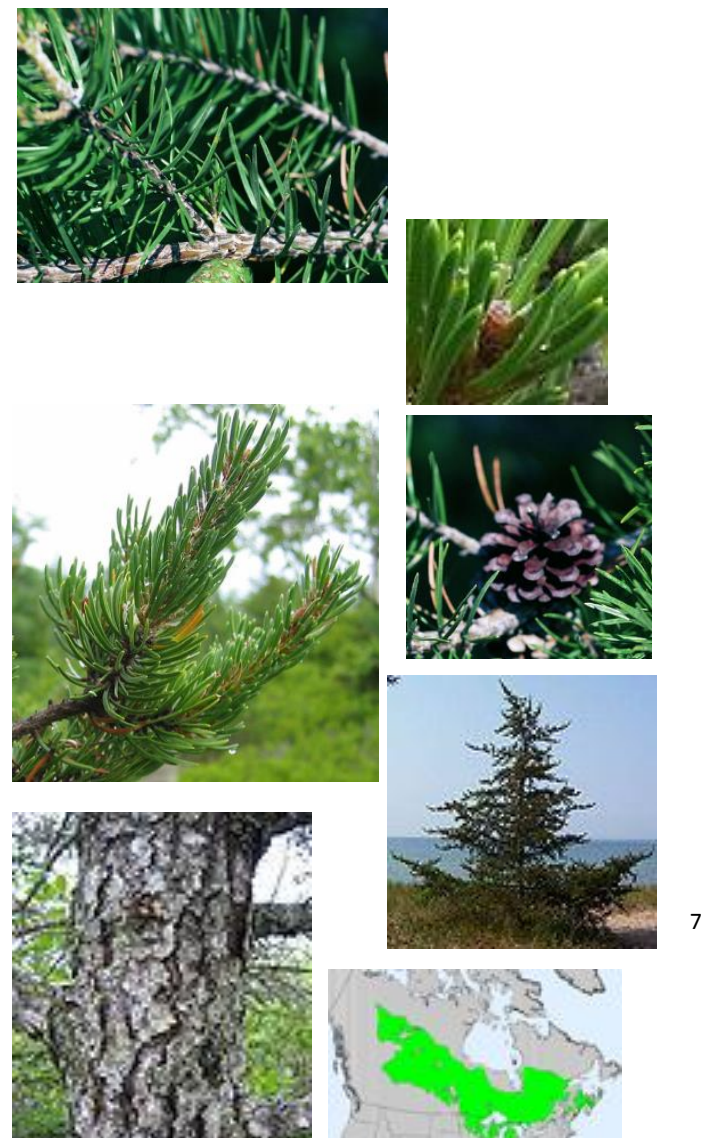

Jack pine is very intolerant of shade, has a rapid growth rate, and is a hard pine. It grows 70 to 80 feet tall, and reaches a diameter of 1 to 1.5 feet. It typically grows in poor soils and has a rather ragged appearance. It grows the farthest north of any North American pine species.

1: Photo courtesy of http://commons.wikimedia.org/wiki/File:Pinus_banksiana_pollen_cones.jpg

2: Photo courtesy of http://commons.wikimedia.org/wiki/File:Pinus_banksiana_cones.jpg

3: Photo courtesy of http://commons.wikimedia.org/wiki/File:Pinus_banksiana_cones.jpg

4: Photo courtesy of http://commons.wikimedia.org/wiki/File:Pinus_banksiana_foliagecone.jpg

5: Photo courtesy of http://commons.wikimedia.org/wiki/Pinus_banksiana

6: Image courtesy of http://commons.wikimedia.org/wiki/Pinus_banksiana 
Ponderosa pine

Pinus ponderosa

Pinaceae

\section{Needles:}

5 " to 11 ", 3 or $2 /$ fascicle, flexible, can be dark or yellowish green in color.

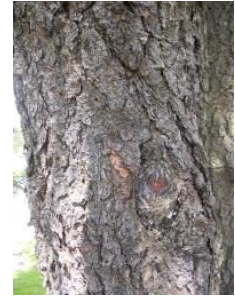

\section{Cones:}

3" to 6" long, ovoid to ellipsoid, sessile, solitary or clustered. Stiff prickle present at the ends of scales.

\section{Twigs:}

Stout, turpentine odor, glabrous. Orange-brown at first, but become almost black at maturity.

\section{Buds:}

4/5" long, covered with resin, reddish brown.
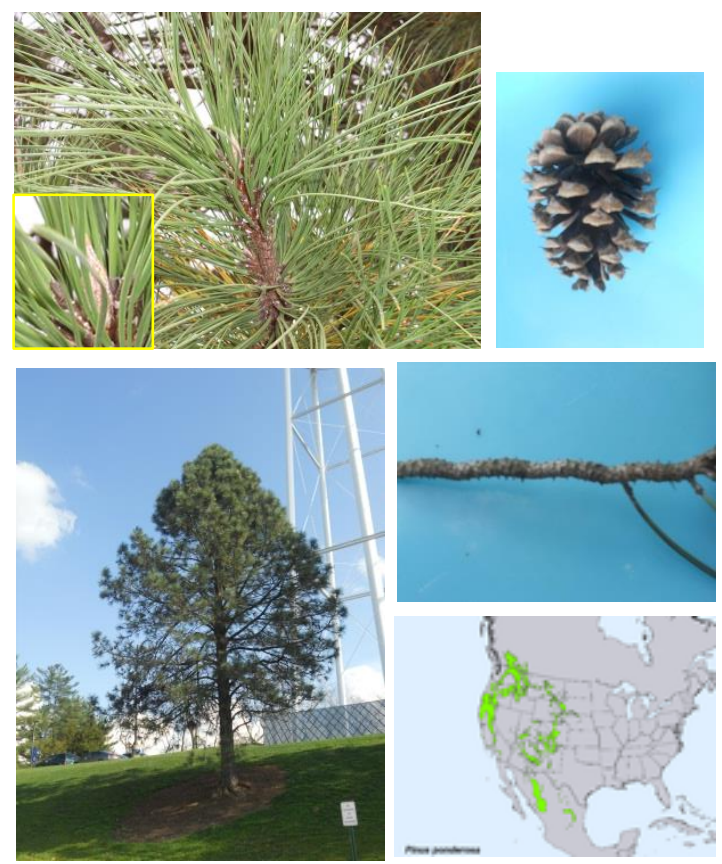

Ponderosa pine is intolerant of shade, has a rapid growth rate, and is a hard pine. It grows to a height of 150 to 180 feet, and attains a diameter of 3 to 4 feet. It typically has an open crown. Ponderosa pine is an important timber tree in the western United States. Ponderosa pine will grow on very different sites, from poor to excellent. 
Jeffery pine

Pinus jeffreyi

Pinaceae

\section{Needles:}

5" to $10^{\prime \prime}$ long, 2 or 3 / fascicle; twisted, blue-green. Needles often persist up to nine years on branches. ${ }^{1}$

\section{Cones:}
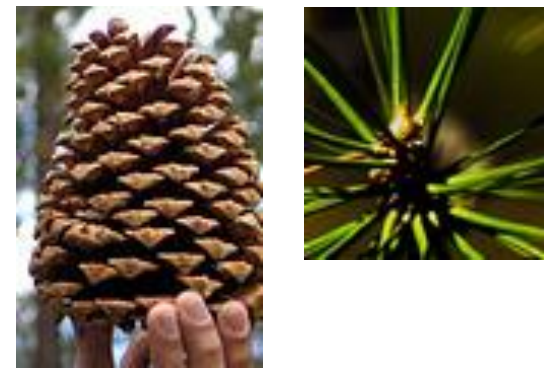

$5 "$ to $15^{\prime \prime}$ long, ovoid, chestnut brown. Prickles present on scales. ${ }^{2}$

\section{Twigs:}

Brown, tinged with purple, stout. ${ }^{3}$

\section{Buds:}

$1 "$, light brown, oval, ends of scales fringed. ${ }^{4}$
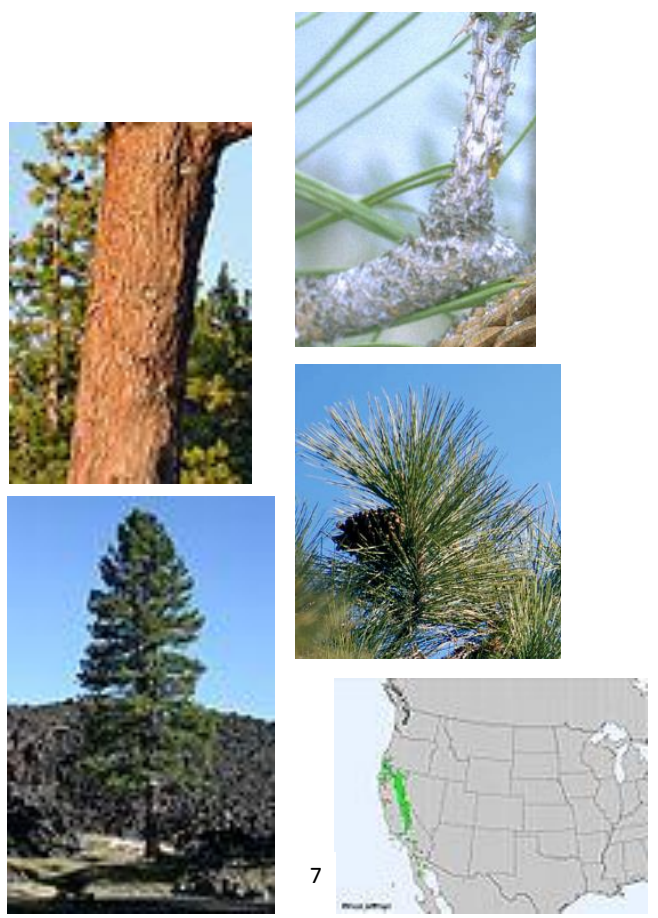

Jeffery pine is Intolerant of shade, has a moderate growth rate, and is a har, , ne. It can grow 90 to 100 feet in height on a good site. It is typically smaller in size than Ponderosa pine, and grows at higher elevations. Due to the long persisting needles, the tree often has a more dense crown than Ponderosa pine. Will tolerate climate extremes.

1: Photo courtesy of http://commons.wikimedia.org/wiki/File:Pinus_jeffreyi_cones_BigBearLake.jpg

2: Photo courtesy of http://commons.wikimedia.org/wiki/Pinus_jeffreyi

3: Photo courtesy of http://commons.wikimedia.org/wiki/File:Pinus_jeffreyi_BLM1.jpg

4: Photo courtesy of http://commons.wikimedia.org/wiki/File:Jeffneedles.jpg

5: Photo courtesy of http://commons.wikimedia.org/wiki/File:Pinus_jeffreyi_TahoeNV.jpg 


\section{Grey pine, Digger pine}

\section{Pinus sabiniana}

\section{Pinaceae}

\section{Needles:}

3/fascicle; 8 " to $12^{\prime \prime}$ long, gray-green; stiff. $^{1}$

\section{Cones:}

5-14" long, heavy, reddish brown scales. Scales end in a triangular shaped claw. ${ }^{2}$

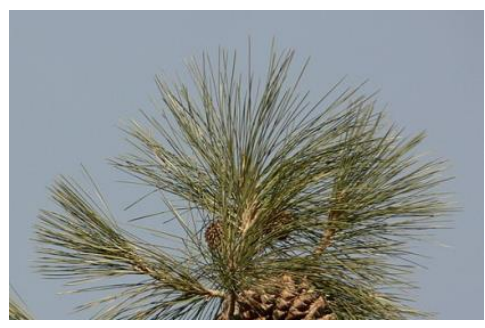

\section{Twigs:}

Moderately stout, rough, grey in color. ${ }^{3}$

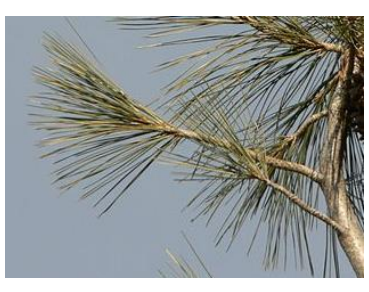

Buds:

$2 / 5^{\prime \prime}$, resinous, brown, oval.

\section{Bark:}

Dark brown, scaly. ${ }^{4}$
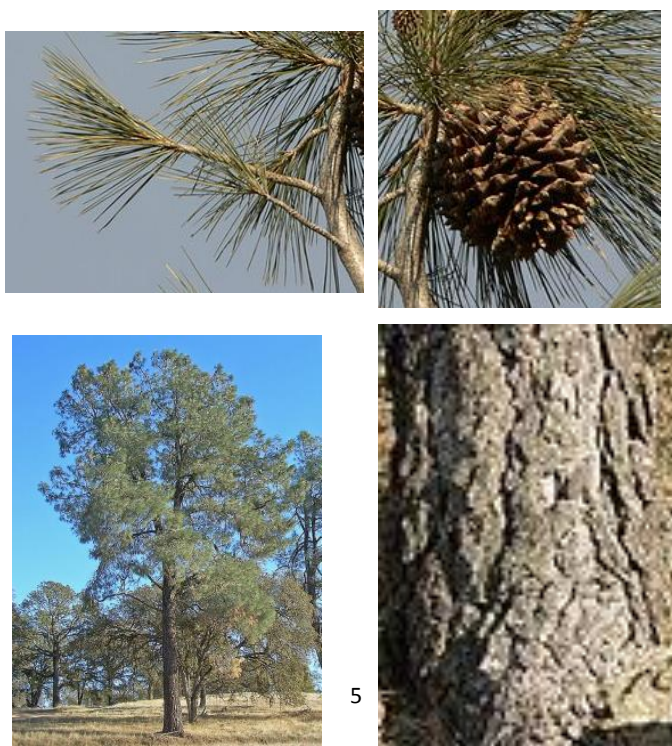

Digger pine is intolerant of shade, has a slow growth rate, and is a hard pine. It gruws 40 to 60 feet in height, and attains a diameter of 1 to 2 feet. It is common for Digger pine to have a forked trunk. The seeds of Digger pine were once part of the Native American's diet. 
Monterey pine

Pinus radiata

Pinaceae

\section{Needles:}

3/fascicle (occasionally 2) 3-6" long; dark green; slender, flexible. ${ }^{1}$

\section{Cones:}

3" to 7" long, extremely asymmetrical, serotinous. Light brown in color, small prickle present at ends of scales. $^{2}$

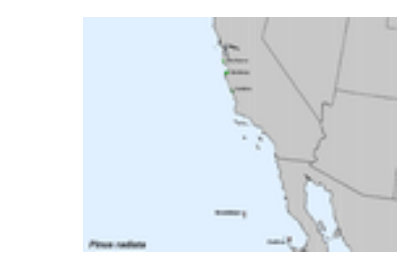

\section{Twigs:}

Slender, greyish, and rough. ${ }^{3}$
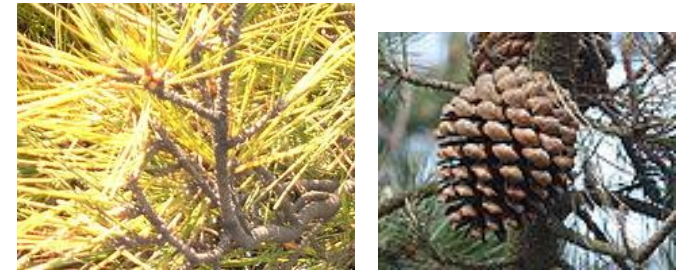

\section{Buds:}

$2 / 5^{\prime \prime}$, reddish brown, resinous,
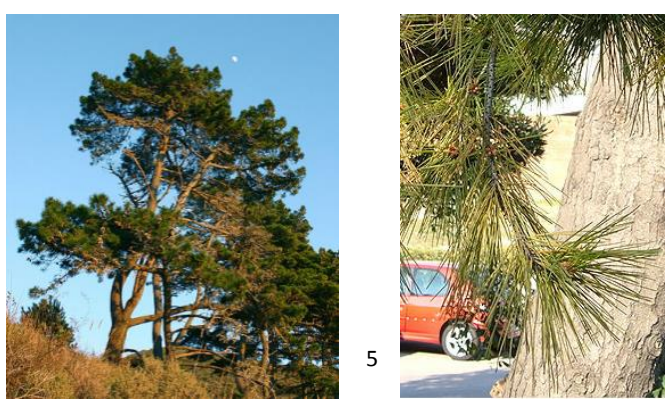

Monterey pine is intermediate in shade tolerance, has a rapid growth rate, and is $n$. nard pine. It grows 40 to 100 feet in height, and reaches a diameter of 1 to 3 feet. It has a dense crown. In its native range, the tree is of little commercial value. However, it is used extensively in other locations such as New Zealand and Australia where it is grown in plantations to produce timber.

1: Photo courtesy of http://commons.wikimedia.org/wiki/File:Pinus_radiata_leaves.JPG

2: Photo courtesy of http://commons.wikimedia.org/wiki/Pinus_radiata

3: Photo courtesy of http://commons.wikimedia.org/wiki/File:Pinus_radiata_fruit.JPG

4: Image courtesy of http://commons.wikimedia.org/wiki/Pinus_radiata 
Eastern larch, Tamarack

Larix laricina

Pinaceae

\section{Needles:}

$3 / 4$ to $1 \frac{1}{2}$ ", blue green, 3 -angled, flat, and deciduous.

Fall color is yellow. ${ }^{1}$

\section{Cones:}

Oblong, upright, bracts shorter than scales; $1 / 2-3 / 4^{\prime \prime} .2$

\section{Twigs:}

Glabrous, thin, yellowish brown to reddish brown in color. Small spur shoots abundant along twigs. ${ }^{3}$

\section{Buds:}

Globose, dark red, somewhat resinous. ${ }^{4}$
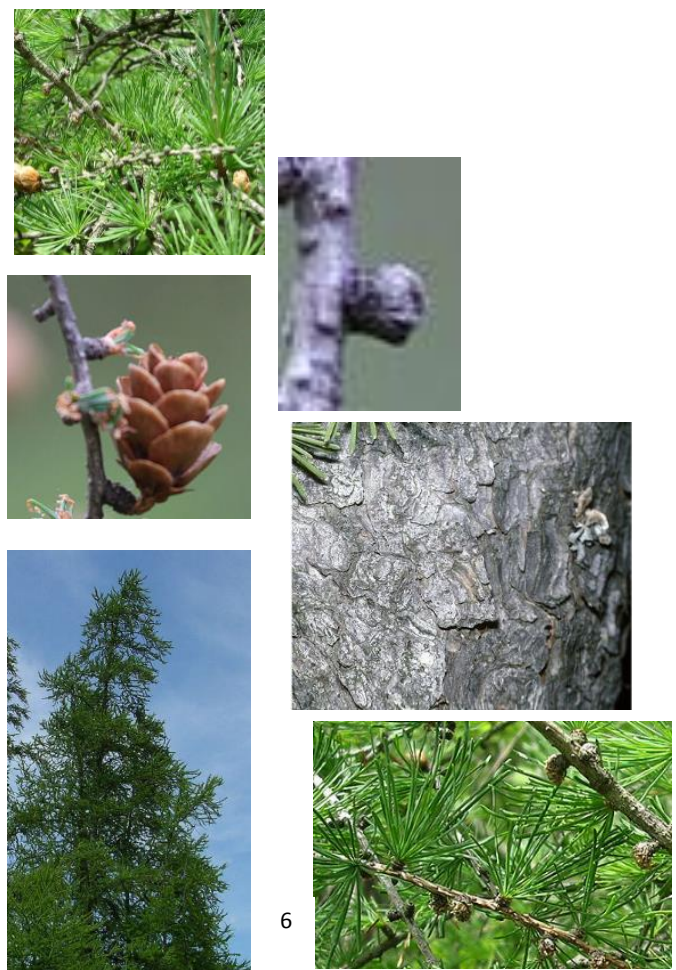

Eastern larch is intolerant of shade, and has a rapid growth rate. It grows $4 \mathrm{C}$ iv 80 feet in height and reaches a diameter of 1 to 2 feet. Often grows on cold, poorly drained sites. It does not perform well on dry, hot sites.

1: Photo courtesy of http://commons.wikimedia.org/wiki/File:Larix_laricina_Volo_Bog_2.jpg

2: Photo courtesy of http://commons.wikimedia.org/wiki/File:Larix_laricina_cones_Cormac_Ontario.jpg

3: Photo courtesy of http://commons.wikimedia.org/wiki/File:Larix_laricina_Volo_Bog_2.jpg

4: Photo courtesy of http://commons.wikimedia.org/wiki/File:Larix_laricina_cones_Cormac_Ontario.jpg

5: Photo courtesy of http://commons.wikimedia.org/wiki/File:Larix_laricina_bark.jpg

6: Photo courtesy of http://commons.wikimedia.org/wiki/File:Larix_laricina_Volo_Bog_1.jpg 
Western larch

Larix occidentalis

Pinaceae

\section{Needles:}

$1 "$ to $13 / 4^{\prime \prime}$, green, 3-angled, deciduous.

Cones:

Oblong, 1" $-1 \frac{12}{2 \prime}$, purplish to reddish brown, typically wider than long. ${ }^{1}$

\section{Twigs:}

Orange brown in color, slender. Small spur-like shoots abundant.

\section{Buds:}

Dark brown and typically pubescent.
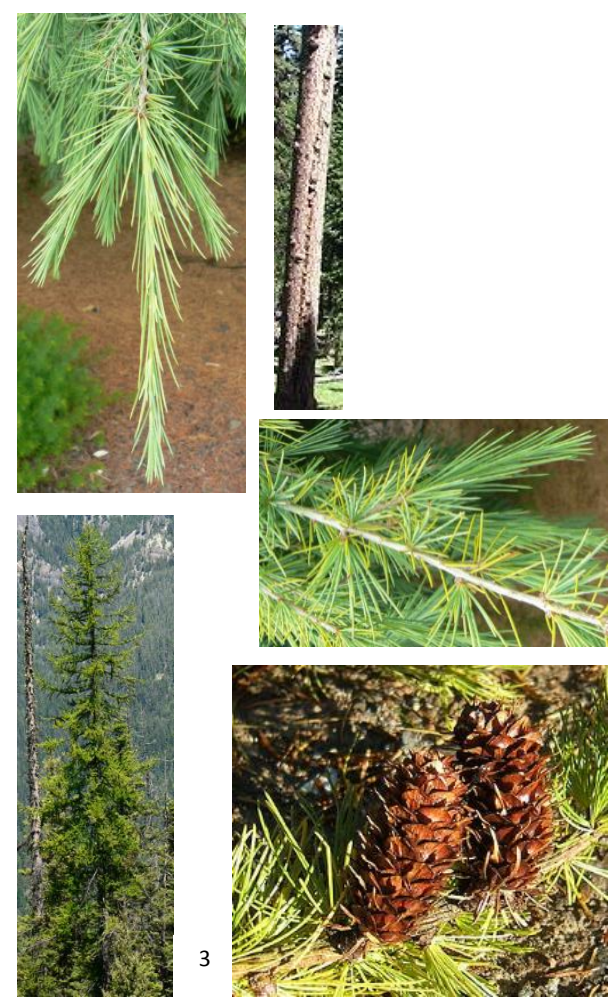

Western larch is intolerant of shade and has a rapid growth rate. It g. . ...s up to 150 feet tall and attains a diameter of 3 to 4 feet. It grows best on moist slopes, but will tolerate dry sites as well. It is an important timber tree. 


\section{Needles:}

$1 / 2$ to $5 / 8^{\prime \prime}, 4$-sided, shiny yellow-green, persisting around 5 years.

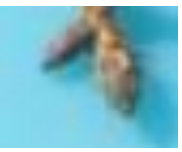

\section{Cones:}

$1 \frac{1}{4}$ unto 2 ", ovoid, chestnut brown. Scales are stiff, round in shape, and have entire margins.

\section{Twigs:}

Pubescent, orangish brown in color, peg-like projections present where needles attach.

\section{Buds:}

$1 / 3^{\prime \prime}$ long and reddish brown in color.

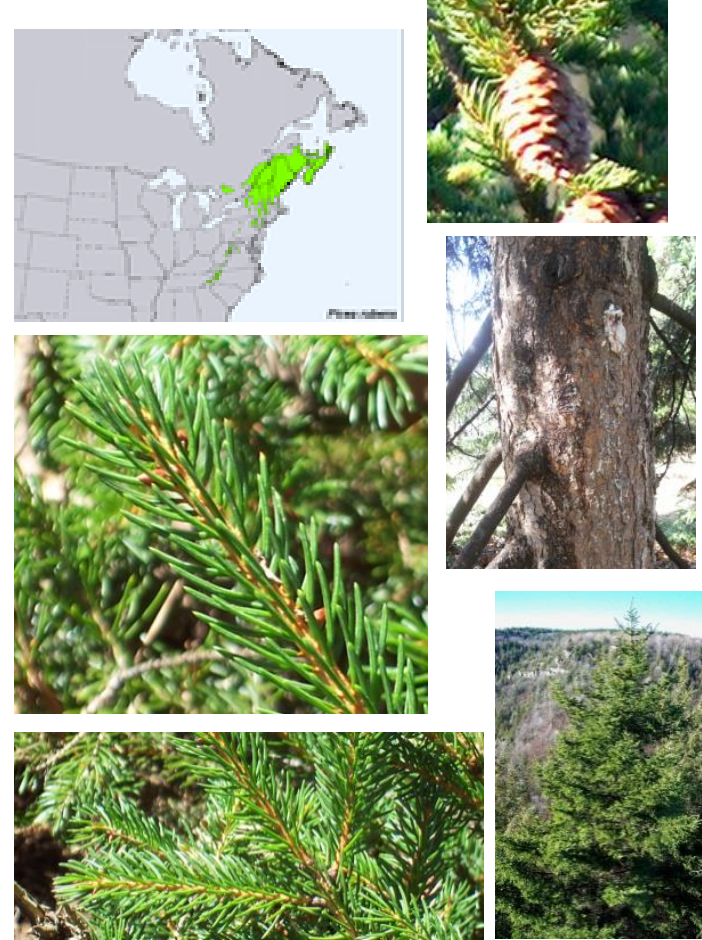

Red spruce is very tolerant of shade and has a slow growth rate. It typically grows 60 to 70 feet in height, and reaches a diameter of 1 to 2 feet. It can reach up to 120 feet in height however. It grows best in swamps and bogs to well-drained flats. It prefers acidic soils. It does not perform well in areas having hot summers. In the southern portion of its range, it occurs naturally at high elevations only. 
Black spruce

Picea mariana

Pinaceae

\section{Needles:}

$1 / 4$ to $1 / 2 ", 4$-sided, blue-green, glaucous. ${ }^{1}$

\section{Cones:}

$3 / 4$ to $1 \frac{1}{2}$ " long, ovoid, purplish to brown. Scales are round, cones may persist on the tree for many years. ${ }^{2}$

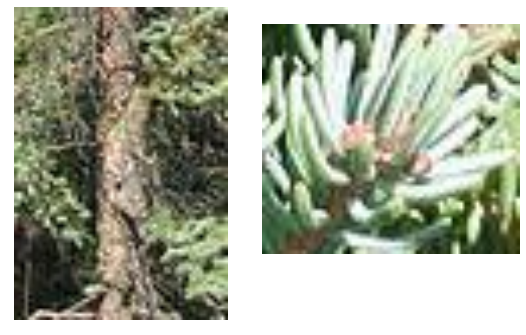

\section{Twigs:}

Pubescent, covered with peg-like projections where needles attach, yellow-brown to grey in color. ${ }^{3}$

\section{Buds:}

Short, pubescent, reddish brown in color. ${ }^{4}$
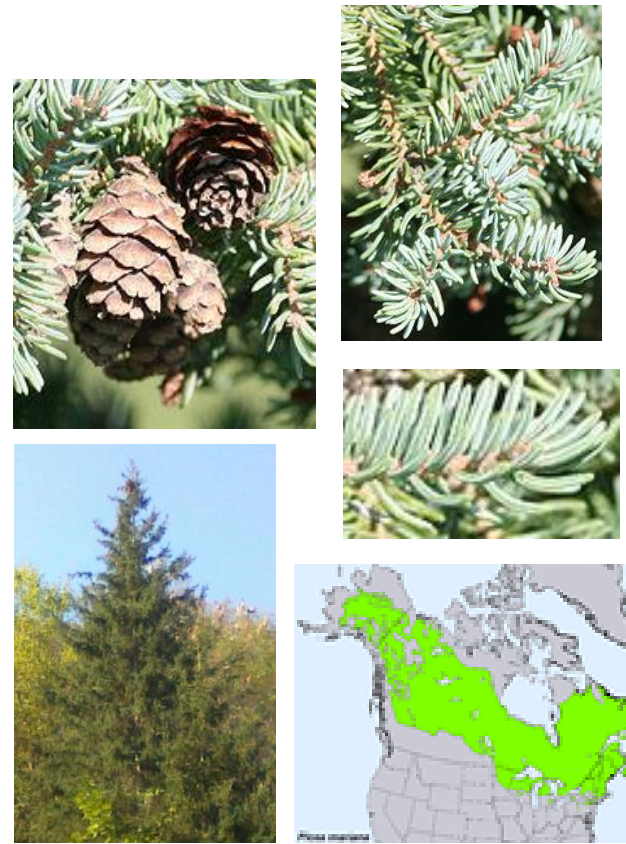

Black spruce is tolerant of shade and has a slow growth rate. It typically grows to a height of 30 to 40 feet, and attains a diameter of about a foot. Black spruce grows in areas with cold climates and does not tolerate heat well. It is often associated with permafrost. Black spruce is generally short lived.

\footnotetext{
1: Photo courtesy of http://commons.wikimedia.org/wiki/File:Picea_mariana_cones_Yukon2.jpg

2: Photo courtesy of http://commons.wikimedia.org/wiki/File:Picea_mariana_cones_Yukon2.jpg

3: Photo courtesy of http://commons.wikimedia.org/wiki/File:Picea_mariana_cones_Yukon2.jpg

4: Photo courtesy of http://commons.wikimedia.org/wiki/File:Picea_mariana_cones_Yukon2.jpg
} 
White spruce

Picea glauca

Pinaceae

\section{Needles:}

$1 / 3$ to $3 / 4 ", 4$-sided, glaucous, and green to bluish green in color. Typically they are crowded on the upperside of twigs and persist for several years.

\section{Cones:}

$1 \frac{1 / 2}{2}$ to $2 \frac{1 / 2 "}{}$ narrowly oblong, light brown.

\section{Twigs:}

Glabrous, light brown in color, slender, and may be glaucous.
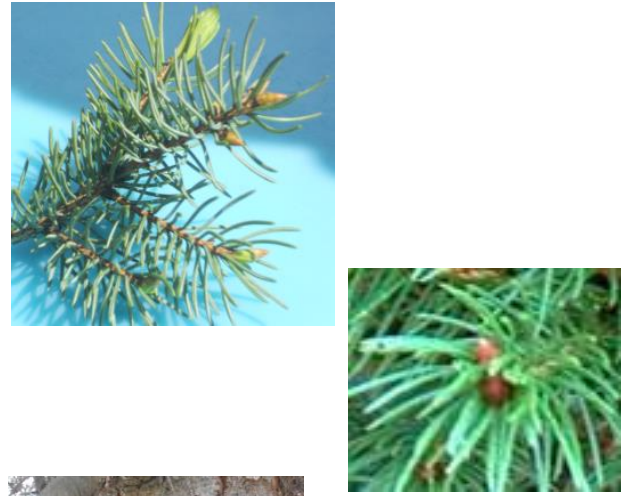

\section{Buds:}

$1 / 4$ " long, non-resinous, and chestnut brown in color.
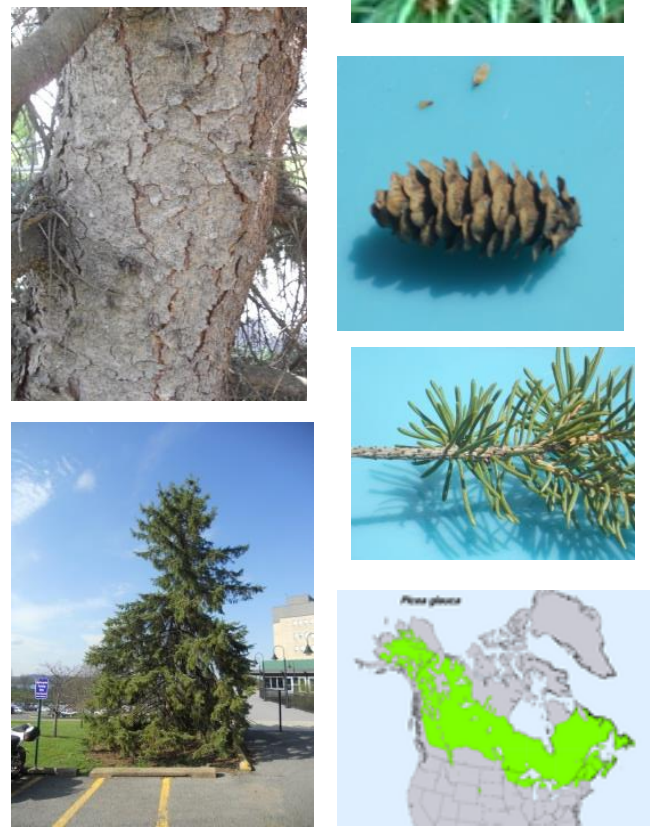

White spruce is tolerant of shade, and has a moderate growth rate. It grows to a height of 40 to 70 feet and attains a diameter of 2 feet. It generally attains a spire-like crown and is more tolerant of heat than Black spruce and Red spruce. The commonly planted Dwarf Alberta spruce is actually a cultivar of White spruce. 
Sitka spruce

Picea sitchensis

Pinaceae

\section{Needles:}

$1 / 2$ to $11 / 8^{\prime \prime}$, yellow-green above, glaucous below, very sharp, and flat. They are often almost silver colored. ${ }^{1}$
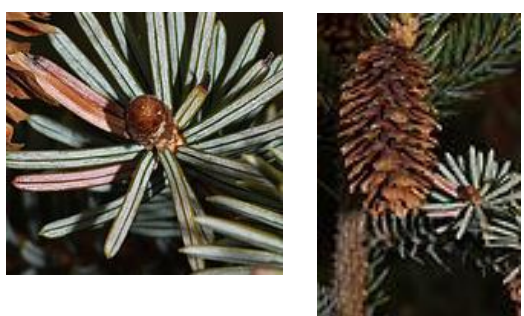

\section{Cones:}

2-4" long, ovoid-oblong, thin. ${ }^{2}$

\section{Twigs:}

Not hairy, moderately stout, light brown, peg-like projections where needles attach. ${ }^{3}$

\section{Buds:}

5/16", brownish, rounded. ${ }^{4}$
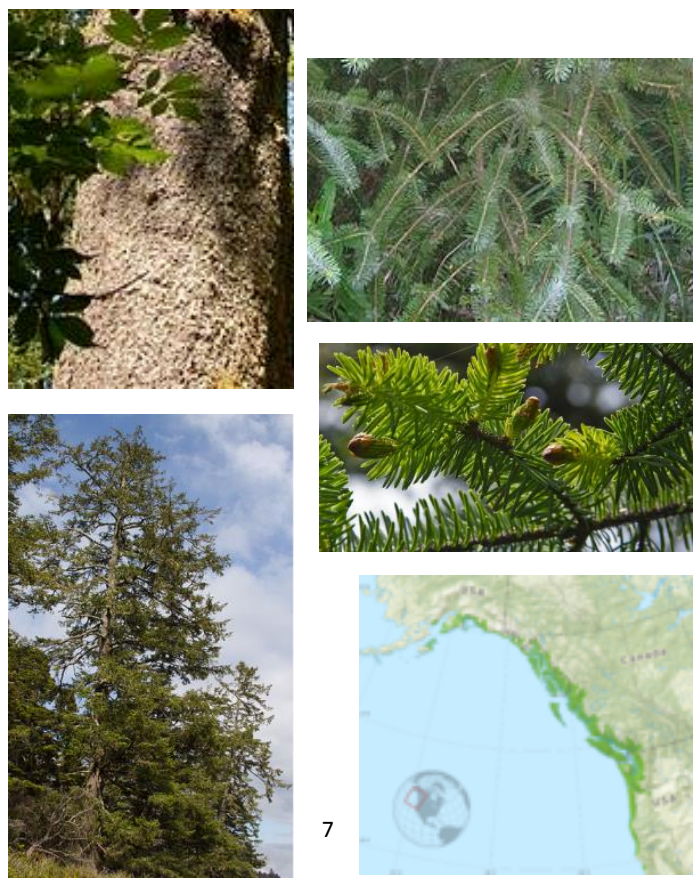

Sitka spruce is tolerant of shade and has a rapid growth rate. It grows to a heırı of 150 to 200 feet and attains a diameter of 3 to 6 feet. It is the largest of all Picea. The crown is typically composed of drooping branches. Sitka spruce grows at lower elevations. It generally has a very long life span.

1: Photo courtesy of http://commons.wikimedia.org/wiki/File:Picea_sitchensis_Wild_Pacific_Trail,_Ucluelet_4.jpg

2: Photo courtesy of http://commons.wikimedia.org/wiki/Picea_sitchensis

3: Photo courtesy of http://commons.wikimedia.org/wiki/File:Sitka_Spruce.jpg

4: Photo courtesy of http://commons.wikimedia.org/wiki/File:Picea_sitchensis_5714.JPG

5: Photo courtesy of http://commons.wikimedia.org/wiki/File:Picea_sitchensis_Tolovana_Park_Oregon.jpg

6: Image courtesy of http://commons.wikimedia.org/wiki/Picea_sitchensis 
Engelmann spruce

Picea engelmannii

Pinaceae

\section{Needles:}

1 to $11 / 8^{\prime \prime}$, blue-green, rank odor, 4-sided, and prickly. ${ }^{1}$

\section{Cones:}

1 to $2 \frac{1}{2}$ " long, ovoid-oblong, thin scales, wedgeshaped, and light brown to red-brown in color. ${ }^{2}$

\section{Twigs:}

Pubescent, moderately stout, yellowish brown. ${ }^{3}$

\section{Buds:}

$3 / 16^{\prime \prime}$, rounded, brownish in color. ${ }^{4}$
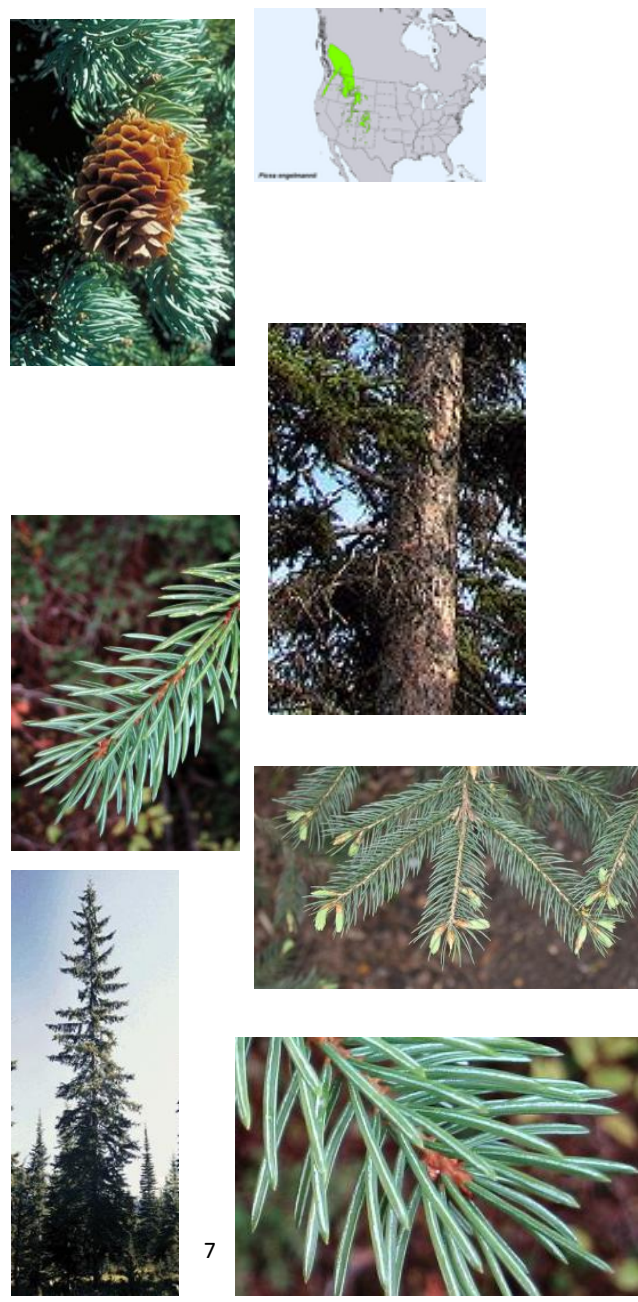

Engelmann spruce is tolerant of shade and has a rapid growth rate. It i edches a height of 100 to 125 feet and a diameter of 1 to 3 feet. It grows best on moist, deep soils. Engelmann spruce is an important timber tree.

1: Photo courtesy of http://commons.wikimedia.org/wiki/File:EngelmannSpruce_7777.jpg

2: Photo courtesy of http://commons.wikimedia.org/wiki/File:Picea_engelmannii_UGA2.jpg

3: Photo courtesy of http://commons.wikimedia.org/wiki/File:Picea_engelmannii_foliage.JPG

4: Photo courtesy of http://commons.wikimedia.org/wiki/File:EngelmannSpruce_7777.jpg

5: Photo courtesy of http://commons.wikimedia.org/wiki/File:Picea_engelmannii_HyasLake.jpg 
Colorado blue spruce

Picea pungens

Pinaceae

\section{Needles:}

Dull green to blue-green; glaucous; sharp, pungent smell. Needles prevalent on both upper and lower surfaces of twigs.
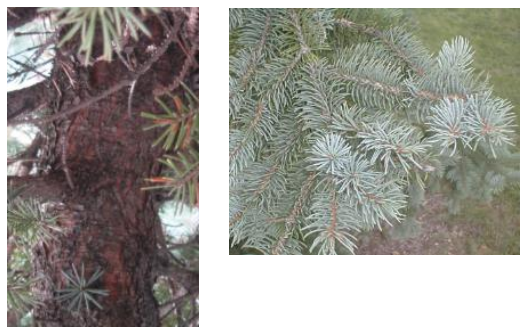

\section{Cones:}

3" long, slender cylindrical. Brown in color with violet bloom.

\section{Twigs:}

Glabrous, stout, yellowish to orange in color.

\section{Buds:}

Yellow to orangish brown, scales reflexed at apex, non-resinous.
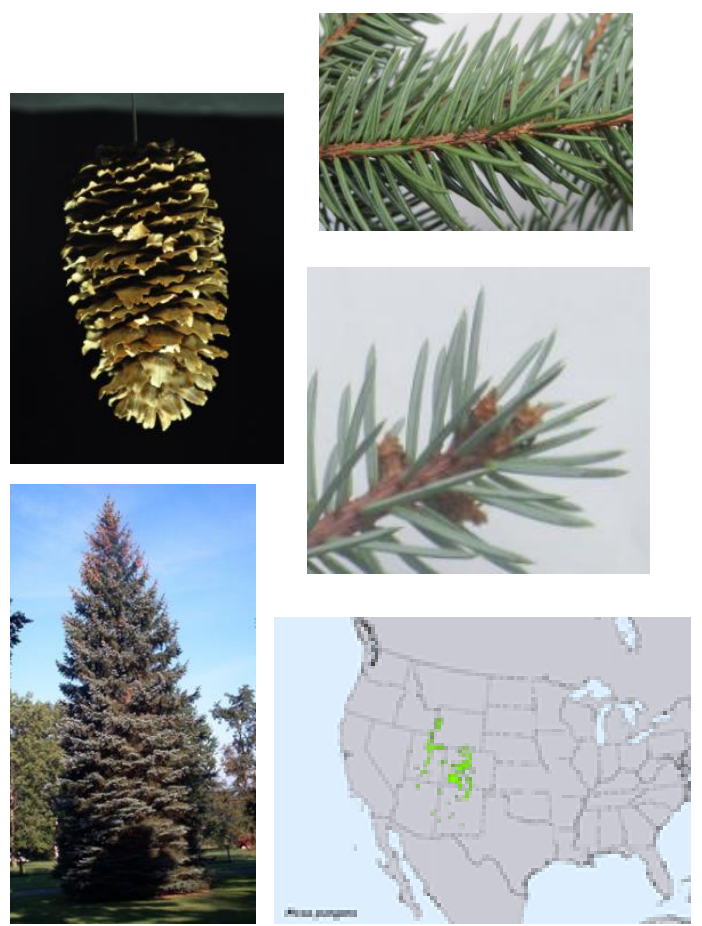

Colorado spruce is tolerant of shade and has a moderate growth rate. It grows to a height of 80 to 100 feet, and reaches a diameter of 1 to 2 feet. Colorado spruce is quite susceptible to Cytospora canker which often kills off the lower branches. Considering the many alternatives, and its susceptibility to disease, it is much over planted in the eastern United States. 
Balsam fir

Abies balsamea

Pinaceae

\section{Needles:}

Flattened needles, $3 / 4$ " long, shiny dark green above and silvery-blue below. A grove is present on the upper surface. Citrus like odor present when crushed.

\section{Cones:}

Resinous, upright, 2 to $31 / 2$ inches long, oblong to cylindrical, green with purple tinge, with bracts shorter than the scales. Scales fall off at maturity. ${ }^{1}$

\section{Twigs:}

Smooth, slender, and grey in color.

\section{Buds:}

$1 / 8^{\prime \prime}$ to $1 / 4 "$, reddish-brown and resin covered. ${ }^{2}$
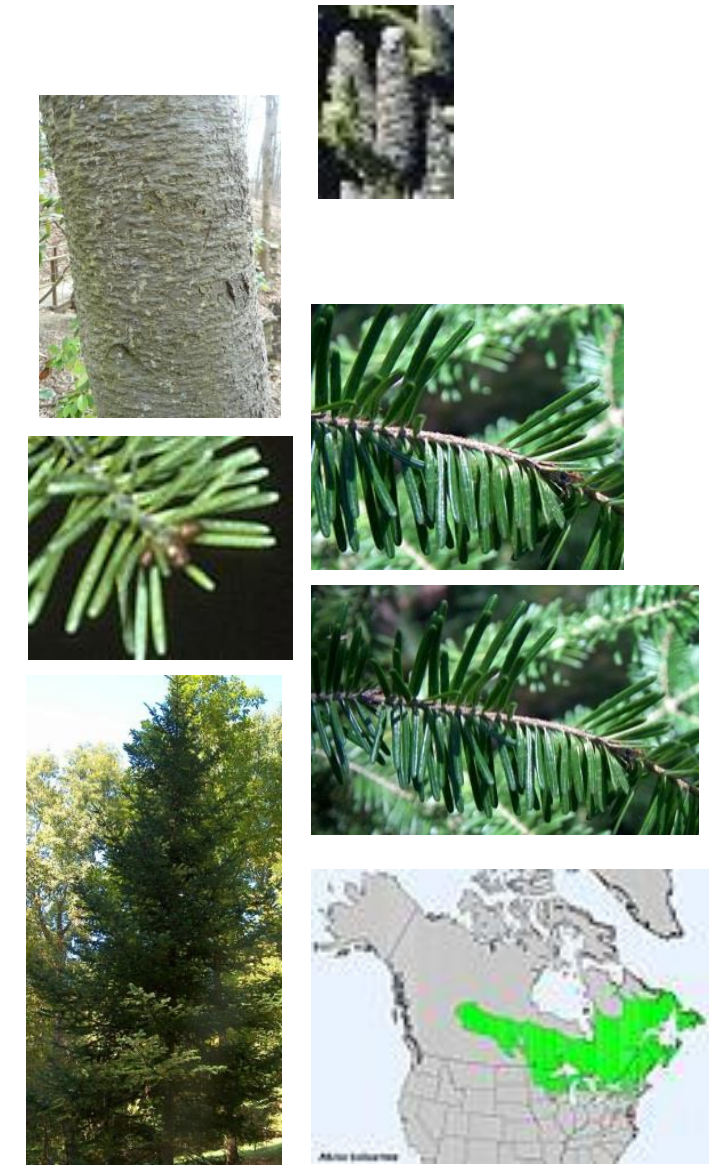

Balsam fir is tolerant of shade and has a rapid growth rate. It grows to a height of 40 to 60 feet and reaches a diameter of 1 to 1.5 feet. It grows best on moist sites. Unlike Picea, twigs lack peg-like projections where needles attach. Bark may become broken into scaly plates on older trees. Balsam fir does not tolerate heat well and thus is limited to higher elevations in the southern portion of its range. 
Red fir, Silvertip fir

Abies magnifica

Pinaceae

\section{Needles:}

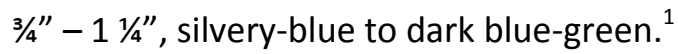

\section{Cones:}

6" to 9", upright, purplish brown, bracts shorter than the scales. Scales fall at maturity. ${ }^{2}$

\section{Twigs:}

Light brown in color. Peg-like projections absent. ${ }^{3}$

\section{Buds:}

Small, oval, dark brown in color.

\section{Bark:}

Smooth, chalky on young stems; thick and deeply furrowed, reddish brown on old trees. ${ }^{4}$
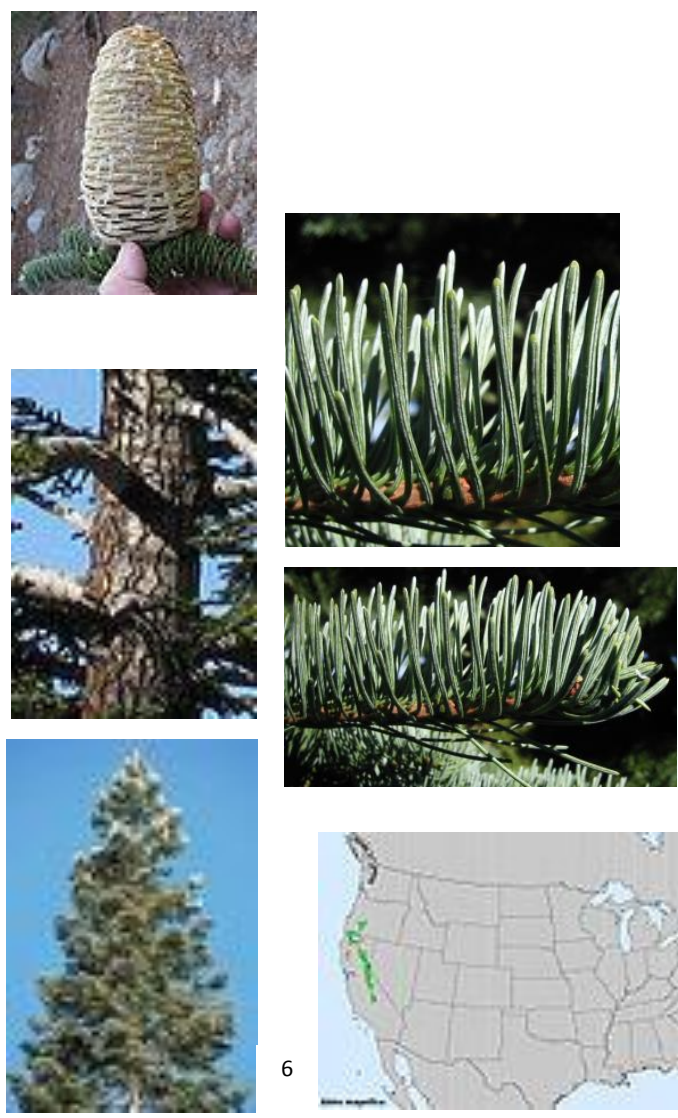

6

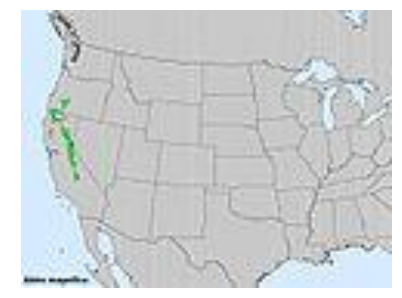

Red fir is moderately shade-tolerant and has a slow growth rate. It grows to a height of 100 to 150 feet and attains a diameter of 2 to 4 feet. It grows best on moist, but well-drained sites. The variety, Shasta red fir has cones with scales which are longer than the scales. It typically has a spire like crown.

1: Photo courtesy of http://commons.wikimedia.org/wiki/File:Abies_magnifica_8009.jpg

2: Photo courtesy of http://commons.wikimedia.org/wiki/Abies_magnifica

3: Photo courtesy of http://commons.wikimedia.org/wiki/File:Abies_magnifica_8009.jpg 


\section{Grand fir}

Abies grandis

Pinaceae

\section{Needles:}

$1 / 2 "$ to $2 "$, yellow-green above, silvery below, 2-ranked, flat, notched at the end. ${ }^{1}$

\section{Cones:}

$2 \frac{1 / 2}{2}$ to $4 \frac{1}{4}{ }^{\prime \prime}$, upright; yellowish green to greenish purple, bracts shorter than scales. Scales fall at maturity. $^{2}$

\section{Twigs:}

Slender, brown. Peg-like projections absent. ${ }^{3}$

\section{Buds:}

Rounded, resinous, purple to brown in color. ${ }^{4}$
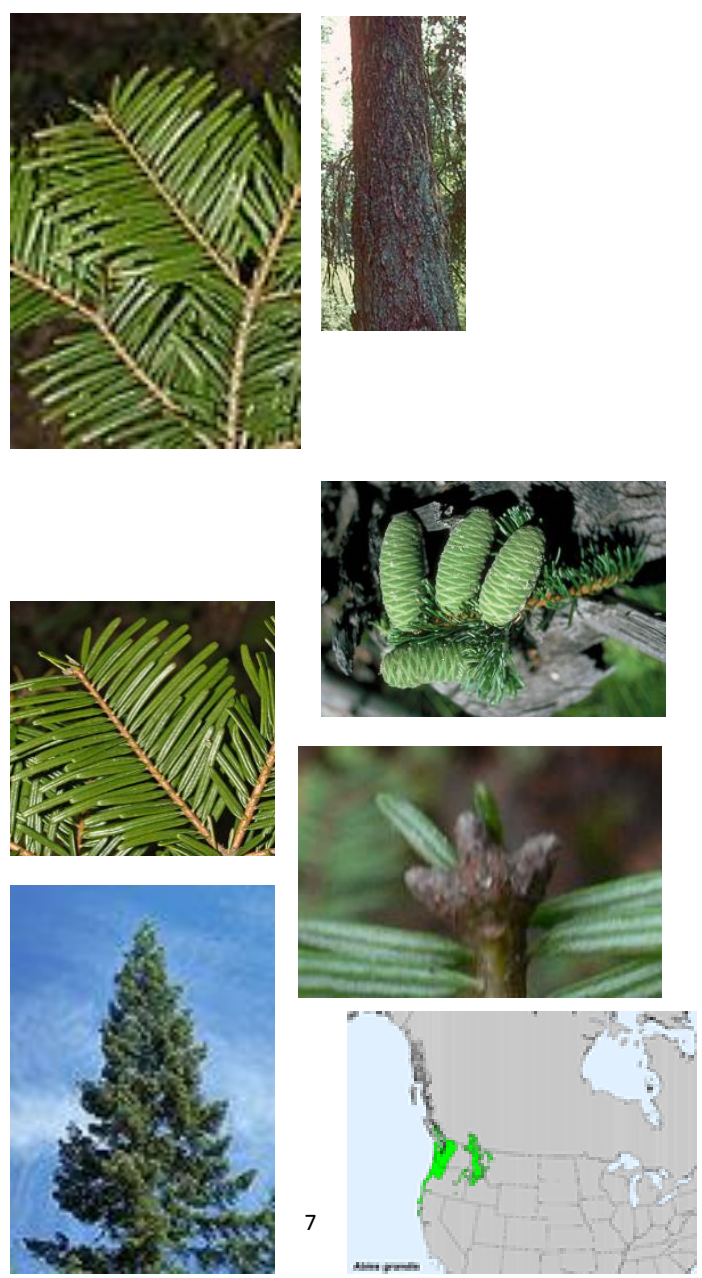

Grand fir is tolerant of shade and has a rapid growth rate. It grows to 125 to 150 feet in height and reaches a diameter of 2 to 4 feet. The crown of older trees is typically rounded in shape.

1: Photo courtesy of http://commons.wikimedia.org/wiki/File:Abies_grandis_5359.JPG

2: Photo courtesy of http://commons.wikimedia.org/wiki/File:Abies_grandis_cones.jpg

3: Photo courtesy of http://commons.wikimedia.org/wiki/Abies_grandis 
Noble fir

Abies procera

Pinaceae

\section{Needles:}

1 " to $1 \frac{1}{2}$ "; blue-green, 4-angled on upper branches and flat on lower branches. ${ }^{1}$

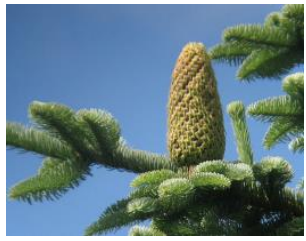

\section{Cones:}

$4 "$ to $6^{\prime \prime}$, upright; $13 / 4^{\prime \prime}$ to $2 \frac{1 / 4}{\prime \prime}$ diameters; olive-brown to purple. Bracts are long. ${ }^{2}$

\section{Twigs:}

Slender, reddish brown, finely pubescent. ${ }^{3}$

\section{Buds:}

Rounded in shape, with long scales surrounding the base; resinous. ${ }^{4}$
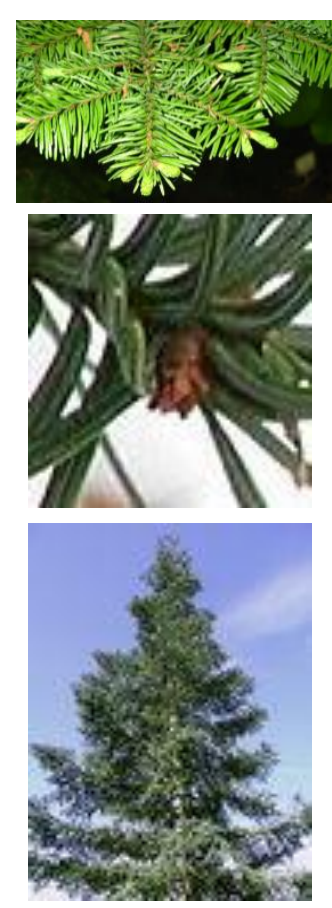
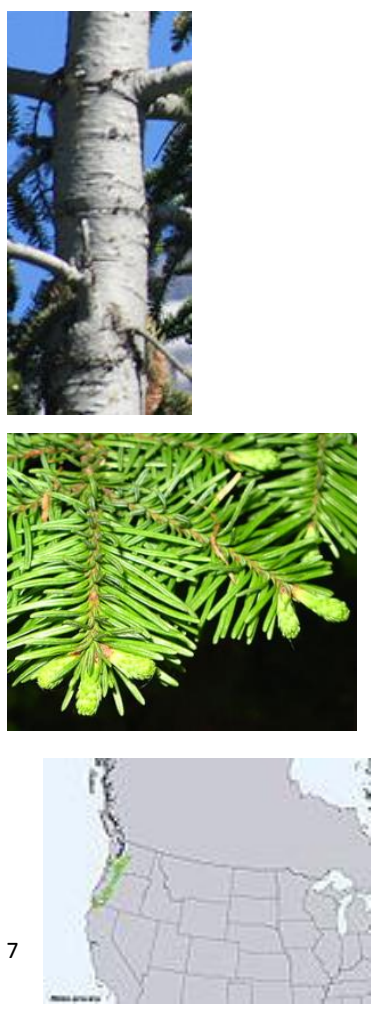

Noble fir is tolerant of shade and has a moderately rapid growth rate. It grows to a height of 100 to 150 feet and attains a diameter of 3 to 5 feet. The twigs lack peg-like projections. It grows best on moist sites with a deep soil. Noble fir typically develops a dome-like crown.

1: Photo courtesy of http://commons.wikimedia.org/wiki/File:Abies_procera_foliage_PAN_1.jpg

2: Photo courtesy of http://commons.wikimedia.org/wiki/File:Abies_procera_cone.jpg

3: Photo courtesy of http://commons.wikimedia.org/wiki/File:Abies_procera_foliage_PAN_1.jpg

4: Photo courtesy of http://commons.wikimedia.org/wiki/File:Abies-procera-needles.JPG

5: Photo courtesy of http://commons.wikimedia.org/wiki/File:Abies_procera_foliage_Rainier.jpg 
White fir

Abies concolor

Pinaceae

\section{Needles:}

2 " to 3 "; silvery-blue to silvery-green, extend at right angles from all sides of stem, flat.

\section{Cones:}

3" to 5", upright; oblong; olive green to purple. Bracts are shorter than the scales.
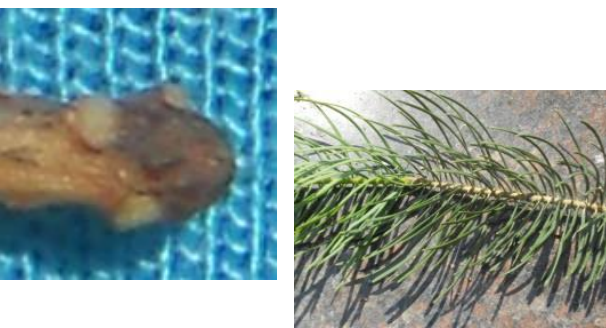

\section{Twigs:}

Moderately stout, grey in color.

\section{Buds:}

Brown in color, large, and covered in resin.
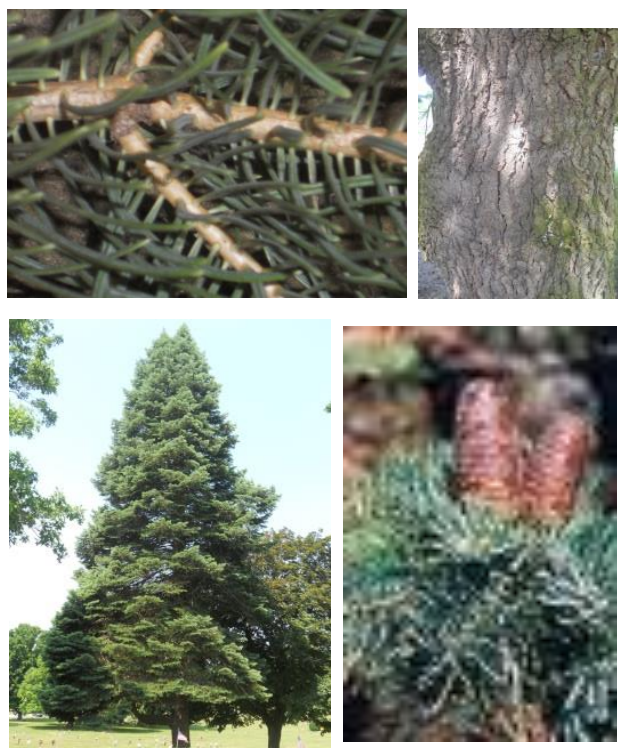

White fir is tolerant of shade, and has a slow growth rate. It generally grows to a height of 125 to 150 feet and attains a diameter of 2 to 4 feet. It typically develops a dome shaped crown. White fir will tolerate drier soils than other firs. It is used as an ornamental and is sometimes seen in landscape plantings in the eastern U.S. It is also grown for Christmas trees. 
Subalpine fir

Abies lasiocarpa

Pinaceae

\section{Needles:}

1 " to $13 / 4$ "; pale blue-green, strongly aromatic, somewhat grooved above. ${ }^{1}$

\section{Cones:}

$2 \frac{1}{4} 4^{\prime \prime}$ to $4 "$, cylindrical, purplish-gray to black; immature cones upright. Bracts are shorter than scales. ${ }^{2}$

\section{Twigs:}

Smooth, stout, greyish brown in color. ${ }^{3}$
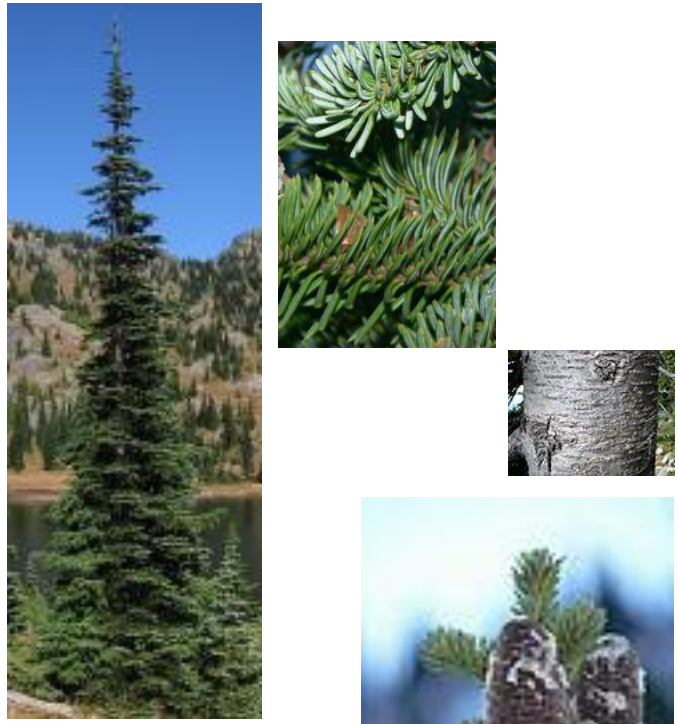

Buds:

Small, resinous, rounded, brown

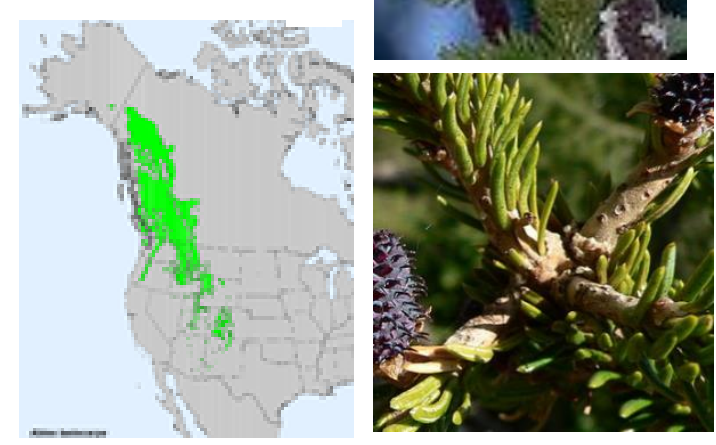

Subalpine fir is tolerant of shade and has a slow growth rate. It reaches 40 to 100 feet in height and grows to 1 to 2 feet in diameter. Subalpine fir develops a characteristic spire-like crown. Subalpine firs is not well adapted to heat. It is however, quite tolerant of cold and grows at high altitudes to the timberline. 
Douglas-fir

Pseudotsuga menziesii

Pinaceae

\section{Needles:}

$3 / 4$ " to $1 \frac{1 / 4}{4}$; yellow-green, flattened, extending from all sides of twig, a shiny green color.

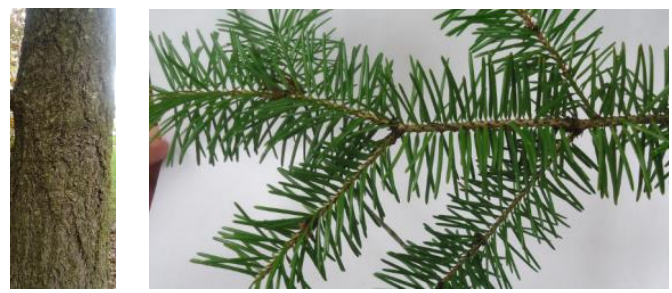

\section{Cones:}

3" to 4"; pendent, ovoid-cylindrical, three-pronged bracts are longer than the scales.

\section{Twigs:}

New twigs pubescent. Older twigs almost glabrous and greyish brown in color.

\section{Buds:}

$1 / 4$ " to $1 / 3^{\prime \prime}$ long, pointed at the ends, brown in color, and resinous at the base.
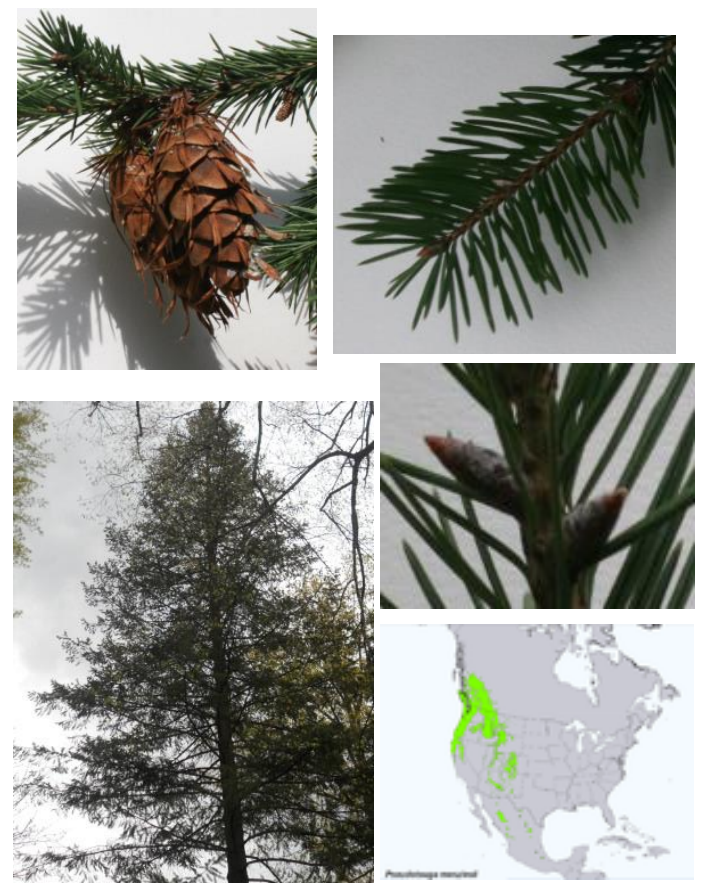

Douglas-fir is intermediate in shade-tolerance and has a rapid growth rate. It can grow up to 250 feet in height on good sites and can attain a diameter of 2 to 3 feet. It is the largest sized tree in the Pacific Northwest and is an important timber tree. It is also commonly grown for Christmas trees. Douglas-firs which grow in the inland regions, are sometimes considered as a separate species from those which grow along the Pacific Coast. Douglas-fir is sometimes planted in the eastern U.S. as an ornamental. 
Eastern hemlock

Tsuga canadensis

Pinaceae

\section{Needles:}

$1 / 3^{\prime \prime}$ to $2 / 3^{\prime \prime}$, dark green in color, flattened, with 2 white lines of stomata on the undersides. Needles have a short stem present.

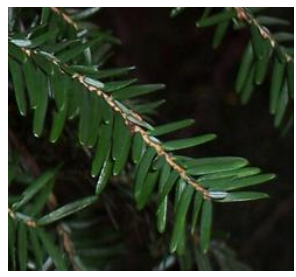

\section{Cones:}

$1 / 2$ " to $3 / 4 "$, oblong-ovoid, pendant, brown in color, with a short stem.

\section{Twigs:}

Greyish brown in color and slender; hairy when young.

\section{Buds:}

Very small, light brown in color, hairy.
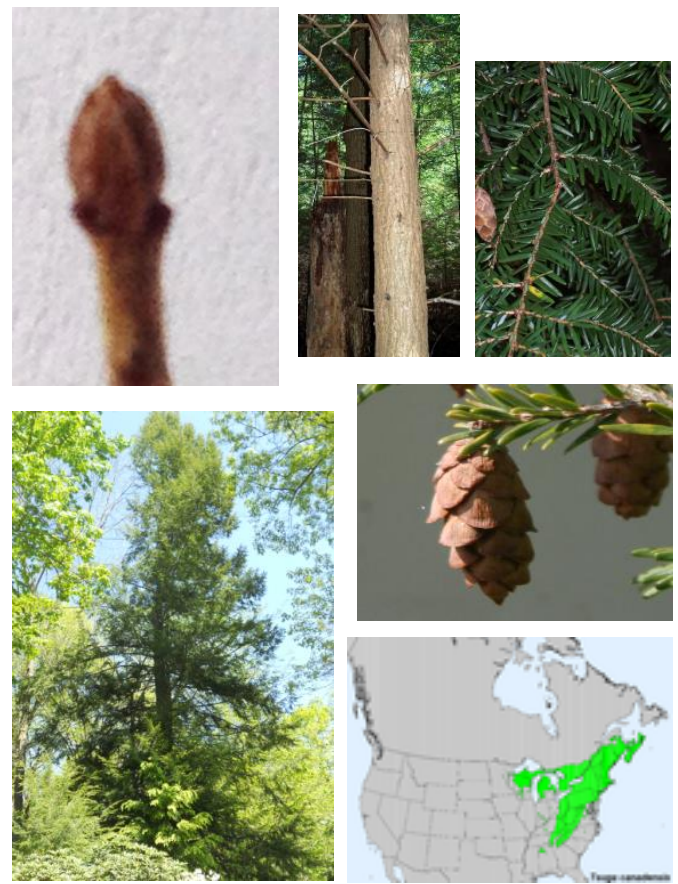

Eastern hemlock is very tolerant of shade and has a slow growth rate. It generally grows to a height of 60 to 90 feet, and attains a diameter of 1 to 3 feet. The crown is often dense. Eastern hemlock can be identified by its drooping terminal leader. Often planted as an ornamental and can be trimmed into a hedge. Currently, it is threatened by the Hemlock woolly adelgid, a small insect that sucks sap from the twigs, needles, etc. Eastern hemlock prefers moist, cool sites, but will tolerate fairly warm, dry sites as well. 
Western hemlock

Tsuga heterophylla

Pinaceae

\section{Needles:}

$1 / 4$ to $3 / 4^{\prime \prime}$, flattened, shiny green, 2 poorly defined rows of stomata on the undersides. ${ }^{1}$

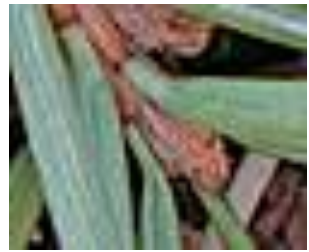

\section{Cones:}

$3 / 4$ to $1 "$, ovoid, light brown in color, no stem present. $^{2}$

\section{Twigs:}

Reddish brown in color, and pubescent for up to 6 years. $^{3}$
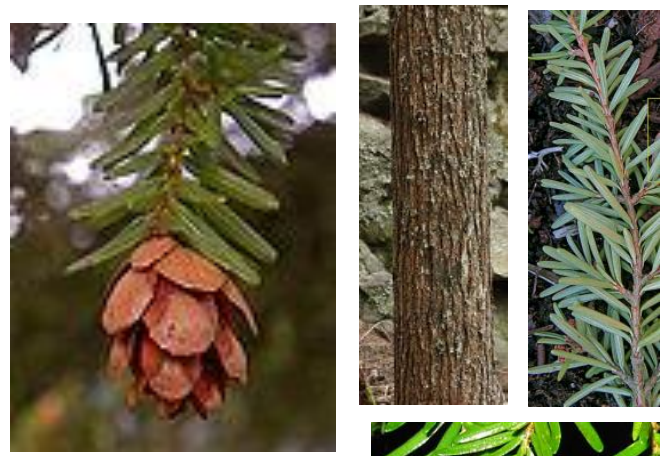

\section{Buds:}

Very small, oval, greyish brown. ${ }^{4}$
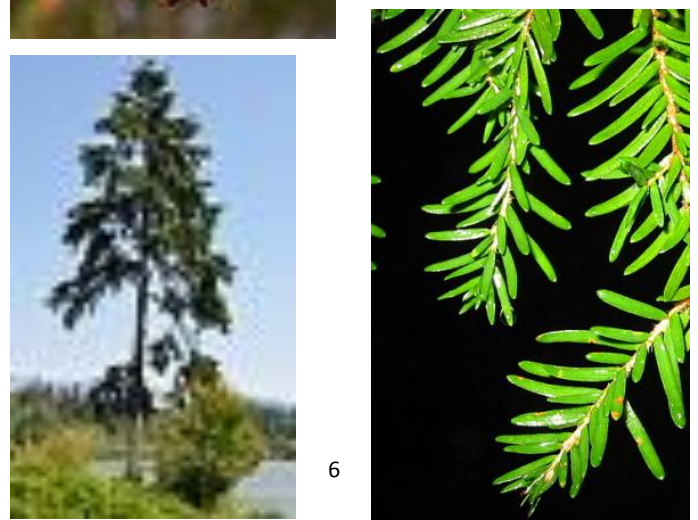

Western hemlock is tolerant of shade and has a rapid growth rate. It grows to a neight of 125 to 175 feet and reaches 2 to 5 feet in diameter. It is readily distinguished by its pendulous branchlet tips. Timber of Western hemlock is sold as hem/fir.

1: Photo courtesy of http://commons.wikimedia.org/wiki/File:WesternHemlock_7522.jpg

2: Photo courtesy of http://commons.wikimedia.org/wiki/Tsuga_heterophylla

3: Photo courtesy of http://commons.wikimedia.org/wiki/File:Tsuga_heterophylla_foliage_cones_Change_Creek.jpg

4: Photo courtesy of http://commons.wikimedia.org/wiki/File:Tsuga_heterophylla_foliage_cones_Change_Creek.jpg 
Redwood

Sequoia sempervirens

Taxodiaceae

\section{Needles:}

$1 / 2$ " to 1 " long, flat, spirally arranged, dark yellowgreen, two whitish bands below; bases of needles extend down the twigs from where they are attached ${ }^{1}$

\section{Cones:}

$3 / 4 "$ to $1 "$, ovoid, reddish brown, with 15 to 20 peltate scales. ${ }^{2}$
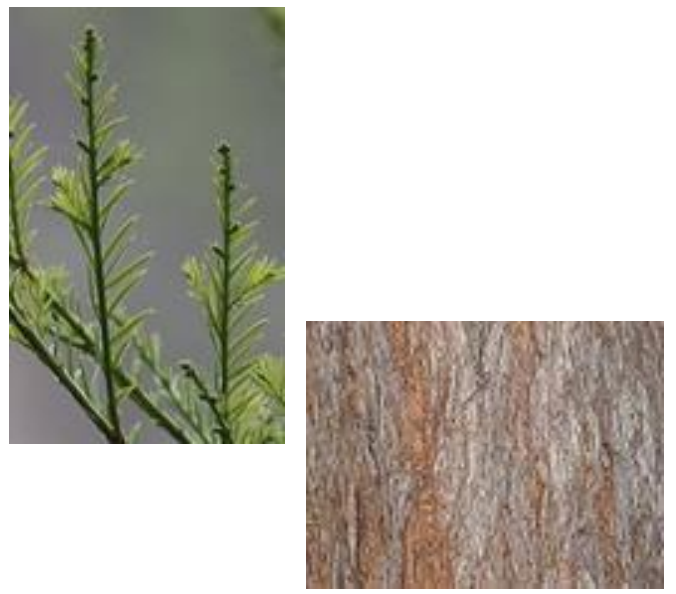

\section{Twigs:}

Slender, green. ${ }^{3}$

\section{Buds:}

Very small and scaly. ${ }^{4}$
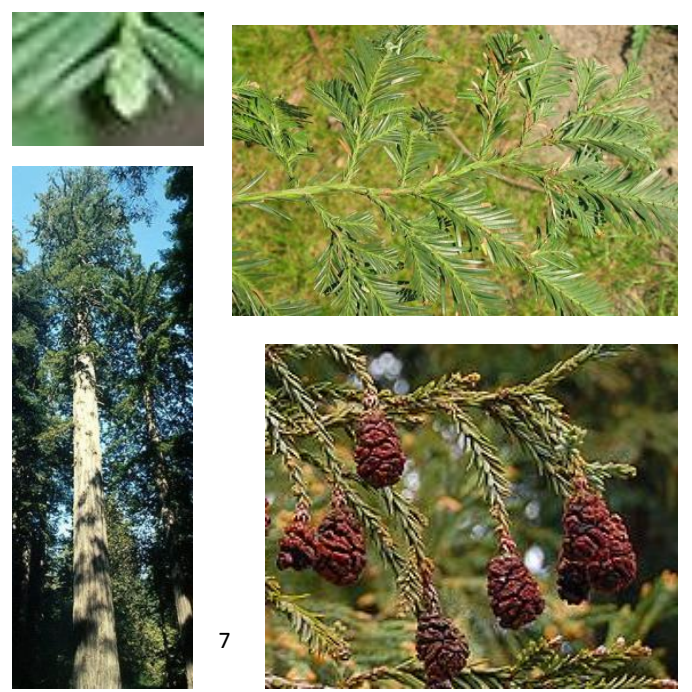

Redwood is quite tolerant of shade and has a very rapid growth rate. It gruws 200 to 275 feet tall, and attains a diameter of 8 to 10 feet. Some Redwoods have grown taller than 350 feet. They are currently the world's tallest trees. The leaves are long and flat on young trees and shaded shoots, and scale-like on shoots in full sun. Redwood has the ability to sprout from stumps, which is rare in conifers. Redwood is native to an area referred to as the fog belt, where they are a valuable asset for tourism.

1: Photo courtesy of http://commons.wikimedia.org/wiki/File:Sequoia_sempervirens_foliage_Mendocino.jpg

2: Photo courtesy of http://commons.wikimedia.org/wiki/File:Sequoia_sempervirens_foliage_cones_Mount_Tamalpais_1.jpg

3: Photo courtesy of http://commons.wikimedia.org/wiki/File:Sequoia_sempervirens_needles_by_Line1.jpg

4: Photo courtesy of http://commons.wikimedia.org/wiki/File:Sequoia_sempervirens1.jpg

5: Photo courtesy of http://commons.wikimedia.org/wiki/Sequoia_sempervirens

6: Image courtesy of http://commons.wikimedia.org/wiki/Sequoia_sempervirens

7: Photo courtesy of http://commons.wikimedia.org/wiki/File:Coastal_redwood.jpg 
Giant sequoia

\section{Sequoiadendron giganteum}

Taxodiaceae

\section{Needles:}

$1 / 2$ " on leaders; $1 / 4$ " on lower branches, bluish green in color, awl-like in shape, but lance-shaped at the ends of branches. ${ }^{1}$

\section{Cones:}

$2 "-31 / 2$; ; ovoid with peltate scales, and persist for several years. ${ }^{2}$

\section{Twigs:}

Slender, green in color. ${ }^{3}$

\section{Buds:}

Very small, scaly. ${ }^{4}$
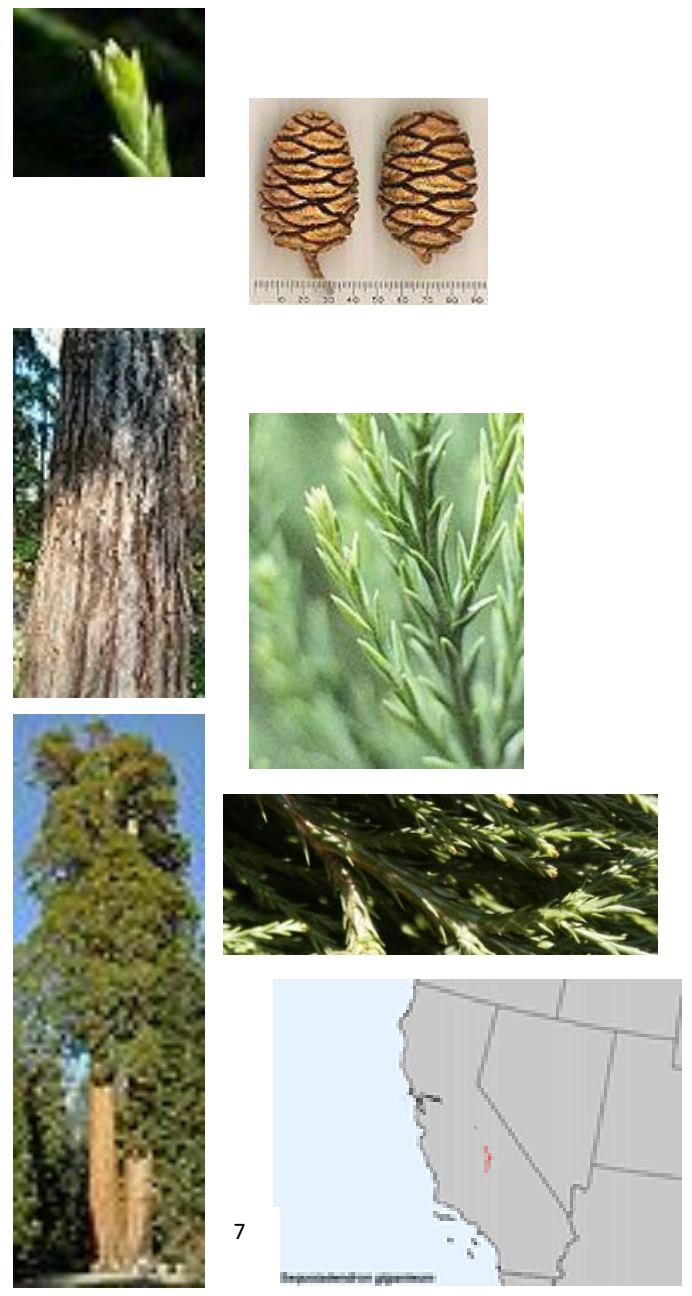

Giant sequoia is very tolerant of shade and has a very rapid growth rate. It reaches a height of 250 to 300 feet and a diameter of 10 to 15 feet. Giant sequoia is the world's largest tree in terms of diameter. The General Sherman Tree is 272 feet in height and has an average basal diameter of 30.7 feet. It grows naturally in a few groves in the Sierra Nevada. The cones have between 24 and 40 scales. Giant sequoia is an important source of Tourism and may live longer than 4,000 years. 


\section{Baldcypress}

\section{Taxodium distichum}

Taxodiaceae

\section{Needles:}

Deciduous; $1 / 2$ " to $3 / 4^{\prime \prime}$; two-ranked; yellow-green in summer, turning copper colored in the fall.

\section{Cones:}

$3 / 4 "$ to $1 "$; subglobose, rugose, with a wrinkled surface.
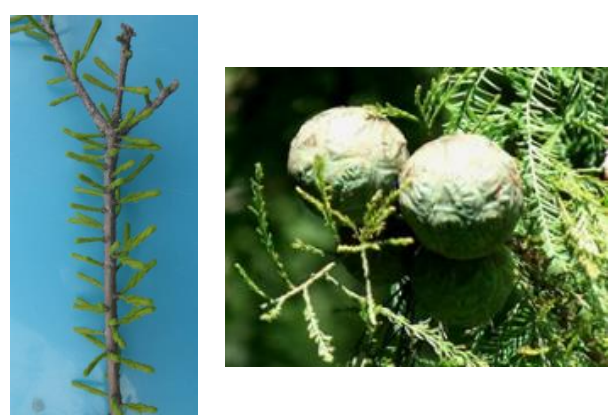

\section{Twigs:}

Reddish brown in color, and slender.
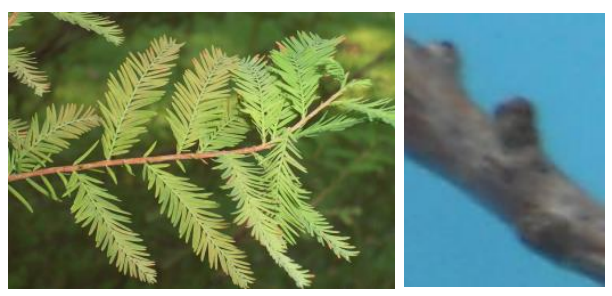

\section{Buds:}

$1 / 16^{\prime \prime}$ to $1 / 8^{\prime \prime}$ in length, greyish brown in color, and rounded in shape.
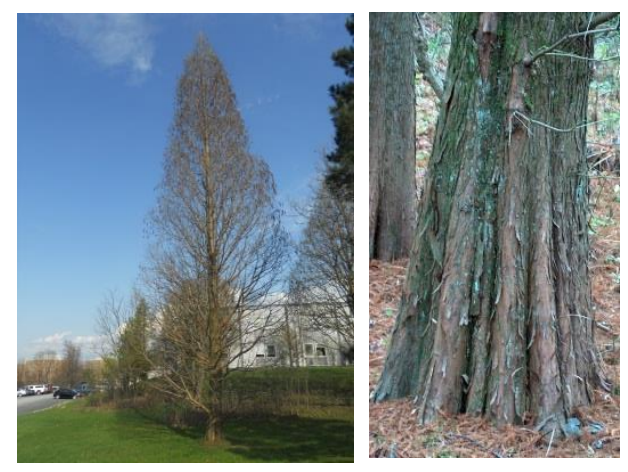

Baldcypress is intermediate in shade-tolerance and has a slow growth rate. It reaches a height of 100 to 125 feet and attains a diameter of 3 to 5 feet. It generally grows in swamps and near water. When growing near water, it will develop woody "knees". Cones mature in one growing season. Although often associated with the southeastern U.S., Baldcypress is often planted and grows quite well in locations much further north than its native range. 
Northern whitecedar

Thuja occidentalis

Cupressaceae

\section{Needles:}

1/4" long, yellow-green, scalelike, flattened; glandular beneath.

\section{Cones:}

$1 / 3^{\prime \prime}$ to $1 / 2$ " long, erect, oblong, Brown in color, with 8 to 10 woody scales.

\section{Twigs:}

Reddish brown in color, green when young, flattened into fan-like sprays, slender.

\section{Buds:}

Very, very small, yellowish, scaly.
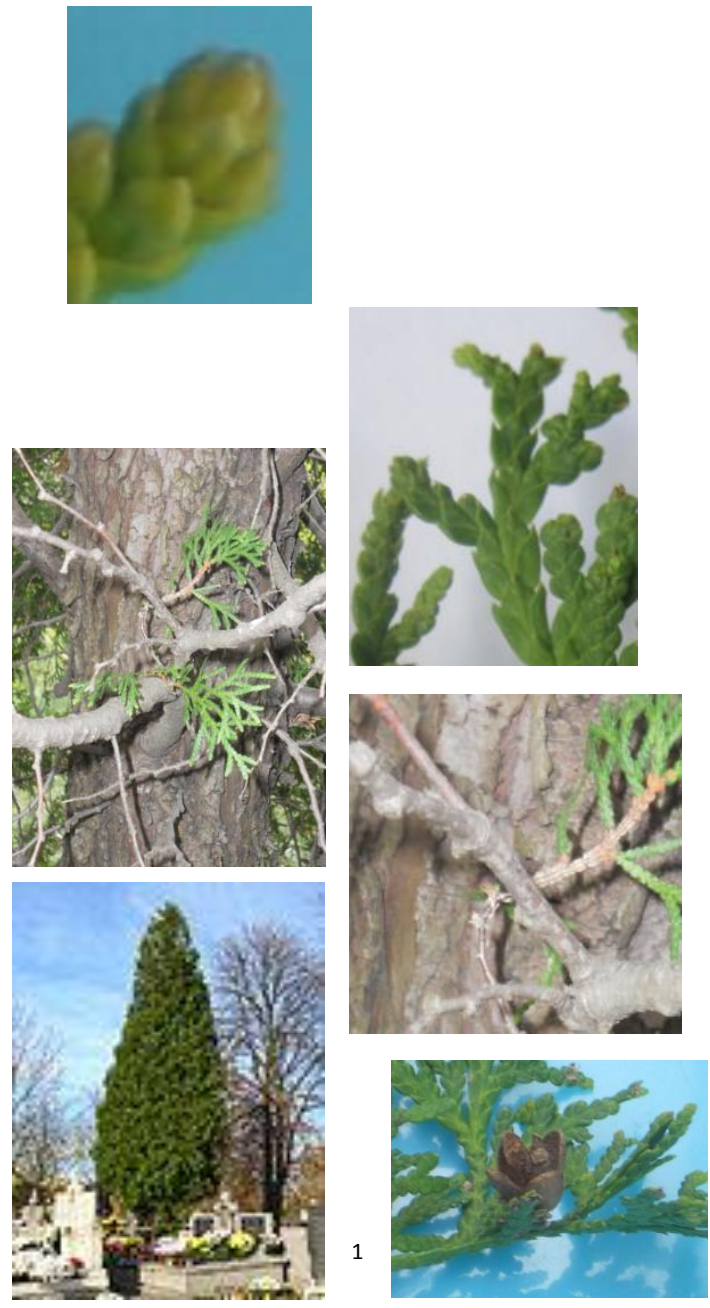

Northern whitecedar is intermediate in shade-tolerance and has a slow growth । rate. It generally grows to a height of 40 to 50 feet and reaches a diameter of 2 to 3 feet. It prefers to grow on limestone soils. The wood of Northern whitecedar is quite resistant to decay. Northern whitecedar is used heavily as an ornamental and many cultivars exist which often appear in landscapes. Many people are more familiar with how this species appears in landscapes, than how it does in its native forest habitat. 
Western redcedar

Thuja plicata

Cupressaceae

\section{Needles:}

$1 / 8^{\prime \prime}$ to $1 / 4$ " long, dark yellow-green, and scalelike. small branches are flattened and have a fernlike

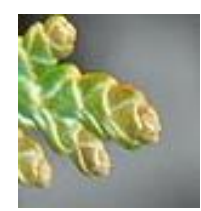
appearance.

\section{Cones:}

$1 / 3^{\prime \prime}$ to $1 / 2$ ", erect, oblong, brown in color, with 8 to 10 scales. ${ }^{1}$

\section{Twigs:}

Small branches are flattened and have a fernlike appearance; twigs are reddish brown to grey, slender.

\section{Buds:}

Very small, scaly, yellowish in color. ${ }^{2}$
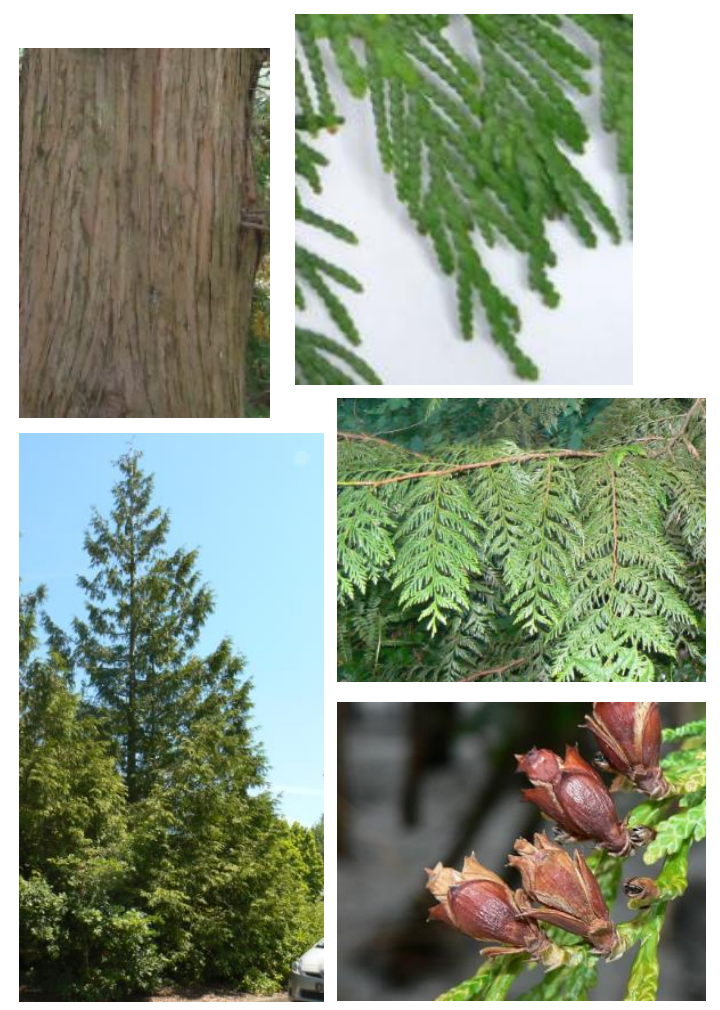

Western redcedar is very tolerant of shade and has a slow growth rate. It grows to a height of 150 to 200 feet and reaches a diameter of 3 to 8 feet. It is used as an ornamental and for timber. Its wood is resistant to decay and is quite durable. Many cultivars of this species exist. Western redcedar grows best on moist sites.

1: Photo courtesy of http://commons.wikimedia.org/wiki/File:Thuja_plicata_43569.JPG

2: Photo courtesy of http://commons.wikimedia.org/wiki/File:Thuja_plicata_43570.JPG 
Incense-cedar

Calocedrus decurrens

\section{Cupressaceae}

\section{Needles:}

$1 / 8^{\prime \prime}$ to $1 / 2$ "; dark yellow-green, scalelike, glandular, in whorls of 4 , aromatic.

\section{Cones:}

$3 / 4$ to $1 \frac{1}{2}{ }^{\prime \prime}$, pendent, leathery, duck bill like in shape, brown in color, with 6 scales. ${ }^{1}$

\section{Twigs:}

Branchlets appear in flat, vertical sprays.

\section{Buds:}

Very small, scaly.
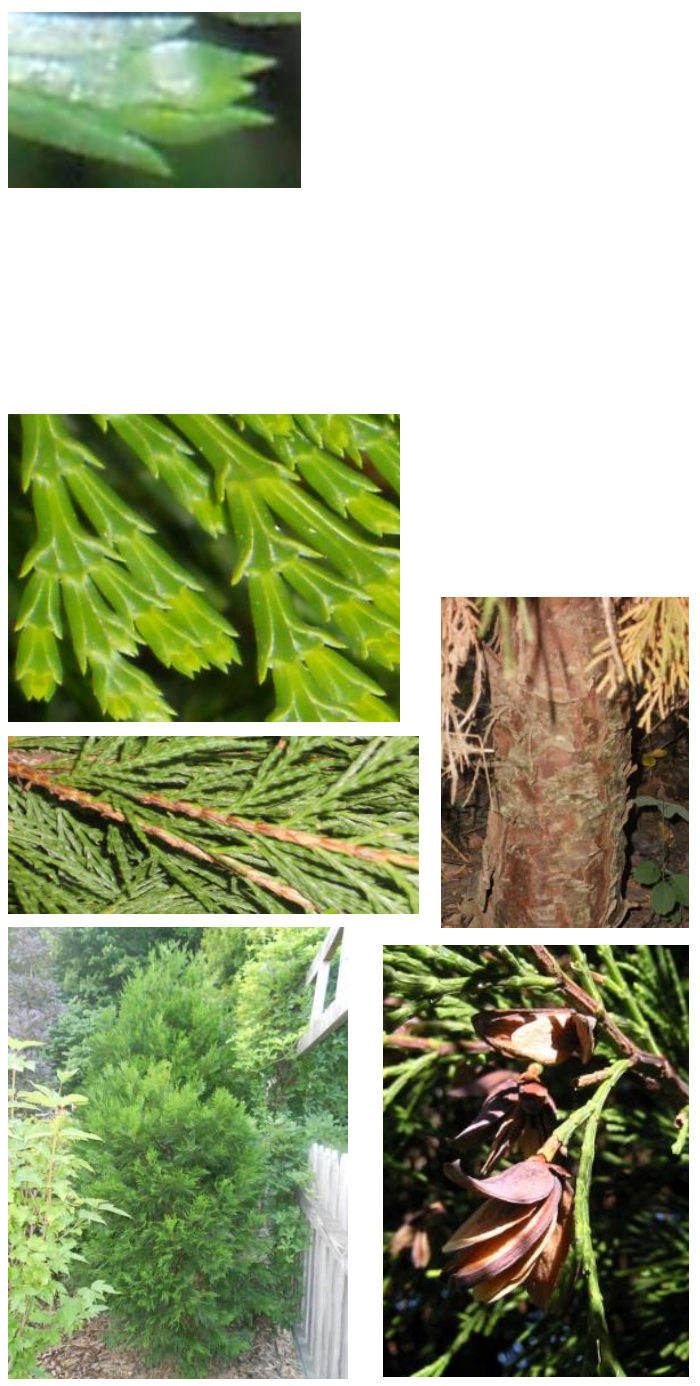

Incense-cedar is tolerant of shade and has a slow growth rate. It reaches a height of 100 to 150 feet and attains a diameter of 3 to 4 feet. Crown is cone shaped when young, but becomes more rounded with age. Incense-cedar is an important source of pencil stock. It prefers to grow on moist, somewhat sheltered sites. 
Alaska cedar, Yellow cedar

\title{
Chamaecyparis nootkatensis
}

\author{
Cupressaceae
}

\section{Needles:}

Scale-like; $1 / 16^{\prime \prime}$ to $1 / 8^{\prime \prime}$ long, closely appressed to the twigs, yellow-green in color. ${ }^{1}$

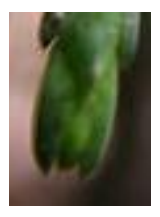

\section{Cones:}

$1 / 4^{\prime \prime}$ to $1 / 2$ " long, reddish-brown, glaucous, with 4 to sometimes 6 scales. ${ }^{2}$

\section{Twigs:}

Rounded to quadrangular and pendulous, slender, green at first, turning yellowish brown, and finally brown with age. ${ }^{3}$

\section{Buds:}

Very small, scaly, and greenish yellow. ${ }^{4}$
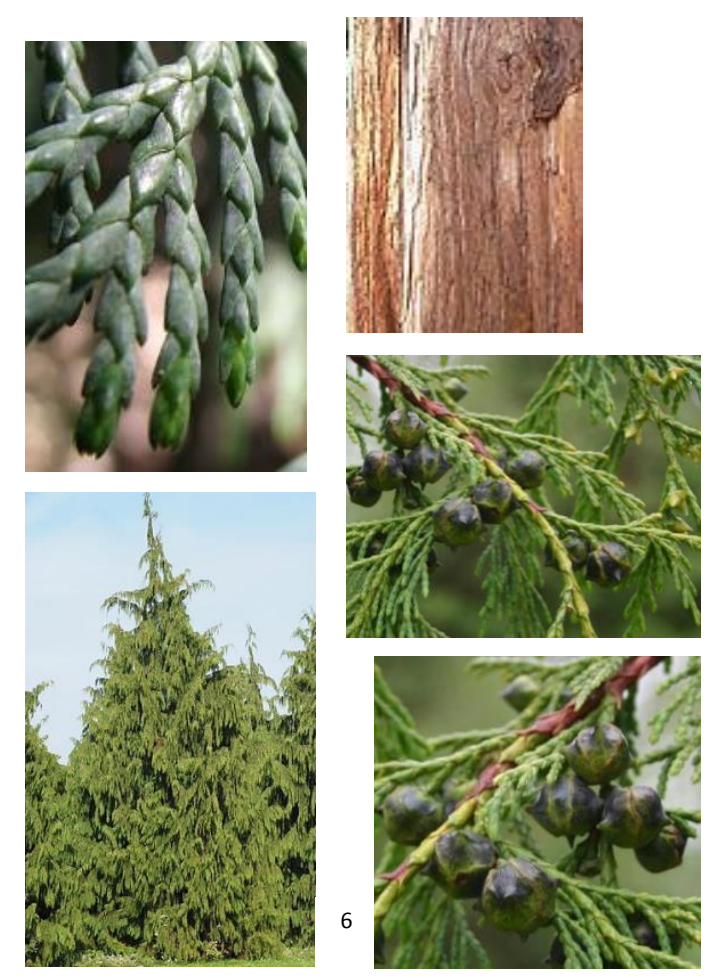

Alaska cedar is tolerant of shade and has a slow growth rate. It reaches a heigı of 70 to 100 feet and a diameter of 2 to 3 feet. Its pendulous branches give it a characteristic drooping appearance. Alaska cedar is an important timber species and its wood is used for cabinetry, interior and exterior finish, and furniture. The wood is yellow-brown in color. Needles lack whitish $\mathrm{x}$ markings on their undersides. Bark is grey in color. Alaska cedar is also planted as an ornamental. 
Port-Orford-cedar

\section{Chamaecyparis lawsoniana}

\section{Cupressaceae}

\section{Needles:}

$1 / 16^{\prime \prime}$, scalelike, yellow-green to blue-green with whitish $\mathrm{x}$ markings on the undersides. ${ }^{1}$

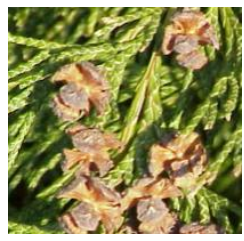

\section{Cones:}

$1 / 3^{\prime \prime}$ in diameter; reddish-brown; glaucous with 8 scales; Scales are wedge shaped. ${ }^{2}$

\section{Twigs:}

Appear in flat sprays, green at first, turning greyish brown, slender. ${ }^{3}$

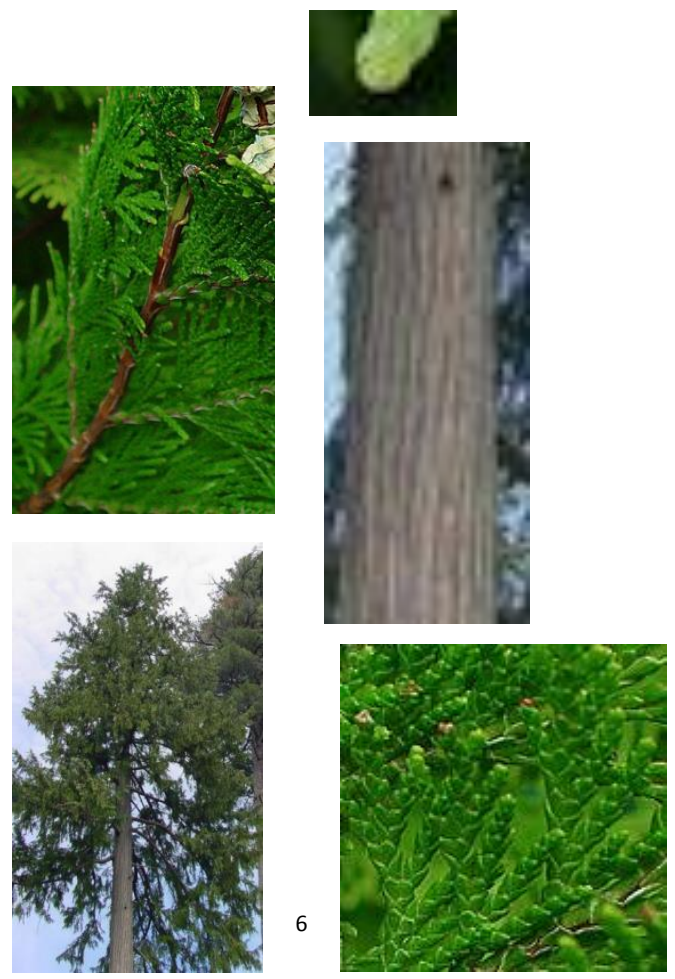

Port-Orford-cedar is tolerant of shade and has a moderate growth rate. It giuvvs to a height of 140 to 180 feet and reaches a diameter of 4 to 6 feet. It is also called Lawson cypress. It is used for timber and is often planted for ornamental purposes. Crown is composed of slightly pendant branches.

1: Photo courtesy of http://commons.wikimedia.org/wiki/File:Chamaecyparis_lawsoniana_002.JPG

2: Photo courtesy of http://commons.wikimedia.org/wiki/File:Chamaecyparis_lawsoniana5.jpg

3: Photo courtesy of http://commons.wikimedia.org/wiki/File:Chamaecyparis_lawsoniana_002.JPG

4: Photo courtesy of http://commons.wikimedia.org/wiki/File:Chamaecyparis_Lawasoniana_-_Stewartii_-_detail.jpg 
Atlantic white-cedar

\section{Chamaecyparis thyoides}

\section{Cupressaceae}

\section{Needles:}

No longer than $1 / 8^{\prime \prime}$, dark blue-green, scalelike, whitish $\mathrm{x}$ markings present on the undersides. ${ }^{1}$

\section{Cones:}

$1 / 4 "$ in diameter; bluish-purple; glaucous, wrinkled and plump with 4 to sometimes 6 scales. $^{2}$

\section{Twigs:}

Slender, not always flattened, green at first, becoming brown and smooth. ${ }^{3}$

\section{Buds:}

Very small and green. ${ }^{4}$
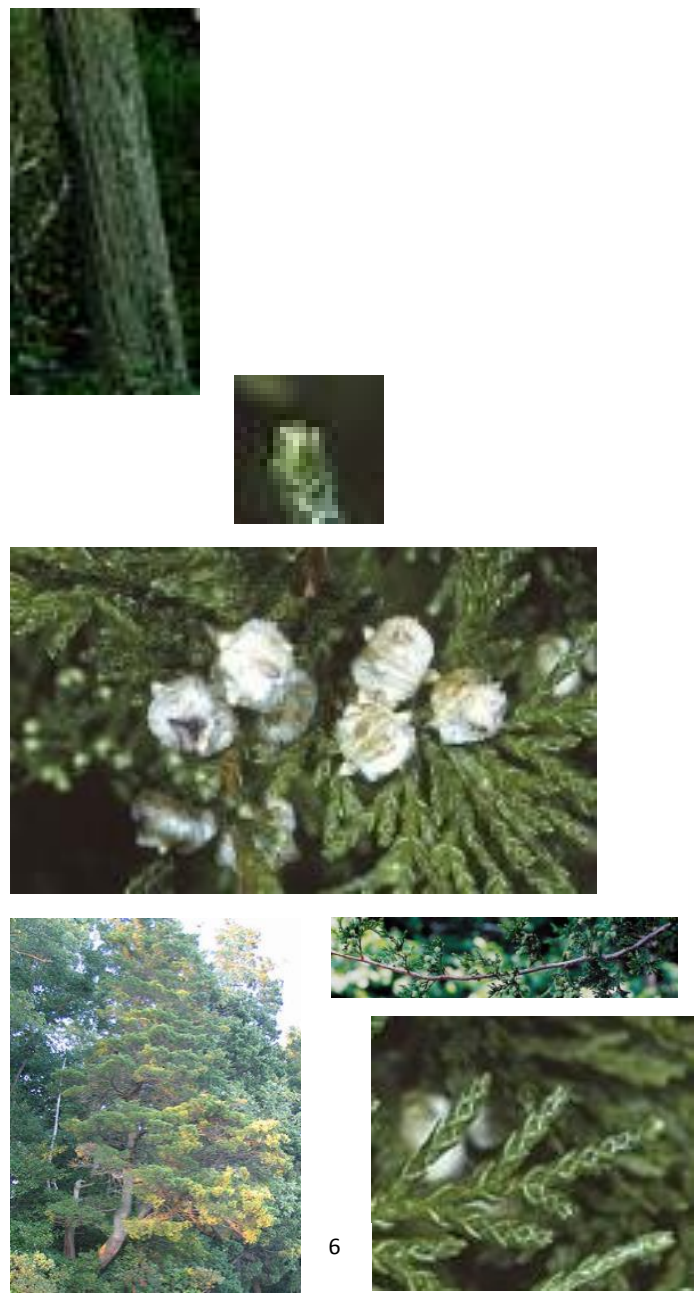

Atlantic white-cedar is tolerant of shade and has a moderate growth rate. It geırerally grows to a height of 80 to 85 feet and reaches a diameter of 1 to 1.5 feet. It prefers to grow in fresh-water swamps near the coast. It is sometimes used as an ornamental and many cultivars exist. Its wood is quite durable. 
Eastern redcedar

Juniperus virginiana

Cupressaceae

\section{Needles:}

$1 / 16^{\prime \prime}$ (adult), 1/8" to $3 / 4^{\prime \prime}$ (juvenile), dark green, scalelike (adult) and needlelike (juvenile); fragrant.

\section{Cones:}

$1 / 4$ to $1 / 3^{\prime \prime}$ in diameter; pale green to dark blue; glaucous, fleshy and berrylike; dioecious. ${ }^{1}$

\section{Twigs:}

Slender, green at first, becoming greyish brown and smooth with age.

\section{Buds:}

Very small, scaly, greenish yellow.
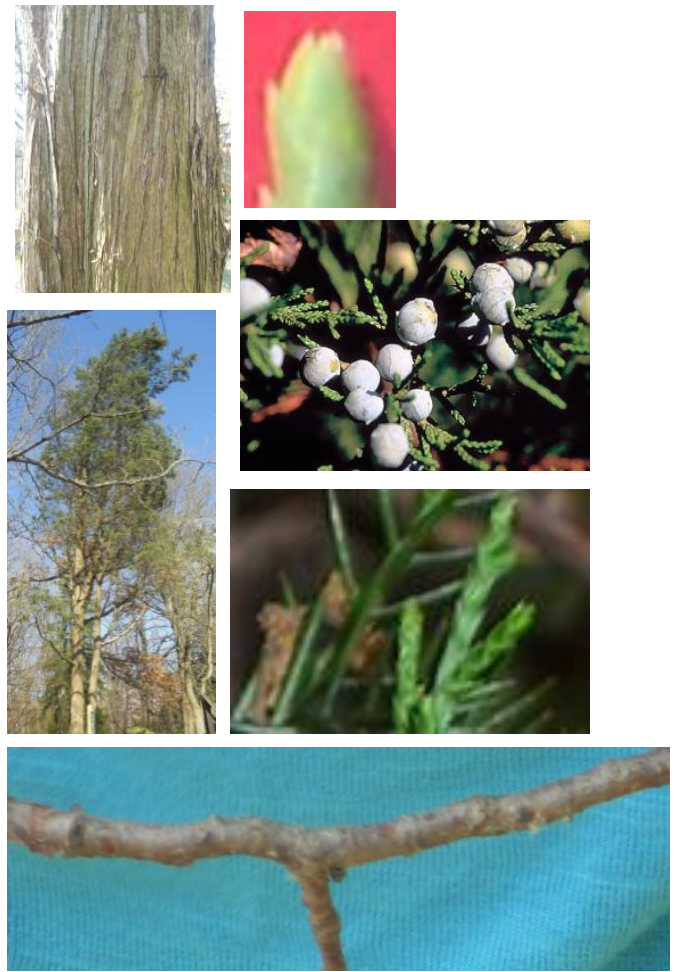

Eastern redcedar is intolerant of shade and has a slow growth rate. It generally grows to a height of 40 to 50 feet and reaches a diameter of 1 to 2 feet. It prefers to grow on limestone soils, but will tolerate a fairly wide range of sites. Its aromatic, durable wood is used for furniture, interior finishing, and several other uses. It is also used as an ornamental. 
Pacific yew

Taxus brevifolia

Pinaceae

\section{Needles:}

1 1", dark yellow-green to blue-green, pale below; Needles arranged spirally on the stem, but with the leaf bases twisted to align the leaves in two flat rows except on erect leading shoots. ${ }^{1}$

\section{Fruit:}

Ovoid-oblong, green seed partially surrounded by a scarlet, fleshy aril. ${ }^{2}$

\section{Twigs:}

Green at first, becoming reddish brown. ${ }^{3}$
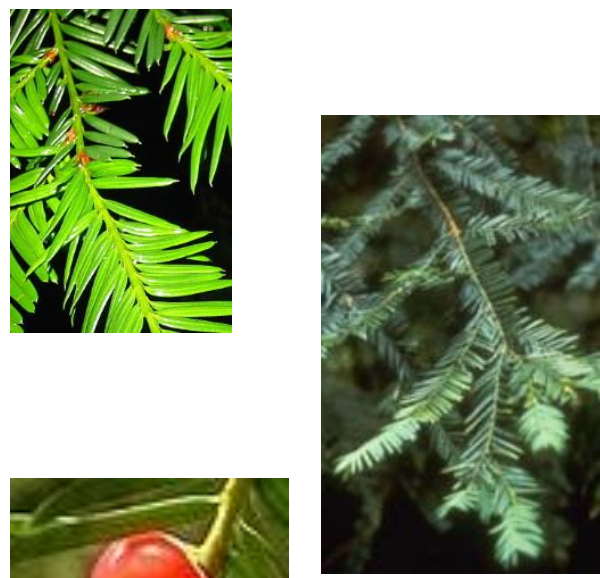

\section{Buds:}

Leaf buds are green, and very small. ${ }^{4}$
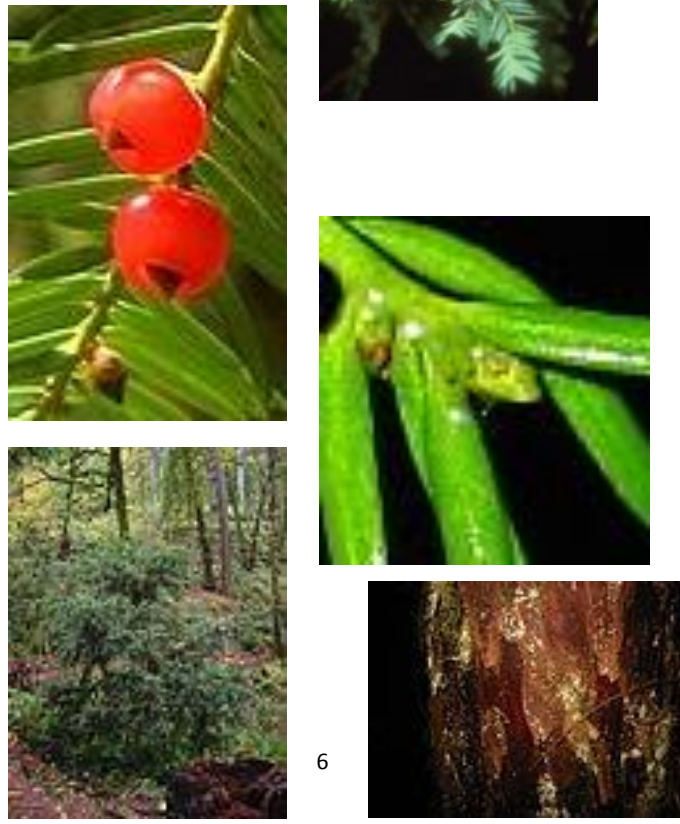

Pacific yew is tolerant of shade and has a very slow growth rate. It generally reaches a height of 20 to 40 feet and a diameter of 1 to 2 feet. Buds which develop into cones are larger and rounded. Young twigs are covered by the bases of leaves. It is not abundant in its native range. It grows on moist, rich sites. Pacific yew is a source of taxol, a chemical used in chemotherapy. It is also used as an ornamental.

1: Photo courtesy of http://commons.wikimedia.org/wiki/File:PacificYew_8538.jpg

2: Photo courtesy of http://commons.wikimedia.org/wiki/File:Taxus_brevifolia_Blue_Mts_WA.jpg

3: Photo courtesy of http://commons.wikimedia.org/wiki/File:Taxus_brevifolia1.jpg

5: Photo courtesy of http://commons.wikimedia.org/wiki/Taxus_brevifolia 
Ginkgo, Yin xing

Ginkgo biloba

Ginkgoaceae

\section{Leaves:}

Deciduous, alternate, simple, flabellate (fan-shaped), 1 "-2" long, $1 \frac{112 "}{2}-3$ " wide; one or more apical sinuses, glabrous.

Fruit:

Large, 1" diameter, dioecious; tan to yellowish in color, outer fleshy seed coat, foul odor when ripe. ${ }^{1}$

\section{Twigs:}

Stout, brown to gray in color with stringy bark; Conspicuous spurs present along older twigs.

\section{Buds:}

Represent scaly buds, terminal bud present, leaf scars raised, half round with two bundle scar, brown in color.
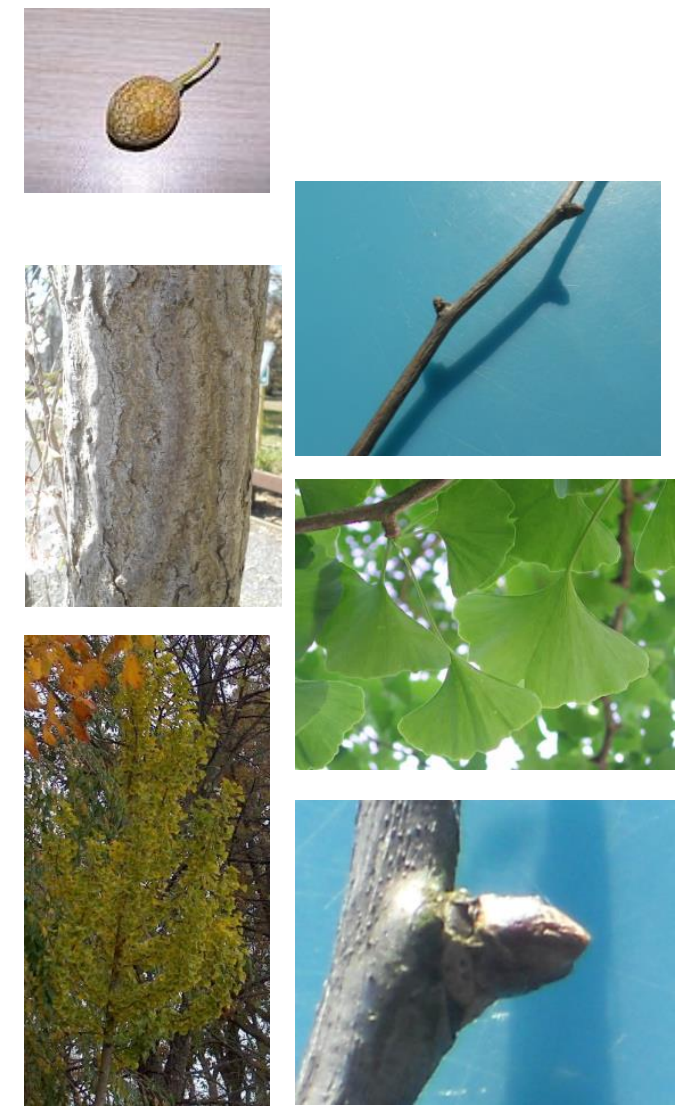

Ginkgo is tolerant of shade and has a moderate growth rate. It reaches a height of 100 feet and a diameter of 3 feet. Because of the foul odor given off by the fruits, male trees are planted more frequently than female trees. A large white seed can be found inside the fruits. Leaves turn a clear yellow in the fall. Ginkgo develops a large spreading crown with age. Several cultivars exist which may appear in landscapes. 
Southern magnolia

Magnolia grandiflora

Magnoliaceae

\section{Leaves:}

Alternate, 5" to 10 "long, 2" to 3 " wide, leathery, evergreen, bright green in color, smooth, very lustrous. ${ }^{1}$

\section{Flowers/Fruit:}

Flowers are $6 "$ to 9 " in diameter with 6 to 12 white petals ${ }^{2}$; fruit is $3^{\prime \prime}-8$ " long, an elongated aggregate of follicles, rusty, hairy; seeds are reddish orange in color. $^{3}$

\section{Twigs:}

Rusty, hairy, and stout. ${ }^{4}$

\section{Buds:}

$1 / 4^{\prime \prime}-1 \frac{1}{2}$ " pale to rusty, hairy; flower buds larger than leaf buds. ${ }^{5}$
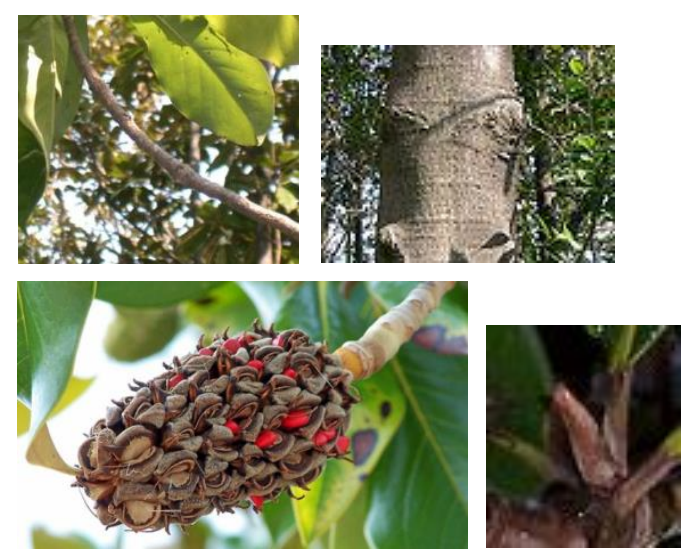

\section{than leaf buds.}
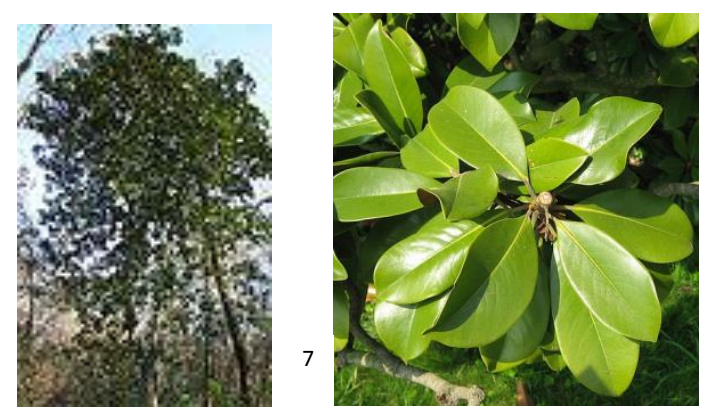

Southern magnolia is intolerant of shade and has a moderate growth rate. I i eaches a height of 25 to 80 feet and a diameter of 2 to 3 feet. Its crown is typically pyramidal to rounded. Although often associated with only the southeastern United States, Southern magnolia will grow well in colder climates much further north than its native range. It is frequently used as an ornamental and many cultivars exist. 


\section{Cucumber-tree}

Magnolia acuminata

Magnoliaceae

\section{Leaves:}

Alternate, 6-10" long, yellow-green in color, broadly elliptical, entire; decicuous.

\section{Flowers/Fruit:}

Flowers are 1 to 2.5 inches long, with 3 sepals and 6 greenish yellow petals; fruit is $2-3$ " long, an aggregate of follicles, pinkish red in color, with red seeds.

\section{Twigs:}

Brown to red-brown, glabrous, with U-shaped leaf scars.

\section{Buds:}

1/4"-3/4" long, silvery-green and silky.
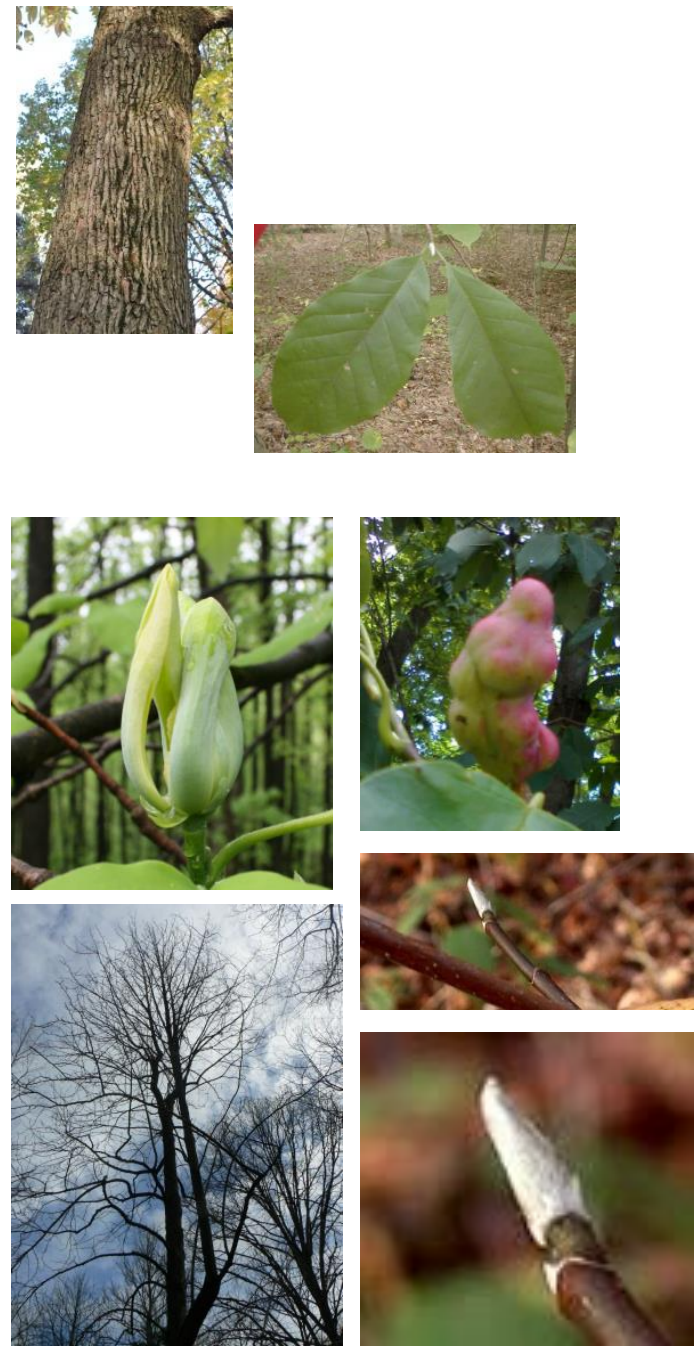

Cucumber-tree is intolerant of shade and has a moderately rapid growth rate. It grows 40 to 90 feet in height and attains a diameter of 3 to 4 feet. Leaves turn yellow to brown in the fall. It generally has a pyramidal shaped crown, but with age, becomes rounded and spreading. Flowers typically appear in the upper portions of the crown and are not showy. Cucumber-tree is used for timber which is sold as Yellow-poplar. Leaves, twigs, etc. emit a lemon-like odor when crushed. 


\section{Yellow-poplar, Tuliptree}

\section{Liriodendron tulipifera}

Magnoliaceae

\section{Leaves:}

Alternate, 4-6" long, 4-lobed, entire margin, bright green in color, deciduous, turning a clear yellow in the fall.

\section{Flowers/Fruit:}

Flowers are tulip-shaped, 1.5" to 2.5" across, 2" to 3" high with 6 greenish yellow petals; fruit is $21 / 2-3^{\prime \prime}$ long, erect, cone like aggregate of samaras; brown when mature.

\section{Twigs:}

Twigs moderately stout, reddish brown.

\section{Buds:}

Valvate, $1 / 2$ " long, duck-bill appearance, glabrous.
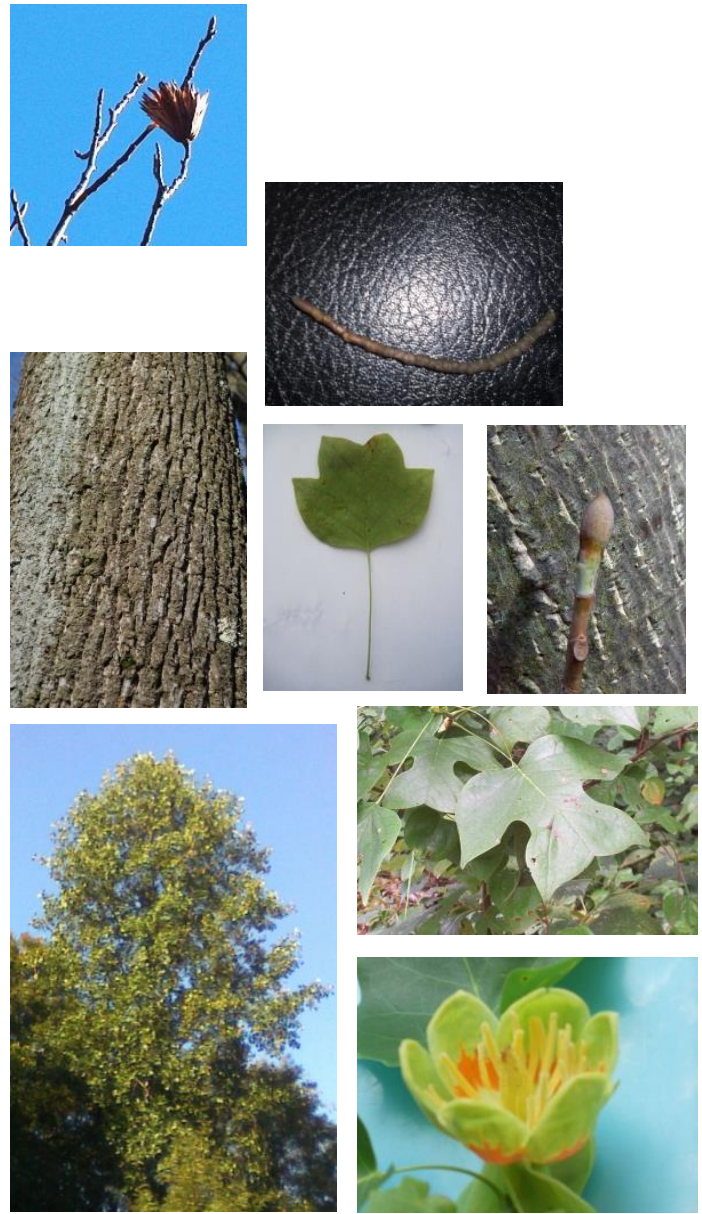

Yellow-poplar is intolerant of shade and has a rapid growth rate. It grows to a height of 80 to 150 feet and a diameter of 4 to 6 feet. Flowers appear in late spring; the greenish yellow petals have orange coloring at the bases. Crown is pyramidal and trunk is typically very straight. Yellow-poplar is one of the most important timber trees in the eastern United States. The wood is often reported as being weak and the tree, susceptible to breakage from storms, ice, etc. However, this characteristic seems variable throughout its large range. 
Sassafras

Sassafras albidum

Lauraceae

\section{Leaves:}

Alternate, 4" to 6" long, varied shapes, mitten like with two, three, or no lobes, entire, elliptical; pleasant spicy odor, deciduous.

\section{Flowers/Fruit:}

Flowers are yellow to greenish-yellow, with five or six sepals ${ }^{1}$; fruit is a blue drupe, $3 / 10^{\prime \prime}$ long.

\section{Twigs:}

Yellow-green in color.
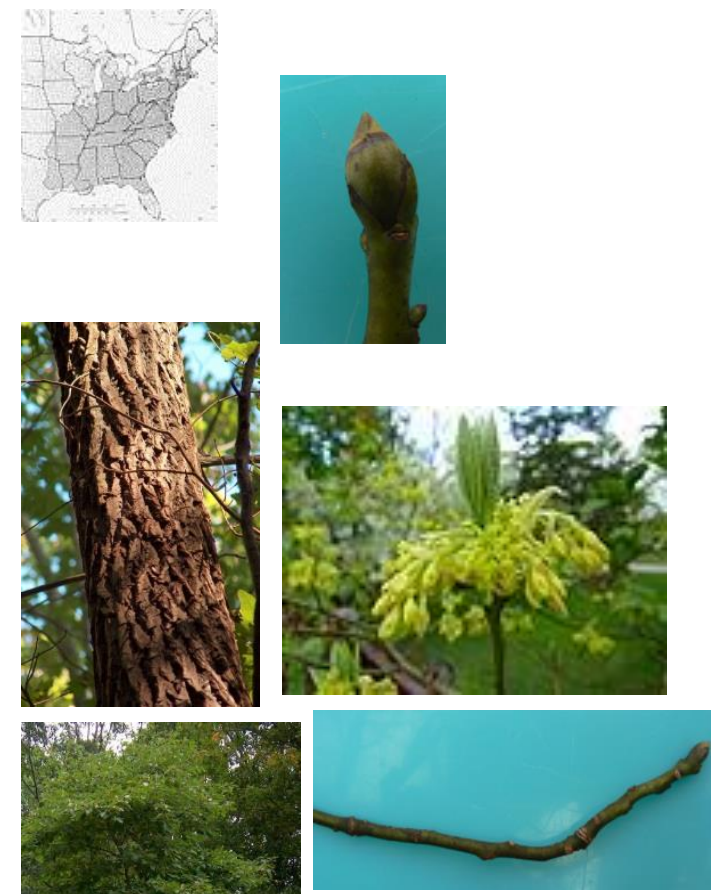

\section{Buds:}

$1 / 3^{\prime \prime}$ long, bright yellow green at first, turning reddish brown.
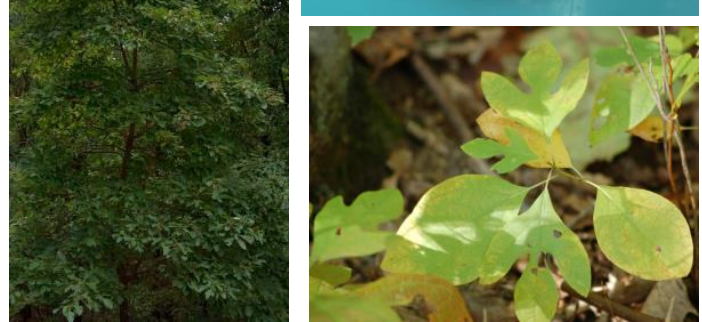

Sassafras is intolerant of shade and has a rapid growth rate. It reaches a height of 40 to 70 feet and a diameter of 2.5 to 3 feet. All parts of the plant emit a spicy odor when bruised, crushed, etc. Sassafras has a pyramidal shaped crown in youth, becoming irregular and flat-topped with age. Sassafras tea can be made from boiling the roots. Fall color can be red, orange, yellow, and all shades in between. Flowers are usually dioecious, with male and female flowers on separate trees. Sassafras often sprouts from the roots. 
Platanaceae

\section{Leaves:}

Alternate, 5" to 8" long, palmately lobed (usually 5), blade wider than long, margin coarsely toothed, deciduous.

\section{Flowers/Fruit:}

Flowers are in rounded structures, not showy; fruits are round and fused, an aggregate of achenes, on a 3" to $6 "$ long stem.

\section{Twigs:}

Zigzag, stout, yellow brown to orangish brown.

\section{Buds:}

$1 / 4^{\prime \prime}$ to $3 / 8^{\prime \prime}$, smooth, nearly surrounded by leaf scar.
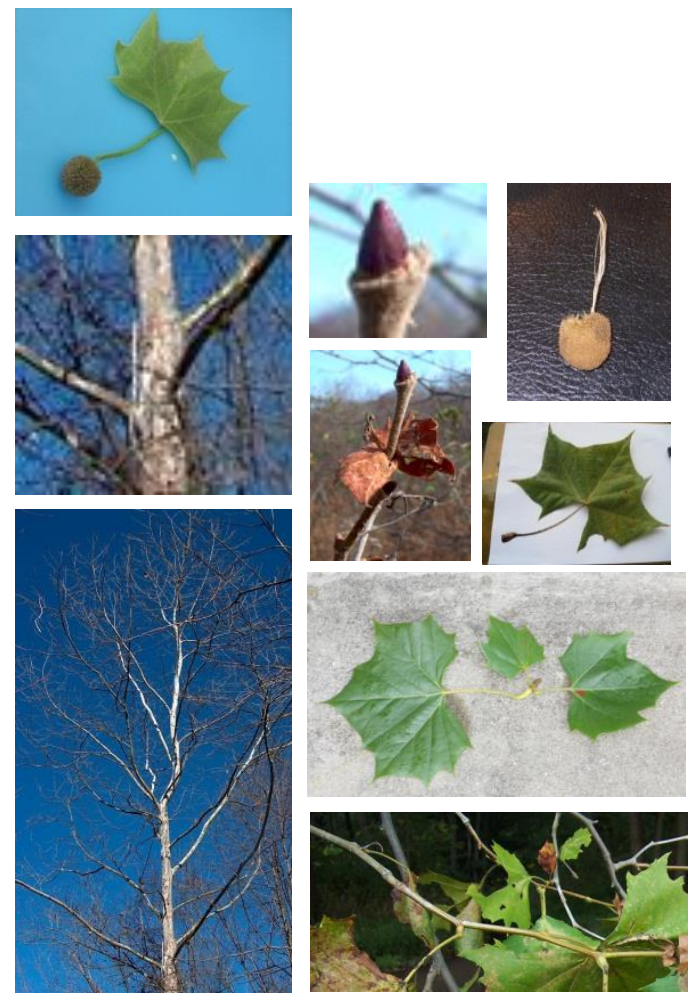

American sycamore is intolerant of shade and has a rapid growth rate. It reaches a height of 100 to 170 feet, and a diameter of 3 to 10 feet. It typically has a pyramidal to cone shaped crown in youth, but becomes rounded, wide, and spreading with age. Fall color is usually a dull brown, but may be yellow. Twigs are smooth. Its wood, used for timber is heavy and hard. Often associated with wet conditions, it will perform well on a variety of sites. Due to its susceptibility to sycamore anthracnose, it may develop an excessive zigzag growth pattern. 
Witch-hazel

Hamamelis virginiana

Hamamelidaceae

\section{Leaves:}

4" to 6" long, 2" to 3" wide, simple, alternate, dark green, with wavy, toothed margins; deciduous.

\section{Flowers/Fruit:}
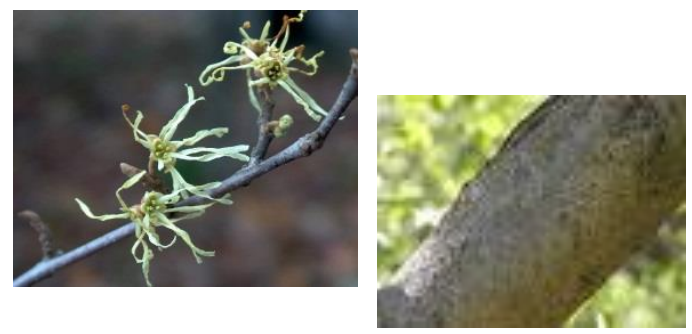

Flowers are yellow, have 4 slender petals, and bloom late in fall; fruits are $1 / 2$ " long, a 2-beaked capsule, seeds expelled when dry.

\section{Twigs:}

Twigs are brownish to grey, pubescent when young, becoming glabrous with age.

\section{Buds:}

$1 / 4 "$ to $1 / 2 "$ long, brown, naked, tomentose.
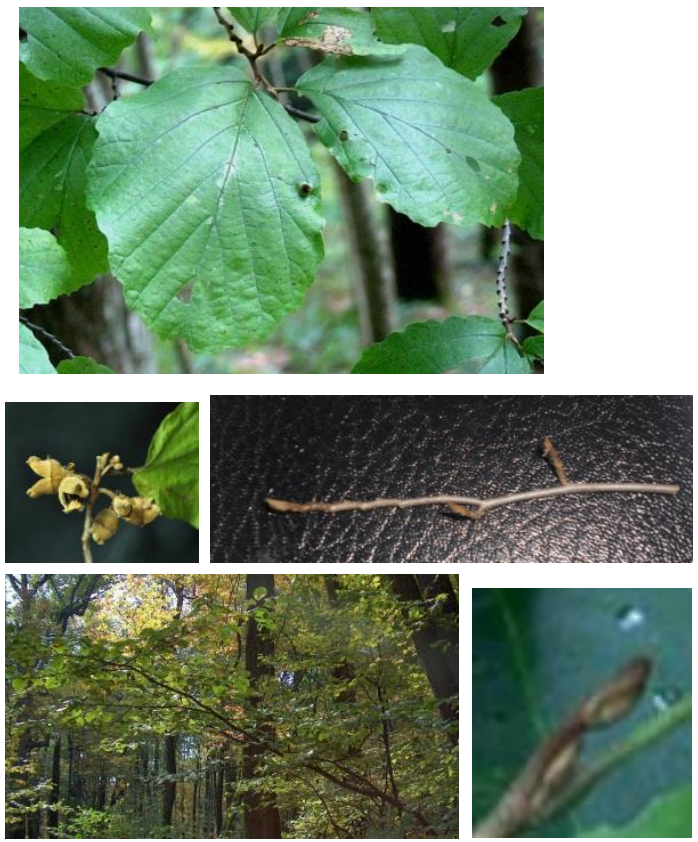

Witch-hazel is tolerant of shade and has a slow growth rate. Witch-hazel is a shrub to small tree growing to a height of 15 to 30 feet, and a diameter of 6" to 12 ". It typically is composed of wide spreading branches, giving it a rather rounded to flat-topped crown. It grows best on moist sites near streams, but will tolerate dry upland sites as well. An extract, used in mildly astringent lotions, can be obtained from the leaves. Leaves turn yellow in the fall. 
Sweetgum

Liquidambar styraciflua

Hamamelidaceae

\section{Leaves:}

5" to 7"long and wide, star-shaped, deeply palmate 57 lobed, margin finely serrate, alternate arrangement; deciduous.
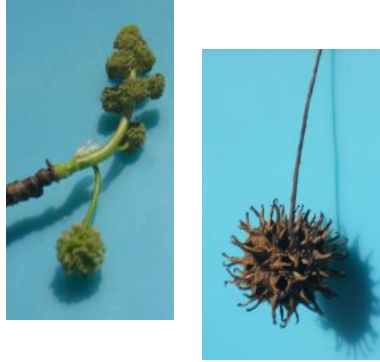

Flowers/Fruit:

Flowers are greenish in color, not showy; fruit is $1-1$ $1 / 2$ " diameter, a head of strongly beaked capsules, brown in color.

Twigs:

Shiny green to yellow-brown, aromatic, often have corky excrescences (wings).

\section{Buds:}

$1 / 4 "-1 / 2 "$ long with orange brown scales.
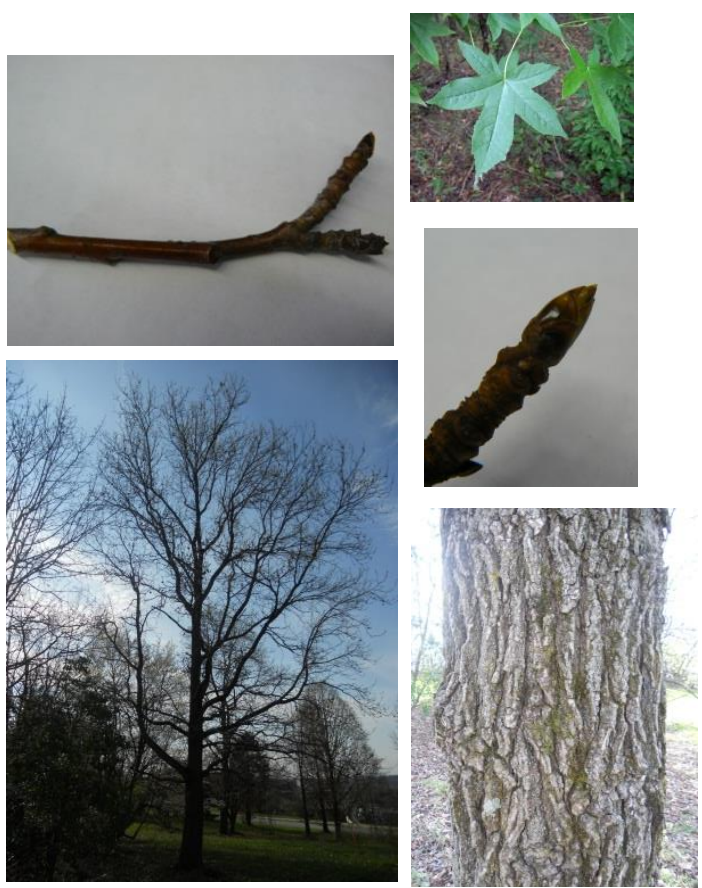

Sweetgum is intolerant of shade and has a rapid growth rate. It reaches a height of 80 to 120 feet and a diameter of 3 to 5 feet. Often associated with the southeastern U.S., it is the most commonly found species of tree in the Mississippi delta. It is used for timber, and is frequently planted as an ornamental. Fall color is various shades of yellow, orange, and red. It typically has a pyramidal shaped crown in youth, but becomes rounded and spreading with age. 
American elm

Ulmus americana

Ulmaceae

\section{Leaves:}

4" -6 " long, alternate, oblong, coarsely doubly serrate, base unequal, pubescent below; deciduous.
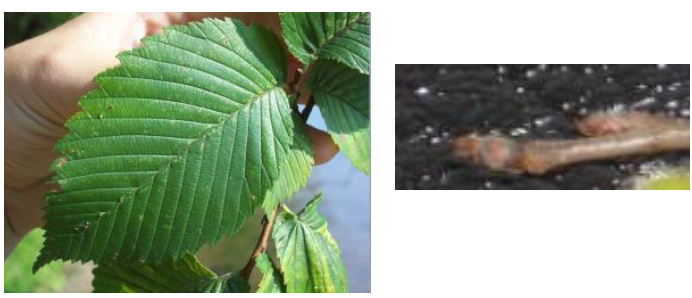

\section{Flowers/Fruit:}

Flowers are reddish green in color and appear in late winter to early spring; fruit is $1 / 2$ " long, a samara, green at first, turning brownish matures in spring, margin of wing hairy.

\section{Twigs:}

Slender, zigzag, smooth, brown.

\section{Buds:}

$1 / 4 "$ long, acute, chestnut brown, terminal is absent.
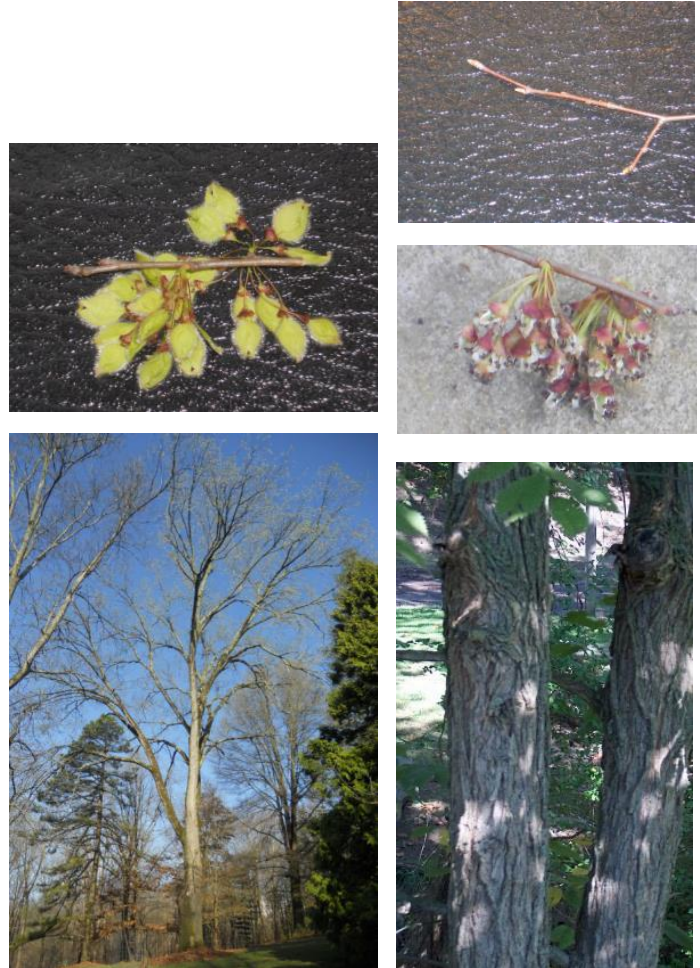

American elm is intermediate in shade-tolerance and has a rapid growth rate. It generally grows to a height of 80 to 100 feet and a diameter of 2 to 4 feet. Susceptible to Dutch elm disease. It is sometimes assumed that American elm is rare due to Dutch elm disease, however many trees exist due to most individuals surviving long enough to produce seeds for reproducing the species, and the development of resistant cultivars. Crown often becomes vase-like in shape. Leaves turn yellow to brown in the fall. 


\section{Slippery elm, Red elm}

Ulmus rubra

Ulmaceae

\section{Leaves:}

5" -7 " long, alternate, elliptical, coarsely double serrate, base unequal, surfaces very scabrous; deciduous.
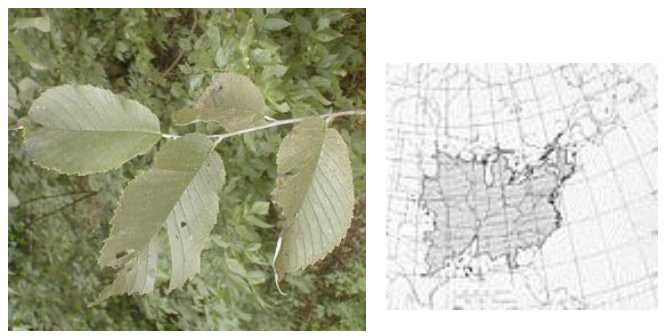

\section{Flowers/Fruit:}

Flowers are brownish in color and appear in late winter to early spring; fruit is $3 / 4$ " across, a samara, greenish yellow, matures in spring with leaf opening, margin of wing smooth.

\section{Twigs:}

Stouter than American elm, ash gray to brown.

\section{Buds:}

$1 / 4$ " long, reddish to dark brown, terminal absent.
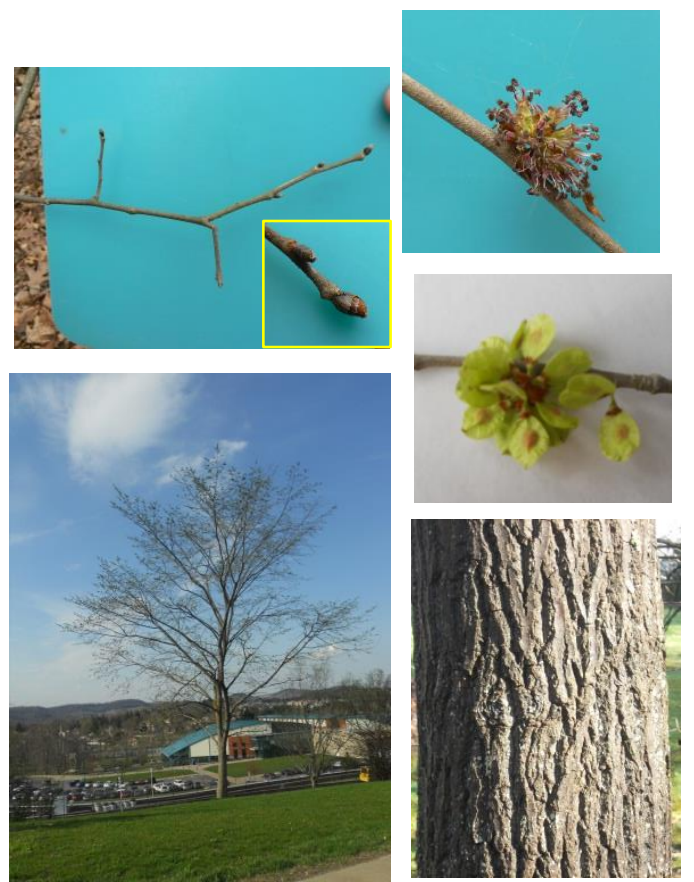

Slippery elm is intermediate in shade-tolerance and has a rapid growth rate. It reaches a height of 60 to 80 feet and a diameter of 1 to 3 feet.It may develop a vase-like crown, but is often upright in form with a flat-topped or V-shaped crown. It is susceptible to the Dutch elm disease, but as with American elm, many individuals exist due to its ability to produce seed at a young age. Leaves may turn a dull yellow color in the fall, but often drop without any noticeable color. Its inner bark can be used in cough medicine. 
Hackberry

Celtis occidentalis

Ulmaceae

\section{Leaves:}

$2 \frac{1}{2}-4$ " long, alternate, ovate, sharply serrate except near base, base unequal, undersurface scabrous

(sandpaper like); deciduous.

\section{Flowers/Fruit:}

Flowers are small, greenish in color, not showy ${ }^{1}$; fruit is $1 / 3^{\prime \prime}$ in diameter, dark purple to black drupe, maturing in the fall. ${ }^{2}$

\section{Twigs:}

Slender, zigzag, and reddish brown.

\section{Buds:}

Up to $1 / 4$ " long,small, sharp pointed, grey to brown in
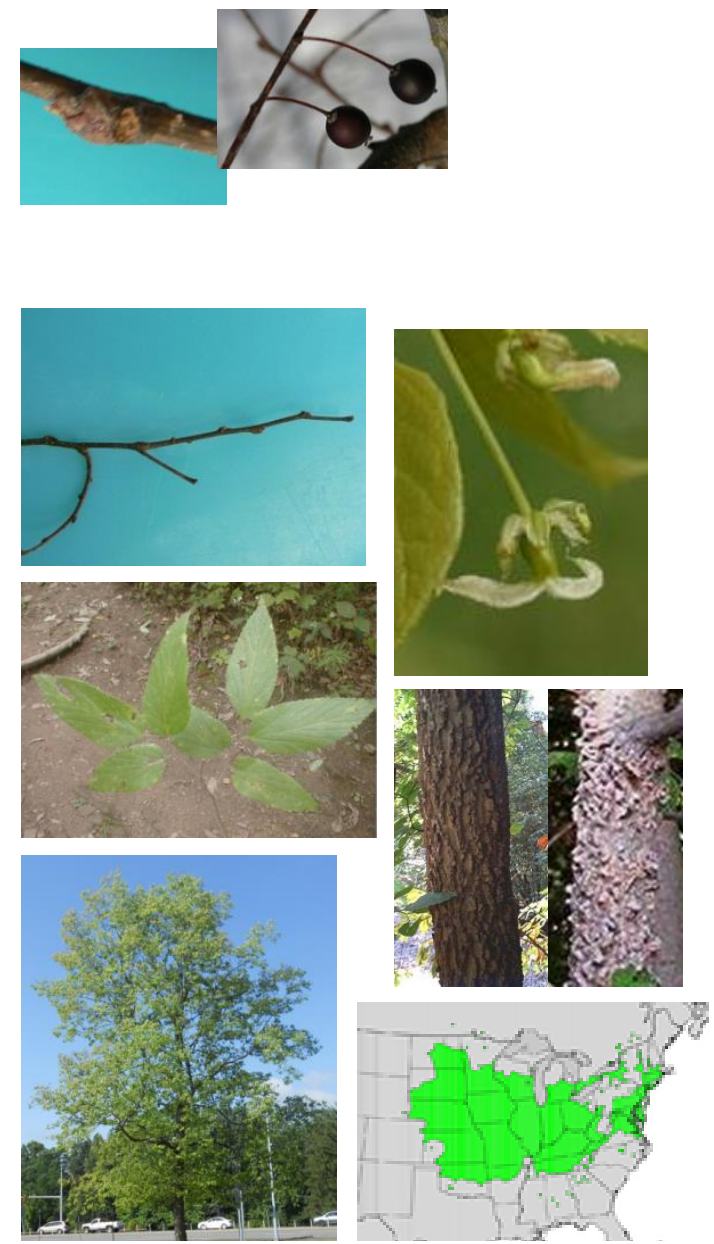

Hackberry is intermediate in shade-tolerance, and has a moderate to fast growth rate. It generally reaches a height of 50 to 90 feet and a diameter of 1 to 2 feet. Leaves may turn yellow in the fall, but often drop without significant color change. Fruit often persists into the winter. Hackberry can be easily distinguished by its corky bark. Leaves often have galls present. Hackberry will grow on just about any site and tolerates wind, drought, and other stress well.

\footnotetext{
1: Photo courtesy of http://commons.wikimedia.org/wiki/File:Celtis-occidentalis-flower.jpg

2: Photo courtesy of http://commons.wikimedia.org/wiki/File:Celtis-occidentalis-fruits.JPG

3: Image courtesy of http://commons.wikimedia.org/wiki/Celtis occidentalis
} 


\section{Leaves:}

Alternate, 4" to 6" long, serrate, pubescent, varied form from no lobes to deeply lobed, not shiny; deciduous. $^{1}$

\section{Flowers/Fruit:}

Flowers are small, yellowish green, and appear in the spring; fruit is1" to $1.5^{\prime \prime}$ long, oblong, red or purple, collection of small drupes, edible. ${ }^{2}$

\section{Twigs:}

Twigs have continuous pith, and are brown.
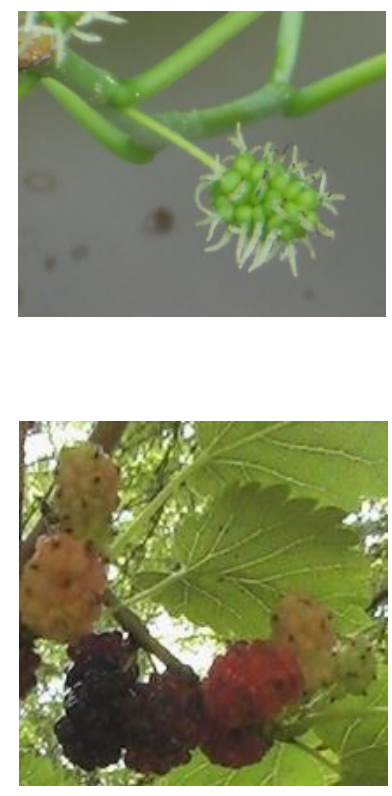

\section{Buds:}

$1 / 4$ “long, shiny, greenish brown.
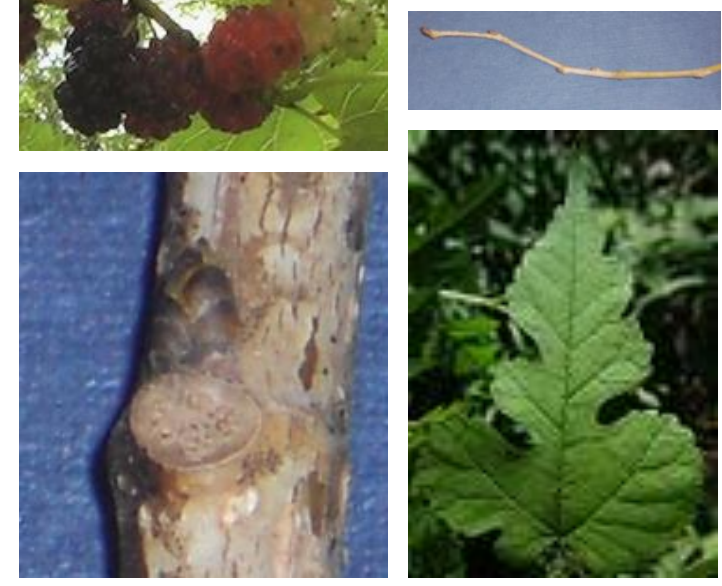

Red mulberry is tolerant of shade and has a moderate growth rate. It generally reaches a height of 50 to 70 feet and a diameter of 2 to 3 feet. It has a dense, rounded crown. Leaves turn yellow in the fall. It can be separated from White mulberry (Morus alba), by its leaves, which are not shiny. Red mulberry grows best on moist sites.

\footnotetext{
1: Photo courtesy of http://commons.wikimedia.org/wiki/Morus_rubra

2: Photo courtesy of http://commons.wikimedia.org/wiki/File:Mulberries_in_the_US.jpg
} 
Black walnut

Juglans nigra

Juglandaceae

\section{Leaves:}

Alternate; 12 " -24 " long, 15 to 23 nearly sessile leaflets, deciduous, terminal leaflet small or absent, petiole, rachis and surfaces variably hairy; deciduous, turning yellow in the fall.

\section{Flowers/Fruit:}

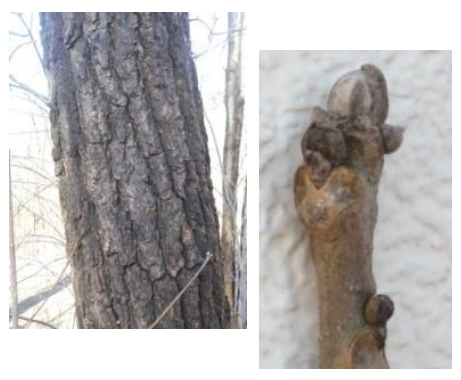

Flowers are monoecious; fruit is $1 \frac{1}{2} "-2$ ", a nut, yellowish-green husk, edible seed is sweet.

\section{Twigs:}

Stout, grey to reddish brown.

\section{Buds:}

$1 / 4^{\prime \prime}$ to $1 / 3^{\prime \prime}$, short, blunt pubescent, grey in color.

\section{Bark:}

Dark brown; deep, narrow furrows, diamond-shaped pattern.

\section{Distribution in North America:}

Native from New England, south to Florida, west to Texas and South Dakota.

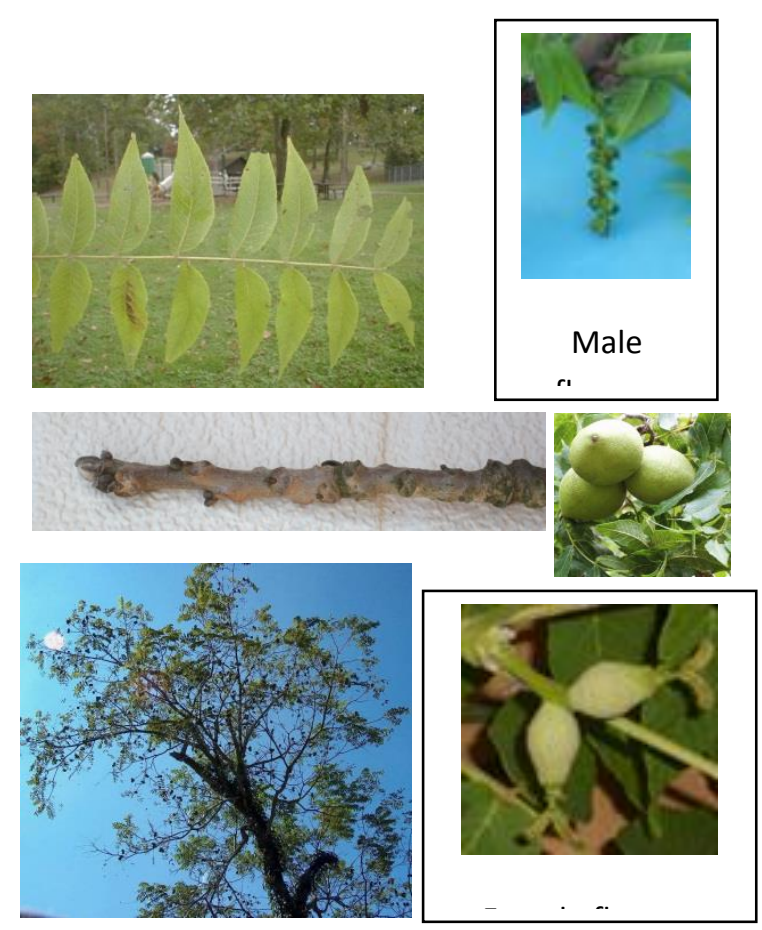

Black walnut is very intolerant of shade and has a moderate growth rate. It generally reaches a height of 70 to 100 feet and a diameter of 2 to 3 feet. The flowers are greenish in color, appear in spring, and are not showy; males appear in aments, and female flowers, in small spikes. Twigs have chambered pith. Black walnut is valued for its edible seeds and timber. Black walnut will grow on a variety of sites and produces a chemical called juglone which inhibits the growth of certain other species of plants. 
Butternut

Juglans cinerea

Juglandaceae

\section{Leaves:}

15 " to 30 " long, alternate, 11 to 17 nearly sessile leaflets, deciduous; stout pubescent rachis; terminal leaf present.
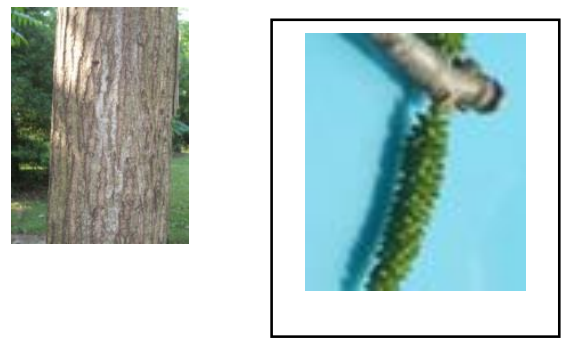

\section{Flowers/Fruit:}

Flowers are monoecious; fruit is $1 \frac{1}{2}{ }^{\prime \prime}$ to $21 / 2^{\prime \prime}$, egg shaped, greenish bronze, thick husk. Very oily, edible seed.

\section{Twigs:}

Stout, greenish gray to reddish brown, with chambered pith.

\section{Buds:}

$1 / 4^{\prime \prime}$ to $3 / 4 "$, gray brown, pubescent.
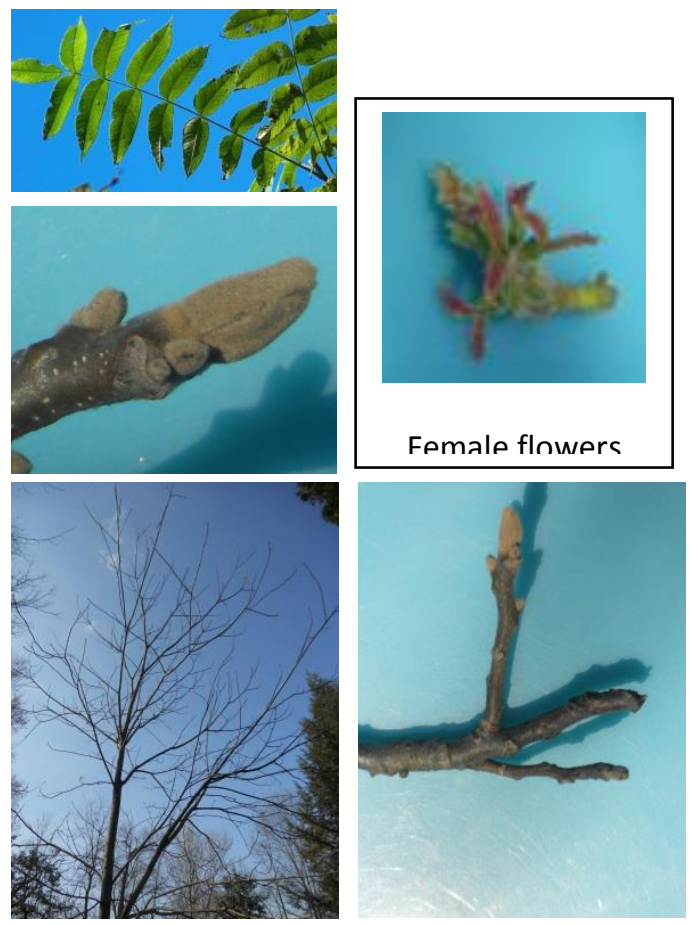

Butternut is intolerant of shade and has a moderate growth rate. It generally reaches a height of 50 to 60 feet and a diameter of 1 to 2 feet. Butternut's flowers appear in the spring, with males appearing in aments, and the females, in spikes. Leaves may turn yellow in the fall, but often drop without noticeable coloration. Its wood is used for timber. Butternut is threatened in much of its range with a canker disease, Sirococcus clavigignenti-juglandacearum. 
Pecan

\section{Carya illinoensis}

Juglandaceae

\section{Leaves:}

12 " to $20^{\prime \prime}$ long, alternate, pinnately compound with 9 -19 leaflets, serrate or doubly serrate, dark green in color; deciduous. ${ }^{1}$

\section{Flowers/Fruit:}

Flowers are greenish and appear as catkins in the spring ${ }^{2}$; fruit is a nut, $1.5^{\prime \prime}$ to $2^{\prime \prime}$ long, in clusters of $3-$ 12, ellipsoidal, dark brown husk with four winged sutures, maturing in autumn, edible. ${ }^{3}$

\section{Twigs:}

Moderately stout, reddish-brown, pubescent. $^{4}$
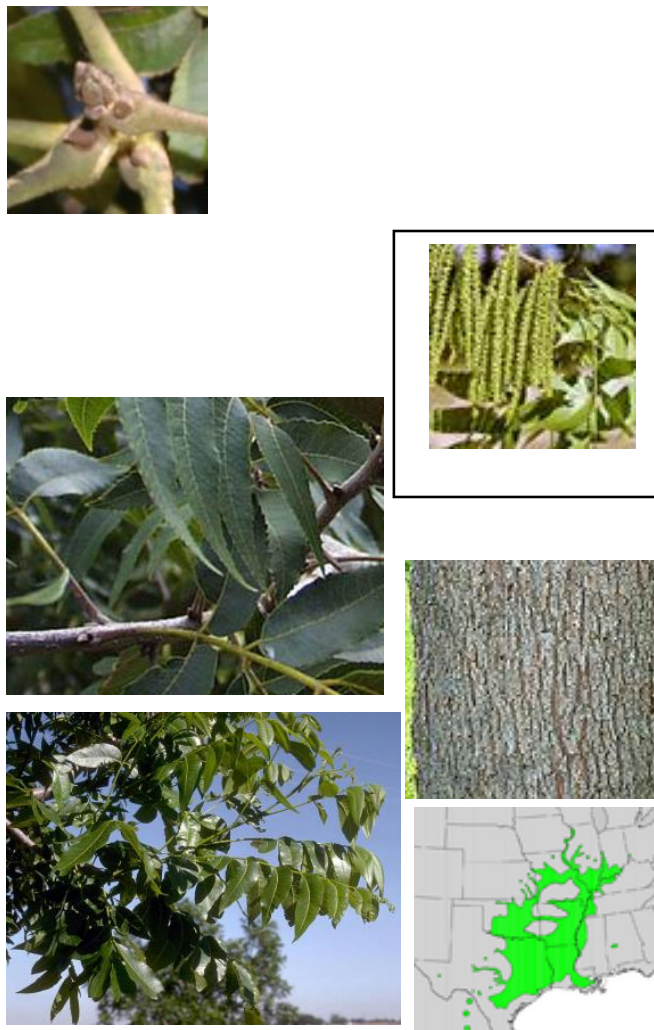

Buds:

$1 / 4^{\prime \prime}-1 / 2 "$, yellow-brown, hirsute, valvate.
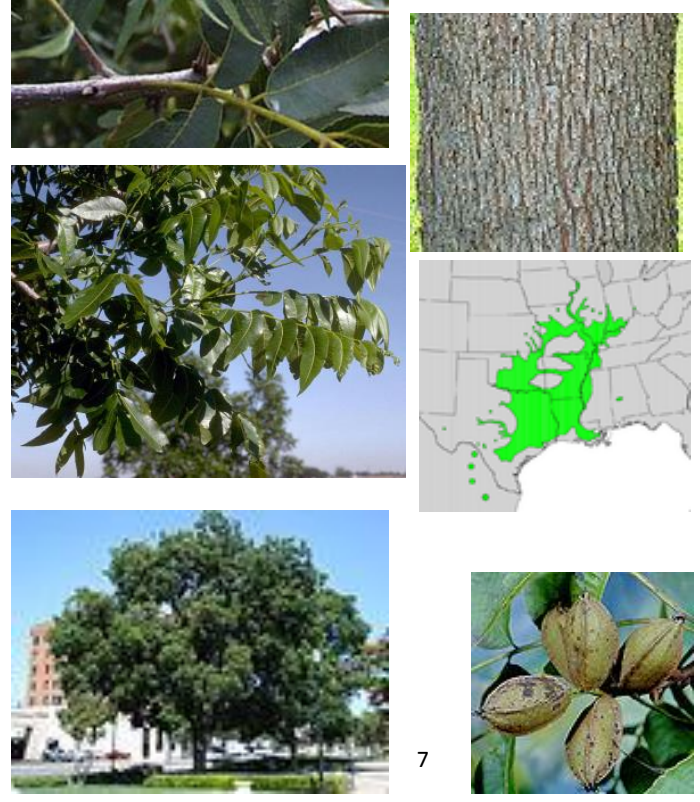

Pecan is tolerant of shade and has a slow growth rate. It grows quite large, reaching a height of 100 to140 feet and a diameter of 2 to 4 feet. Leaves turn yellow in the fall. The Pecan is valued for its edible fruits and is a commercial crop in the southern United States. Many cultivars exist. Pecan commonly grows on moist sites near large streams and rivers. Pecan is cold hardy to Zone 5 , but typically performs better in more southern areas. Pecan is a member of the pecan hickory group.

1: Photo courtesy of http://commons.wikimedia.org/wiki/File:Carya_illinoinensis_foliage.jpg

2: Photo courtesy of http://commons.wikimedia.org/wiki/Category:Carya_illinoinensis

3: Photo courtesy of http://commons.wikimedia.org/wiki/Category:Carya_illinoinensis

4: Photo courtesy of http://commons.wikimedia.org/wiki/File:Carya_illinoinensis_foliagenuts.jpg

5: Photo courtesy of http://commons.wikimedia.org/wiki/Category:Carya_illinoinensis

6: lamge courtesy of http://commons.wikimedia.org/wiki/Category:Carya_illinoinensis

7: Photo courtesy of http://commons.wikimedia.org/wiki/Category:Carya_illinoinensis 


\section{Bitternut hickory}

\section{Carya cordiformis}

Juglandaceae

\section{Leaves:}

7" to $10^{\prime \prime}$ long, alternate, pinnately compound with 7 11 leaflets, serrate, glabrous above, light to dark green, terminal leaflets 2-3 times the length of the proximal leaflets; deciduous.

\section{Flowers/Fruit:}

Flowers are greenish catkins that appear in the spring; fruit is 1 " long, a nut, winged along 4 sutures, bitter seed, maturing in the fall.

\section{Twigs:}

Moderately stout, greenish brown to gray-brown.

\section{Buds:}

$1 / 3^{\prime \prime}$ to $3 / 4 "$, valvate, mustard yellow, pubescent.
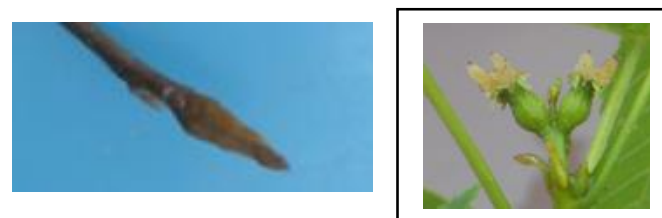

Female flowers
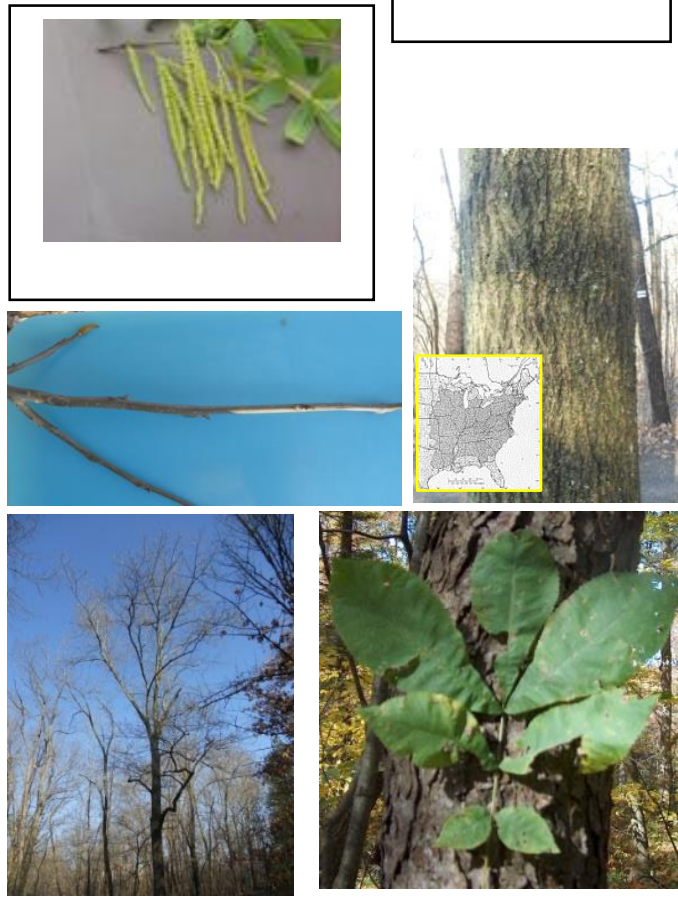

Bitternut hickory is tolerant of shade and has a fairly rapid growth rate. It grows 60 to 70 feet in height and 1 to 3 feet in diameter. Leaves turn yellow in the fall. Fruits are edible, but taste very bitter, hence its common name. An excellent ID feature is the yellow buds. It develops a cylindrical crown with age. It generally grows on moist sites. Bitternut hickory is a member of the pecan hickory group. 


\section{Shagbark hickory}

\section{Carya ovata}

Juglandaceae

\section{Leaves:}

$10-14$ " long, alternate, pinnately compound with 5 leaflets, terminal leaflets 5-8" long, glabrous above, yellow-green to dark green; deciduous.

\section{Flowers/Fruit:}

Flowers are greenish colored catkins that appear in the spring; fruit is 1 " to $2 \frac{1}{2}$ " diameter, a nut, reddish brown to black husk, no wings on sutures, edible seed. $^{1}$

\section{Twigs:}

Stout, gray-brown to reddish brown, hairy.

\section{Buds:}

$1 / 2-3 / 4$ " long, 3 or 4 dark brown pubescent scales.
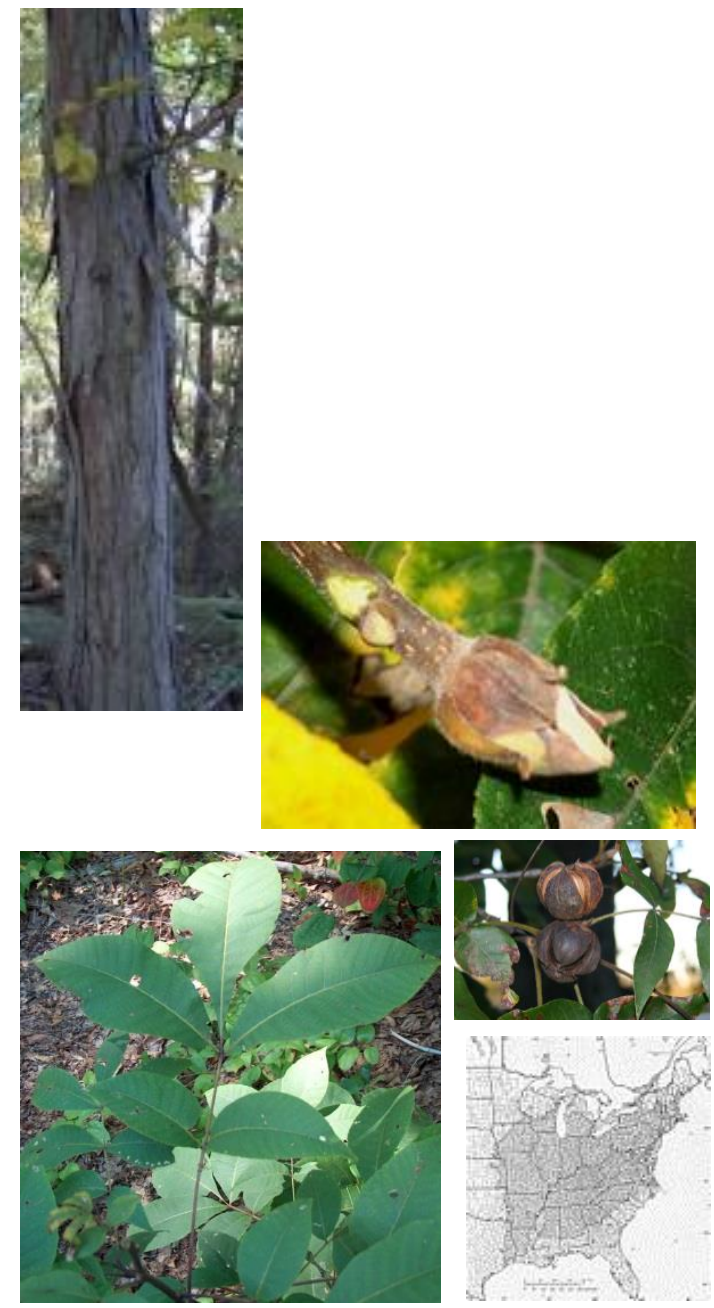

Shagbark hickory is tolerant of shade and has a slow growth rate. It reaches a height of 70 to 90 feet and a diameter of 1 to 2 feet. Leaves turn yellow in the fall. The fruit matures in the fall. Shagbark hickory will tolerate a wide variety of growing conditions. The bark, with its shaggy appearance is a good identification feature. It is valued for its timber, and its fruit, although its fruit is much less important today than it was in times past. Shagbark hickory is a true hickory.

1: Photo courtesy of http://commons.wikimedia.org/wiki/File:Hickory_nuts_6060.JPG

2: Image courtesy of http://commons.wikimedia.org/wiki/Category:Carya_ovata 
Shellbark hickory

Carya laciniosa

Juglandaceae

\section{Leaves:}

$15-22$ " long, alternate, pinnately compound with 5-9

leaflets (usually 7), yellowish green in color; hairy

beneath, and on the rachis; deciduous. ${ }^{1}$

\section{Flowers/Fruit:}

Flowers are greenish catkins that appear in the spring; fruit is $1 / 34^{\prime \prime}$ to $2 \frac{1}{2}$ " long, a nut with an orange to chestnut brown husk, edible, sweet seed; matures in the fall.

\section{Flowers/Twigs:}

Stout, orange-brown.

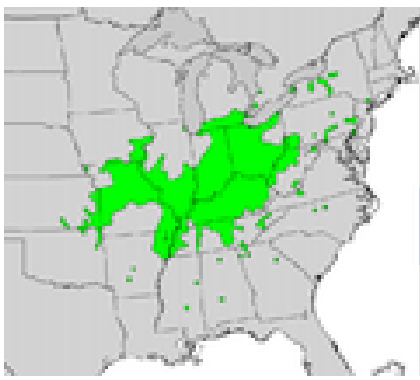

\section{Buds:}

$3 / 4$ " to 1 " long, 6-8 dark brown loosely fitting scales.

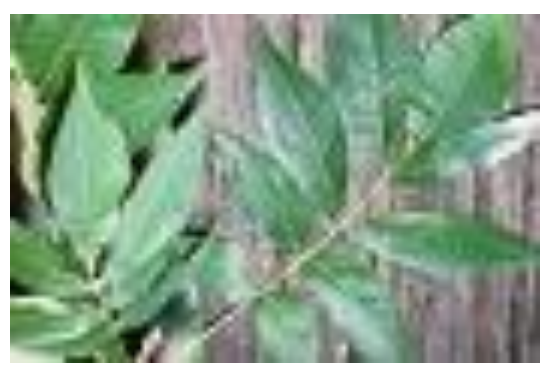

Shellbark hickory is tolerant of shade and has a slow growth rate. It generally reaches a height of 80 to 100 feet and a diameter of 3 to 4 feet. Leaves turn yellowish brown in the fall. Shellbark hickory is similar to Shagbark hickory and the larger sized leaves of Shellbark hickory are a good way to distinguish between these two species. It prefers to grow on moist sites. Shellbark hickory is a member of the true hickories.

1: Photo courtesy of http://commons.wikimedia.org/wiki/Category:Carya_laciniosa 


\section{Mockernut hickory}

\section{Carya tomentosa}

Juglandaceae

\section{Leaves:}

7 to 9 leaflets, alternate, 9-14" long, serrate, pubescent below, pubescent rachis, yellowish green in

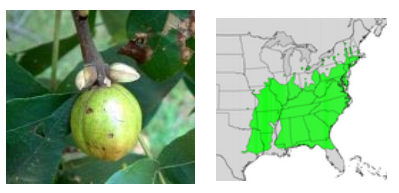
color; deciduous.

\section{Flowers/Fruit:}

Flowers appear in the spring as greenish colored catkins; fruit is $1 \frac{1}{2}-2$ " long, a nut, dark red-brown husk, fragrant, containing an edible seed; matures in the fall.

\section{Flowers/Twigs:}

Stout, very pubescent, and reddish brown.

\section{Buds:}

$1 / 2$ to $3 / 4 "$ long, tomentose, outer scales deciduous.
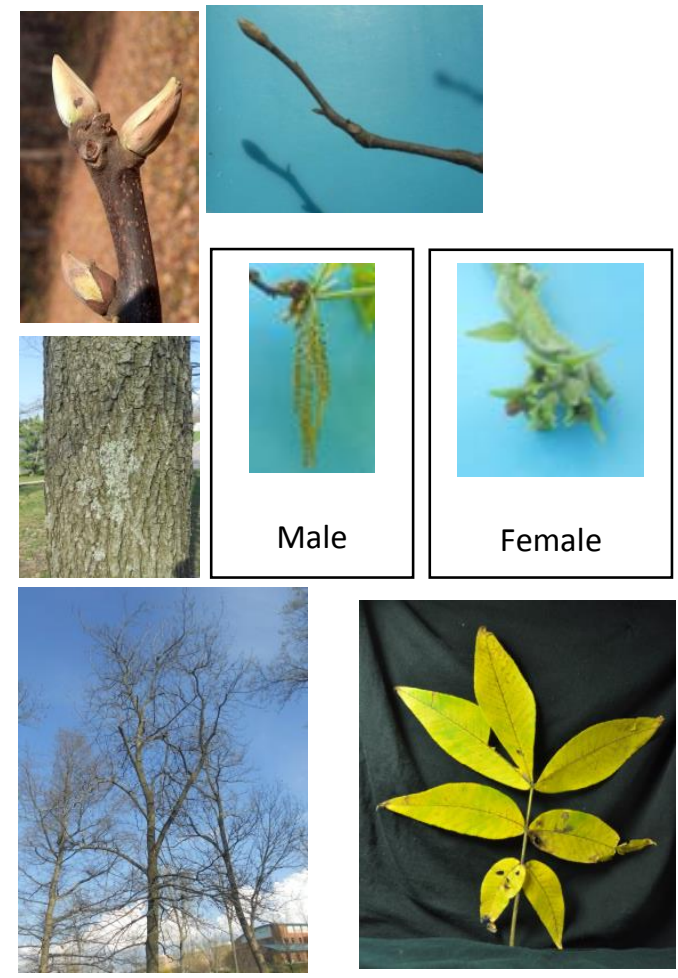

Mockernut hickory is tolerant of shade and has a slow growth rate. It typically grows to a height of 70 to 90 feet and reaches a diameter of 2 feet. Leaves turn yellow in the fall. Mockernut hickory has hard, heavy and strong wood and is used for timber. It is hardy and will tolerate a variety of growing conditions. The tomentose stems and leaves are a good ID feature of this species. It has an oval to rounded crown. Mockernut hickory will tolerate dry sites. Mockernut hickory is a true hickory. 
Pignut hickory

Carya glabra

Juglandaceae

\section{Leaves:}

8 " to 12 "long, pinnately compound with 5 leaflets, dark green, hairless; deciduous.

\section{Flowers/Fruit:}

Flowers appear in greenish catkins in the spring; fruit is 1-2", a nut, slightly pear shaped, greenish brown, husk thin, with an edible seed; matures in the fall.

\section{Twigs:}

Twigs are slender, smooth, and reddish brown.
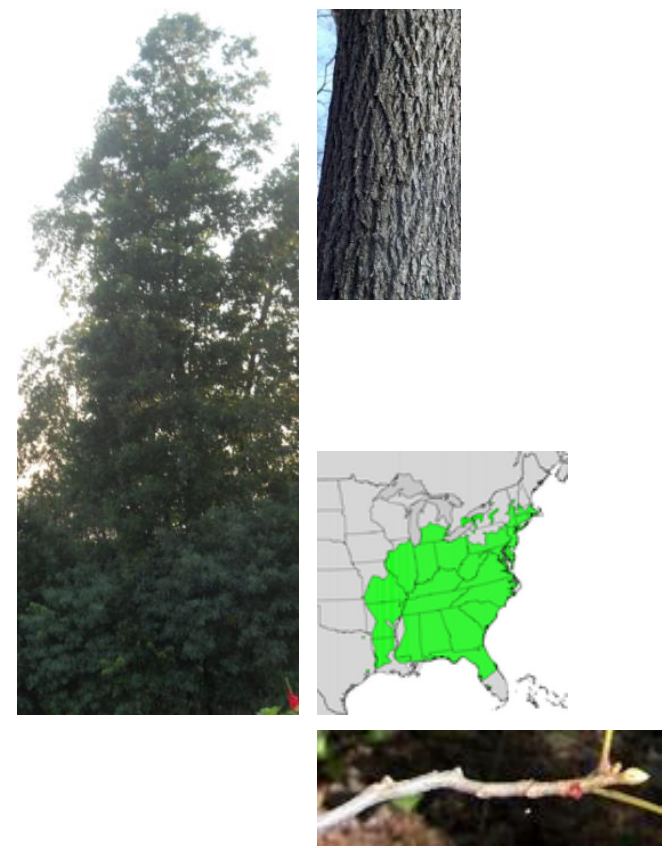

Buds:

To $1 / 4$ " to $1 / 2 "$ long, glabrous, relatively slender.

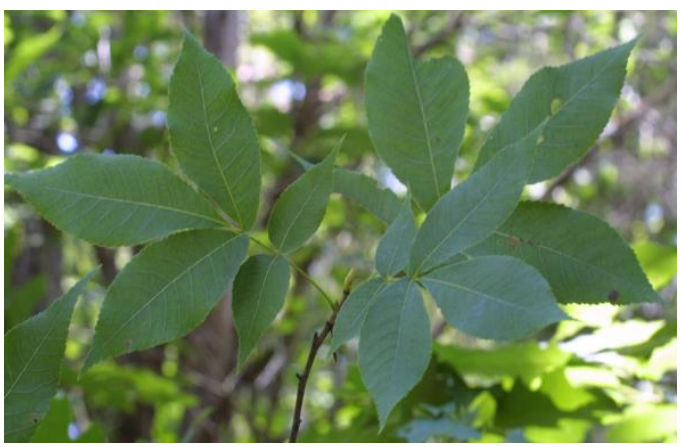

Pignut hickory is tolerant of shade and has a slow growth rate. It reaches a height of 50 to 75 feet and a diameter of 2 to 3 feet. The foliage turns yellow in the fall. The bark is almost smooth. Pignut hickory is used for timber and provides mast for wildlife. It often develops a narrow crown. Pignut hickory is tolerant of dry, upland sites. A good identification feature is the glabrous foliage and stems. Pignut hickory is a true hickory. 


\section{Water hickory}

Carya aquatica

Juglandaceae

\section{Leaves:}

9 " to $15^{\prime \prime}$ long, alternate, pinnately compound with 9 to 17 leaflets, each with serrated margins and a pointed apex; similar to pecan, deciduous. ${ }^{1}$

\section{Flowers/Fruit:}

Flowers appear in the spring as catkins; fruit is 1 " to $1.5^{\prime \prime}$, a nut, dark brown in color, with a four winged husk; seed is bitter, and not edible.

\section{Twigs:}

Somewhat slender, brownish, and lenticellate.

\section{Buds:}

$1 / 4^{\prime \prime}$ to $1 / 2 "$, yellowish brown in color, valvate, and pubescent.
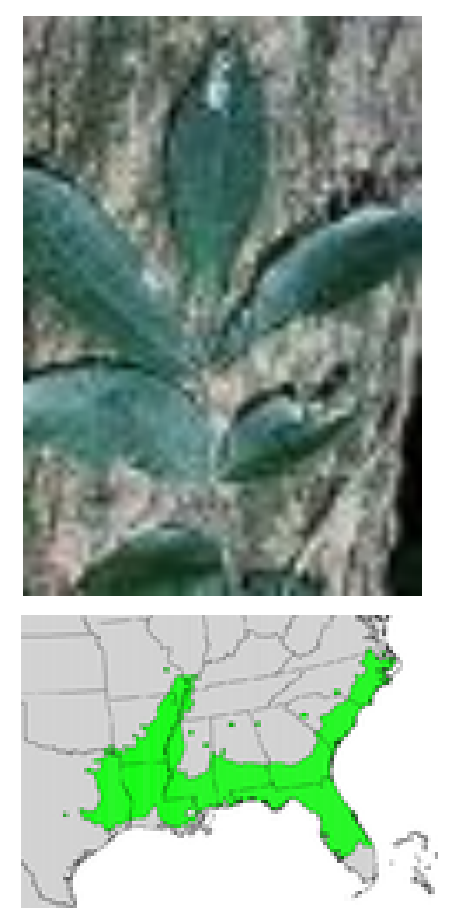

Water hickory is intermediate in shade tolerance and has a slow growth rate. It is similar to pecan. It reaches a height of 70 to 100 feet, and a diameter of 1 to 2 feet. Fall color is yellow. The fruit is conspicuously flattened once the husk splits away. Water hickory grows well in floodplains, and is quite tolerant of flooded sites. It is a member of the pecan hickories.

1: Photo courtesy of http://commons.wikimedia.org/wiki/Category:Carya_aquatica

2: Image Courtesy of http://commons.wikimedia.org/wiki/Category:Carya_aquatica 


\section{Nutmeg hickory}

\section{Carya myristiciformis}

Juglandaceae

\section{Leaves:}

7 to 9 leaflets, $7 \frac{1}{2}$ to $14^{\prime \prime}$ long, alternate, pinnately compound with 7 to 9 leaflets, dark green in color above, lighter green to greyish and hairy beneath; stems hairy; deciduous. ${ }^{1}$

\section{Flowers/Fruit:}

Flowers are greenish and appear in catkins in the spring; fruit is1" to $1.5^{\prime \prime}$, a nut, yellowish brown, four winged, with a thin husk; seed edible. ${ }^{2}$

\section{Twigs:}

Twigs are slender and brown.

\section{Buds:}

To $1 / 5^{\prime \prime}$, valvate scales, yellow brown in color, oval to conical, with small, greyish spots.
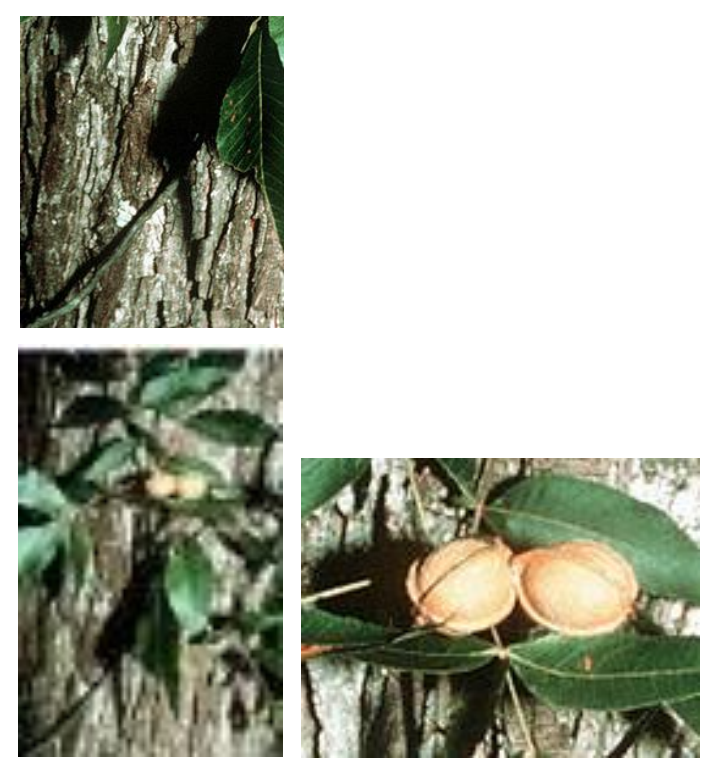

Nutmeg hickory is tolerant of shade in the seedling and sapling stage, but mature trees are intolerant of shade. Its growth rate may be slow, but is somewhat unknown due to lack of study. Its leaves turn yellow in the fall. The fruit matures in the fall. Nutmeg hickory occurs in mostly scattered populations throughout its range. It prefers moist soils. Nutmeg hickory is a member of the pecan hickory group. 
American beech

Fagus grandifolia

Fagaceae

\section{Leaves:}

$2 \frac{1}{2-6 "}$ long, alternate; elliptical; dark green, simple and sparsely-toothed; deciduous, turning yellow and brown in the fall.

\section{Flowers/Fruit:}

Flowers are greenish and monoecious; fruit is $1 / 2-3 / 4 "$ long, edible, a sharply-angled nut, with a threewinged, prickly husk.

\section{Twigs:}

Slender, narrow stipule scars encircling the twig.

\section{Buds:}

$3 / 4^{\prime \prime}-1 "$ long, slender, lance-shaped, brown, very sharp
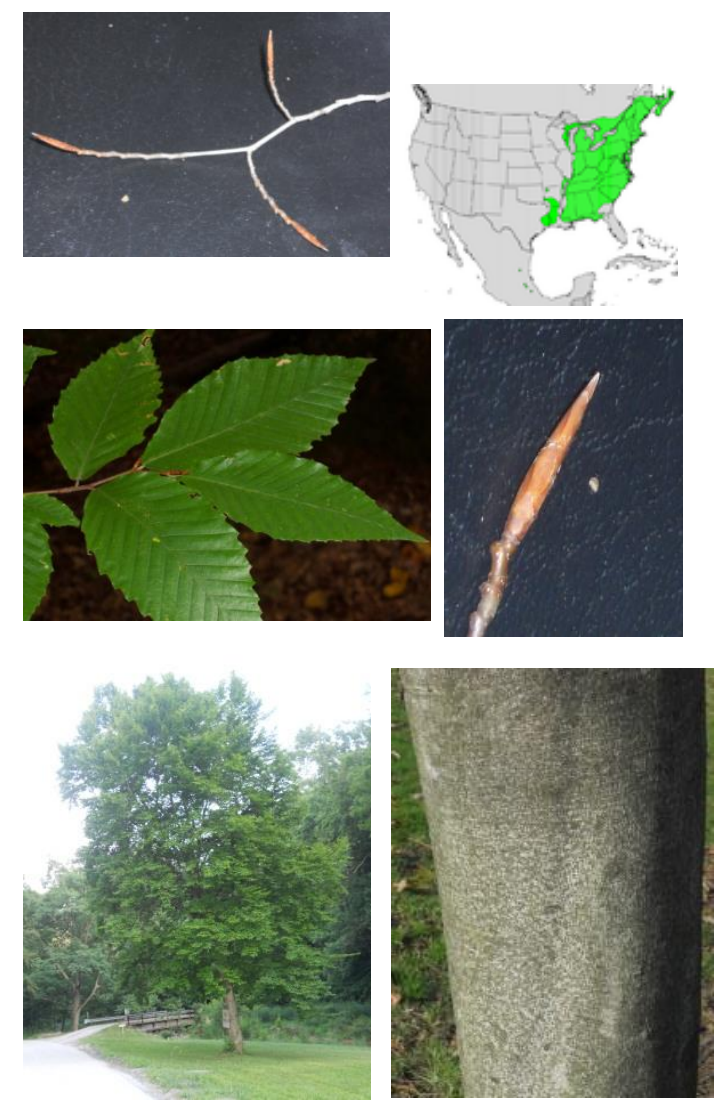

American beech is tolerant of shade, and has a slow to sometimes moderate growth rate. It reaches a height of 60 to 100 feet and a diameter of 2 to 3 feet. Leaves often persist into winter, especially towards the inner parts of the crown. These leaves are dead, and are typically a light brown in color. American beech generally grows on moist, undisturbed sites. Winter twigs have two rows of overlapping scales on the buds. American beech often develops large cavities with age due to its susceptibility to rot. 


\section{American chestnut}

\section{Castanea dentata}

Fagaceae

\section{Leaves:}

$51 / 2-8$, alternate, dark green; oblong-lanceolate, coarsely and sharply serrate, with bristle-tipped teeth, glabrous, deciduous.

\section{Flowers/Fruit:}

Flowers are monoecious, cream colored and appear in catkins (staminate) in late spring -early summer; fruit is $2-2 \frac{1}{2}$ " long, brown, husk covered with branched spines; each fruit contains 2 to three edible seeds.

\section{Twigs:}

Olive green to chestnut brown, glabrous.

\section{Buds:}

$1 / 4 "$, ovoid, brown 2-3 visible scales.
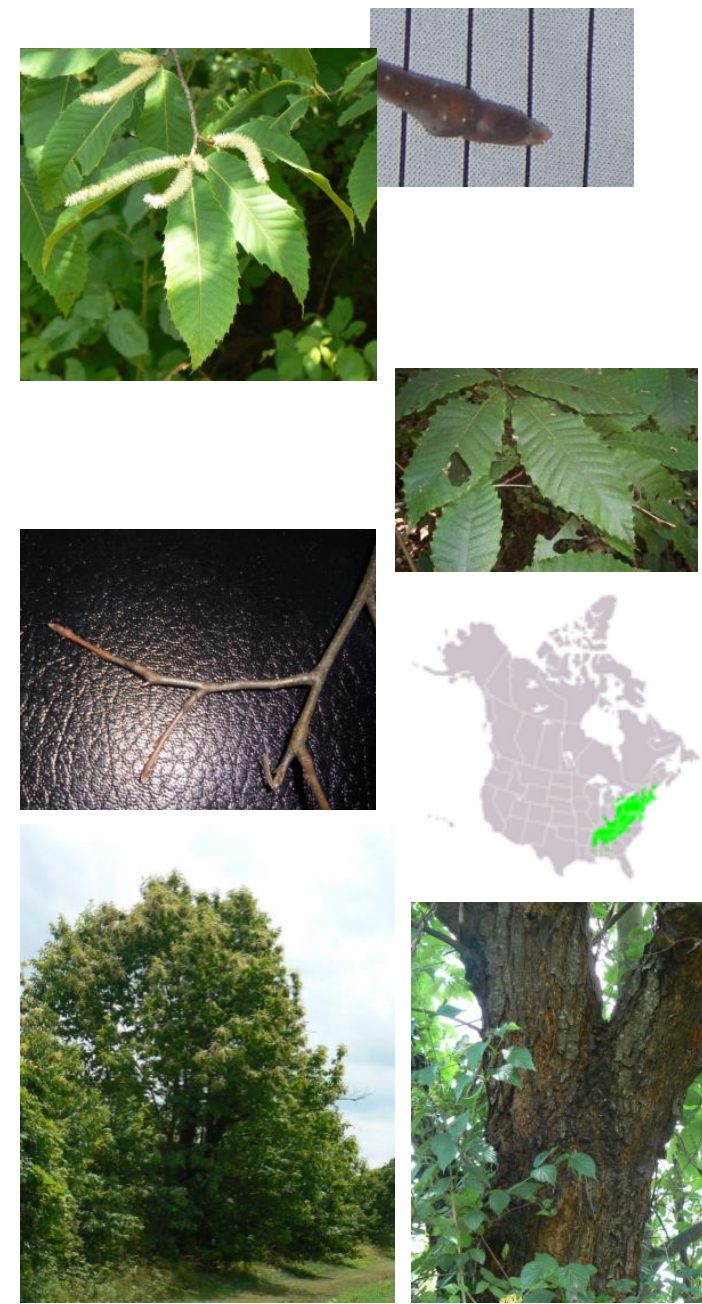

American chestnut is intermediate in shade-tolerance and has a rapid growth rate. It once grew to a height of 120 feet and reached a diameter of up to 4 feet. However, currently, American chestnut rarely attains a height of more than 30 feet and a diameter greater than 8 " to 10 " due to the chestnut blight (Cryphonectria parasitica) which has reduced American chestnut to stump sprouts throughout its native range. Leaves turn yellow to brown in the fall. Twigs are lenticellate. Nuts make delicious and nutritious food. 
Tanoak

Lithocarpus densiflorus

Fagaceae

\section{Leaves:}

2.8-5.9" long, alternate, dark green on upper surface, greyish and pubescent below, oblong, repand-dentate to entire; leathery and evergreen. ${ }^{1}$

\section{Flowers/Fruit:}

Flowers are monoecious; fruit is $0.8^{\prime \prime}$ long, a bitter acorn with a shallow cap covered with hairy scales; brown in color. ${ }^{2}$

\section{Twigs:}

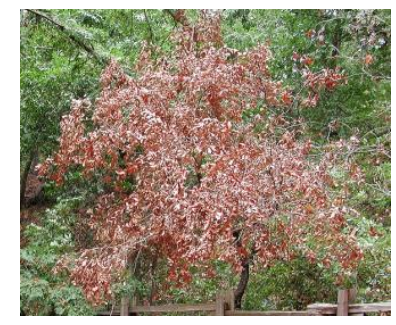

4

Pubescent, becoming reddish brown. ${ }^{3}$

\section{Buds:}

Greyish brown, in clusters at ends of twigs.
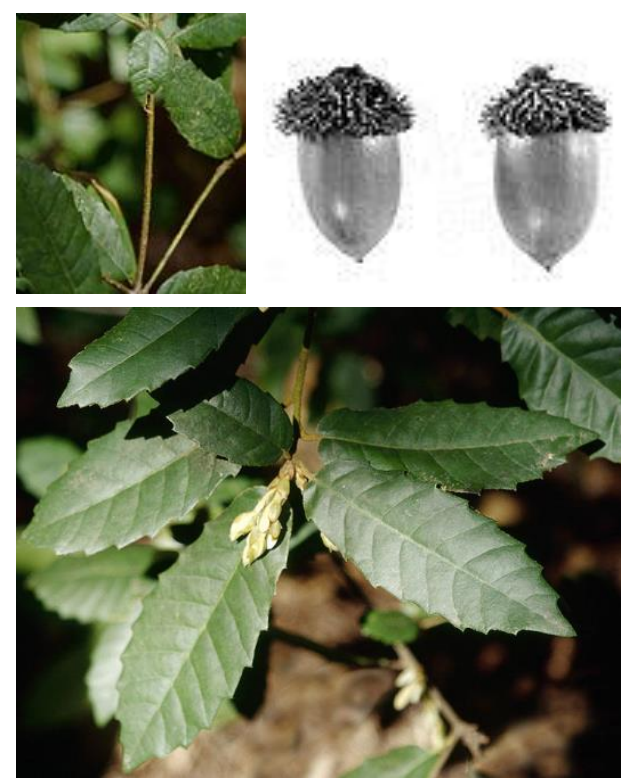

Tanoak is tolerant of shade and has a moderate growth rate. It reaches a height of 60 to 100 feet and a diameter of 1 to 3 feet. The name refers to its tannin-rich bark used for tanning leather. The staminate flowers are cream colored, appear in catkins, and are similar to those of American chestnut. The twigs are glaucous. Tanoak generally has a pyramidal crown shape. Acorns mature in 2 years. 
White oak

\section{Quercus alba}

Fagaceae

\section{Leaves:}

5-9" long, alternate, very dark green above, paler below; oblong-obovate, 7-9 rounded lobes, margins of lobes entire, deciduous.

\section{Flowers/Fruit:}

Flowers are monoecious and greenish brown (staminate in catkins); fruit is $1 / 2-3 / 4$ " long, an acorn, cap with bumpy scales covers $1 / 4$ length of acorn; chestnut brown in color.

\section{Twigs:}

Moderately stout, purplish grey to greenish red.

\section{Buds:}

$1 / 8^{\prime \prime}$ long, globose to ovoid, reddish brown, clustered.
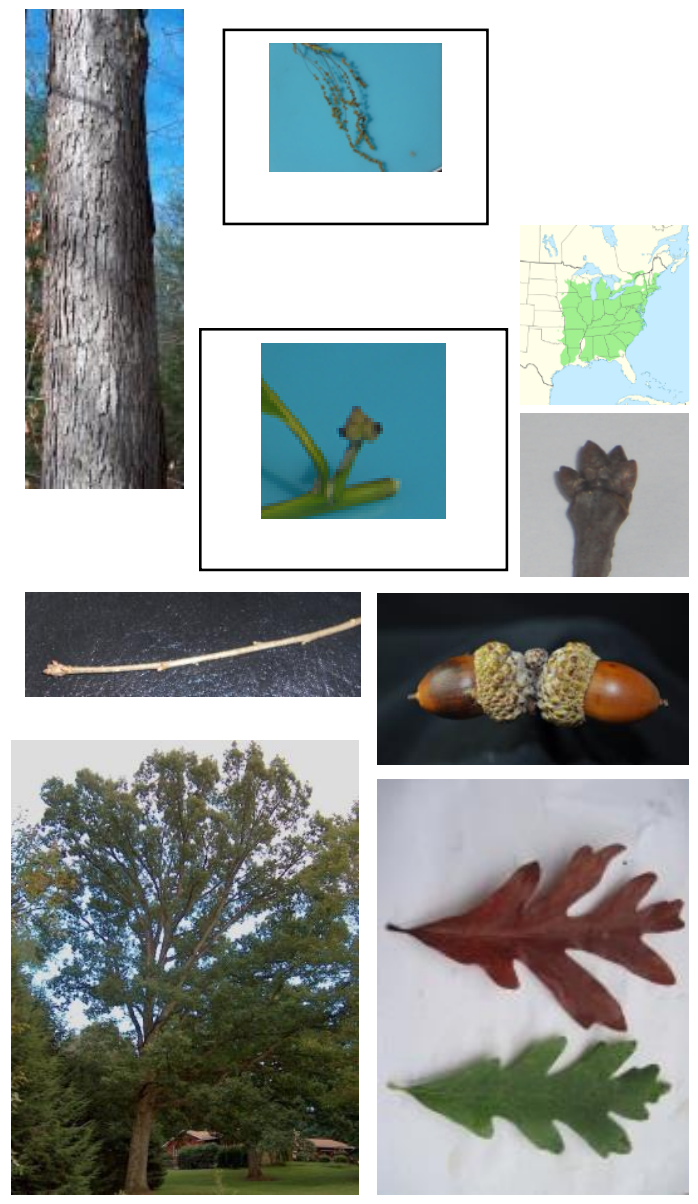

White oak is intermediate in shade-tolerance and has a slow growth rate. It generally reaches a height of 80 to 100 feet and a diameter of 3 to 4 feet. It is used for timber which is important for barrel making, furniture, and many other purposes. White oak has a long life span of up to 600 years. Like other members of the white oak group, acorns mature in one year, and tyloses are present in the wood. The leaves turn brown to red, to even wine-colored in the fall. Foliage is often marcescent. 
Bur oak

Quercus macrocarpa

Fagaceae

\section{Leaves:}

6-12", alternate, dark green, obovate to oblong, 5-9 lobed with upper lobes larger than lower, pubescent on lower side; deciduous.

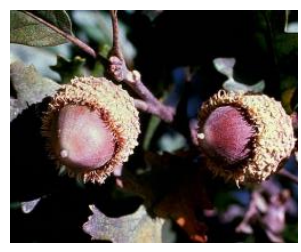

\section{Flowers/Fruit:}

Flowers are monoecious, and greenish brown (staminate in catkins); fruit is $3 / 4-1 \frac{1}{2}$ " long, an acorn, broadly ovoid, downy at apex, fringed cap covers $1 / 2$ of acorn, brown.

\section{Twigs:}

Twigs are stout, yellowish brown, pubescent.

\section{Buds:}

$1 / 4^{\prime \prime}$ to $1 / 8^{\prime \prime}$ long, greyish yellow, obtuse, tawny pubescent.
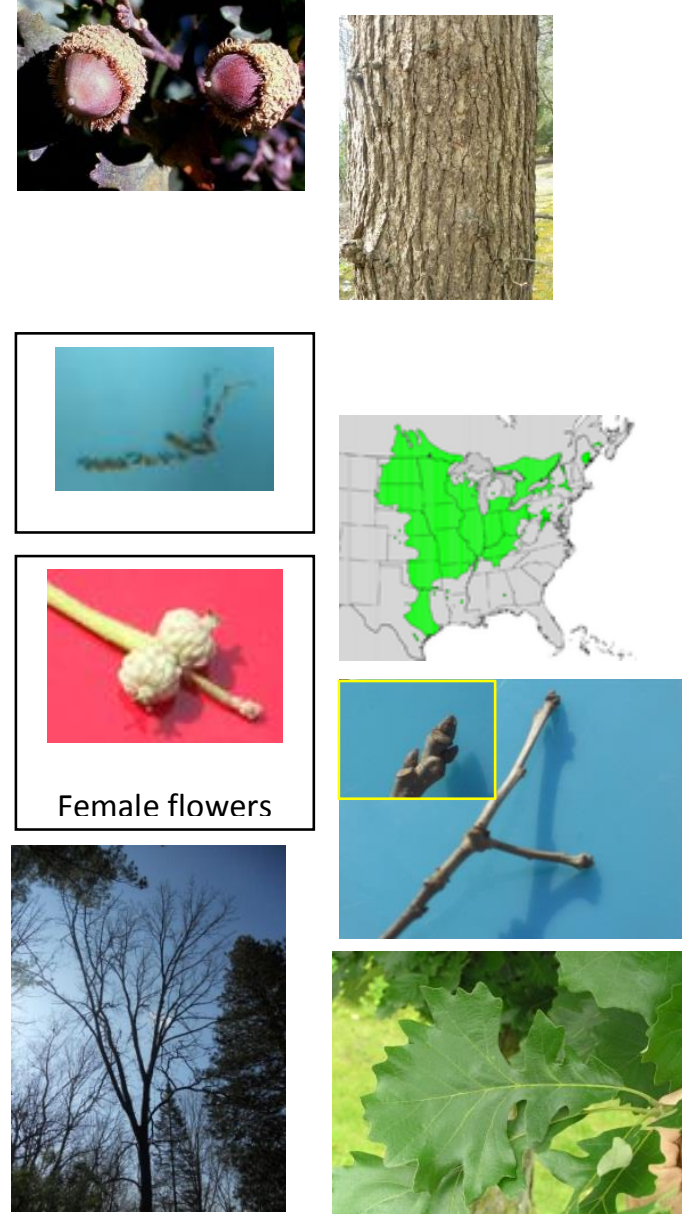

Bur oak is intermediate in shade-tolerance and has a slow growth rate. It reaches a height of 70 to 80 feet and a diameter of 3 to 4 feet. Leaves turn brown to yellow in the fall. Twigs sometimes have corky wings present. Bur oak will tolerate a variety of growing conditions, but prefers to grow on bottomland sites. Although the bark of Bur oak is similar to that of White oak, it is generally darker in color. Bur oak is used for timber. Bur oak is a member of the white oak group. 
Post oak

\section{Quercus stellata}

\section{Fagaceae}

\section{Leaves:}

Thick, 4-6", alternate, oblong, dark green, deeply 5 lobed, cruciform appearance, hairy beneath; deciduous.

\section{Flowers/Fruit:}

Flowers are monoecious, greenish brown (staminate in catkins); fruits is $1 / 2$ " to $2 / 3^{\prime \prime}$ long, an acorn, brown, slightly striped, $1 / 3$ of acorn enclosed in cap, scales hairy.

\section{Twigs:}

Tawny, tomentose, grey and lenticellate.

\section{Buds:}

$1 / 8^{\prime \prime}$ long, with chestnut brown pubescent scales.
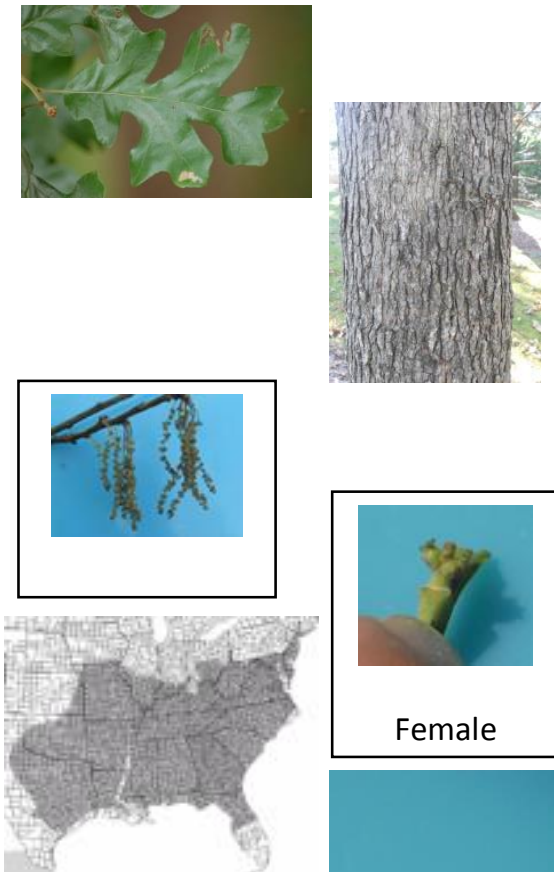

Female
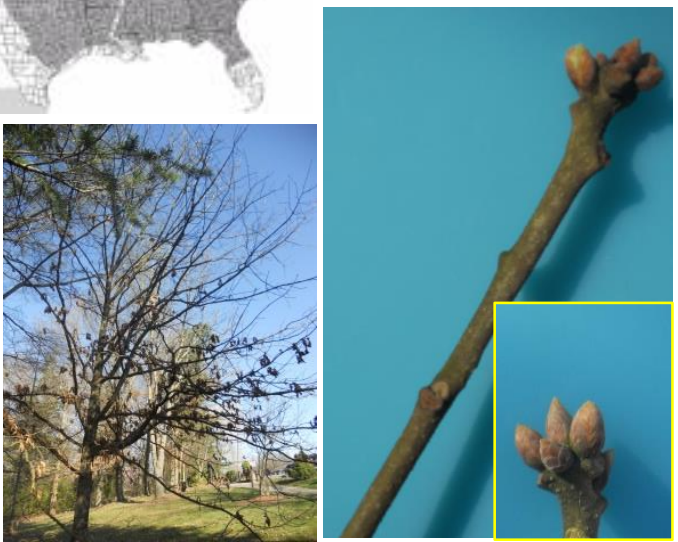

Post oak is intermediate in shade-tolerance and has a slow growth rate. It reaches a height of 50 to 80 feet and a diameter of 1 to 2 feet. The leaves turn yellow to brown in the fall. Post oak will tolerate a variety of growing conditions and frequently grows on dry sites. It generally develops an irregular crown of contorted branches. The cruciform appearance of the leaves is an excellent identification feature. Post oak is a member of the white oak group. 


\section{Chestnut oak}

\section{Quercus prinus}

Fagaceae

\section{Leaves:}

4-8" long, alternate, shiny dark green obovate to elliptical, crenate margin, yellow stem; deciduous.
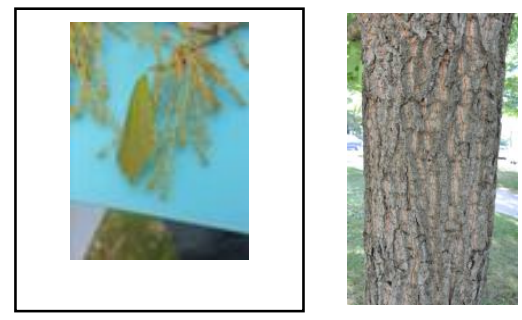

\section{Flowers/Fruit:}

Flowers are monoceious, yellowish brown; fruit is $1-1$ $1 / 2$ ", an acorn, dark brown, ovoid, $1 / 3$ to $1 / 2$ " of length covered by a thin cap with bumpy scales.

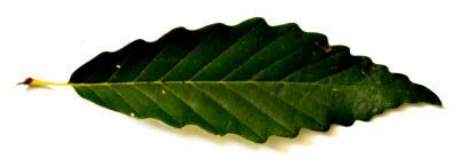

\section{Twigs:}

Twigs are orange to reddish brown, glabrous.
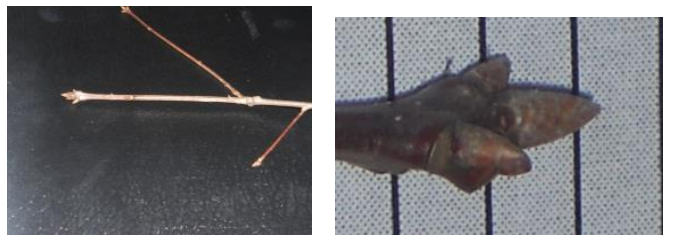

\section{Buds:}

$1 / 4$ " long, covered with bright chestnut brown scales.
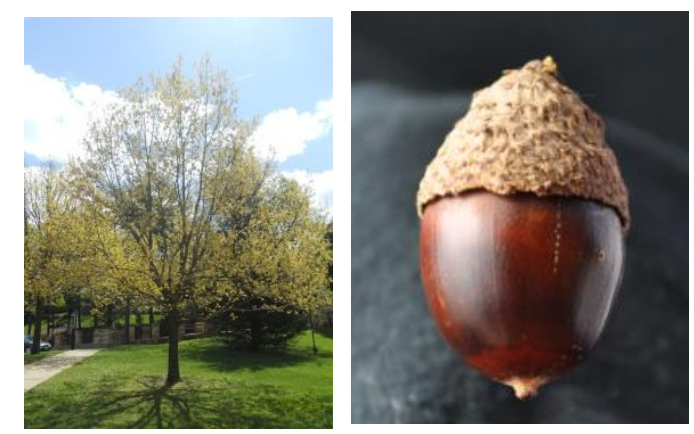

Chestnut oak is intermediate in shade-tolerance and has a slow growth rate. It reaches a height of 50 to 80 feet and a diameter of 1 to 2 feet. The leaves turn yellow to brown in the fall. Staminate flowers appear in catkins. Mature Chestnut oaks can easily be identified by the conspicuous ridges and furrows of the bark. The wood of Chestnut oak is used for timber. It grows on a variety of sites, but is typically found on dry ridges, and dry, rocky sites. Chestnut oak is a member of the white oak group. 
Swamp chestnut oak

Quercus michauxii

Fagaceae

\section{Leaves:}

5-8" long, alternate, dark green on upper surface, paler beneath, obovate-oblong, dentate, pubescent below, deciduous.

\section{Flowers/Fruit:}

Flowers are monoecious; fruit is $1-1 \frac{1}{2}$ " long, an acorn, ovoid to oblong, less than $1 / 3$ enclosed in a bowl-shaped cap with hairy, wedge-shaped scales.
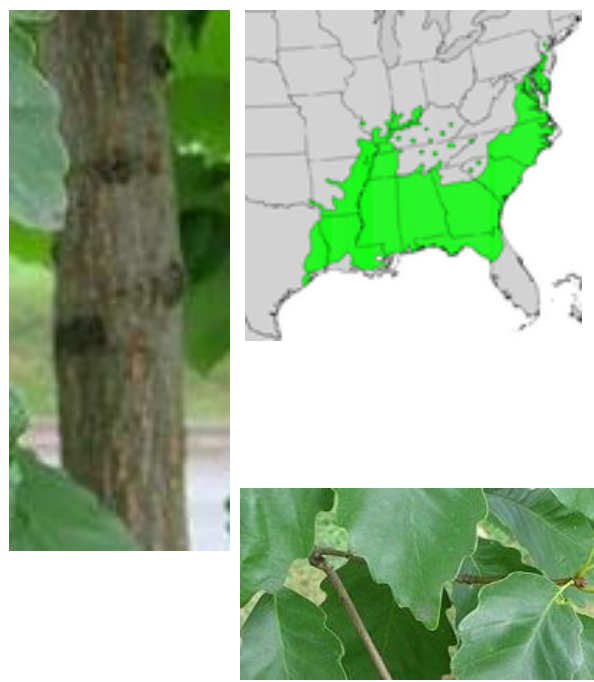

\section{Twigs:}

Moderately stout, reddish brown to orange brown. ${ }^{1}$

\section{Buds:}

$1 / 4$ " long, acute, covered with thin red scales.

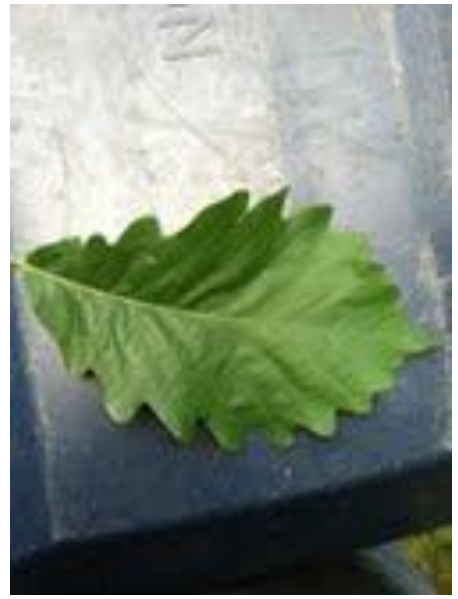

Swamp chestnut oak has intermediate shade-tolerance and a slow growth rate. It generally reaches a height of 60 to 80 feet and a diameter of 2 to 3 feet. Its flowers are greenish to yellow brown, with the staminate flowers appearing in catkins. The leaves turn red to brown in the fall. The bark is ash grey, with some red coloration. Swamp chestnut oak grows on bottomlands and moist uplands. The wood is hard, strong, and used for timber. Swamp chestnut oak is a member of the white oak group. 
Chinkapin oak

\section{Quercus muehlenbergii}

Fagaceae

\section{Leaves:}

$4 "$ to 7" long, alternate, shiny green above, paler and pubescent beneath, obovate to oblong, coarsely serrate, deciduous.

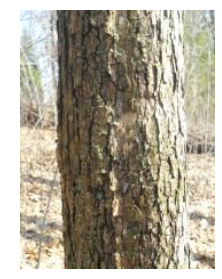

\section{Flowers/Fruit:}

Flowers are monoecious; fruit is $1 / 2$ " long, brown to black, an acorn with a thin bowl-shaped cap which encloses $1 / 3$ of the nut, and is covered with appressed scales.

\section{Twigs:}

Twigs are slender, orange-brown, and glabrous.

\section{Buds:}

$1 / 8$ " long, orange brown, sharp pointed.
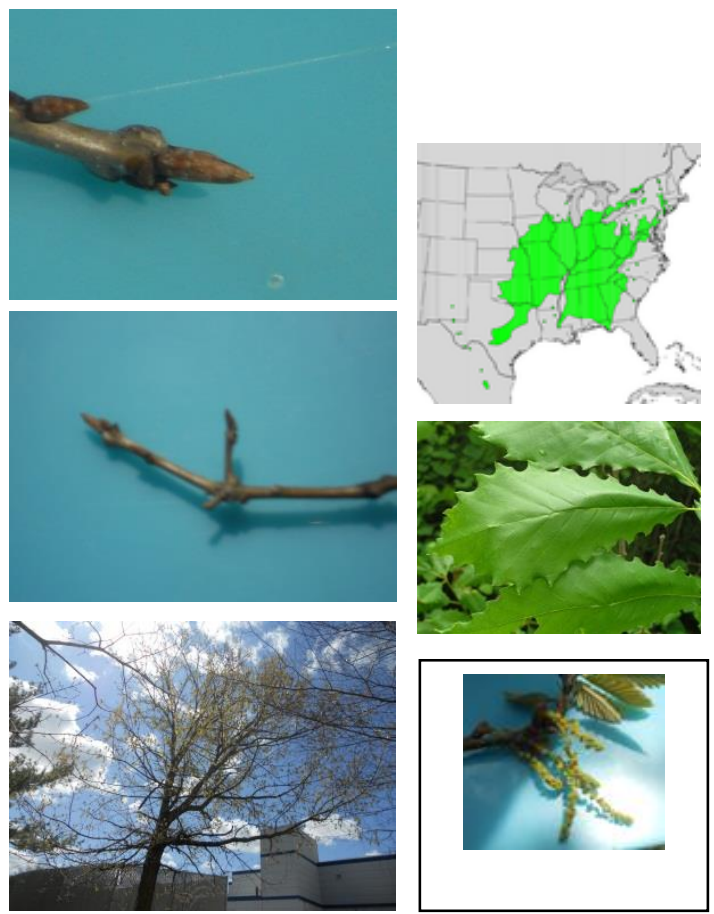

Chinkapin oak has intermediate shade-tolerance and a slow growth rate. It typically reaches a height of 50 to 80 feet and a diameter of 1 to 3 feet. Leaves turn red to brown in the fall. The flowers are green to yellow-brown and staminate flowers appear in catkins. Chinkapin oak prefers to grow on dry slopes and outcrops. Teeth of leaves are gland tipped. With age, Chinkapin oak develops an irregular crown. Chinkapin oak is a member of the white oak group. 
Valley oak

Quercus lobata

Fagaceae

\section{Leaves:}

3" long, oblong to ovate, 7-11 deep lobes, finely pubescent, deciduous. ${ }^{1}$

\section{Flowers/Fruit:}

Flowers are monoecious ${ }^{2}$; fruit is $1-2 \frac{1 / 4}{\prime \prime}$ long, an acorn, green at first turning brown, elongated-conic, 1/3 enclosed in a fringed cap.

\section{Twigs:}

Twigs are slender, pubescent, grey. ${ }^{3}$

\section{Buds:}

To $1 / 5^{\prime \prime}$, light brown, pubescent, oval.
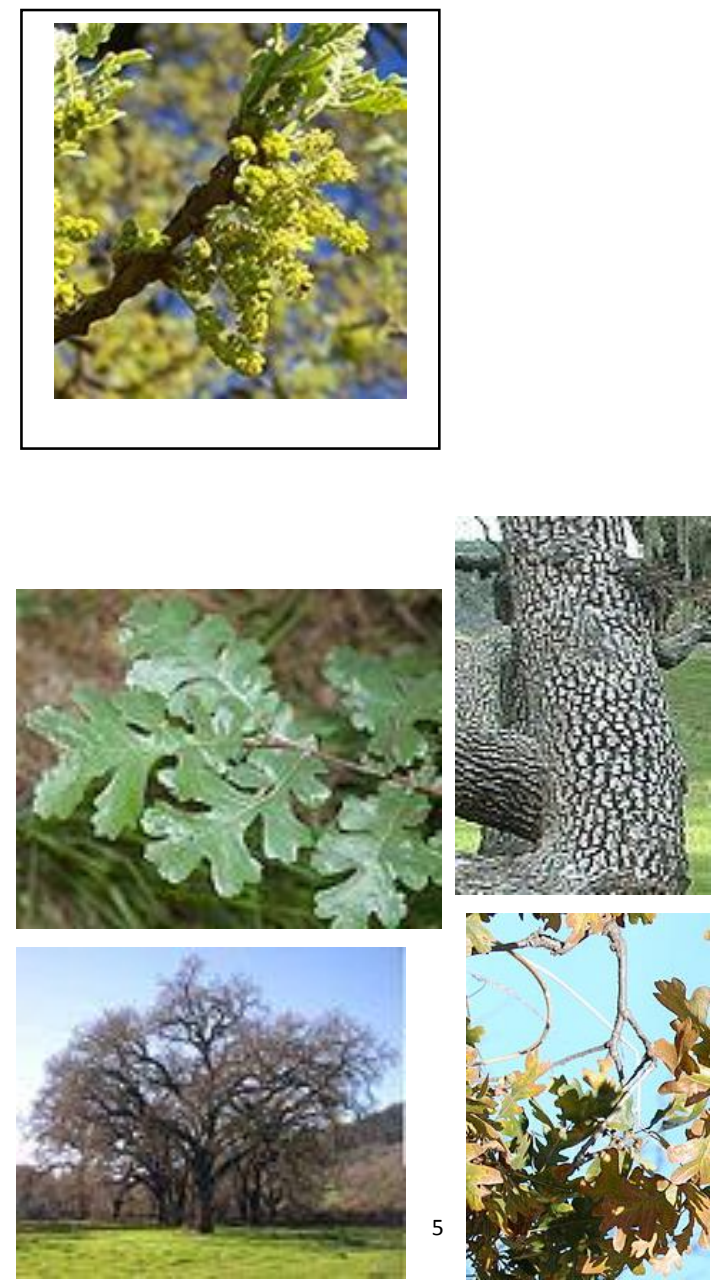

Valley oak has intermediate shade-tolerance and a moderately rapid growth rate. I eaches a height of 80 to 120 feet and a diameter of 3 to 5 feet. It generally has a wide spreading crown and a short trunk. It is also called California white oak. The leaves turn yellow in the fall. Valley oak is very long lived and typically grows in hot valleys and foothills throughout its native range. Valley oak is a member of the white oak group.

\footnotetext{
1: Photo courtesy of http://commons.wikimedia.org/wiki/Category:Quercus_lobata

2: Photo courtesy of http://commons.wikimedia.org/wiki/File:Quercus_lobata-2.jpg

3: Photo courtesy of http://commons.wikimedia.org/wiki/File:Quercus_lobata-9.jpg

4: Photo courtesy of http://commons.wikimedia.org/wiki/File:Lopez_Lake_Tree.jpg 
Northern red oak

Quercus rubra

Fagaceae

\section{Leaves:}

5-8" long, alternate, dark green, oblong, 7 - 11 toothed lobes, separated by sinuses extending midway to mid rib, lobes bristle tipped, deciduous.

\section{Flowers/Fruit:}

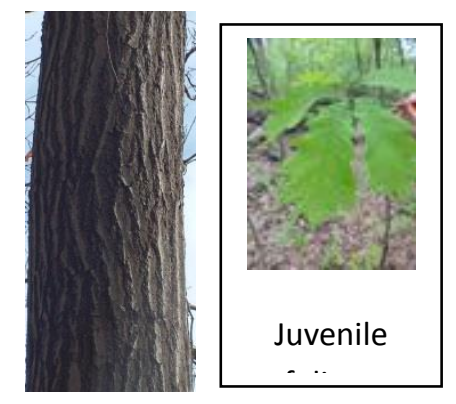

Flowers are monoecious; fruit is $3 / 4 " 1$ " 1 , an acorn, brown, subglobose, somewhat hairy, enclosed $1 / 4$ of way by shiny, shallow cap.

\section{Twigs:}

Twigs are glabrous, reddish brown.

\section{Buds:}

$1 / 4^{\prime \prime}$ long, ovoid, with reddish brown smooth scales.
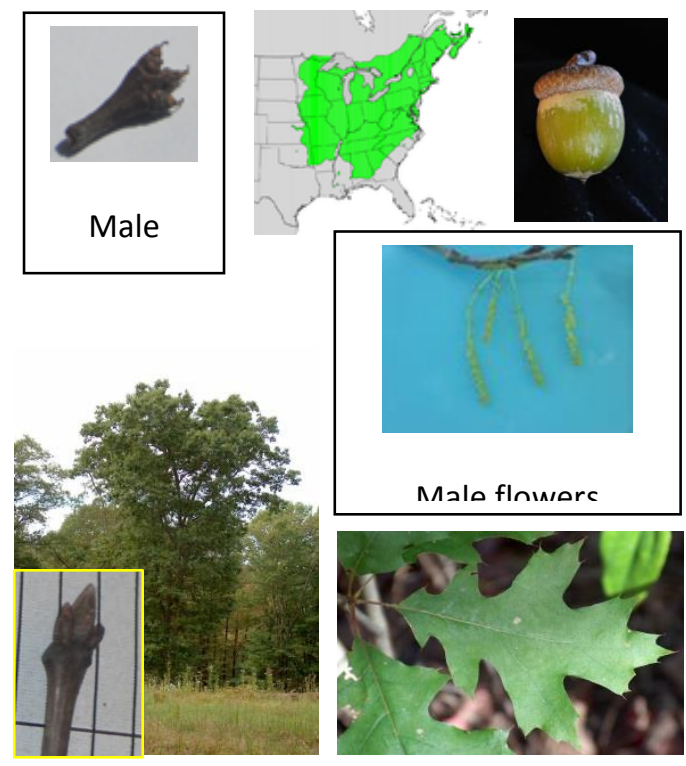

Northern red oak has intermediate shade-tolerance and a rapid growth rate. It reaches a height of 60 to 90 feet and a diameter of 1 to 3 feet. Flowers appear in the spring, with the staminate flowers in yellowish brown catkins. The leaves turn yellow to red, to brown in the fall. The pattern of alternating dark brown and lighter grey coloring of the bark gives the appearance of vertical stripes on the trunks of older trees. Northern red oak is a very important timber species. Northern red oak is a member of the red oak group. 
Black oak

Quercus velutina

Fagaceae

\section{Leaves:}

5-7", alternate, dark green and shiny above, paler, greyish and pubescent below, obovate to ovate, 5-7 toothed lobes, separated by sinuses of varying depth, lobes bristle tipped; deciduous.

\section{Flowers/Fruit:}

Flowers are monoecious; fruit is $1 / 2-3 / 4$ " long, an acorn, brown, ovoid, striate, enclosed $1 / 4$ of way by brown cap with hairy scales.

\section{Twigs:}

Twigs are stout, reddish brown, glabrous.

\section{Buds:}

$1 / 4-1 / 2^{\prime \prime}$ long, sharp-pointed, tan, tomentose.

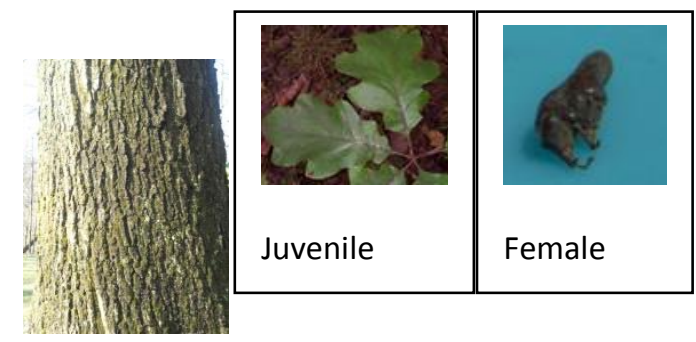

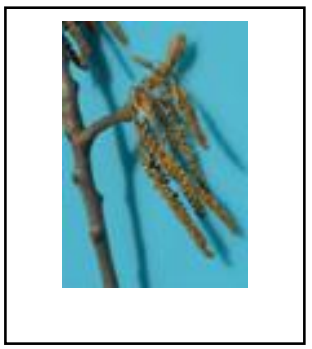
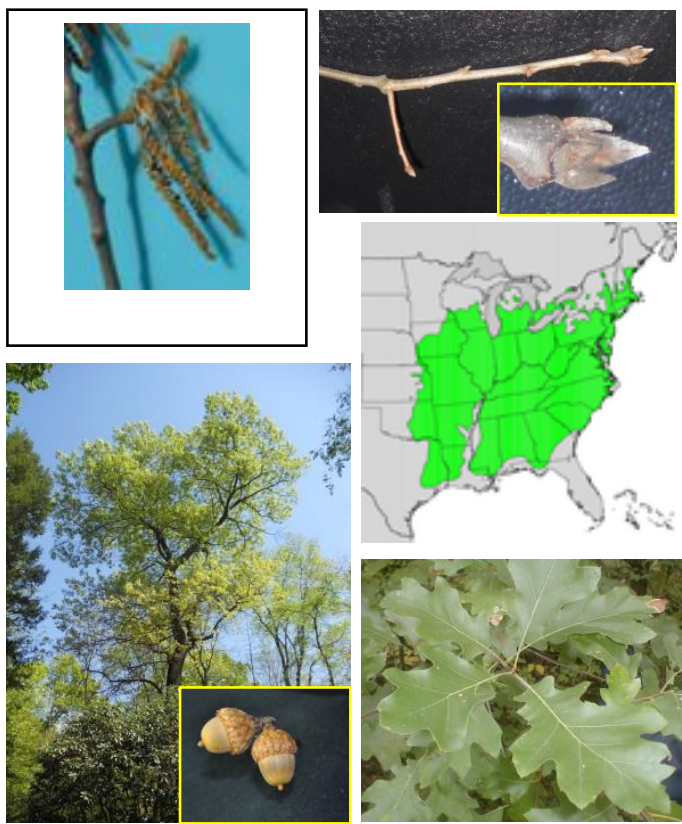

Black oak has intermediate shade-tolerance and a rapid growth rate. It generally reaches a height of 50 to 70 feet and a diameter of 1 to 3 feet. The leaves turn yellow to brown (sometimes orangish red) in the fall. The staminate flowers are a yellowish brown color and appear in catkins. The deep furrows in the bark are intersected by horizontal fissures, giving the bark a blocky appearance. Black oak is used for timber, sold as red oak. Black oak is tolerant of a variety of growing conditions. Black pak is a member of the red oak group. 
Shumard oak

\section{Quercus shumardii}

Fagaceae

\section{Leaves:}

6-8" long, alternate, obovate to oval, 7-9 toothed lobes, dark green, separated by moderately deep sinuses, lobes bristle tipped, deciduous. ${ }^{1}$

\section{Flowers/Fruits:}

Flowers are monoecious; fruit is $3 / 4-11 / 4$ " long, an acorn, ovoid, covered with a thick, shallow, saucershaped cap.

\section{Twigs:}

Moderately stout, gray to gray-brown, glabrous.

\section{Buds:}

$1 / 4$ " long, ovoid, sharp pointed, angles, gray to graybrown scales.
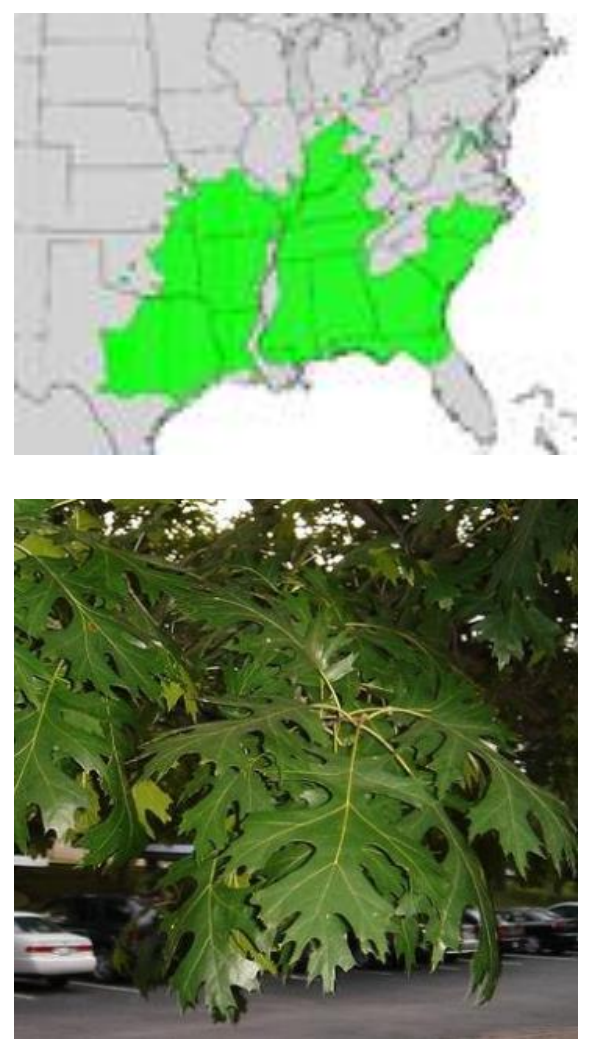

Shumard oak is intolerant of shade and has a rapid growth rate. It generally reaches a height of 70 to 90 feet and a diameter of 2 to 5 feet. The leaves turn red to brown in the fall. The flowers are yellowish brown in color, with staminate flowers appearing in catkins. Shumard oak is one of the largest southern red oaks and is used for timber. It will grow on a variety of sites. It generally has a pyramidal crown when young, but becomes broad and spreading with age. Shumard oak is a member of the red oak group.

1: Photo courtesy of http://commons.wikimedia.org/wiki/File:Shumard_oak_leaves.JPG

2: Image courtesy of http://commons.wikimedia.org/wiki/Category:Quercus_shumardii 
Southern red oak

\section{Quercus falcata}

Fagaceae

\section{Leaves:}

5-9" long, alternate, obovate, shallowly 3-lobed or deeply 5-7 lobed, falcate, tomentose underside; deciduous.

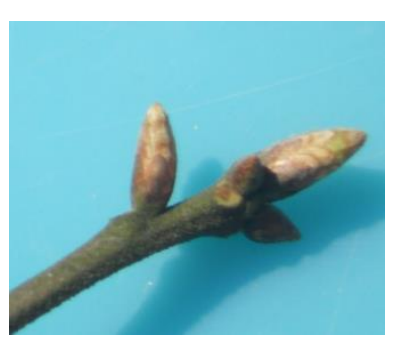

\section{Flowers/Fruits:}

Flowers are monoecious; fruit is $1 / 2$ " long, subglobose, an acorn, orange-brown, enclosed less than $1 / 3$ by shallow, pubescent cap. ${ }^{1}$

\section{Twigs:}

Twigs are dark red, glabrous or pubescent.

\section{Buds:}

1/8-1/4" long, reddish brown, sharp pointed, pubescent.
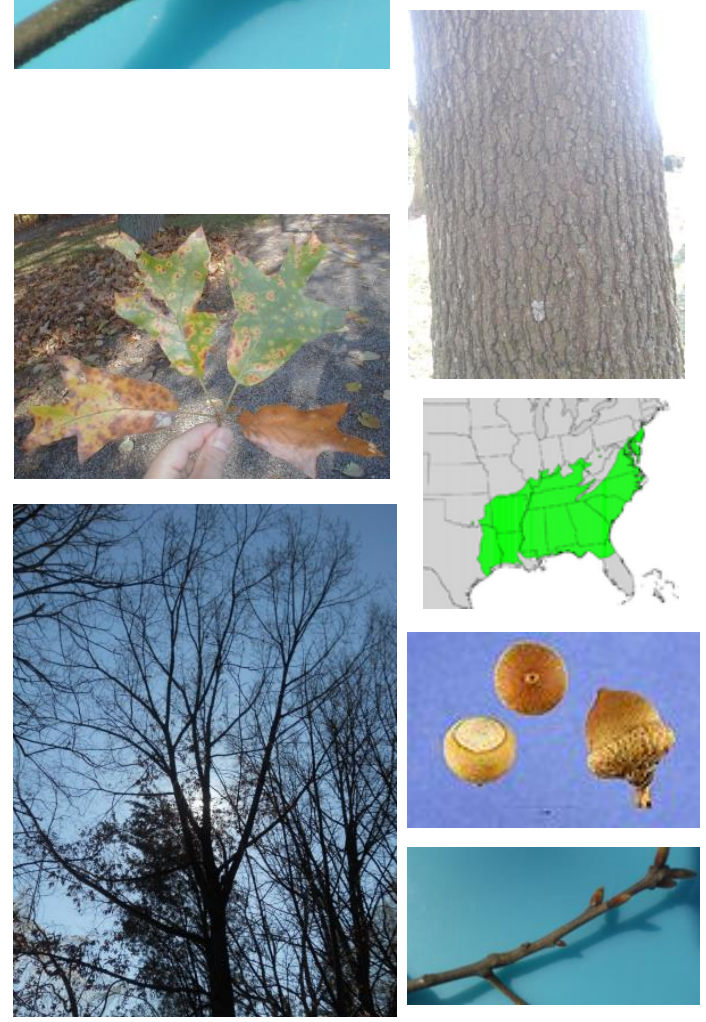

Southern red oak is intolerant of shade and has a rapid growth rate. It reaches a height of 90 to 100 feet and a diameter of 1 to 3 feet. The leaves are dark green above, paler beneath, and turn brownish in the fall. Foliage is typically marcescent. The flowers are brownish in color, with staminate flowers appearing in catkins. Inner bark is cream colored. Southern red oak prefers poor, dry sites. Its wood is used for timber. It develops a wide spreading, round crown. Southern red oak is a member of the red oak group. 
Scarlet oak

Quercus coccinea

Fagaceae

\section{Leaves:}

4-7" long, alternate, dark green, shiny, 5 to 9 lobed with wide, deep, C-shaped, circular sinuses; lobes bristle tipped; deciduous.

\section{Flowers/Fruit:}

Flowers are monoecious; fruit is $1 / 2-1$ " long, oval, an acorn, reddish brown, $1 / 2$ enclosed in bowl-like cap with thick, smooth, scales, circular grooves at apex.

\section{Twigs:}

Twigs are slender, reddish brown, and smooth.

Buds:

$1 / 8-1 / 4$ " long, covered with reddish brown scales.
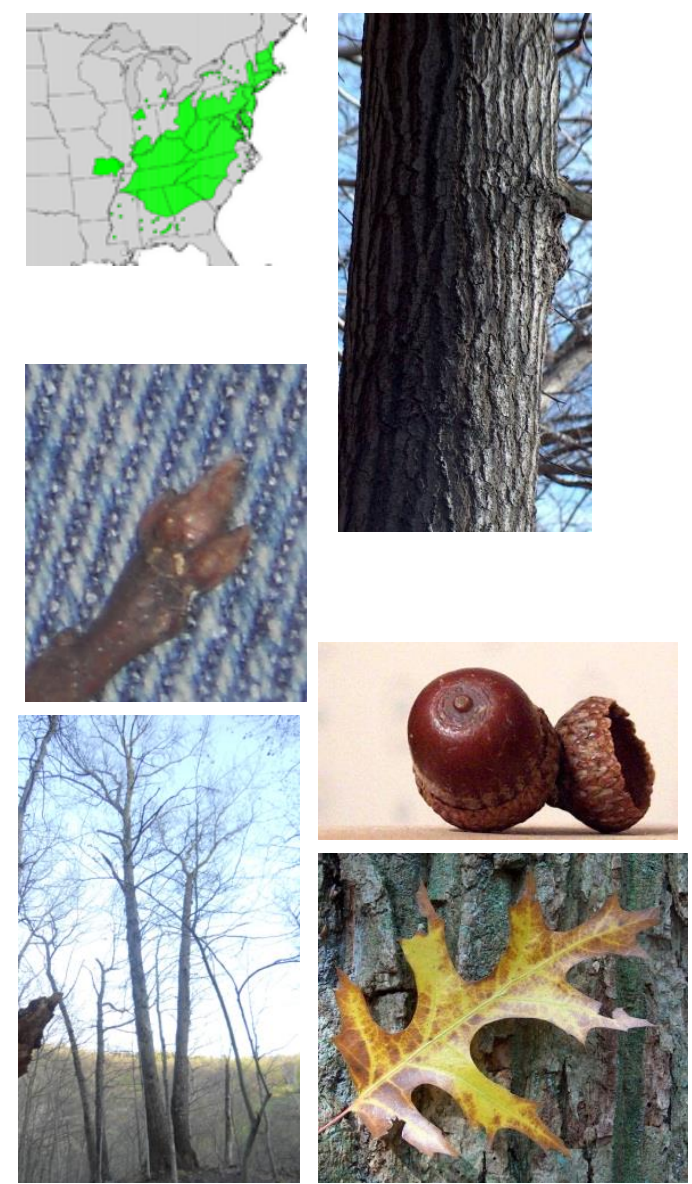

Scarlet oak is intolerant of shade and has a rapid growth rate. It grows to a height of 50 to 75 feet and a diameter of 1 to 3 feet. Flowers are yellowish brown and appear in the spring (staminate flowers appear in catkins). Leaves turn red in the fall, and foliage is often marcescent. Buds are often pubescent at the ends. Scarlet oak develops an irregular to rounded crown and typically retains dead branches along its bole and in the lower portions of its crown. Scarlet oak is a member of the red oak group. 
Pin oak

\section{Quercus palustris}

Fagaceae

\section{Leaves:}

3-5" long, alternate, dark green, shiny, obovate to oval, usually 5 lobed with deep sinuses, bristle-tipped; deciduous, turning red to brown in the fall.

\section{Flowers/Fruit:}

Flowers are monoecious; fruit is $1 / 2$ " long, an acorn, brown, hemispherical, pale brown, striate, enclosed in thin saucer like cap.

\section{Twigs:}

Twigs are slender, reddish brown, and smooth.

\section{Buds:}

$1 / 8^{\prime \prime}$, reddish brown, sharp pointed and glabrous.
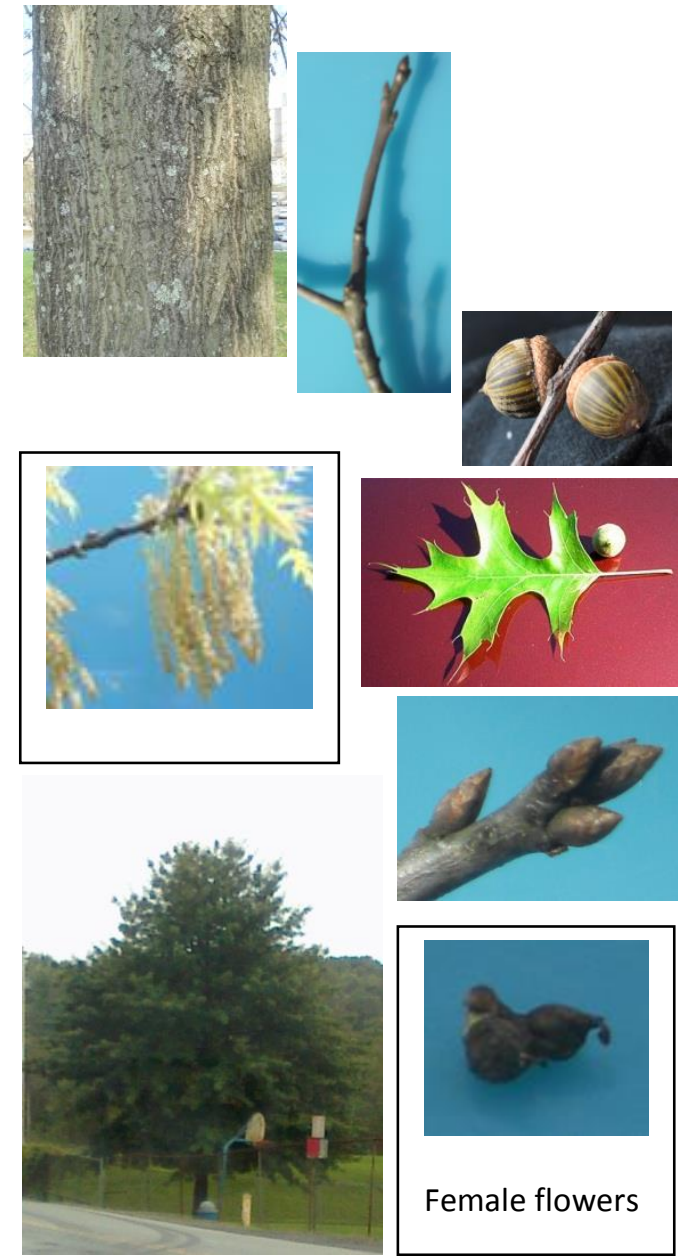

Pin oak is intolerant of shade and has a rapid growth rate. It reaches a height of 50 to 80 feet and a diameter of 1 to 3 feet. Shallow furrows are often present on the bark of older trees. Flowers are yellowish brown in color, with staminate flowers appearing in catkins. An excellent way to differentiate between Pin oak and Scarlet oak is that Pin oak lacks C-shaped sinuses in its leaves. Pin oak is frequently planted as an ornamental, but has poor timber quality. Pin oak is a member of the red oak group. 
Nuttall oak

Quercus nuttallii

Fagaceae

\section{Leaves:}

4-8" long, alternate, glabrous, dark green, obovate, 5 to 7 lobed, lobes bristle tipped, separated by deep sinuses; deciduous. ${ }^{1}$

\section{Flowers/Fruit:}

Flowers are monoecious; fruit is $3 / 4-11 / 4$ ", reddish brown, an acorn, striate, $1 / 4-1 / 2$ enclosed in deep thick cap. $^{2}$

\section{Twigs:}

Twigs are moderately slender, gray-brown to reddish brown, glabrous.

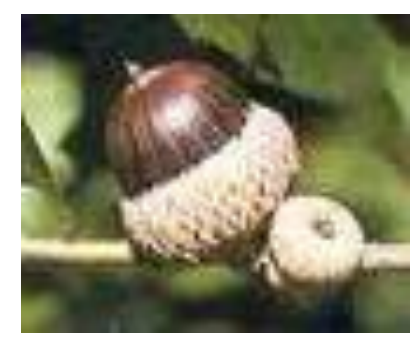

\section{Buds:}

To $1 / 4 "$, slightly angled, gray-brown scales, somewhat pubescent.
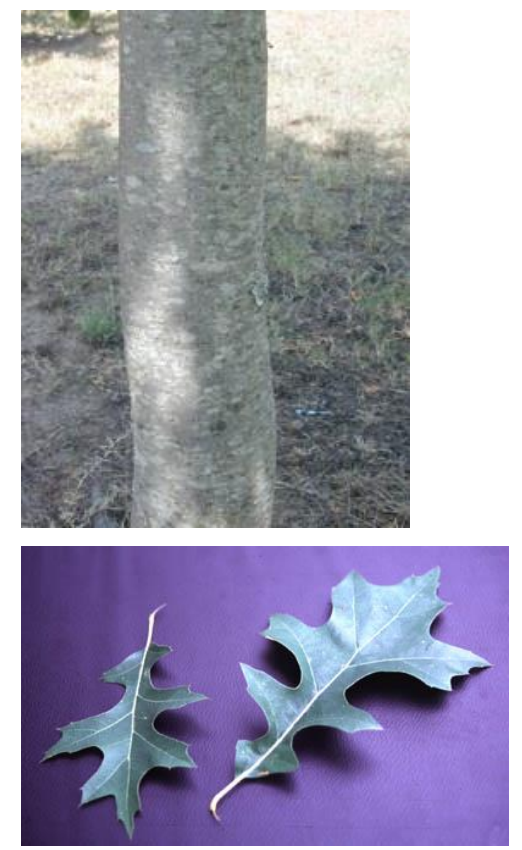

Nuttall oak is intolerant of shade and has a rapid growth rate. It typically grows to a height of 60 to 80 feet and a diameter of 1 to 3 feet. Leaves turn reddish in the fall. Flowers are yellowish brown and appear in the spring, with the staminate flowers in catkins. Nuttall oak prefers to grow in wet, bottomland flats. Nuttlle oak losses all of its leaves in the fall, unlike many Quercus spp. Nuttlle oak belongs to the red oak group and is used for timber. 


\section{Blackjack oak}

\section{Quercus marilandica}

Fagaceae

\section{Leaves:}

3" to 6" long, alternate, quite variable, shallowly 3lobed, tawny, dark green, leathery, pubescent below; deciduous.

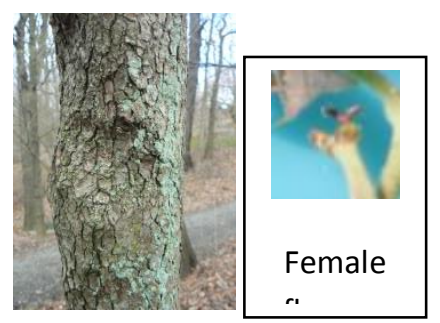

\section{Flowers/Fruit:}

Flowers are monoecious; fruit is $3 / 4^{\prime \prime}$, oblong, an acorn, $1 / 2$ enclosed in thick bowl-shaped cap, with hairy, reddish brown scales.

\section{Twigs:}

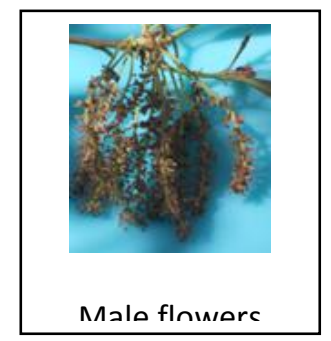

Twigs are stout, greyish brown, somewhat pubescent.

\section{Buds:}

$1 / 4^{\prime \prime}$, angled, similar to black oak but reddish brown.
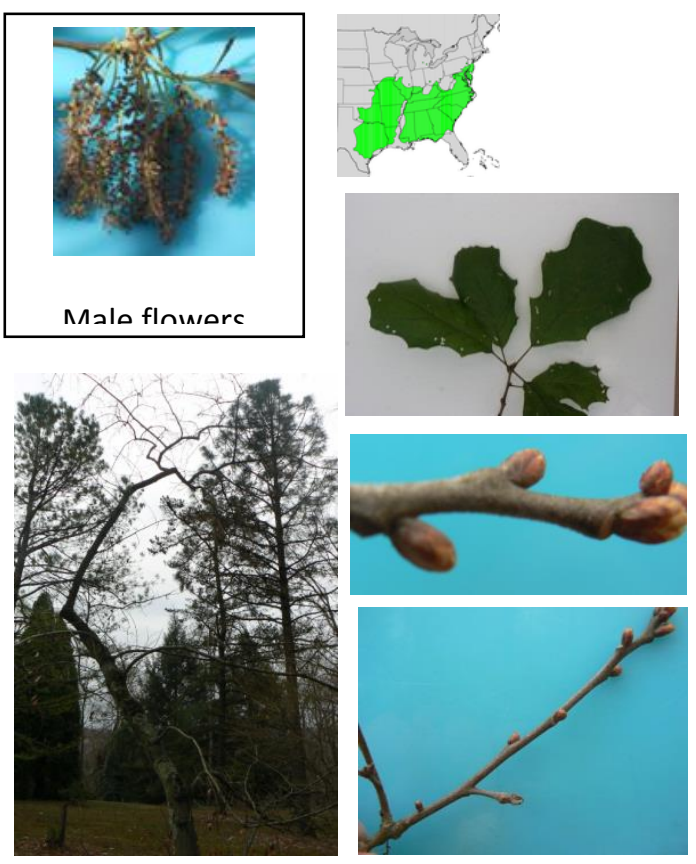

Blackjack oak is intolerant of shade and has a slow growth rate. It reaches a height of 20 to 40 feet and a diameter of 1 foot. Flowers are brownish with staminate flowers in catkins. Fall foliage is yellowish brown. Lobes of leaves are bristle tipped. The hard, durable wood may be used for timber, if it grows large enough. Blackjack oak typically grows on poor, dry sites. Blackjack oak has a spreading crown with an irregular branching pattern. Blackjack oak is a member of the red oak group. 
Turkey oak

Quercus laevis

Fagaceae

\section{Leaves:}

3 " to 12 " long, quite variable in size and shape, dark green, 3-7 bristle tipped lobes; deciduous. ${ }^{1}$

\section{Flowers/Fruit:}

Flowers are monoecious; fruit is 1 ", oval, an acorn, brown; $1 / 3$ enclosed in a thin bowl-shaped cap. ${ }^{2}$

\section{Twigs:}

Twigs are stout, dark brown.

\section{Buds:}

up to $1 / 2 "$, narrow, rusty pubescent, greyish brown. ${ }^{3}$
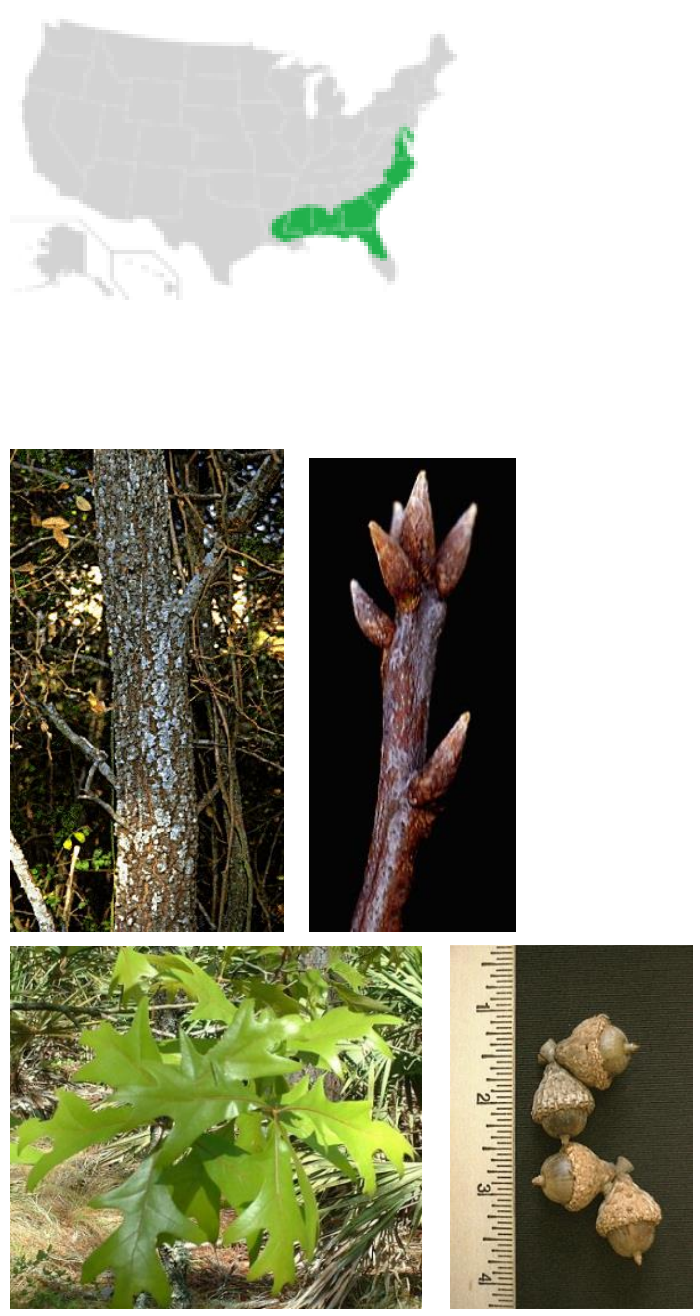

Turkey oak is intolerant of shade and has a moderate growth rate. It grows to a height of 20 to 40 feet and a diameter of 1 to 2 feet. Turkey oak typically has an irregular crown. It generally grows on sandy, dry sites. The name derives from the resemblance of the leaves to a turkey's foot. Fall color is reddish brown. Flowers appear in the spring with staminate flowers in catkins. Turkey oak is a member of the red oak group.

1: Photo courtesy of http://commons.wikimedia.org/wiki/File:AmericanTurkeyOakLeaves.jpg

2: Photo courtesy of http://dendro.cnre.vt.edu/dendrology/sy/labus/factsheet.cfm?ID=167

3: Photo courtesy of http://dendro.cnre.vt.edu/dendrology/sy/labus/factsheet.cfm?ID=167 
Willow oak

Quercus phellos

Fagaceae

\section{Leaves:}

2-5" long, alternate, 1/3-1" wide; linear-lanceolate,

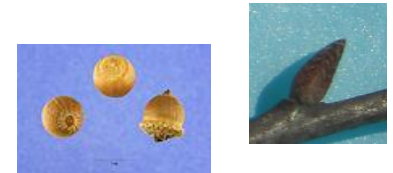
light to dark green, entire margin, with a bristle at the end; deciduous to semi-evergreen.

\section{Flowers/Fruit:}

$1 / 2$ " or shorter, an acorn, brownish with black bands, $1 / 4$ of nut enclosed by a thin cap. ${ }^{1}$

\section{Twigs:}

Flowers are monoecious; twigs are slender, red to reddish brown.

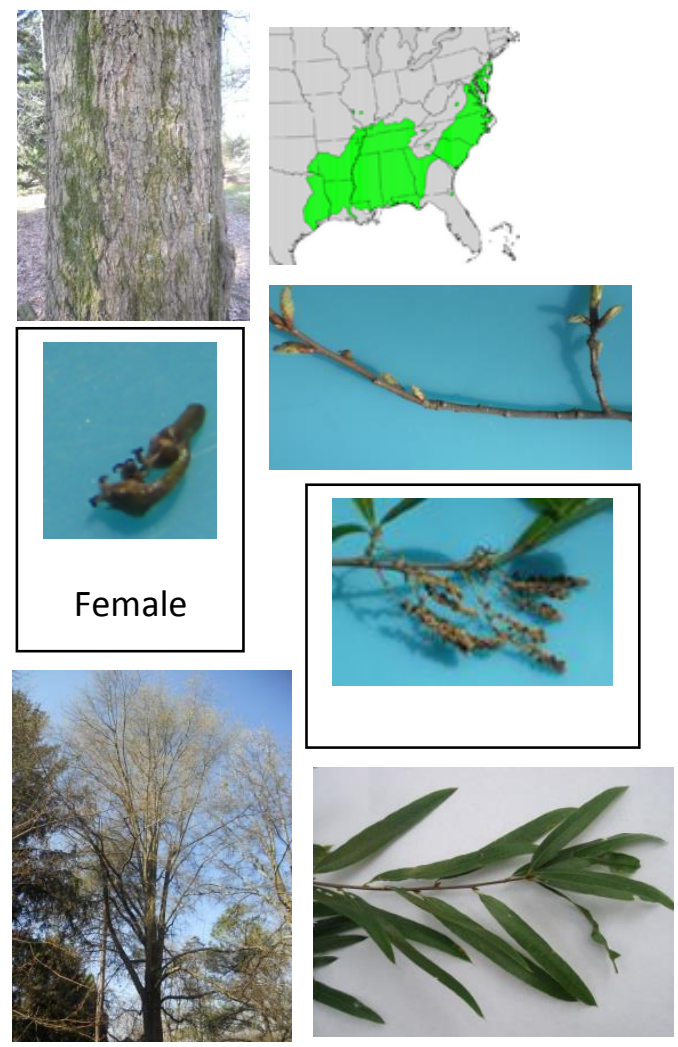

Willow oak is intolerant of shade and has a rapid growth rate. It reaches a height of 80 to 100 feet and a diameter of 2 to 4 feet. Leaves, if deciduous, turn yellowish brown in the fall. Flowers are yellowish brown with staminate flowers in catkins. Willow oak has a pyramidal crown in youth, but becomes dense and rounded with age. Willow oak is frequently planted as an ornamental, and will tolerate a variety of growing conditions. It prefers to grow on bottomland sites. It is a member of the red oak group. 
Water oak

Quercus nigra

Fagaceae

\section{Leaves:}

2-4" long, alternate, often 3-lobed, usually entire, semi evergreen in warm climate areas; variable in size and shape. ${ }^{1}$

\section{Flowers/Fruit:}

Flowers are monoecious ${ }^{2}$; fruit is $1 / 2$ ", an acorn, dark brown, hemispherical, black striate, enclosed at base by thin, hairy, saucer-like cap. ${ }^{3}$

\section{Twigs:}

Twigs are slender, dull red, and smooth. ${ }^{4}$

\section{Buds:}

$1 / 8-1 / 4^{\prime \prime}$, sharp pointed, covered with brown scales, hairy.
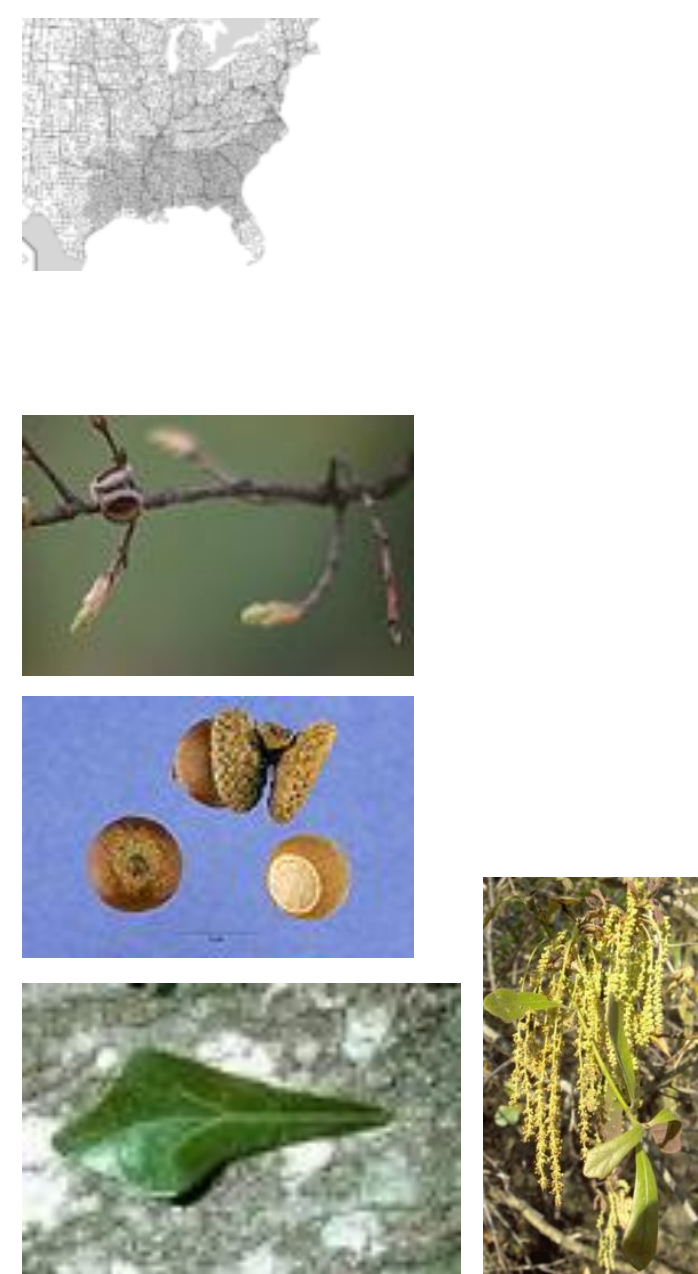

Water oak is intolerant of shade and has a rapid growth rate. It grows to a height of 60 to 70 feet and a diameter of 2 to 3 feet. Flowers are yellowish brown, with staminate flowers appearing in catkins. Fall foliage, if present, is yellow. Water oak is typically found in bottomland sites. It generally has a rounded growth form. Uses include timber and ornamental. Water oak is a member of the red oak group.

1: Photo courtesy of http://commons.wikimedia.org/wiki/Category:Quercus_nigra

2: Photo courtesy of http://commons.wikimedia.org/wiki/File:Quercus_nigra_Water_Oak_catkins.jpg

3: Photo courtesy of http://commons.wikimedia.org/wiki/Category:Quercus_nigra

4: Photo courtesy of http://commons.wikimedia.org/wiki/Category:Quercus_nigra 
Shingle oak

\section{Quercus imbricaria}

Fagaceae

\section{Leaves:}

4- 6" long, alternate, oblong to elliptical, entire, pubescent below, tipped with needle-like bristle; deciduous.

Flowers/Fruit:

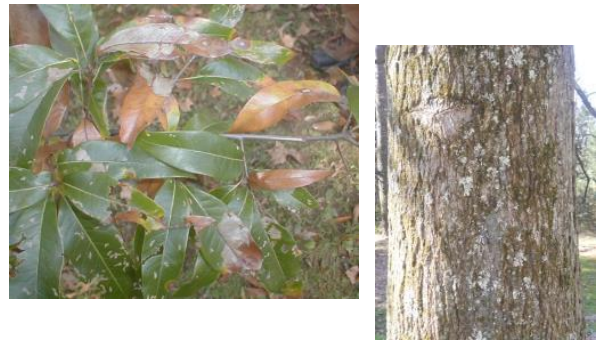

$5 / 8^{\prime \prime}$, an acorn, dark brown, subglobose; enclosed $1 / 3$ to $1 / 2$ in by hairy, thin red-brown cap.

\section{Twigs:}

Twigs are slender, dark green to greenish brown, shiny.

\section{Buds:}

1/8", ovoid, pointed, brown.
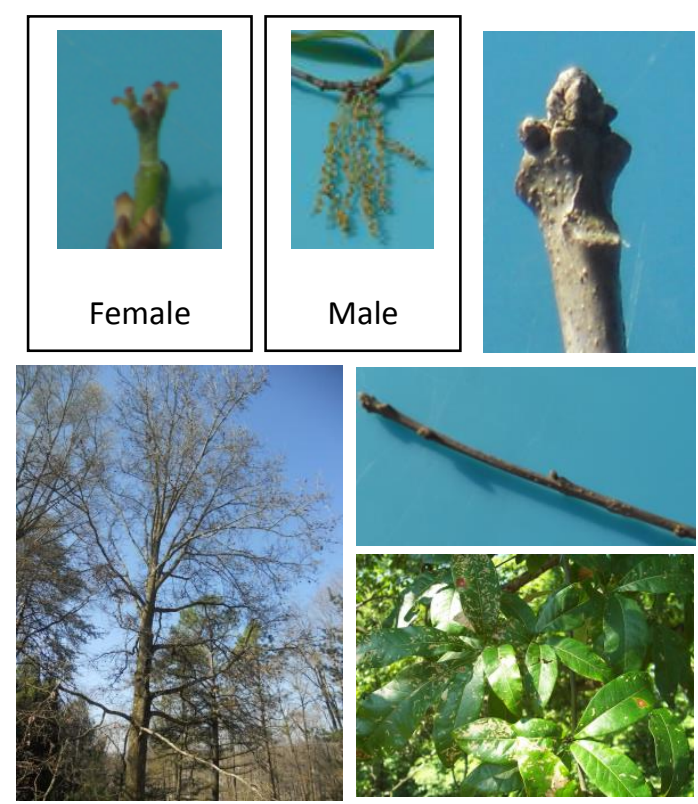

Shingle oak is intermediate in shade-tolerance and has a slow growth rate. It reaches a height of 40 to 70 feet and a diameter of 1 to 3 feet. Flowers are yellowish brown in color, staminate flowers in catkins. Leaves turn yellow, brown, and may be reddish in the fall. Leaves are typically marcescent. Shingle oak has a rounded to oval shaped crown. It was once used to make shingles. Shingle oak generally grows on moist sites. It is a member of the red oak group. 
Live oak

Quercus virginiana

Fagaceae

\section{Leaves:}

2 -5" long, alternate, oblong, entire, dark glossy green, paler and pubescent below; evergreen, persisting until spring when they are replaced by new leaves.

Flowers/Fruit:
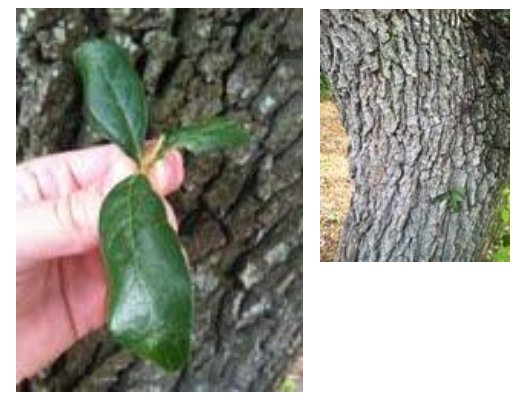

Flowers are monoecious; fruit is $3 / 4 "$, dark brown to black; $1 / 3$ enclosed in turbinate cap

Twigs:

Twigs are slender and grey.
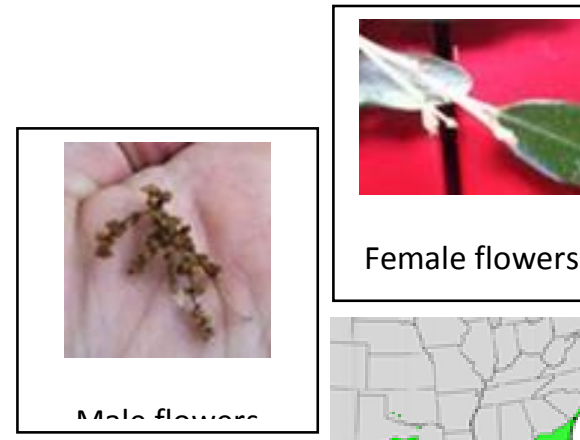

Female flowers

\section{Buds:}

$1 / 16$ to $1 / 4$ " long, red-brown.
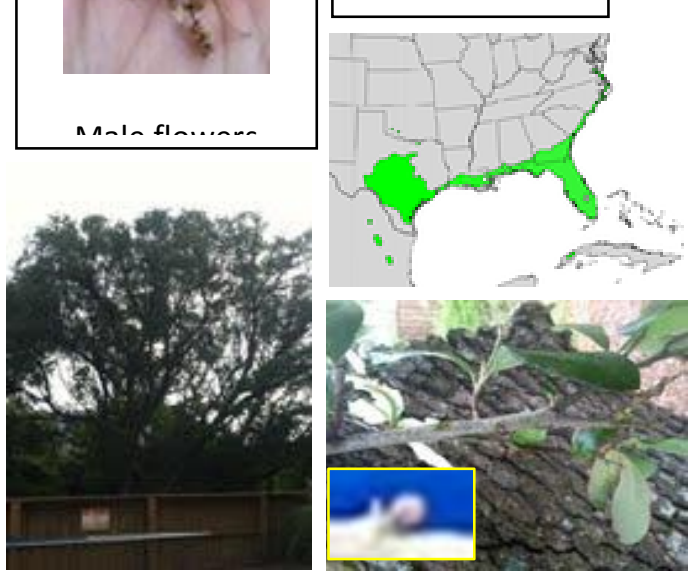

Live oak is intolerant of shade and has a rapid growth rate. Live Oak grows to a height of 50 to 80 feet and a diameter of 3 to 4 feet. Flowers appear in the spring, are yellowish brown in color, with staminate flowers in catkins. Live oak has a wide spreading crown (60 to 100 feet) of arching branches that are often covered in Spanish moss (Tillandsia usneoides). The acorns of Live oak mature in one season. It is often used as an ornamental in the southern U.S. Live oak is a member of the red oak group. 
Yellow birch

\section{Betula alleghaniensis}

Betulaceae

\section{Leaves:}

$3-4 \frac{1}{2}$ "long, alternate, ovate, doubly serrate, dark green above, stem hairy; deciduous.

\section{Flowers/Fruit:}

Flowers appear in the spring, and consist of yellowish catkins; fruit is ovoid, sessile, an erect strobile, 1-1 $1 / 2 "$, brown.

\section{Twigs:}

Slender, yellow brown, with wintergreen odor.

\section{Buds:}

Terminal absent, laterals chestnut brown, $1 / 4$ " long, appressed against the twig.
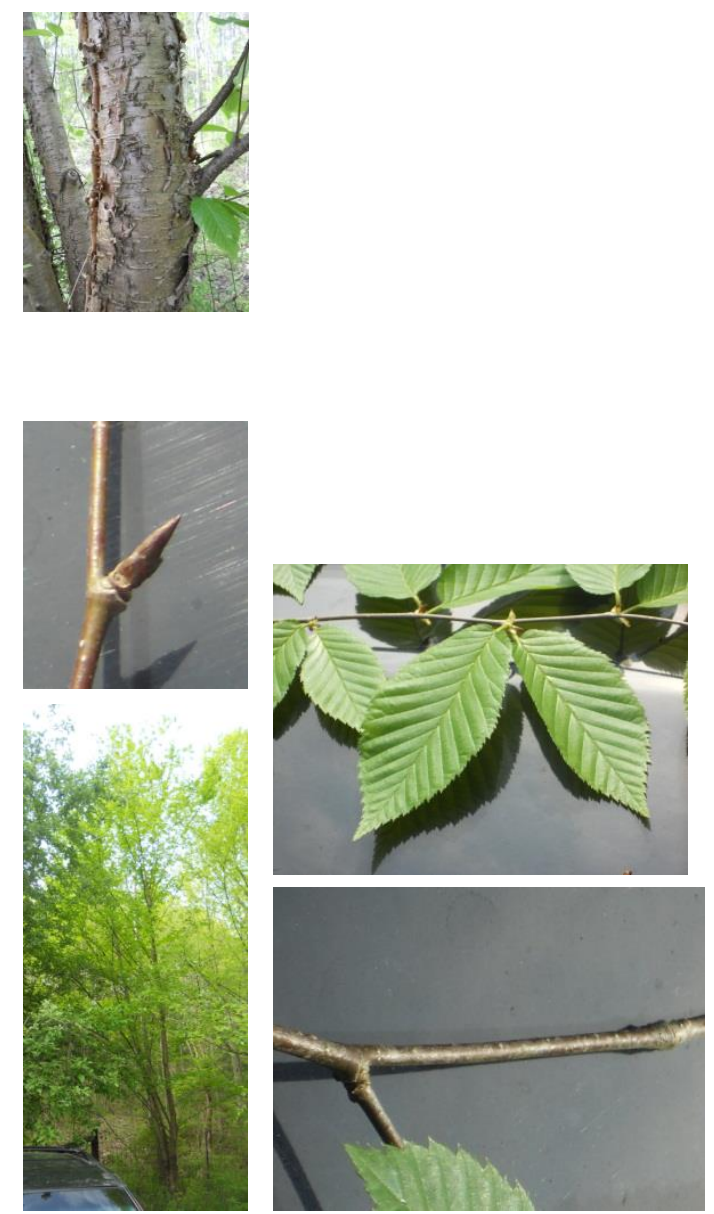

Yellow birch is moderately tolerant of shade and has a slow growth rate. It reaches a height of 70 to 100 feet and a diameter of 1 to 2 feet. Leaves turn Yellow in the fall. In the southern Portion of its range, it is found at only high elevations. It is found on moist uplands throughout its range. Its wintergreen odor is less pronounced than that of Sweet birch (Betula lenta). Yellow birch is used for lumber. 
Black birch, Sweet birch

Betula lenta

Betulaceae

\section{Leaves:}

$2 \frac{1}{2}-5^{\prime \prime}$, alternate, ovate, sharply double serrate, dark green, stem hairy; deciduous.

\section{Flowers/Fruit:}

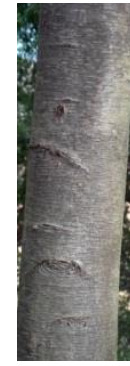

Flowers are $1 / 2$ to 1 " long catkins; fruit is ovoid, brown, short-stalked, an erect strobile, $1-1 \frac{1}{2}{ }^{\prime \prime}$; matures in late summer to fall.

\section{Twigs:}

Twigs are slender, reddish brown, glabrous, aromatic (wintergreen).

\section{Buds:}

Terminal absent, laterals $1 / 4$ " lustrous, sharply pointed, chestnut brown.
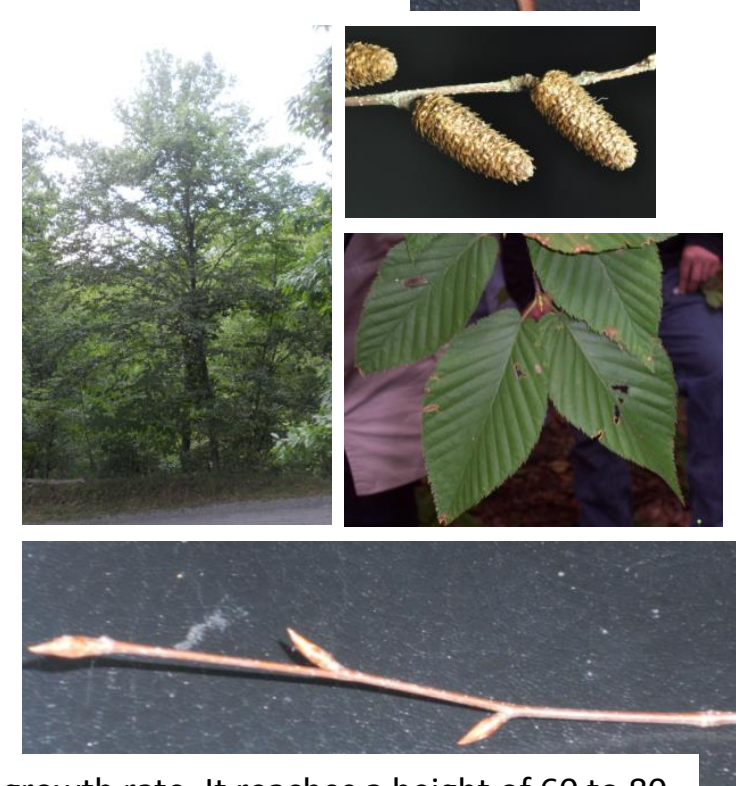

Black birch is moderately shade-tolerant and has a slow growth rate. It reaches a height of 60 to 80 feet and a diameter of 2 feet. The pinkish to yellow brown flowers appear in mid spring. Small branches are lined with small spur shoots, each having two leaves during the growing season. Leaves turn golden yellow in the fall. Throughout the southern portion of its range, Sweet birch grows only at higher elevations. It will tolerate dry to moist sites. With age, Sweet birch will develop an oval to rounded crown. 
Paper birch

Betula papyrifera

Betulaceae

\section{Leaves:}

2-3", alternate, dark green, ovate to oval, coarsely doubly serrate, acute apex; deciduous

\section{Flowers/Fruit:}

Flowers are yellowish brown catkins which appear in the spring; fruit is pendent, cylindrical, a stalked strobile, 1-1 1/2" long, brown.

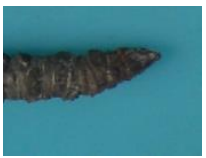

\section{Twigs:}

Slender, dull reddish-brown to orange-brown, lenticellate.

\section{Buds:}

Terminal bud absent, laterals $1 / 4$ to $1 / 2$ " long, ovoid, gummy, chestnut brown, glabrous.
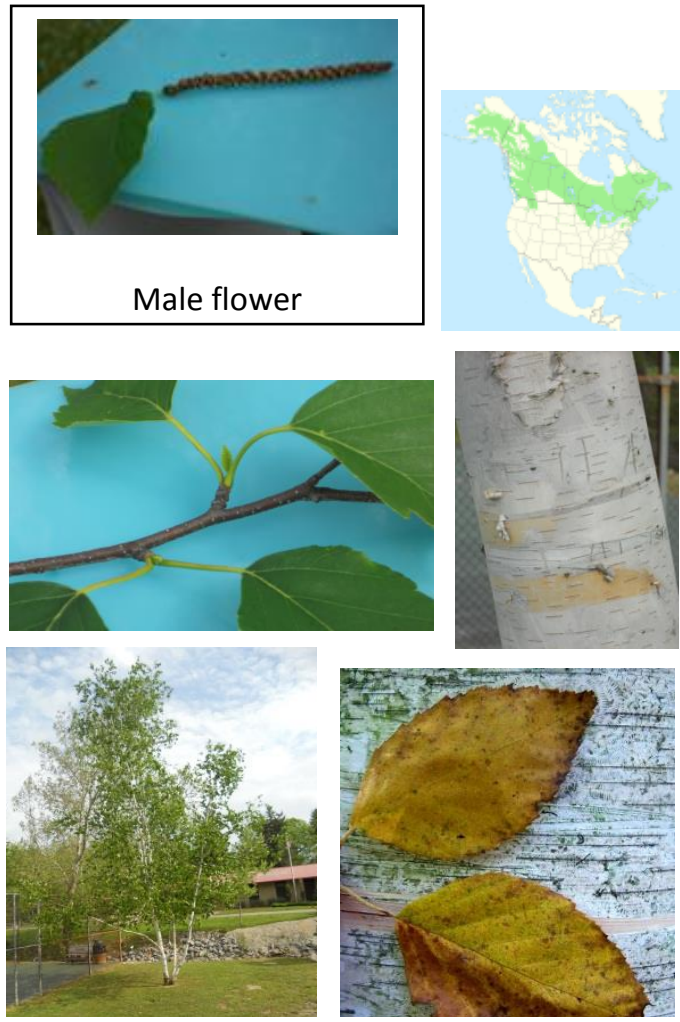

Paper birch is intolerant of shade and has a rapid growth rate. It reaches a height of 70 to 80 feet and a diameter of 2 feet. The Alaska variant is named as Betula neoalaskana. The leaves turn yellow in the fall. Smaller branches are lined with small spur shoots. Older trees develop dark, deeply furrowed bark at the base of the trunk. The fruits mature in late summer to autumn. Paper Birch develops an open crown with age. It generally grows on moist sites, and areas that have been burned. Paper birch is often planted as an ornamental. 
River birch

Betula nigra

Betulaceae

\section{Leaves:}

1.5 to 3 " long, alternate, rhombic-ovate, deeply double serrate, broadly wedge-shaped base, dark green; deciduous.

\section{Flowers/Fruit:}

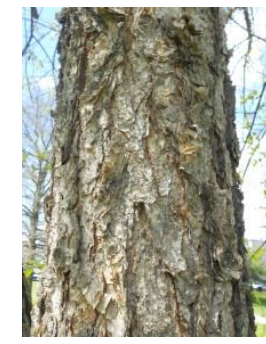

Flowers are in catkins and appear in the spring; fruit is a cylindrical, erect, pubescent strobile with deciduous scales, matures late in spring.

\section{Twigs:}

Twigs are slender, reddish brown, with warty excrescences.

\section{Buds:}

Terminal absent, laterals $1 / 4$ " long, brown.

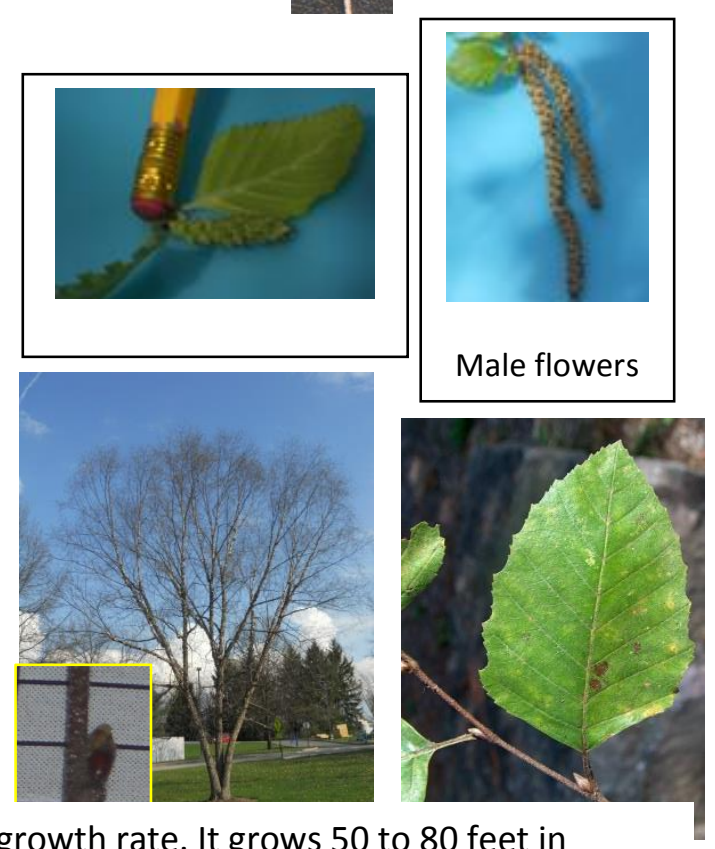

River birch is moderately shade-tolerant and has a slow growth rate. It grows 50 to 80 feet in height and 3 feet in diameter. River birch generally has a pyramidal shaped crown in youth, but becomes rounded to irregular. The tree often splits into several stems close to the ground. The leaves turn a butter yellow color in the fall. River birch typically grows on moist sites. Its range extends much further south than any other native birch species, and it is the only birch native to eastern Texas. River birch is commonly used as an ornamental. 
Red alder

Alnus rubra

Betulaceae

\section{Leaves:}

3-6", alternate, ovate to elliptical, doubly serrate, dark green above, with brownish hairs beneath, petiole grooved; deciduous, turning brownish in the fall. ${ }^{1}$

\section{Flowers/Fruit:}

Flowers consist of catkins which appear in the spring ${ }^{2}$; fruit is oblong to ovoid, brown, a stalked strobile $1 / 2-1$ $1 / 4^{\prime \prime}{ }^{3}$

\section{Twigs:}

Moderately stout, bright red to reddish brown.

\section{Buds:}

$1 / 3-1 / 2{ }^{\prime \prime}$, stalked, $2-3$ red, pubescent scales. ${ }^{4}$
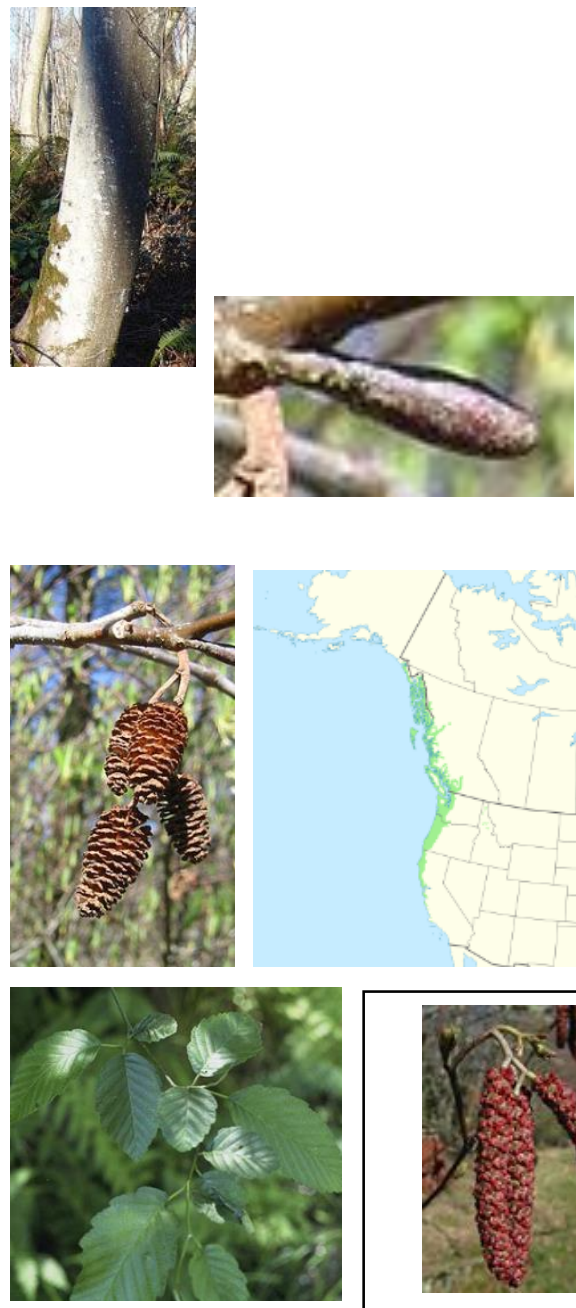

Red alder is intolerant of shade and has a rapid growth rate. It reaches a height $\mathrm{d}$

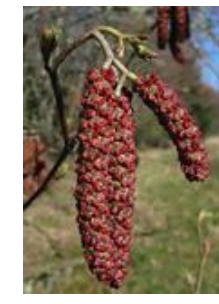
a diameter of 1 to 2 feet. The staminate catkins are reddish to green-brown in color. Red alder develops a dome shaped crown. Red alder grows on moist sites and cut-over lands. Red alder establishes disturbed sites, and improves the site for later successional species by adding organic matter and nitrogen to the soil. Red alder is used for timber and is the most important hardwood species in the Pacific Northwest area of the U.S.

1: Photo courtesy of http://commons.wikimedia.org/wiki/File:Red_alder_leaves.jpg

2: Photo courtesy of http://commons.wikimedia.org/wiki/File:Alnus_rubra_9819.JPG

3: Photo courtesy of http://commons.wikimedia.org/wiki/File:Alnus_rubra_0020.JPG

4: Photo courtesy of http://commons.wikimedia.org/wiki/File:Alnus_rubra_0020.JPG

5: Photo courtesy of http://commons.wikimedia.org/wiki/File:Pacific_spirit_ubc.jpg

6: Image courtesy of http://commons.wikimedia.org/wiki/File:Alnus_rubra_range_map.svg 


\section{American hornbeam}

Carpinus caroliniana

Betulaceae

\section{Leaves:}

1 - 3" long, alternate, elliptical, doubly serrate, dark green and glabrous above, somewhat hairy beneath, with veins running parallel to each other from the center towards the margin; deciduous.

\section{Flowers/Fruit:}

Flowers are catkins that appear in early spring; fruit is a 3-lobed, leafy involucre; subtends a small nut, appears in 3 to 6 " long clusters.

\section{Twigs:}

Slender, red to brown, and lenticellate.
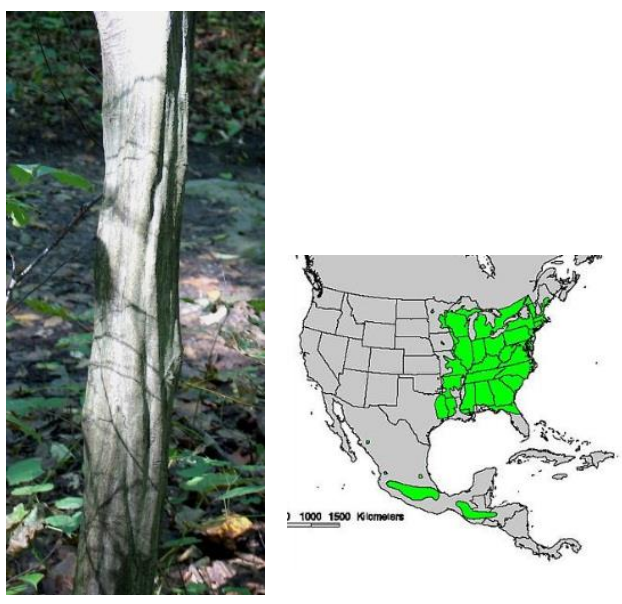

\section{Buds:}

$1 / 16$ to $1 / 4^{\prime \prime}$ long, brown, false terminal.

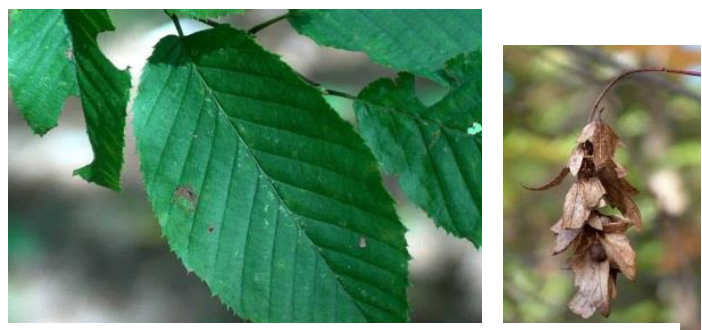

American hornbeam is very tolerant of shade and has a slow growth rate. It reaches a height of 25 to 40 feet and a diameter of 1 to 2 feet. The catkins are greenish yellow-brown in color. The fruits are green throughout the summer, but turn brown when mature in the fall. Leaves turn yellow to reddish in the fall. The twigs, although red to brown when young, turn grey with age. The buds are aligned close against the twigs. American hornbeam will grow on moist to dry sites, and is often found alongside streams. 
Eastern hophornbeam

Ostrya virginiana

Betulaceae

\section{Leaves:}

2 to 5 "long, doubly serrate, dark green and somewhat hairy above, lighter green and more hairy beneath; deciduous

\section{Flowers/Fruit:}

Flowers are monoecious. Fruit is a nut enclosed in oval, flattened, papery sacs, in clusters which are 1.5 to 2.5 " in length; yellow green, turning brownish when mature in the fall.

\section{Twigs:}
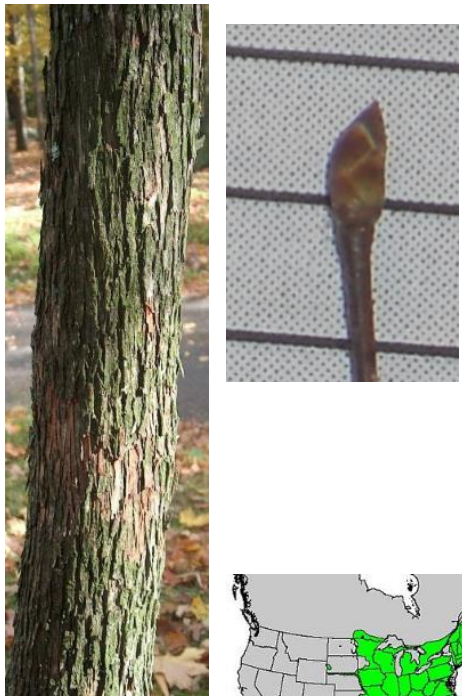

Slender, zig-zag in appearance, brownish.

\section{Buds:}

$1 / 8$ to $1 / 4$ " long, brown, round, yellowish green, false terminal.

Eastern hophornbeam is tolerant of shade and has a slow growth rate. It reaches a height of 20 to 40 feet and a diameter of 1 to 1.5 feet. The leaves turn yellow in the fall. The flowers, which are catkins, appear in the spring and are yellowish brown in color. The staminate catkins are preformed and are visible throughout the winter, before expanding in the spring. The clusters of fruits resemble hops. The growth form is generally rounded in shape. Eastern hophornbeam will grow on moist to dry rocky sites. 


\section{American basswood}

Tilia americana

Tiliaceae

\section{Leaves:}

5-6" long, 3-4" wide, alternate, dark green above, margin coarsely serrate, base unequal; deciduous

\section{Flowers/Fruit:}

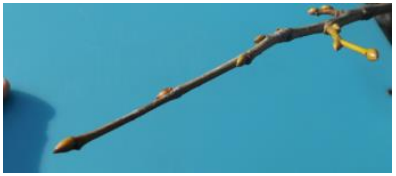

Flowers are small, yellowish white, very fragrant, and in clusters; fruit is $0.3^{\prime \prime}$, clustered, attached to bract, nut-like, brownish grey and tomentose.

\section{Twigs:}

Green to red becoming greyish brown with age, smooth, zigzag.

\section{Buds:}

$1 / 4 "$ long, 2 visible scales, green to red.
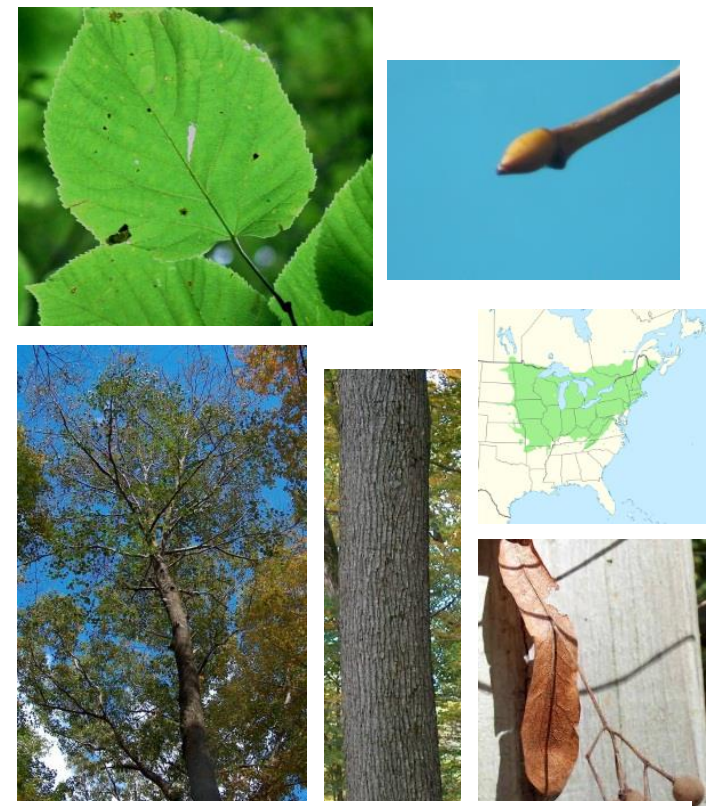

American basswood is tolerant of shade and has a rapid growth rate. It reaches a height of 60 to 90 feet and a diameter of 2 to 3 feet. The leaves turn yellow to brown in the fall, but may drop without any significant coloration. The very fragrant flowers appear in early summer and would likely go unnoticed without the intense odor given off. Twigs lack terminal buds. American basswood generally has a rounded crown. It develops a clear bole in the forest and is used for timber. It typically grows on fertile, moist sites. 
White basswood

Tilia heterophylla

Tiliaceae

\section{Leaves:}

3.5 to 6 " long, alternate, dark green and glabrous above, covered in whitish brown tomentose beneath, dentately toothed, with a long, thin apex; deciduous

\section{Flowers/Fruit:}

Flowers are small, whitish yellow, and appear in clusters; fruit is $1 / 3^{\prime \prime}$, nutlike, attached to a bract, greyish brown and tomentose.

\section{Twigs:}

Twigs are zigzag, reddish brown, and smooth.

\section{Buds:}

$1 / 4 "$, terminal bud absent, and reddish burgundy in color.
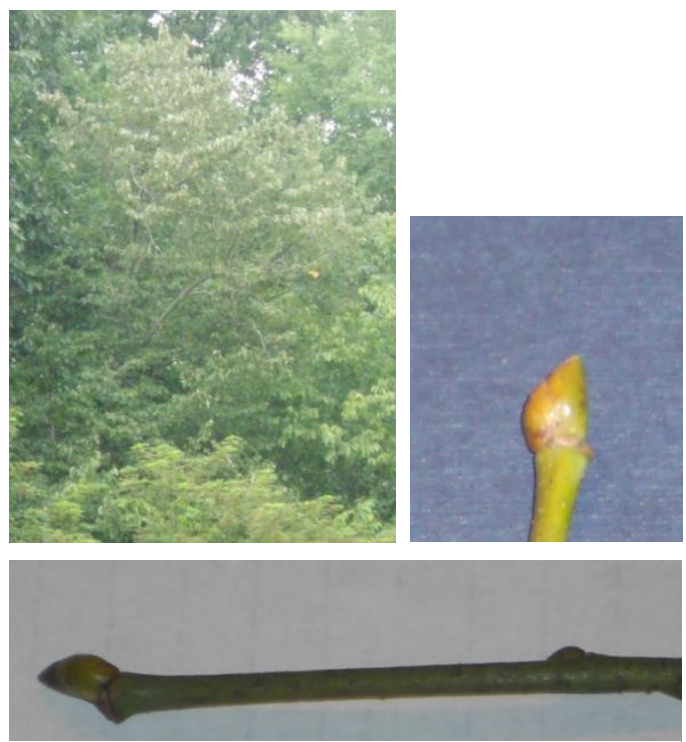

White basswood is tolerant of shade and has a rapid growth rate. It may grow to a height of 80 feet and a diameter of 1.5 to 2.5 feet. The leaves may turn yellow to brown in the fall, but often drop with little color present. The flowers appear in early summer and, like those of American basswood, are extremely fragrant. Outer scales of buds have hairs along the margins. It generally grows best on moist, well drained sites. White basswood has a rounded crown, a clear bole in forested settings, and is used for timber. 


\section{Leaves:}

3-6", alternate, dark green, lanceolate, finely serrate, base obtuse, large stipules present; deciduous.

\section{Flowers/Fruit:}

Flowers are catkins, appearing in the spring; fruit is $1 / 4{ }^{\prime \prime}$

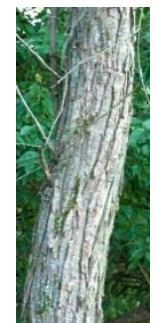
long, a capsule, glabrous, reddish brown.

\section{Twigs:}

Slender, purplish green to pale orange brown, smooth.

\section{Buds:}

Reddish-brown, 1/16" long, terminal absent, one scale covering the bud.
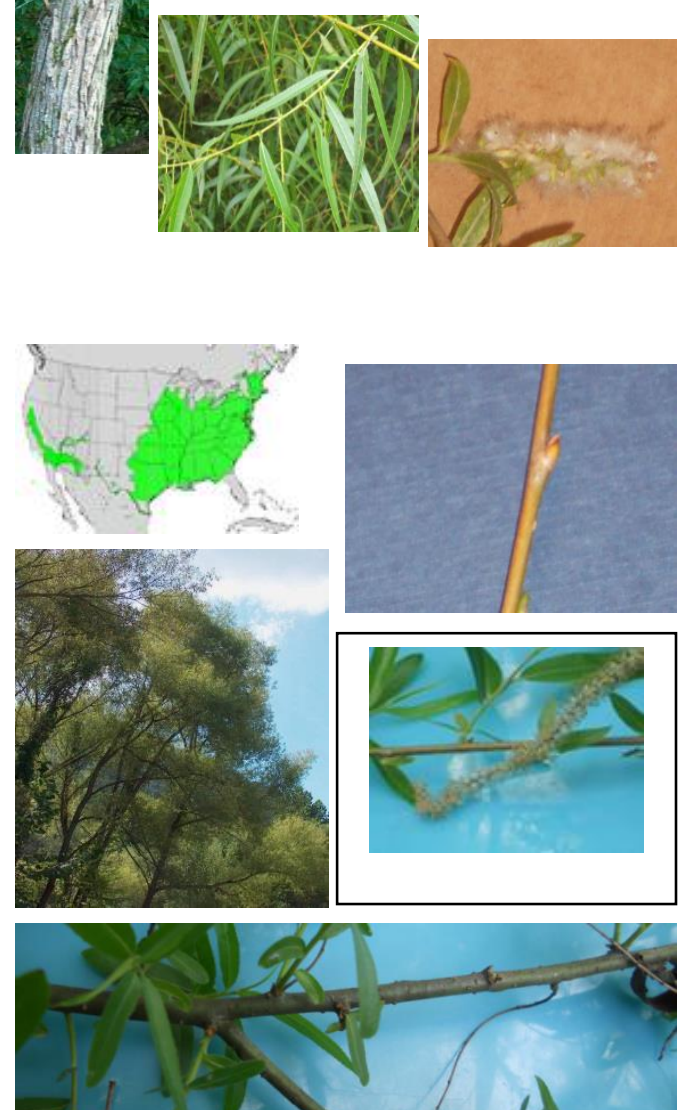

Black willow is very tolerant of shade and has a rapid growth rate. It reaches a height of 30 to 40 feet and a diameter of 1 to 1.5 feet. The leaves may turn yellow in the fall, but often drop with no significant coloration. Staminate catkins are yellowish in color, while pistillate catkins are whitish grey. The small fruits appear in 3-6" long clusters and mature during the summer. The twigs and small branches are very flexible and difficult to break, except for branch unions, where they are quite brittle. Prefers to grow on wet sites. 
Quaking aspen

Populus tremuloides

Salicaceae

\section{Leaves:}

$1 \frac{1}{2}-3^{\prime \prime}$ in diameter, alternate, suborbicular to broadly ovate, finely serrate margin, dark green, flattened petioles; deciduous

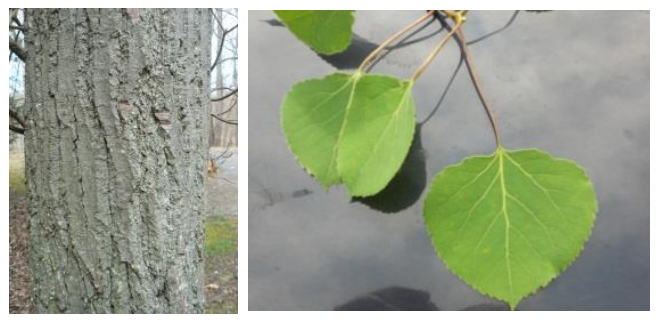

\section{Flowers/Fruit:}

Flowers are dioecious, catkins; fruit is $1 / 4$ " long, a capsule, light green, narrowly conical.

\section{Twigs:}

Twigs are slender, lustrous, reddish brown.

\section{Buds:}

Around $1 / 4 "$, conical, sharp-pointed, $6-7$ reddish brown imbricated scales.
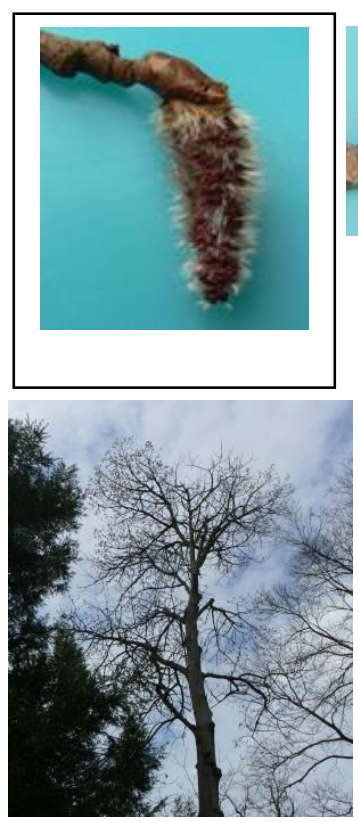

Quaking aspen is very intolerant of shade and has a rapid growth rate. It reaches a height of 30 to 70 feet and a diameter of 1 to 2 feet. The leaves quake in the slightest breeze due to the flattened petioles and turn yellow to orange in the fall. The flowers are greyish brown and appear in the very early spring. The fruits are borne in long thin clusters, and mature in late spring to early summer. Bark often develops an "aspen eye" due to the persistent dark colored branch scars. Quaking aspen is the most widely distributed tree in North America. 
Bigtooth aspen

Populus grandidentata

Salicaceae

\section{Leaves:}

3 to 4 " long, alternate, larger than quaking aspen, coarsely toothed, dark green, flattened petioles; deciduous.

\section{Flowers/Fruit:}

Flowers are catkins and are dioecious; fruit is $1 / 4$ to $1 / 2$, a capsule containing many small seeds, light green in color, occurring in thin, 4 to 6 " long clusters; matures in the spring.

\section{Twigs:}

Twigs are stout, dull brownish gray.

\section{Buds:}

$1 / 4$ to $1 / 2 "$, pointed, gray, puberulous.
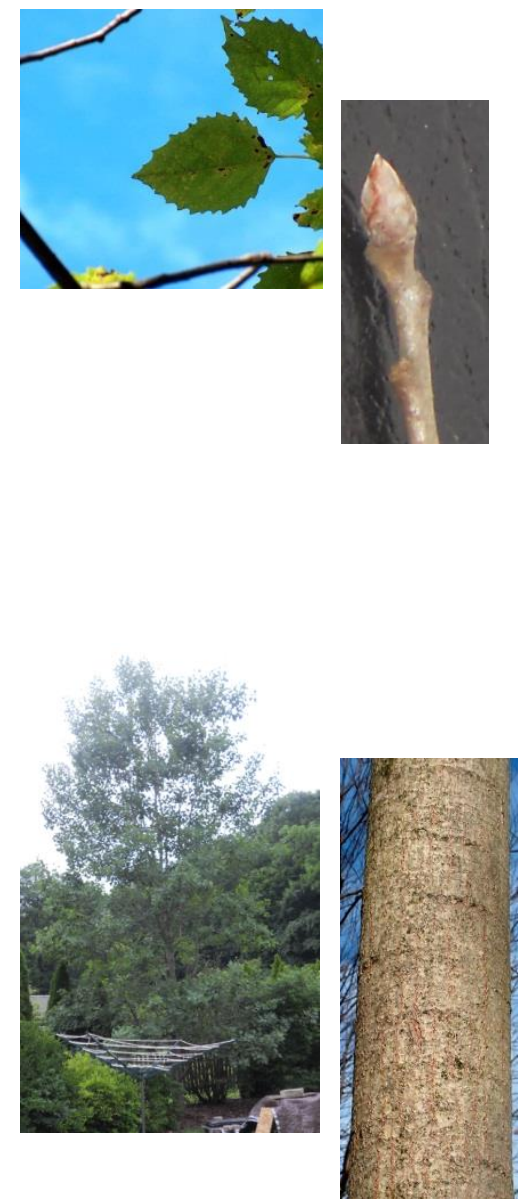

Bigtooth aspen is intolerant of shade and has a rapid growth rate. It reaches a height of 50 to 70 feet and a diameter of 1 to 2 feet. The leaves turn yellow to orange in the fall. The flowers are reddish yellow, to greyish brown in color and appear in very early spring. Bark is somewhat variable, with some trees having deeply furrowed dark colored bark. Bigtooth aspen will tolerate a variety of sites. It is more tolerant of heat, and is longer lived than Quaking aspen. It often has an irregular shaped crown and is used for pulpwood. 


\title{
Eastern cottonwood
}

\section{Populus deltoides}

\author{
Salicaceae
}

\section{Leaves:}

3-6" long, 4-5" wide, alternate, deltoid, serrate, glabrous with glands near the base, flattened petioles; deciduous.

\section{Flowers/Fruit:}

Flowers are catkins that appear in early spring and are dioecious; fruit is $1 / 4-1 / 3^{\prime \prime}$ long, a capsule, green, ovoid, 3 or 4 valved.

\section{Twigs:}
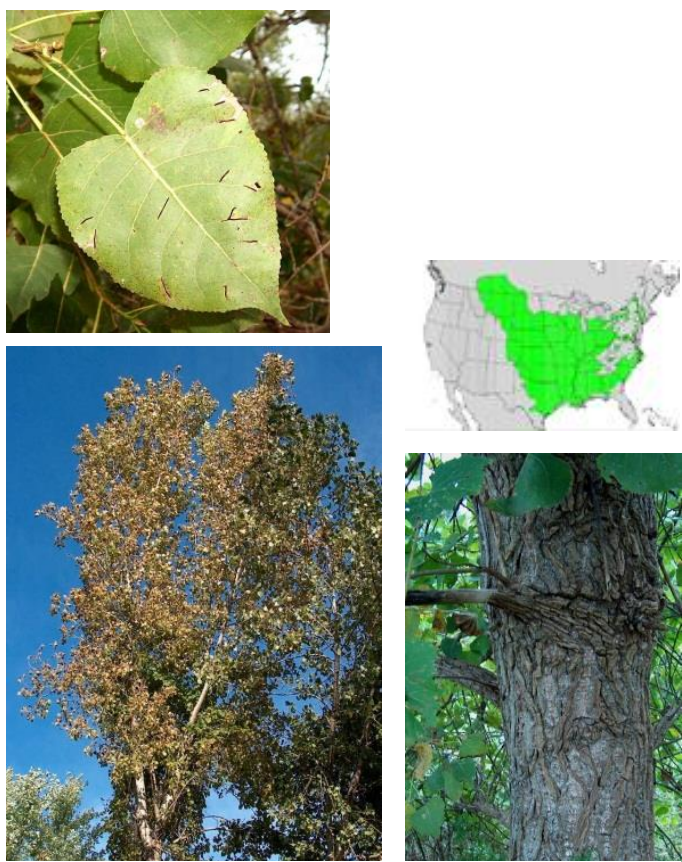

Eastern cottonwood is very intolerant of shade and has a rapid growth rate. It reaches a height of 75 to 100 feet and a diameter of 3 to 4 feet. The leaves turn yellow in the fall, but may drop without significant coloration as well. The catkins are yellowish to red in color. The fruits mature in the late spring to early summer, and are borne in 5 to 11 " clusters. Each fruit is filled with tiny cottony seeds. Buds are shiny. Eastern cottonwood generally has a rounded to irregular crown shape. It typically grows in floodplains and sandy soils. 
Black cottonwood

Populus trichocarpa

Salicaceae

\section{Leaves:}

5-6" long, ovate, dark green and glabrous above, finely crenate, and have round stems; deciduous.

\section{Flowers/Fruit:}

Dioecious flowers are catkins ${ }^{1}$; fruit is $1 / 3-1 / 2$ " long, a capsule, 3-valved, green, and pubescent.

\section{Twigs:}

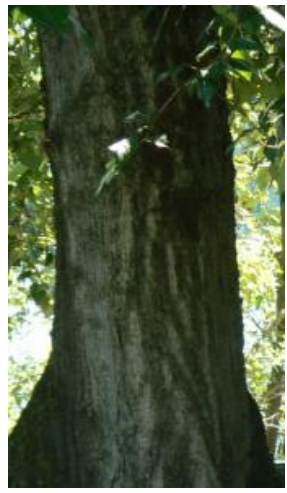

Twigs are slender, orange-brown to light yellowbrown, lenticellate.

\section{Buds:}

$3 / 4 "$, conical, 6 or 7 visible imbricated scales, resinous, fragrant.
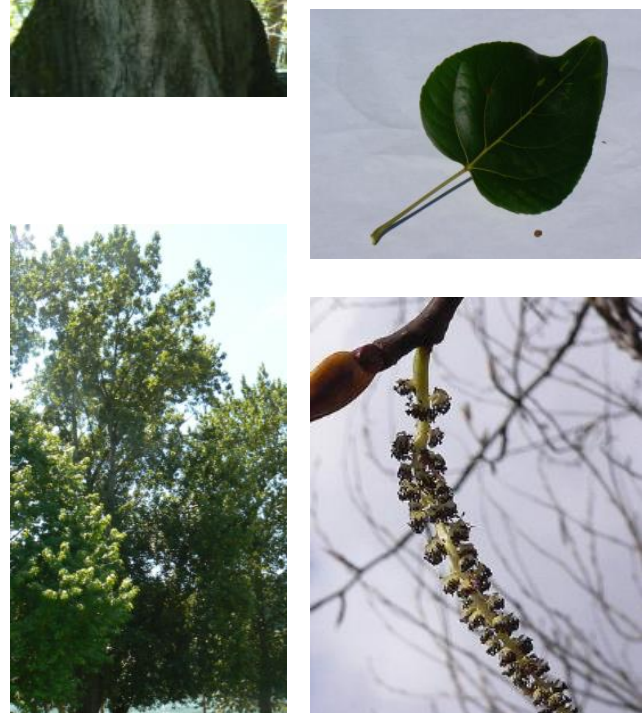

Black cottonwood is very intolerant of shade and has a rapid growth rate. It reaches a height of 80 to 125 feet and a diameter of 2 to 4 feet. Leaves turn yellow in the fall. The flowers appear in the early spring. Black cottonwood will grow on moist sandy and even gravelly sites. It generally has a conical to irregular crown shape. It's timber is used for pulp. 
Tree of heaven

Ailanthus altissima

Simaroubaceae

\section{Leaves:}

Large (1-3' long), alternate, pinnately compound, 13 to 35 stalked leaflets, leaflets are dark green with 2 to 4 teeth (glands at ends); deciduous.

\section{Flowers/Fruit:}
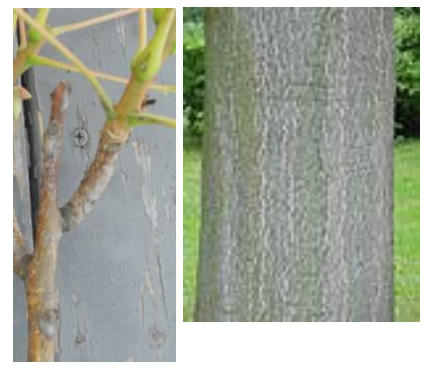

Flowers are dioecious ${ }^{1}$; fruits are 1 to $1.5^{\prime \prime}$ long, brown when mature, winged samaras, and persist on the tree in dense clusters throughout the fall and into the winter months. ${ }^{2}$

\section{Twigs:}

Stout, smooth, brown in color. ${ }^{3}$

\section{Buds:}

$1 / 8^{\prime \prime}$, finely pubescent, dome shaped, brown. ${ }^{4}$
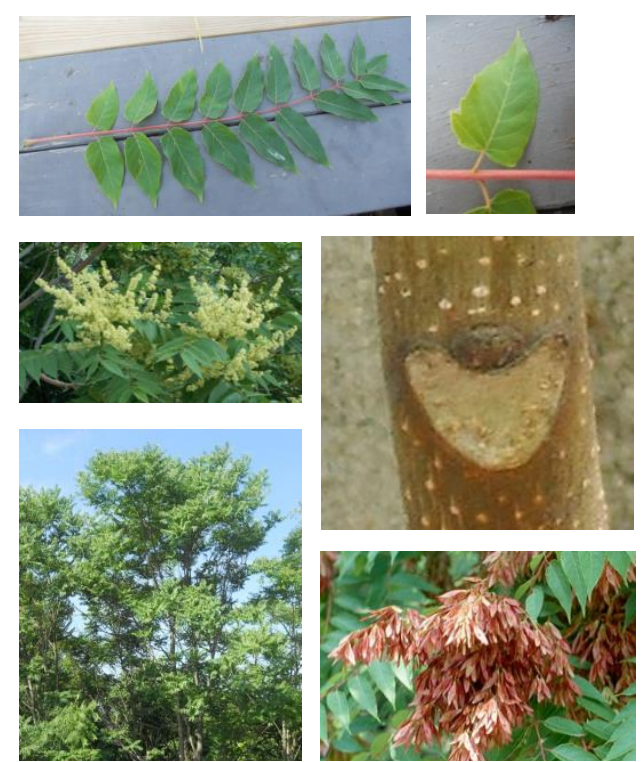

Tree of heaven is intolerant of shade and has a very rapid growth rate. It reaches a height of 50 to 80 feet and a diameter of 2 to 3 feet. The leaves turn yellow in the fall, but often drop with no significant coloration. Flowers are yellowish green and appear in the late spring to early summer in 8 to $16^{\prime \prime}$ clusters. The fruits are green to orange before maturing in the late summer to fall. The twigs may be lightly pubescent. Tree of heaven is considered a non-native, invasive species due its weedy habit and competition with desirable native plants. All plant parts have a bad odor.

1: Photo courtesy of http://commons.wikimedia.org/wiki/File:Arbre_\%C3\%AO_Sofia.jpg

2: Photo courtesy of http://commons.wikimedia.org/wiki/File:Ailanthus_altissima_RJB.jpg

3: Photo courtesy of http://commons.wikimedia.org/wiki/File:Ailanto___particolare.jpg 
Black cherry, Wild black cherry

Prunus serotina

Rosaceae

\section{Leaves:}

2-6" long, alternate, dark green, narrowly oval to oblong, finely serrate, incurved teeth, pubescent along midrib; deciduous.

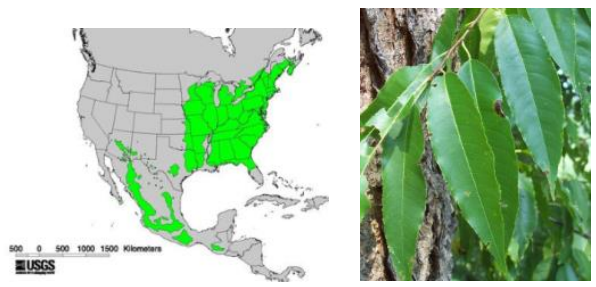

\section{Flowers/Fruit:}

Flowers are white, $1 / 3^{\prime \prime}$ in diameter, and borne in 4 to $6^{\prime \prime}$ long racemes; fruit is $1 / 3-1 / 2 "$, a drupe, red at first, black when ripe, maturing in late summer, edible, bitter. $^{1}$

\section{Twigs:}

Reddish brown, with many lenticels, bitter taste.

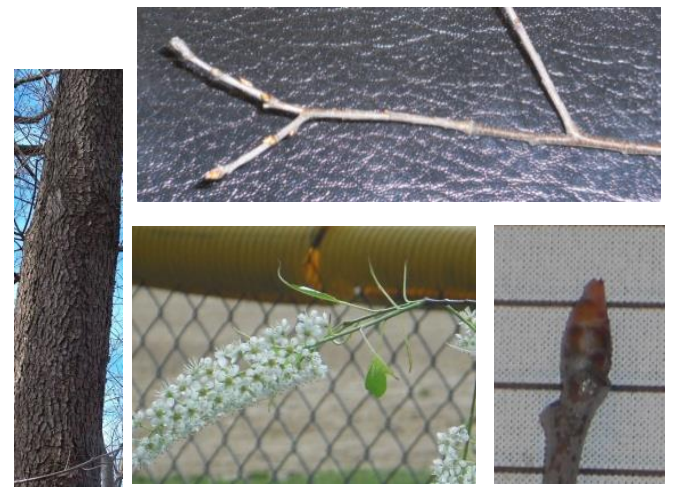

\section{Buds:}

$1 / 4 "$, ovate, chestnut brown, 3 bundle scars, shiny.
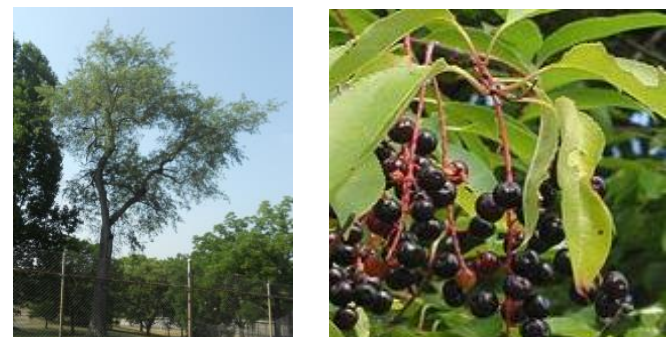

Black cherry is intolerant of shade and has a rapid growth rate. It reaches a height of 50 to 80 feet and a diameter of 1 to 3 feet. Petioles have several small glands present around the leaf base. Leaves turn yellow to orangish in the fall. The flowers appear in the late spring, and have five small petals. While the pitted fruits are edible, wilted leaves, twigs (stems), and seeds are poisonous. Black cherry is also native from the southwest U.S., southward through Mexico, and into Guatemala. Black cherry often has a clear bole, and is a valuable timber tree. 
Pin cherry

Prunus pensylvanica

Rosaceae

\section{Leaves:}

2 to 5 "long, alternate, lanceolate, yellow-green, smooth above, finely serrated, less shiny than black cherry; deciduous.

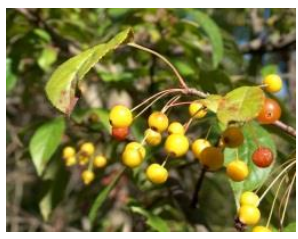

\section{Flowers/Fruit:}

Flowers are $1 / 2$ " across, and appear on $1 / 2$ to 1 " long stems in clusters of 4 to $5^{1}$; fruit is $1 / 4^{\prime \prime}$ through, a drupe, bright red, rounded, edible, sour, maturing in the summer.

\section{Twigs:}

Twigs are reddish, slender, prominent orange lenticels present and bitter taste.

\section{Buds:}

$1 / 8^{\prime \prime}$, ovate, chestnut brown, 3 bundle scars.
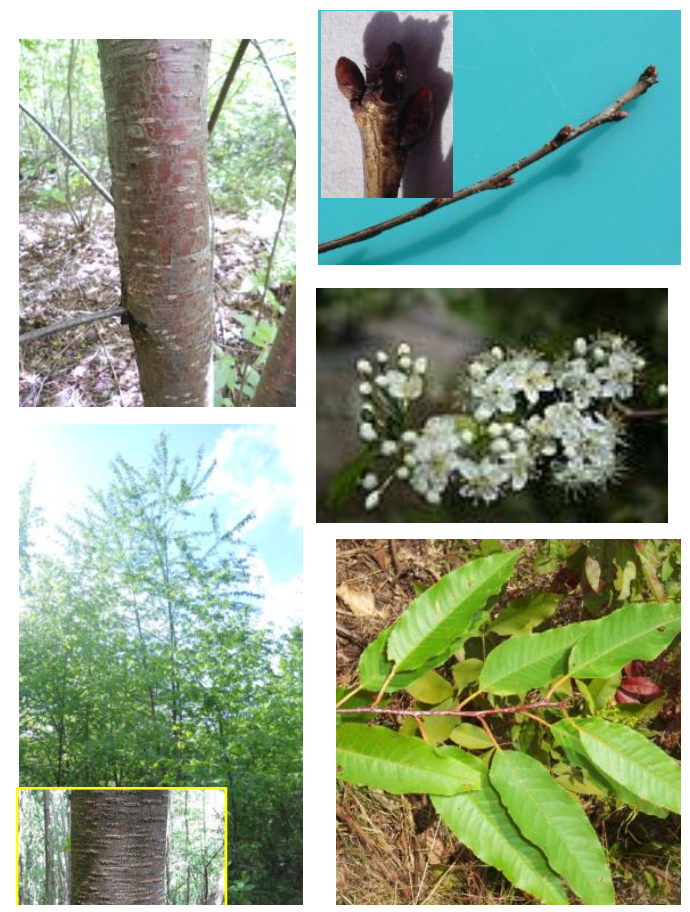

Pin cherry is intolerant of shade and has a rapid growth rate. It reaches a height of 25 to 40 feet and a diameter of 1.5 feet. The leaves turn yellow to red in the fall and the stems have 1 to 2 glands near the base of the leaf. The flowers are white and appear in mid spring. Short spurlike twigs are present on smaller branches. Pin cherry is very short lived, generally inhabits disturbed sites, and then succeeds to more permanent species. It typically has a conical crown in youth, but becomes rounded to irregular with age. 
Hawthorn, Thorn apple

\section{Crataegus spp.}

Rosaceae

\section{Leaves:}

1 to 4 " long, alternate, may be serrated, toothed, or lobed, generally dark green and smooth above; deciduous.

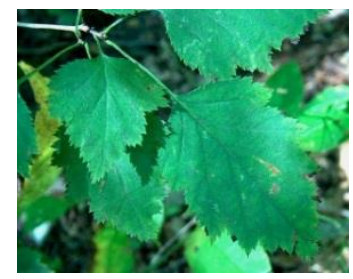

\section{Flowers/Fruit:}

Flowers are generally white, 0.3 to $1^{\prime \prime}$ across, and in clusters; fruit is 0.3 to 0.8 ", a pome, color ranges from yellow to red, and matures in the fall.

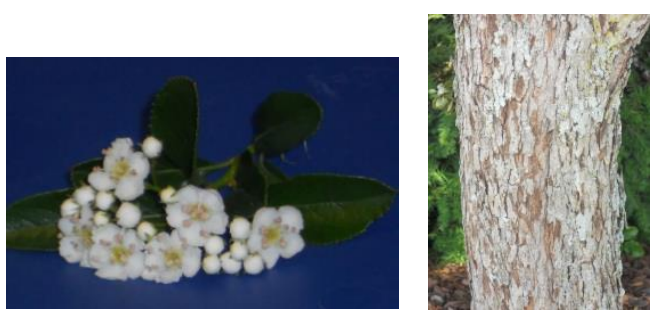

\section{Twigs:}

Orangish to grey-brown, 0.5 to 5 " long thorns.

\section{Buds:}
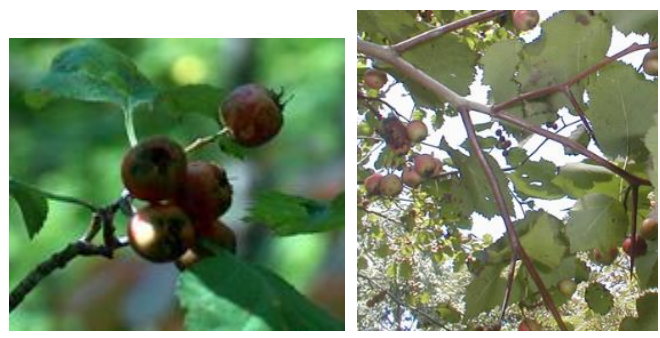

Small, rounded, reddish brown, smooth.
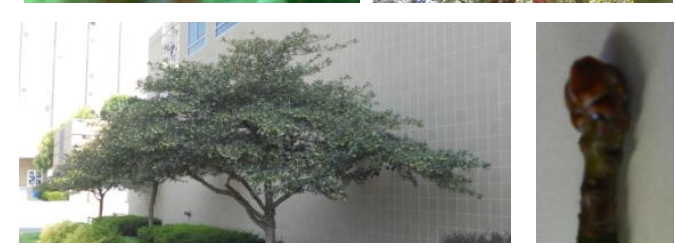

Hawthorn is fairly tolerant of shade and has a medium growth rate. Crataegus spp. generally reach a height of 20 to 35 feet and a diameter of 0.5 to 1 feet. The leaves vary greatly in shape and have stipules present. Fall coloration is usually not signifigant. It is not uncommon for the colorful fruits to persist into the winter. Flowers may appear with or before the leaves in early to late spring, depending on species. Hawthorn may be either a shrub or a small tree. There are as many as 1,000 species worldwide. 
Black locust

Robinia pseudoacacia

Fabaceae

\section{Leaves:}

7 to 15 " long, pinnately compound, alternate, 5 to 11 leaflets, leaflets $1 \frac{1}{2}-2$ " long, dark bluish green, entire; deciduous.

\section{Flowers/Fruit:}

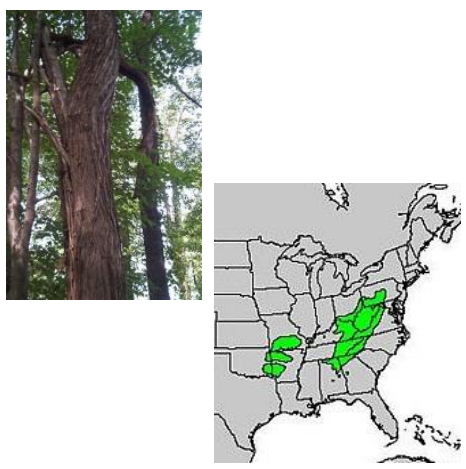

Flowers are white, 0.5 to 1 " across, fragrant, and appear in drooping 3 to 8 " racemes; fruit is a flat, brown glabrous legume, $2-4$ ", maturing in late summer and persisting into winter. ${ }^{1}$

Twigs:

Angular, brown, zigzag with stipular spines.
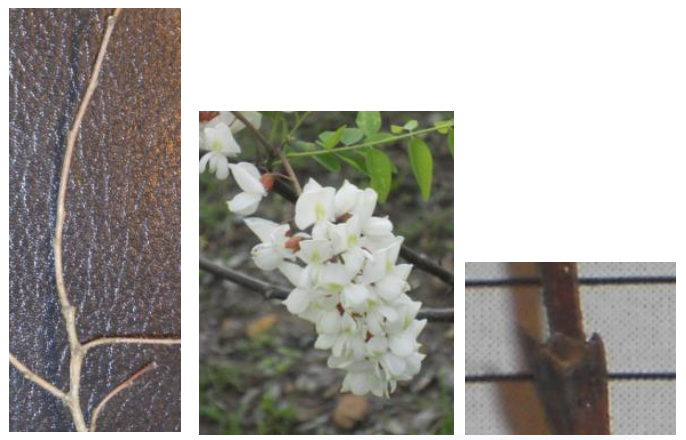

\section{Buds:}

$1 / 16^{\prime \prime}$, brown and downy, terminal absent.
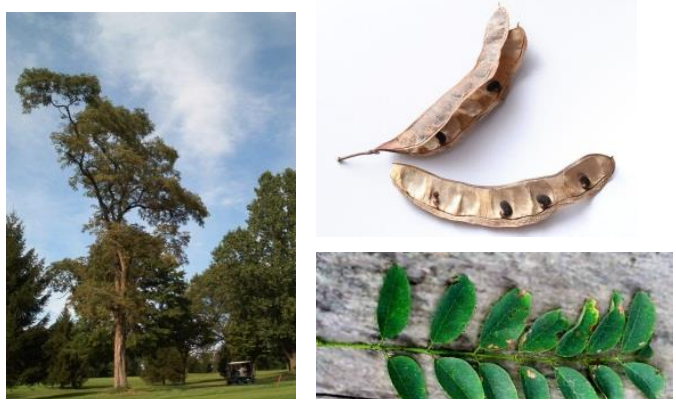

Black locust is intolerant of shade and has a rapid growth rate. It reaches a size of 60 to 80 feet and a diameter of 2 to 4 feet. The leaves may turn yellow in the fall, but often drop with no coloration. The showy, fragrant flowers appear in mid to late spring. The buds may be indented into the twigs and may not be visible. Stipular spines are generally 0.5 to 1 "long. Although Black locust has a rather small native range, it has naturalized over much of North America. It typically has an irregular crown and spreads by root sprouts. 
Honeylocust

Gleditsia triacanthos

Fabaceae

\section{Leaves:}

5 to 20 " long, alternate, both pinnately and bipinnately compound,15-30 nearly sessile leaflets, leaflets are 0.5 to 1.5 " long, dark green; deciduous.
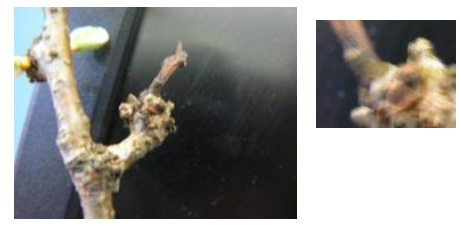

Flowers/Fruit:

Flowers are small, greenish, and borne in 2 to 3 " long raceme; fruit is a reddish to brownish twisted legume 7-18" long.
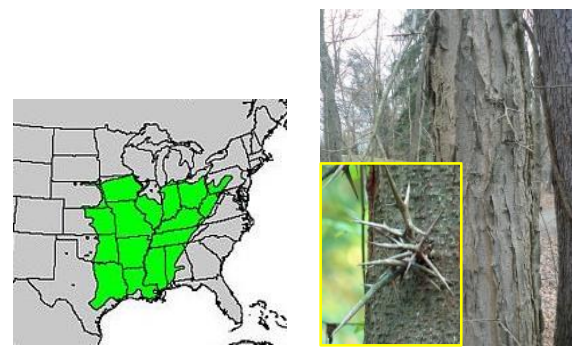

\section{Twigs:}

Twigs are zigzag, greenish-brown, smooth.

\section{Buds:}

Small, greyish may be naked or have scales.

Honeylocust is intolerant of shade and has a rapid growth rate. It reaches a height of 70 to 80 feet and a diameter of 2 to 3 feet. Typically, both pinnately and bipinnately compound leaves appear on the same tree. Leaves turn yellow in the fall. The flowers, although inconspicuous, are fragrant and appear in mid spring. Fruits mature in the late summer to fall. Honeylocust lacks terminal buds. Ridges of bark often peel away from the trunk. Both twigs and bark have 1 to 4 " long, branched thorns. Crown shape is generally flat-topped to irregular, sometimes rounded. 
Flowering dogwood

Cornus florida

\section{Cornaceae}

\section{Leaves:}

2.5 to 6 "long, opposite, oval, dark green, glabrous above, acuminate, margins wavy, 6 to 7 pairs of conspicuous veins; deciduous.

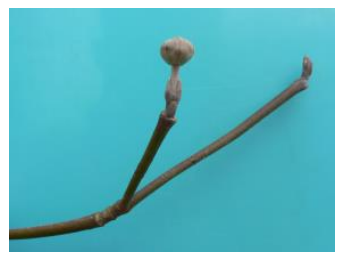

\section{Flowers/Fruit:}

Flowers are $1 / 4$ " wide, greenish to yellow, and in clusters; fruit is $1 / 4$ to $1 / 2$ " through, a shiny, bright red drupe, appearing in clusters of 2 to 4 in late summer to fall.

\section{Twigs:}

Slender, purplish with a glaucous coating.
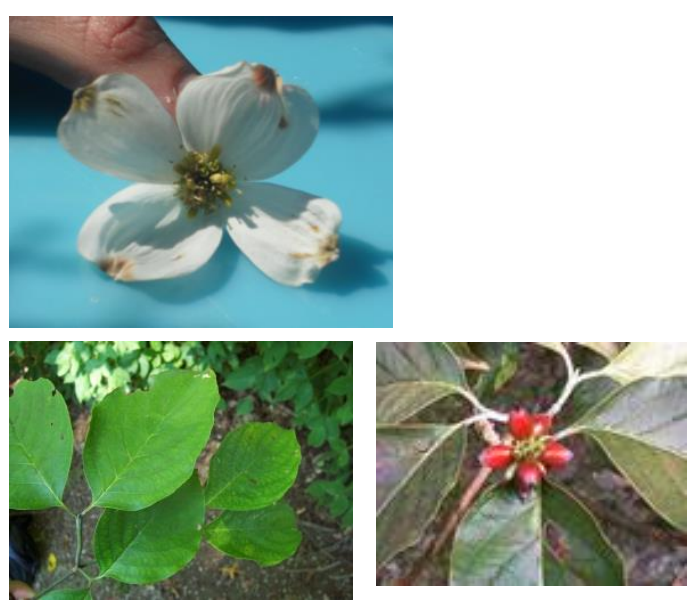

\section{Buds:}

Flower buds globose; leaf buds acute.
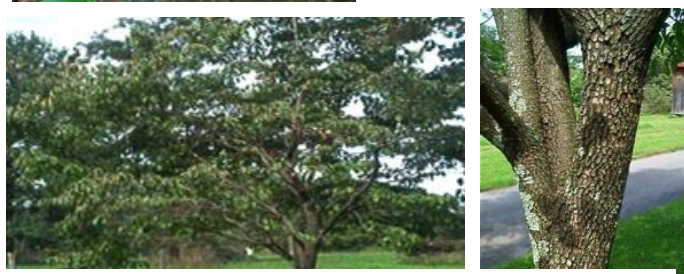

Flowering dogwood is tolerant of shade and has a medium growth rate. It reaches a height of 15 to 40 feet and a diameter of 0.5 to 1.5 feet. Leaves usually turn red in the fall, but may turn yellow to orange. The flowers themselves are not showy, it is the 4 white to pink, 1.5 to 2 "long, bracts that catch the attention of passersby. Flowers appear in mid spring. Both flower and leaf buds are greyish to purple; leaf buds opposite and valvate. Bark is smooth when young. Often used as an ornamental. Crown is usually flat-topped. 


\section{Blackgum, Black tupelo}

Nyssa sylvatica

Nyssaceae

\section{Leaves:}

Alternate, simple, 4-6" long, shiny, dark green, entire, infrequently one or two large marginal teeth on distal half; deciduous.

\section{Flowers/Fruit:}

Flowers are small, greenish, and appear in mid spring; fruit is a drupe, dark blue to black, $1 / 3$ to $2 / 3$ ", up to 3 drupes on a stalk, maturing in late summer.

\section{Twigs:}

Twigs are slender, greyish brown, glabrous with diaphragmed pith.

\section{Buds:}

$1 / 8$ to $1 / 4 "$, yellow-brown, scales brownish at ends.
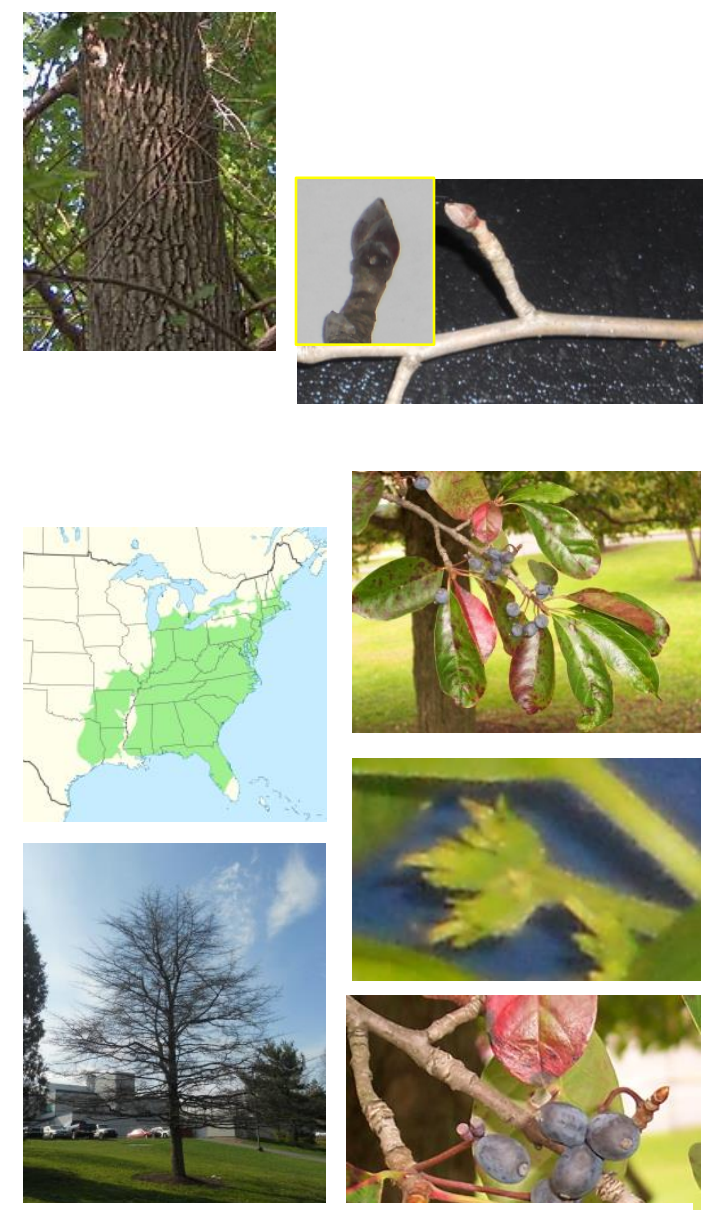

Blackgum is tolerant of shade and has a rapid growth rate on good sites. It reaches a height of 60 to 90 feet and a diameter of 2 to 3 feet. The leaves turn yellow, orange, to red in the fall. Small branches have many small spur-like twigs present. Blackgum generally has a conical crown when young, but becomes irregular to flat-topped with age. Blackgum will grow on many different sites. It has little timber value. Used as an ornamental. 


\section{Water tupelo}

Nyssa aquatica

Nyssaceae

\section{Leaves:}

5-7" long, 2-4" wide, alternate, margin entire, acuminate, dark green above, paler and downy below; deciduous. ${ }^{1}$

\section{Flowers/Fruit:}

Flowers are greenish, small, and appear in early spring; fruits are 1", pendent on slender stalks, reddish purple, a ridged nutlet inside.

\section{Twigs:}

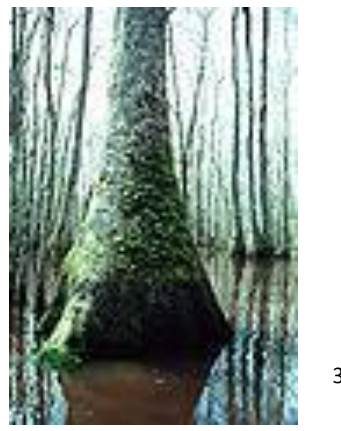

Twigs are stout, reddish brown.

\section{Buds:}

To $1 / 4$, yellowish, terminals rounded, laterals smaller and not conspicuous.

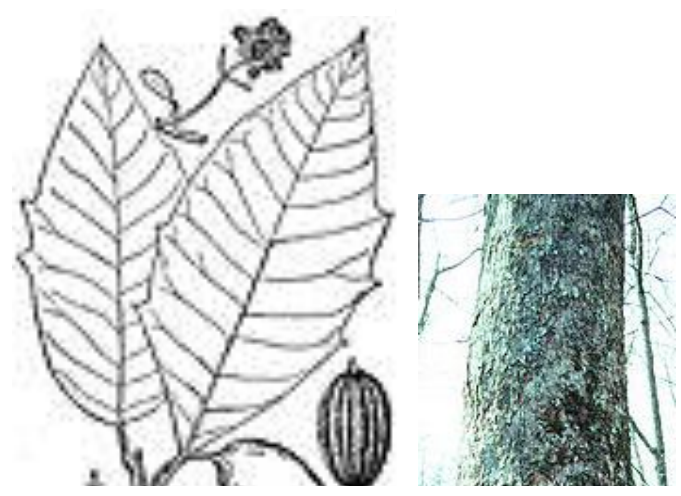

Water tupelo is intolerant of shade and has a rapid growth rate. It reaches a height of 80 to 100 feet and a diameter of 3 to 4 feet. Trunks have a swollen base that tapers up to a long, clear bole, and its root system is periodically under water, due to its habitat preference of floodplains. The leaves may have a few teeth along the margin and turn yellow in the fall. Small branches have spur-like twigs. Crown shape is narrow. Water tupelo is used for timber. It will tolerate heavily flooded soils and inhabits swamps. 


\section{American holly}

Ilex opaca

Aquifoliaceae

\section{Leaves:}

2 to 4 " long, thick, leathery, dark green, spine toothed, elliptic; evergreen.

\section{Flowers/Fruit:}

The flowers are small, greenish white, and appear in late spring; fruits is $1 / 4$ " through, a bright red drupe, matures in the fall and persists through the winter.

\section{Twigs:}

Twigs are grayish to light brown, smooth.

\section{Buds:}

Very small, $1 / 8$ to $1 / 16^{\prime \prime}$ long, gray, and pubescent.
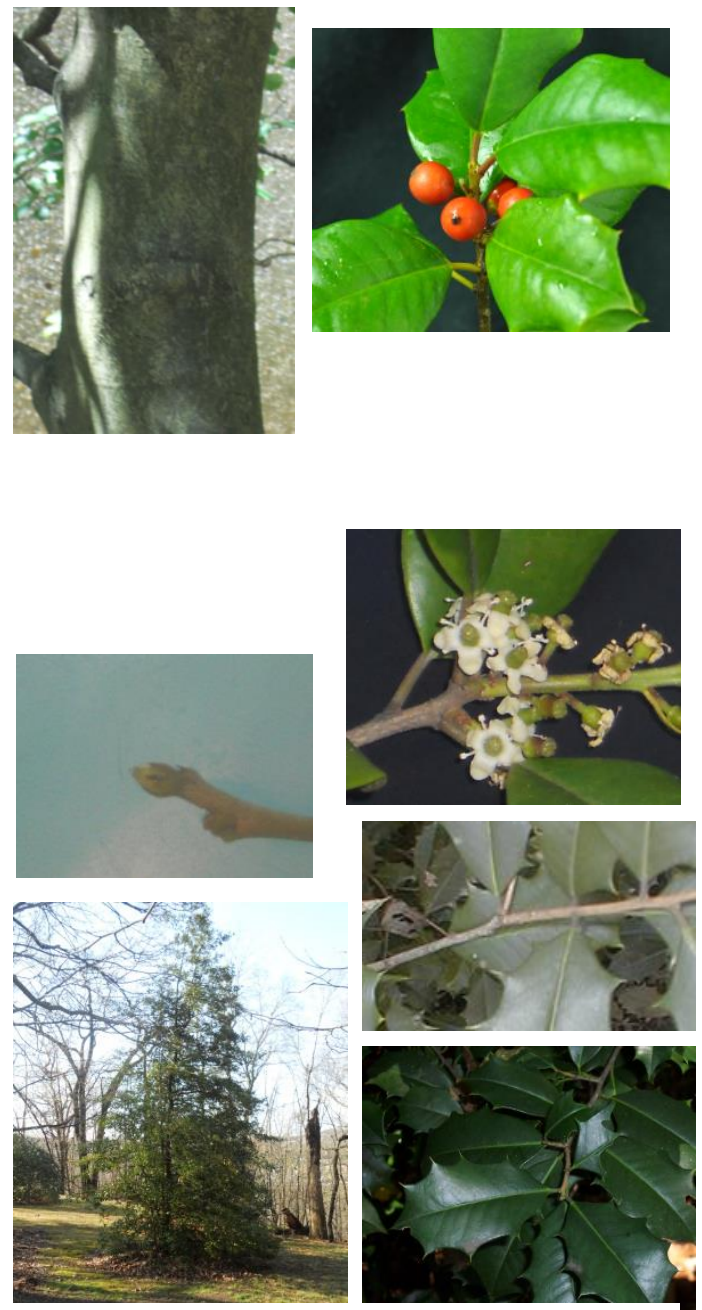

American holly is tolerant of shade and has a slow to moderate growth rate. It reaches a height of 40 to 50 feet and a diameter of 1 to 2 feet. Leaves are evergreen, previous year's leaves drop each spring as new foliage emerges. Flowers are dioecious. Twigs have noticeable, but small lenticels. American holly has a dense, pyramidal crown in the open and an irregular crown in the forest. It will grow on a variety sites, but frequently grows on gravely sites. It is often used as an ornamental and is the state tree of Delaware. 
Red maple

Acer rubrum

Aceraceae

\section{Leaves:}

Orbicular, 3 to 6" across, opposite, palmately 3-5 lobed (usually 3 ), margin serrate, light green above, white below; deciduous.

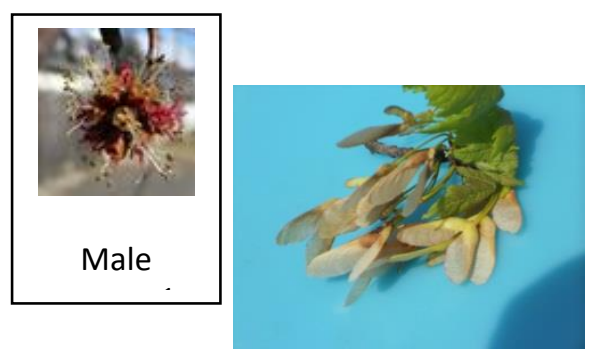

\section{Flowers/Fruit:}

Flowers are green to yellow, to red, 5 petals; fruit is a double samara, matures late spring, wings $3 / 4$ " long, greenish to reddish brown when mature.

\section{Twigs:}

Slender, dark red, lustrous, minute lenticels.

\section{Buds:}

To $1 / 4$, blunt and greenish to reddish in color; flower

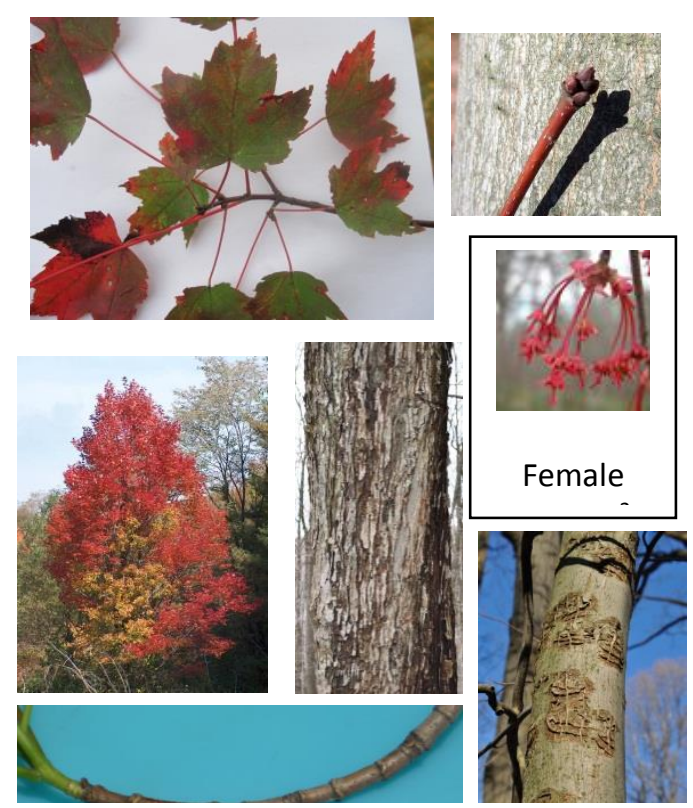

Red maple is intermediate in shade-tolerance and has a rapid growth rate. It reaches a height of 75 to 90 feet and a diameter of 1 to 3 feet. The leaves turn various shades of yellow, orange, and red in the fall. Flowers appear before the leaves in very early spring. The fruits are strongly V-shaped. Red maple is the most common and widespread tree throughout the eastern United States. Red maple is commonly planted as an ornamental and many cultivars exist. It is also used for timber and is marketed as soft maple. 
Silver maple

Acer saccharinum

Aceraceae

\section{Leaves:}

Opposite, 5 to 7" across, P. 82 deeply palmately 5lobed, margin serrate, pale green above, silvery underneath; deciduous.

\section{Flowers/Fruit:}

Flowers are brownish red ${ }^{1}$; fruit is a double samara,

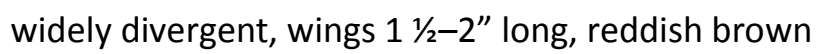
when mature.

\section{Twigs:}

Twigs are red to brown, have fetid odor, lenticellate.
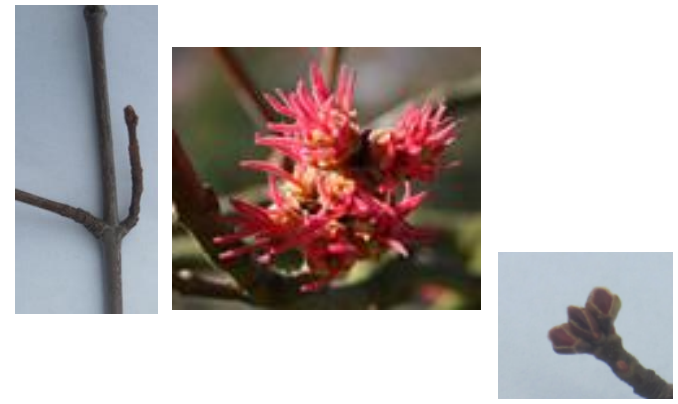

Buds:

To $1 / 4 "$ long, narrow to rounded, red in color.
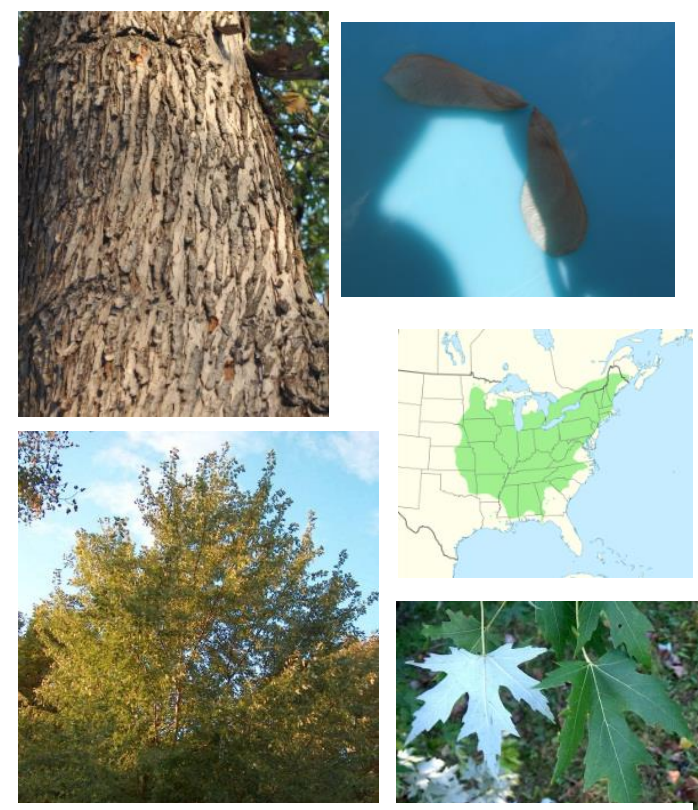

Silver maple is intolerant of shade and has a rapid growth rate. It reaches a height of 60 to 80 feet and a diameter of 2 to 4 feet. The deciduous leaves generally turn yellow in the fall. The flowers appear in very early spring, well before the leaves. Flower buds are noticeably larger than leaf buds. The fruits mature in the late spring. Silver maple has a rounded to vase shaped crown and a trunk that often splits into multiple stems not far above the ground. It has been overused as an ornamental and will tolerate a wide array of growing conditions, preferring wetlands. 
Boxelder

Acer negundo

Aceraceae

\section{Leaves:}

5 to 7" long, opposite, pinnately compound with 3-7 leaflets, variable size and shape, light to dark green, margin coarsely serrate or lobed; deciduous.

\section{Flowers/Fruit:}

Flowers are yellow green; fruit is a double samara, slightly convergent wings, $1-1.5^{\prime \prime}$ long, yellow brown when mature.

\section{Twigs:}

Stout, green to purplish green, lenticellate.

\section{Buds:}

To $1 / 8$ ", ovoid, 4 visible bluish white tomentose scales.
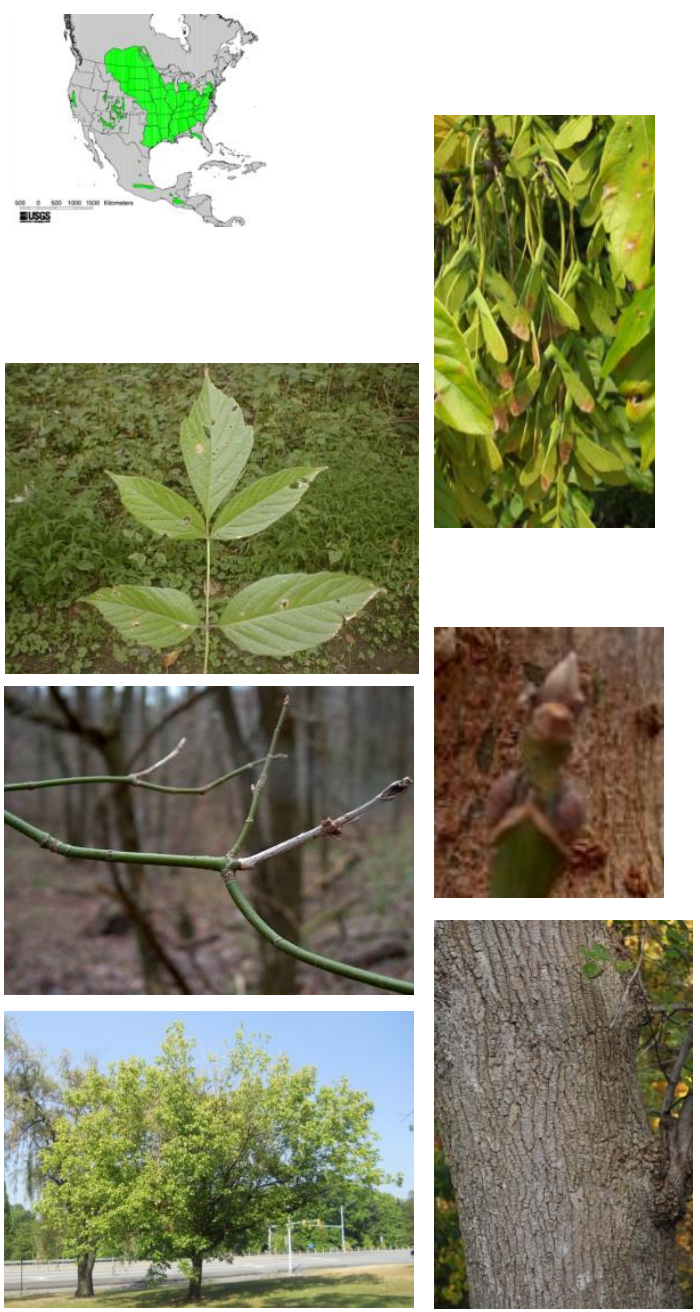

Boxelder is tolerant of shade and has a rapid growth rate. It grows to a height of 50 to 75 feet and a diameter of 2 to 4 feet. The leaves turn yellow in the fall, but often drop without turning color. The fruits, which appear in clusters, mature in late summer and persist into the winter. Flowers are dioecious and appear in early spring. Twigs are smooth, emit a foul odor when broken and are often shiny. Boxelder has a rounded crown and a short trunk. It will tolerate adverse growing conditions and is often regarded as a weed. 
Sugar maple

Acer saccharum

Aceraceae

\section{Leaves:}

3 to 6" across, opposite, palmately 5-lobed, margins of

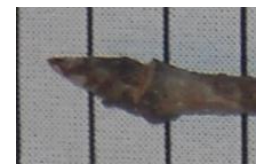
lobes entire, bright green above, pale and smooth below; deciduous.

\section{Flowers/Fruit:}

Flowers are greenish yellow; fruit is a double samara, 1 " long wings, reddish to yellowish brown, matures in fall.

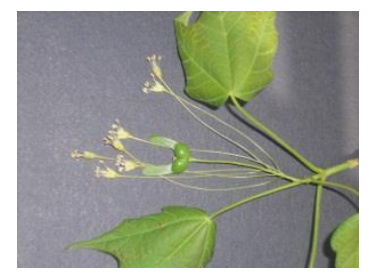

\section{Twigs:}

Twigs are shiny, brownish, and lenticellate.

\section{Buds:}

To $1 / 4$ " long, brown, acute, and sharply pointed.
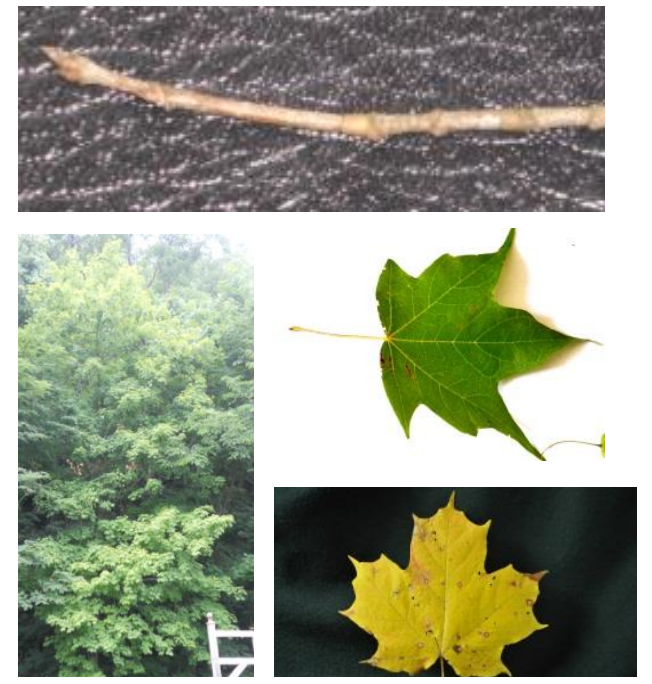

Sugar maple is extremely tolerant of shade, and has a moderate growth rate. It reaches a height of 75 to 100 feet and a diameter of 2 to 4 feet. The leaves turn various shades of yellow, orange, and red in the autumn. Flowers are borne on long stalks in drooping clusters and appear with the leaves in the spring. The wings of the fruits are parallel to only slightly divergent. Sugar maple has a rounded to oval shaped crown. It generally grows best on cool, moist, but well drained sites. It is used for timber, ornamental purposes, and syrup. 


\section{Staghorn sumac}

\section{Rhus typhina}

Anacardiaceae

\section{Leaves:}

12 to 24 " long, alternate, pinnately compound, 11-31 leaflets, leaflets 2 to 4 " long, margin coarsely serrate, green above, greyish beneath, pubescent rachis; deciduous.

\section{Flowers/Fruit:}
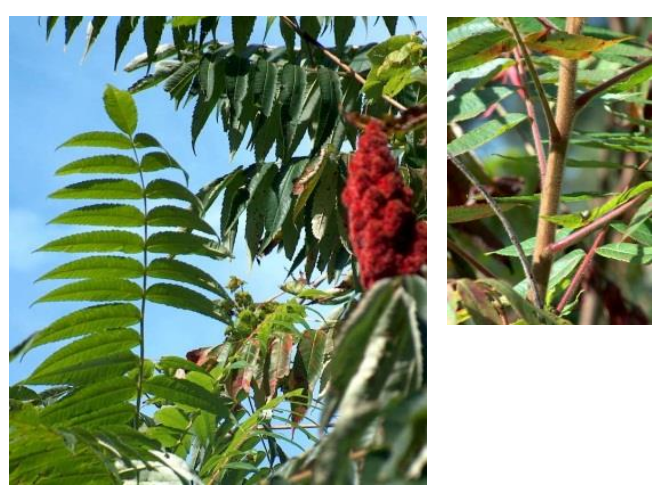

Flowers are greenish white, $1 / 8^{\prime \prime}$ across, and borne in upright, 6 to 8 " long clusters; fruits are small, hairy, red drupes born in upright, 6 to 8 " long, compact, cone-shaped dense clusters.

\section{Twigs:}

Twigs are very hairy, stout, and brown.

\section{Buds:}

Hairy, white, surrounded by U-shaped leaf scar.
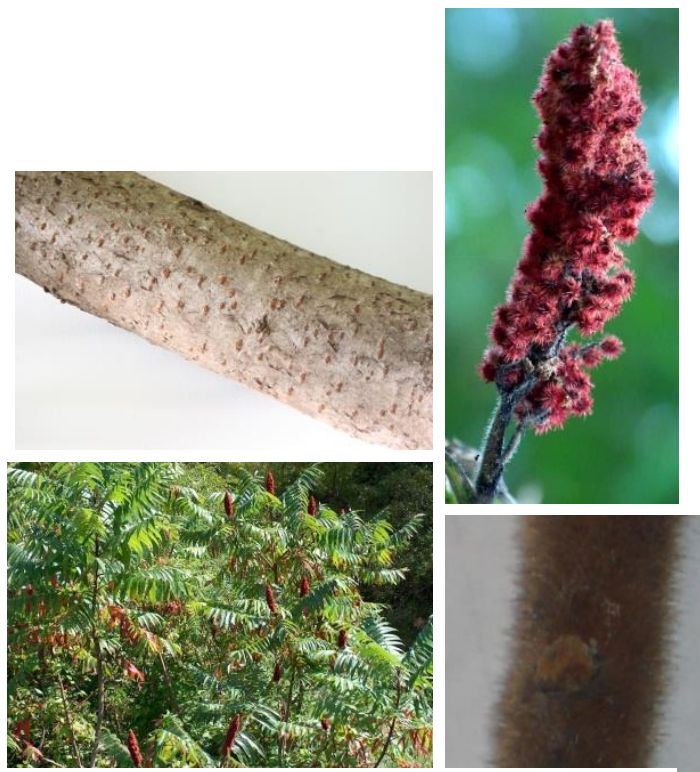

Staghorn sumac is intolerant of shade and has a rapid growth rate. It reaches a height of 25 to 35 feet and a diameter of 6 to 12". The leaves turn various shades of yellow, orange, and red in the fall. Flowers are dioecious. The fruits persist through the winter. Twigs and leaves emit a white sap when bruised. Terminal buds are absent. Bark becomes scaly with age. Staghorn sumac is a short lived plant that typically inhabits disturbed sites, fields, etc. It is used as an ornamental. Beware of a related plant-poison sumac. 
Yellow buckeye

Aesculus flava

Hippocastanaceae

\section{Leaves:}

8 to 14 " long, P. 91 opposite, palmately compound, 5 leaflets, leaflets 4 to 7 " long, serrated, elliptical, smooth, dark green; deciduous.

\section{Flowers/Fruit:}

Flowers are whitish yellow, and appear in upright, 5 to 7" long clusters; fruits are 1 to 2", P. 93 a brown capsule, smooth husk covering seed.

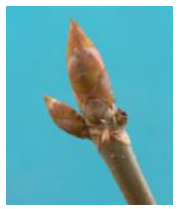

\section{Twigs:}

Twigs are stout, brownish grey, and have large leaf scars.

\section{Buds:}

To $2 / 3^{\prime \prime}$, non-resinous, brown.
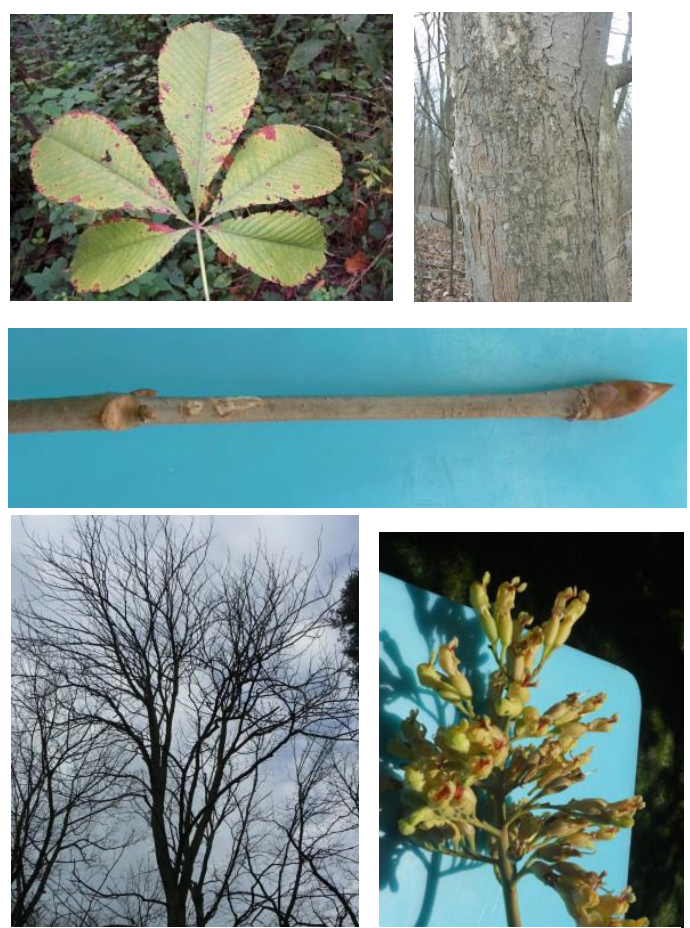

Yellow buckeye is intermediate in shade-tolerance and has a rapid growth rate. It reaches a height of 60 to 90 feet and a diameter of 2 to 3 feet. The leaves drop very early in the fall and turn yellowish. Often, the leaves drop in late summer, due to disease, and turn no significant color. Leaves and twigs lack the fetid odor of Ohio buckeye. The flowers appear in the spring after the leaves and have stamens shorter than the petals. Yellow buckeye prefers moist sites. It has an oval to rounded crown. 
White ash

Fraxinus americana

Oleaceae

\section{Leaves:}

7 to 14 " long, opposite, pinnately compound; 5-9 leaflets, leaflets 2 to 5 " long, ovate or elliptical, dark

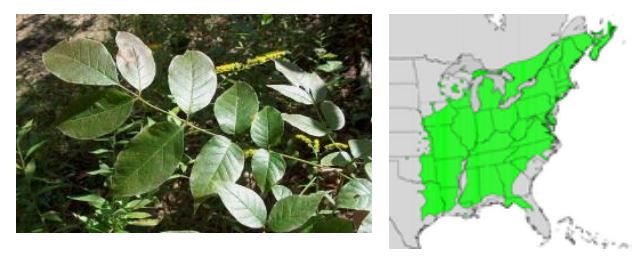
green, margin serrate or entire; deciduous.

\section{Flowers/Fruit:}

Flowers are green to brownish purple, in panicles; fruits are a lanceolate samara, 1-2", wing not greatly narrowed at seed cavity, yellowish brown.

\section{Twigs:}

Twigs are stout, dark green to gray-green.

\section{Buds:}

To $1 / 4$ " ovoid, with 4-6 brownish scales.
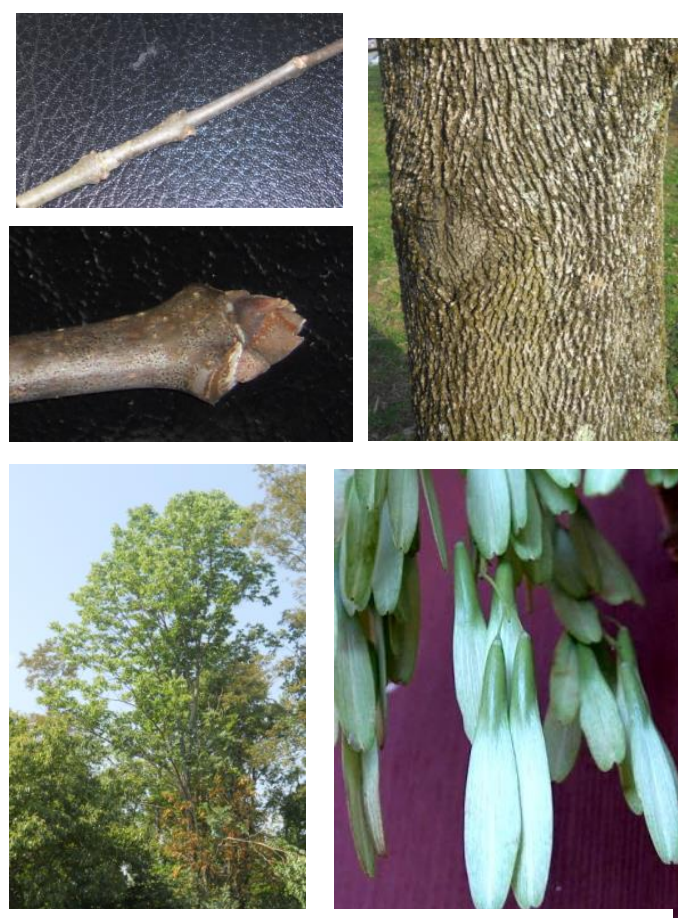

White ash is intermediate in shade-tolerance and has a rapid growth rate. It reaches a height of 75 to 90 feet and a diameter of 2 to 3 feet. Leaves are greyish on the undersides and turn shades of yellow, orange, red, and purple in the fall. Leaflets are stalked on the rachis. Flowers are dioecious and appear in the spring. Fruits are borne in drooping clusters and mature in the fall. Twigs are lenticellate with numerous bundle scars. Lateral buds are inserted in the $V$ notch of a shield-shaped leaf scar. It has a rounded to oval crown. 
Green ash

Fraxinus pennsylvanica

Oleaceae

\section{Leaves:}

6 to 11 " long, opposite, pinnately compound; 7-9

leaflets, leaflets 2 to 6 " long, stalked, ovate or

elliptical, margin serrate or entire, shiny, yellow-green

above, pale below; deciduous.

\section{Flowers/Fruit:}

Flowers are green to purplish; fruit is a narrowly lanceolate samara, 1-2", wing narrowed toward seed cavity, yellowish brown.

\section{Twigs:}

Stout, flattened at nodes, gray to greenish brown.
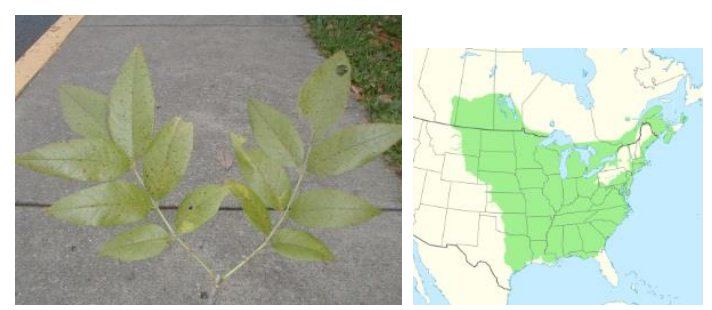

\section{Buds:}

To $1 / 4 "$, conical to ovate, rusty brown, pubescent; lateral bud on top of straight-topped leaf scar.

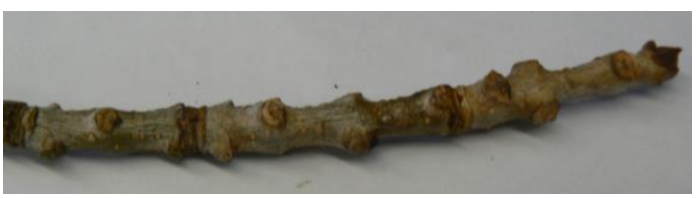

lateral bud on top of straight-topped leaf scar.

Green ash is intolerant of shade and has an intermediate growth rate. It reaches a height of 60 to 80 feet and a diameter of 2 to 3 feet. The leaves turn yellow in the fall. Flowers are dioecious, are borne in panicles, and appear in the spring. Fruits are born in drooping clusters and mature in the fall. Bark is not as deeply furrowed as White ash. Green ash grows best on wet sites, but will tolerate adverse growing conditions. It has a rounded to oval crown and has been heavily used as an ornamental. 